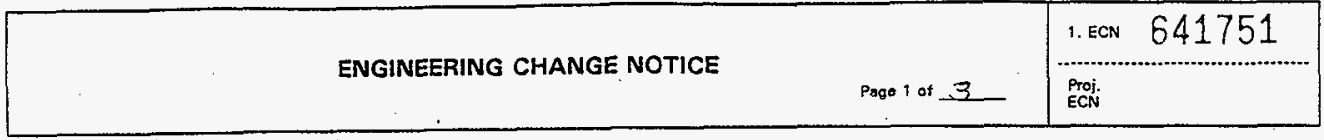

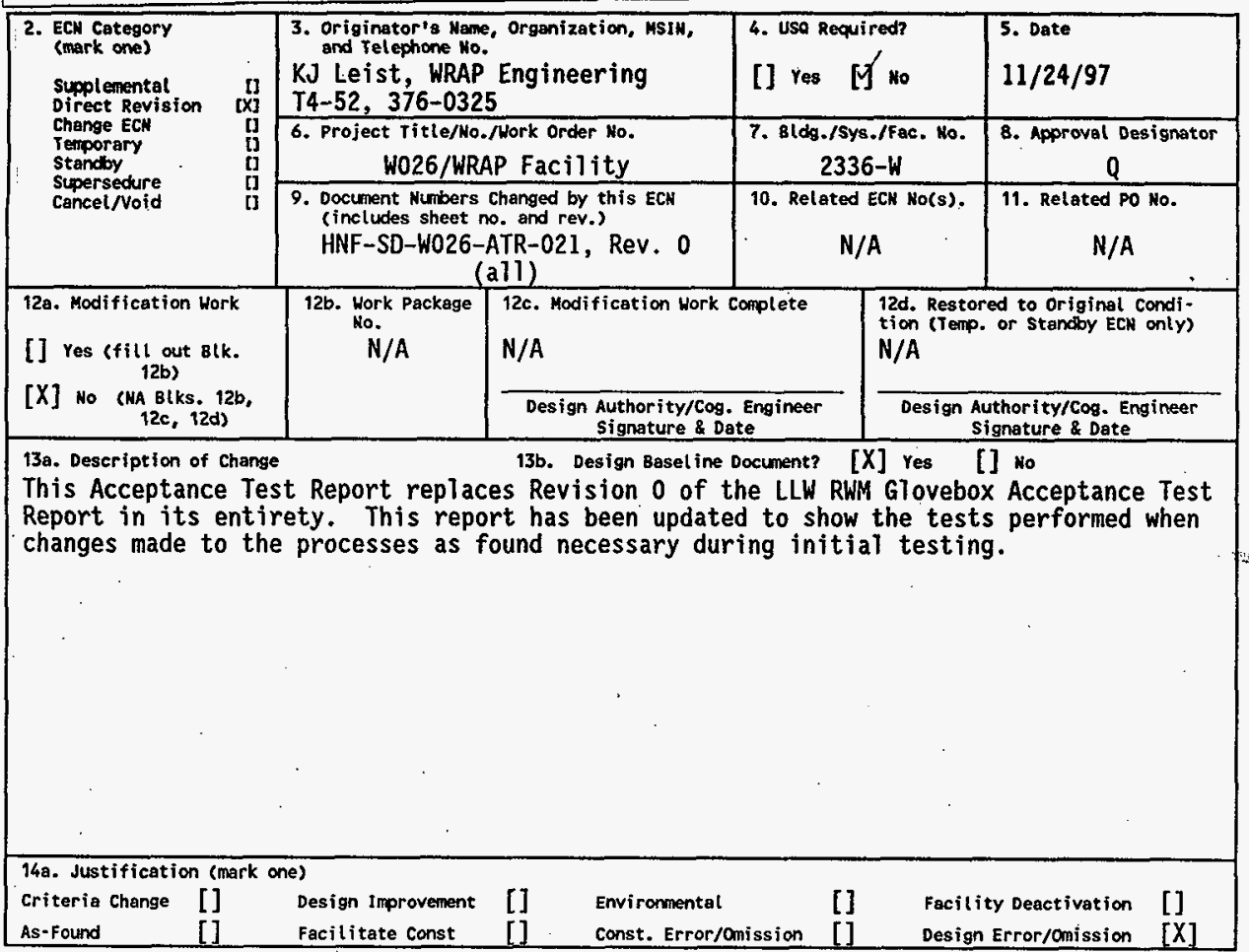

14b. Justification Details

The changes to the initial report were driven by construction errors, design deficiencies, and enhancements (standardization).

15. Distribution (include name, MSIN, and no. of copies)

See attached distribution sheet.

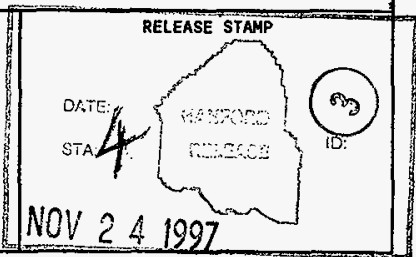

A-7900-013-2 (05/96) GEF095 


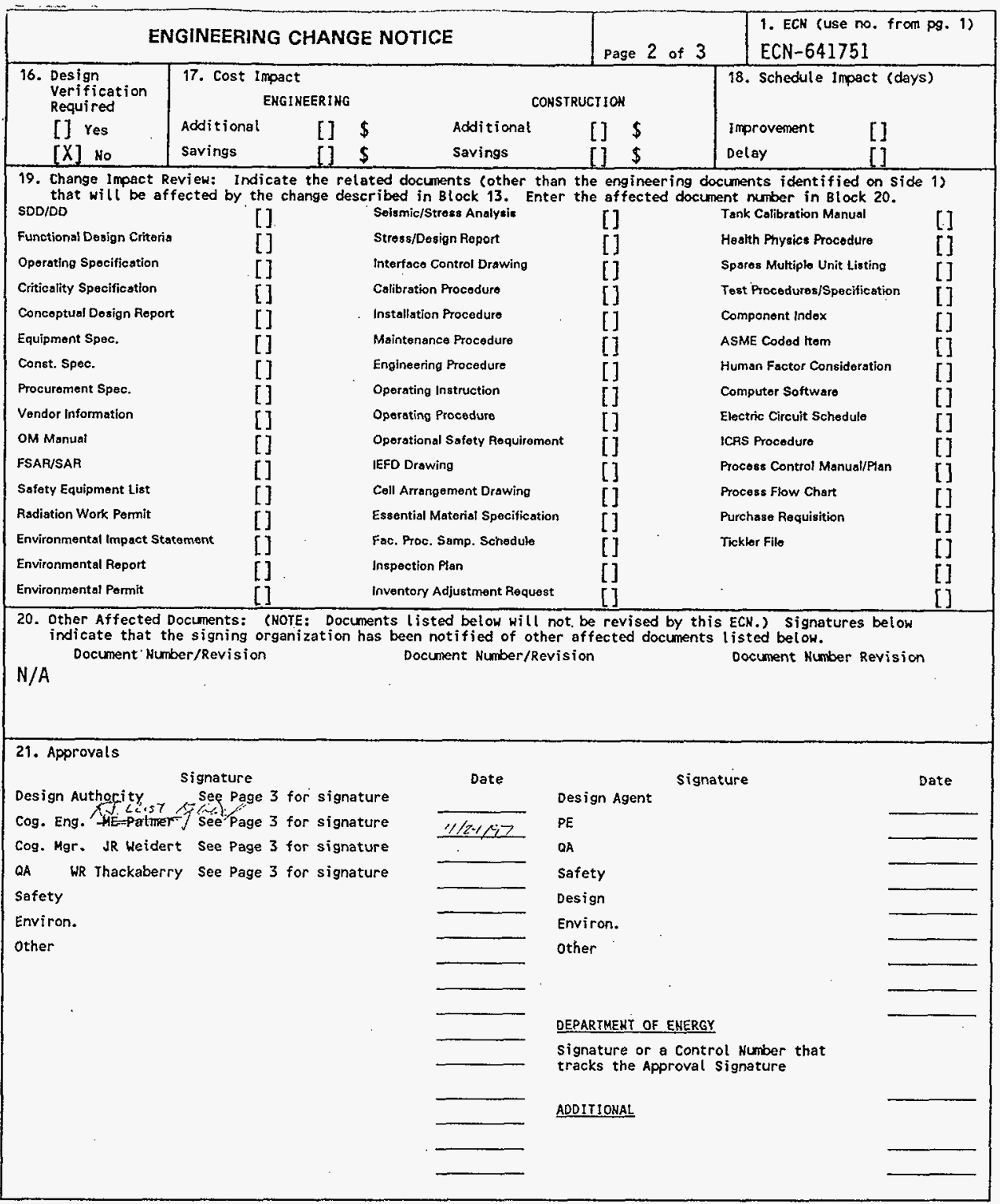




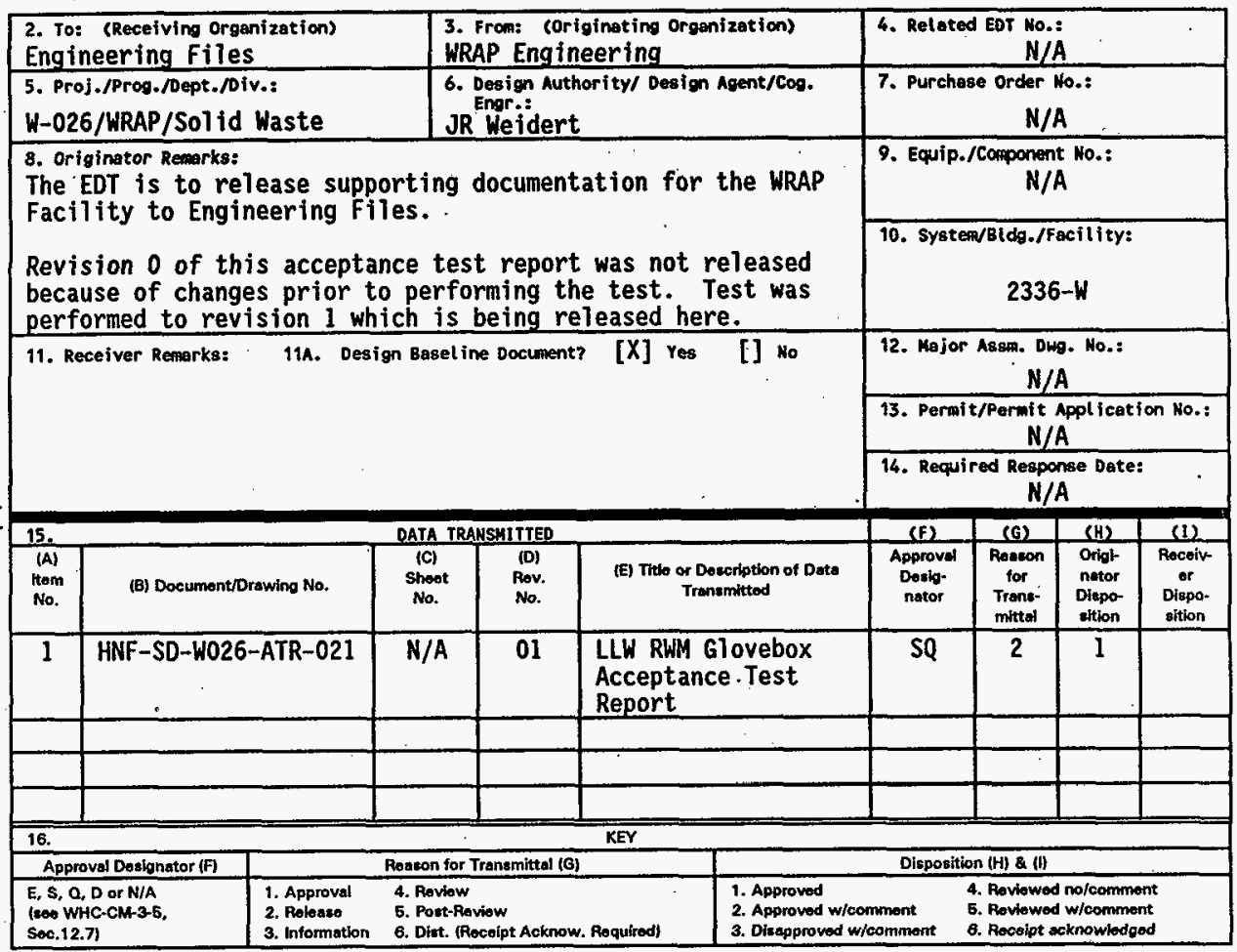

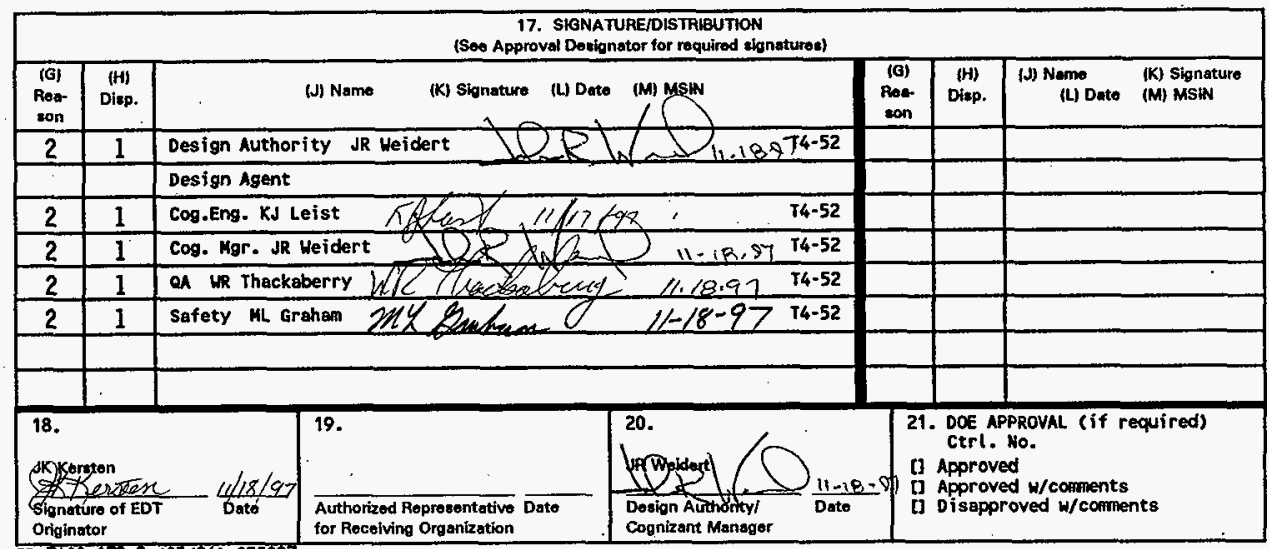




\section{WRAP LOW LEVEL WASTE RESTRICTED. WASTE MANAGEMENT (LLW RWM) GLOVEBOX ACCEPTANCE TEST REPORT}

\section{KJ Leist}

Waste Management Federal Services of Hanford, Richland, WA 99352

U.S. Department of Energy Contract DE-ACO6-96RL13200

$$
\begin{aligned}
& \text { EDT/ECN: EDT-620625 } \\
& \text { Org Code: } 32620 \text { Win Charge Code: A2E10 } 265 \\
& \text { B\&R Code: EW3130020 Total Pages: } 266 \text { 224 } 11 / 21 / 47
\end{aligned}
$$

Key Words: W-026, ATR, Drum, Diversified Metal Products

Abstract: The primary focus of the glovebox acceptance test was to examine control system interlocks, display menus, alarms, and operator messages. Limited mechanical testing involving the drum ports and hoist were also conducted.

* FESTO is a registered trademark of Festo KG, Federal Republic of Germany.

* EXCEL is a registered trademark of Microsoft Corporation, Redmond, WA.

* Allen-Bradley is a registered trademark of the Allen-Bradley Company, Inc., Milwaukee, WI.

* WinLogic 5 is a registered trademark of Rockwe1l Software, West Allis, WI

IRADEMARK DISCLAIMER. Reference herein to any specific comercial product, process, or service by trade name, trademark, manufacturer, or otherwise, does not necessarily constitute or imply its endorsement, recomendation, or favoring by the United States Goverment or any agency thereof or its contractors or subcontractors.

Printed in the United States of America. To obtain copies of this document, contact: Document control Services, P.O. Box 950, Mailstop H6-08, Richland WA 99352, Phone (509) 372-2420; Fax $(509) 376-4989$.
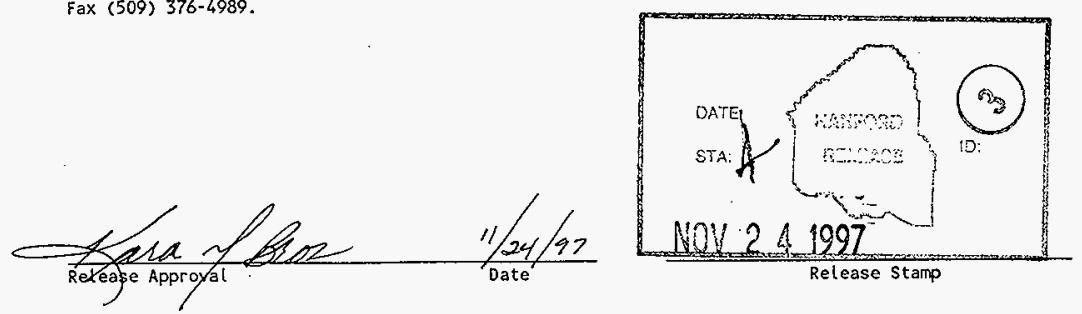
(2) Titte

WRAP LLW RWM Glovebox Acceptance Test Report

CHANGE CONTROL RECORD

(3) Revision (4) Description of Change - Replace, Add, and Delete Pages

(7) Initial Release Rev. 0, dated 04/21/97 on EDT-161643

1 RS Complete Revision to Document per ECN641751

Authorized for Release

(5) Cog. Engr. (6) Cog. Mgr. Date

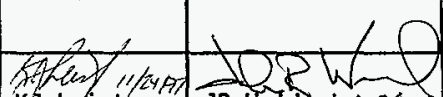


HNF-SD-W026-ATR-021, Rev. 1

ACCEPTANCE TEST REPORT

WRAP MODULE I

LLW RWM GLOVEBOX ACCEPTANCE TEST PROCEDURE

$13027 \mathrm{~A}-87$

\section{ABSTRACT:}

On April 22, 1997, the Low Level Waste Restricted Waste Management (LLW RWM) glovebox was tested using glovebox acceptance test procedure 13027A-87.

The primary focus of the glovebox acceptance test was to examine control system interlocks, display menus, alarms, and operator messages. Limited mechanical testing involving the drum ports and hoist was also conducted.

As of November 12, 1997, 11 of the 47 test exceptions that affect the LLW RWM glovebox remain open. These items will be tracked and closed via the WRAP Master Test Exception Database.

As part of Test Exception resolution/closure the responsible individual closing the Test Exception performs a retest of the affected item(s) to ensure the identified deficiency is corrected, and, or to test items not previously available to support testing. Test Exceptions are provided as appendices to this report. 
WASTE MANAGEMENT HANFORD COMPANY HNF-SD-W026-ATR-021, Rev. 1 PROJECT W-026, WRAP I

ACCEPTANCE TEST REPORT (13027A-87) - LLW RWM ACCEPTANCE TEST

TABLE OF CONTENTS

INTRODUCTION $\ldots \ldots \ldots \ldots \ldots \ldots \ldots \ldots \ldots \ldots \ldots \ldots \ldots \ldots \ldots \ldots$ DESCRIPTION OF TEST, TEST METHOD AND TEST EQUIPMENT $\ldots \ldots \ldots \ldots \ldots \ldots \ldots$

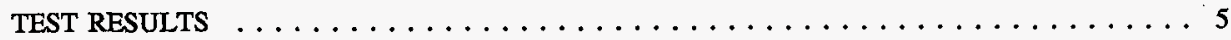
CONCLUSION AND RECOMMENDATIONS $\ldots \ldots \ldots \ldots \ldots \ldots \ldots \ldots \ldots \ldots$ APPENDICES $\ldots \ldots \ldots \ldots \ldots \ldots \ldots \ldots \ldots \ldots \ldots \ldots \ldots \ldots \ldots$ Appendix A - LLW RWM Glovebox Test Exception Sign-Off Sheets . . . . . . . . . A-1 


\section{INTRODDCTION}

On April 22, 1997, the Low Level Waste Restricted Waste Management (LLW RWM) glovebox was tested using acceptance test procedure 13027A-87. Mr. Robert L. Warmenhoven served as test director, $\mathrm{Mr}$. Kendrick Leist acted as test operator and test witness, and Michael Lane provided miscellaneous software support.

The primary focus of the glovebox acceptance test was to examine glovebox control system interlocks, operator Interface Unit (OIU) menus, alarms, and messages. Basic drum port and lift table control sequences were demonstrated. OIU menus, messages, and alarm sequences were examined, with few exceptions noted. Barcode testing was bypassed, due to the lack of installed equipment as well as the switch from basic reliance on fixed bar code readers to the enhanced use of portable bar code readers. Bar code testing was completed during performance of the ILW RWM OTP.

Mechanical and control deficiencies were documented as Test Exceptions during performance of this Acceptance Test. These items are attached as Appendix $A$ to this report. 


\section{DESCRIPTIOY OF TEST, TEST METHOD AND TEST EQUIPMENT}

Testing was conducted on the ILW RWM Glovebox using acceptance test procedure 13027A-87. This test procedure is designed to meet Project $W-026$ specification Section 13027 and specification section 13462 test requirements.

A list of $\backslash$ the items to be tested and the equipment required to support testing is provided. One of the primary items used to support testing is a notebook computer configured with winLogic 5 by Rockwell Software, Rev. 3.04, Serial Number WL5-15707-C. This software allows control system ladder logic and glovebox switch and sensor activation to be continuously monitored during testing.

A checkout sheet is provided to review and verify glovebox sensor and switch operation prior to testing. A setup section is provided to list the initial actions and conditions required prior to initiating testing. Included in this section is an overview of test methods and conventions. Due to prior, informal checkout of the glovebox equipment, the checkout sheet was not utilized.

The body of the test procedure is divided into "test cases". Each test case is designed to test a single feature or set of features, such as an alarm or an alarm/interlock combination, which are specification requirements. Each test case is written in step-wise fashion with blocks provided to allow the test witness to indicate "pass" or "fail" status for each test step. A "test exception" should be generated for each step that fails.

TEST DEVIATIONS/CHANGES

Several test procedure clerical errors were noted during testing. Each clerical error was noted in the body of the test procedure and was corrected via line through, record change, initial and date by the individual making the change.

For each step that failed (e.g., not due to clerical error), a test Exception was generated. 


\section{TEST REgULTS}

A total of 32 Test Exceptions were identified during performance of the LLW RWM Acceptance Test. Additionally another 15 Test Exceptions that affect the LLW RWM glove box were identified during performance of TRU RWM, TRU and LLW Acceptance Testing.

of the 47 identified Test Exceptions that affect LLW RWM, 36 have been retested and closed. There are 11 Test Exceptions that remain open. The open Test Exceptions that affect LLW RWM glove box are listed below with a brief description of the deficiency, recommended corrective action, status and required completion for closure.

TE \#005 Entry/Exit port lid in position sensor activation is not repeatable.

Corrective action: E/E port lid in position sensors changed from inductive to capacitive type sensor. Work complete, sensor adjustment and lift table reprograming need to performed. This work on hold until E/E port vacuum cup modification is complete.

This TE must be closed prior to Hot operation.

TE \#029 Local E-Stop not tested for Maintenance mode operation, was not identified as a testable item on the ATP.

Corrective action: Test Maintenance mode local E-stop operation for the LLW RWM glove box.

This TE must be closed prior to Hot operation.

TE \#036 BTP, E/E port and one trip ports - E-Stop does not stop port from raising or lowering.

Corrective action: Replace 2 position control valve with 3 position, pressurized center valve and make associated software changes for BTP, E/E port and one trip port raise/lower control valves.

Work complete on E/E port and one trip ports. BTP's on hold until software can be modified, replacement valves are on hand and will be replaced when software is modified.

This TE does not have to be closed until after Hot Operation. Does not affect operation of the BTP. 
TEST RESULTS continued

TE \#37 Generic issue that applies to all lift tables. Lift table lowers with no control request for movement. Cause unknown.

Corrective action: Troubleshoot and develop action plan based on findings. Lift table may be operated in maintenance mode only with serial communication loop disabled. Auto control of lift table(s) is not possible until this issue is resolved. E/E ports would also have to be operated in maintenance mode. POP revisions must be implemented to allow glove box operation in this manner. This is a temporary $f i x$ only.

Long term solution will be based on results of troubleshooting and recommendations from Vendor/COG Engineer.

This TE must be resolved prior to Hot Operation.

TE \#105 E/E Port - inadequate sealing surface between outer vacuum seal and drum lid results in excessive cycling vacuum generator, loss of vacuum on lid, unable to establish adequate vacuum to allow auto sequence to continue and frequent alarms. corrective action: Remove inner vacuum seal and replace with vacuum cups similar design on one trip ports. Modification in progress, need to complete and perform required retest.

This TE must be closed prior to Hot Operation.

TE \#106 Generic TE that documents the fact that control logic timer settings have not been optimized.

Corrective action: All timers are functional with initial settings documented. Optimization of timers is dependent on actual operating experience to achieve desired results. Optimize control logic timer settings during plant start up.

This TE can not be closed until the plant is operational.

TE \#137 Generic TE that documents latched control bits on maintenance mode functions.

Corrective action: Eliminate latched control bits from maintenance mode functions, such that there is no unexpected equipment movement when switching from automatic to maintenance mode and back.

This TE must be closed prior to Hot Operation. 
TE \#180 Generic TE that documents inconsistencies in implementation of Automatic to Maintenance mode transition.

Corrective action: Make all Automatic and Maintenance mode transitions consistent for all glove boxes. Work complete for LLW RWM, needs to be retested to close.

This TE must be closed prior to Hot operation.

TE \#199 Generic TE documenting inconsistencies between TRU line and LLW line lift table control logic.

Corrective action: Revise ILW line lift table control logic to be consistent with TRU line lift table control logic. Work complete on LLW RWM lift table control logic, needs to be retested to close TE.

This TE must be closed prior to Hot operation.

TE \#221 Generic TE that documents E-Stop affect on E/E port lift tables, hoist and conveyor Automatic sequences. E-Stop does not prevent sequence from starting.

Corrective action: Implement software changes that will inhibit all Automatic sequences from initiating if E-Stop activated.

This TE must be closed prior to Hot operation.

When the above listed Test Exceptions are closed the signed off original Test Exception will be incorporated into this ATR by initiation of an $\mathrm{ECN}$.

A list of test exceptions and the signed, completed test exception documents are provided as appendices to this report. 
CONCLUEION AND RECOMEGNDATIONS

1. REVIEN EQUIPYENT ITEMS USED TO SUPPORT GLOVEBOX SAMPLE BCREFNITG OPERATION

All glovebox internal equipment items including the weigh scale, bar code label dispenser, jar mill, PH analyzer, conductivity analyzer, neutralization containers, and the flammability air monitor should be carefully re-examined prior to actual use. The items specified do not appear to support glovebox operation.

2. TEBT EXCEPTION REBOLUTION

Resolve open Test Exceptions as identified in Test Results section of this ATR. 


\section{Appendix A}

LLW RWM Glovebox Test Exception sign-off sheets The 47 original test exception sign-off sheets are attached as hardcopy printouts. 
Test : $13027 \mathrm{~A}-87.12$

Step : 25

Equipment Tag \#: DO-203

Revision : 0

Date:

Specification Section : 13027A

Test Witness/Author:

LeIst

Test Operator:

\begin{tabular}{ll} 
Responsible Company: & WMH \\
\hline Responsible Subcontractor: & \\
\hline Responsible Individual: & Leist \\
\hline
\end{tabular}

Exception Description :

While testing DO-202, the pressure switch for DO-203 finally activated, (we reduced HVAC seal pressure). In forcing off this alarm bit, the door closed automatically. It stopped at the point when the Lift Table would begin lowering the table. HVAC seal pressurized centering devices extended.

\section{Exception Disposition :}

Adjusted pressure to $10 \mathrm{psig}$ on DO-202, DO-203. Sun River to adjust switch to 5 psig - Done

\section{Exception Status :}

\section{CLOSED}

Exception Closed By : Dunlap kJ ceist gfeet.

\section{APPROVAL OF RESOLUTION}

Contractor Representative: (Only as needed)

Date:

WMH Representative:

Date:

Additional Approval:

Date:

(Only as needed)

Date: 
ATP_YN : Y

Exception :

Test : 13027A-87.09

Step : 69

Equipment Tag \#: DO-203, LT-201D

Revision: 0

Date:

\begin{tabular}{ll} 
Specification Section : & $13027 \mathrm{~A}$ \\
\hline Test Witness/Author: & LeIst
\end{tabular}

Test Operator:

\begin{tabular}{ll} 
Responsible Company: & WMH \\
\hline Responsible Subcontractor: & \\
\hline Responsible Individual: & LeIst
\end{tabular}

Exception Description :

The lift table stopped before the lid could seal against the port. The lift table had to be raised manually to gain a seal.

\section{Exception Disposition :}

Adjusted switch, but Lid in Pos. switch to be replaced. Vacuum begins at "Centering Position". Lift Table to raise until "Lid in Position" sensed.

\section{Exception Status :}

6-11-97 - Lift table stop command modified so that when seeking "Lid in Position", elther the lid in position switch or vacuum present will shut off lift table. Need to add plunger switch if possible. Lift table to be reprogrammed so that lift table height is limited when seeking lid in position. 7-2-97 MPL - See exception 112. Fix will not work and must be removed.

Exception Closed By: Leist Kfhend $11 / 16 / 97$ Date : 9/2/97

\section{APPROVALOF RESOLUTION}

Contractor Representative:

(Only as needed)

Date:

WMH Representative:

Date:

Additional Approval:

(Only as needed)

Date:

FDNW Representative:

Date: 
ATP_YN : Y

$$
\text { A- } 3
$$

Test : 13027A-87.12

Step : $35-37$

Equipment Tag \#: DO-203

\section{Exception :}

Revision: 0

Date:

Specification Section : 13027A

Test Witness/Author:

LeIst

Test Operator:

\begin{tabular}{ll} 
Responsible Company: & WMH \\
\hline Responsible Subcontractor : & \\
\hline Responsible Individual: & LeIst
\end{tabular}

Exception Description :

On testing DO-202, DO-203 was inadvertantly cycled. A DO-203 "Drum Centering Device in Abnormal Position" was yielded. On inspection, the east device was found it appears the all thread used is binding in the hole.

\section{Exception Disposition :}

Add note to OP procedure. Note added.

\section{Exception Status :}

\section{Exception Closed By : Leist \\ APPROVAL OF RESOLUTION}

Contractor Representative: (Only as needed)

Date:

WMH Representative:

Date:

Additional Approval: (Only as needed)

Date: 
ATP_YN : Y

Exception :

Test : 13027A-87.09

Step :

Equipment Tag \#: DO-203

Revision : 0

Date:

Specification Section: $13027 \mathrm{~A}$

Test Witness/Author :

Leist

Test Operator:

\begin{tabular}{l} 
Responsible Company: $\quad$ WMH \\
\hline Responsible Subcontractor : \\
\hline Responsible Individual: $\quad$ Leist
\end{tabular}

Exception Description :

HVAC seal moves the empty drum to out of alignment. Pressure in seal reduced to 5 psig and alignment could be maintained.

\section{Exception Disposition :}

Fixed.

\section{Exception Status :}

CLOSED

Exception Closed By : Leist

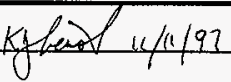

Date : $5 / 7 / 97$

\section{APPROVAL OF RESOLUTION}

Contractor Representative:

(Only as needed)

Date:

WMH Representative:

Date:

Additional Approval:

(Only as needed)

Date:

FDNW Representative:

Date: 
ATP_YN : Y

\section{Exception :}

Test : 13027A-87.09

Step : 74

Equipment Tag \#: DO-203, LT-201D

Revision : 0

Date:

Specification Section : 13027A

Test Witness/Author :

LeIst

Test Operator:

Responsible Company: $\quad$ WMH
\begin{tabular}{ll} 
Responsible Subcontractor: & \\
\hline Responsible Individual: & Lelst
\end{tabular}

Exception Description :

Lift Table did not raise after seal inflates and lid in position sensor activated, centering guides aiso extended cause not known.

\section{Exception Disposition :}

? Problem sourced w/Lid in Position Sensor. Notify DOE of condition and replace Lid in Position sensor.

\section{Exception Status :}

9-2-97-KJ Leist to fine tune sensors for all Entry/Exit Ports.

Exception Closed By :

Date:

\section{APPROVAL OF RESOLUTION}

Contractor Representative:

Date:

(Only as needed)

Date:

Additional Approval:

Date:

(Only as needed)

Date: 
Test : 13027A-87.10

Step : 10,12

Equipment Tag \#: EM-201, CR-201

Date:

Specification Section : $13027 \mathrm{~A}$

Test Witness/Author :

Leist

Test Operator:

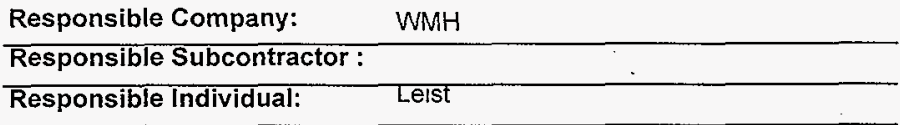

\section{Exception Description :}

Hoist cannot get past manipulator without sgnificant manpower. If the jar mill is not in the design position, the hoist and cake stand cannot be taken to the stabilization station.

\section{Exception Disposition :}

Modify procedures to provice caution information. Reinforce $D O-202$ sensors, tubing on lock bolit to withstand collision. Consider removal of jar mill. Notify DOE of condition and request funds for change.

$$
\text { Seusors (hock Bolt) relocated }
$$

\section{Exception Status :}

Exception Closed By :

Date :

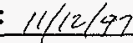

\section{APPROVAL OF RESOLUTION}

Contractor Representative: (Only as needed)

WMH Representative:

Date:

Date:

Additional Approval:

Date:

(Only as needed)

Date: 


$$
4-7
$$

ATP_YN : Y

Test : $13027 \mathrm{~A}-87.02$

Step : 15,16

Equipment Tag \#: DO-202

Exception :

Revision : 0

Date:

Specification Section: $\quad 13027 \mathrm{~A}$

Test Witness/Author :

Leist

Test Operator:

\begin{tabular}{|c|c|}
\hline \multirow{2}{*}{$\begin{array}{l}\text { Responsible Company: } \\
\text { Responsible Subcontractor: }\end{array}$} & WMH \\
\hline & \\
\hline
\end{tabular}

Exception Description :

Lid detach cylinder damages lid. This is in the location of the future HEPA filter and may damage filter.

\section{Exception Disposition :}

Reduced pressure of cylinder

$k g 11 / 197$

\section{Exception Status :}

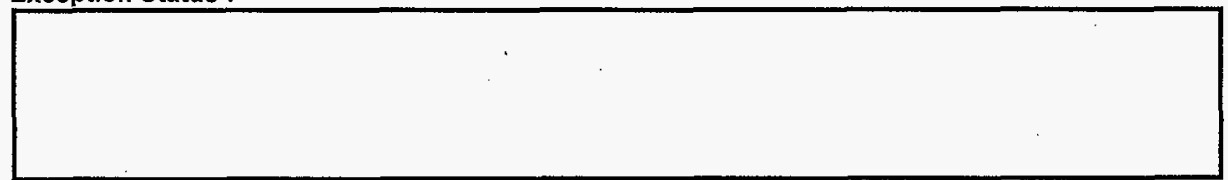

Exception Closed By : Leist

Date : $9 / 2 / 97$

\section{APPROVAL OF RESOLUTION}

Contractor Representative:

Date:

(Only as needed)

WMH Representative:

Date:

Additional Approval:

Date:

(Only as needed)

FDNW Representative:

Date: 
ATP_YN : Y

Exception :

Test : 13027 A-87.07, A.85

Step : 45,50

Equipment Tag \#: DO-201,LT201F

Revision: 0

Date:

Specification Section: $13027 \mathrm{~A}$

Test Witness/Author:

LeIst

Test Operator:

Responsible Company: WMH

Responsible Subcontractor:

Responsible Individual: LeISt

Exception Description :

THIS TEST EXCEPTION APPLIES TO ALL BAGLESS TRANSFER PORTS; DO-07-105, -201, -305, -308, -407:LaST expected output requires that when the door is open, the lift table weight does not fall below the setpoint. it does, as expected, as the downpressure of the door is relieved.

\section{Exception Disposition :}

This is normal.

\section{Exception Status :}

CLOSED

Exception Closed By : Leist

\section{APPROVAL OF RESOLUTION}

Contractor Representative:

(Only as needed)

Date:

WMH Representative:

Date:

Additional Approval:

(Oniy as needed)

Date:

FDNW Representative:

Date: 
WRAP ACCEPTANCE TEST PROCEDURE EXCEPTION LOG

$$
A-9
$$

ATP_YN : Y

Exception :

Test : $13027 \mathrm{~A}-87.07$

Step : 33

Equipment Tag \#: DO-201, LT-201F

Revision : 0

Date:

Specification Section: $13027 \mathrm{~A}$

Test Witness/Author :

LeIst

Test Operator:

Responsible Company: WMH

Responsible Subcontractor :

Responsible Individual: Schaeffer

Exception Description :

In maintenance mode, the drum will run of the end of the conveyor.

Exception Disposition :

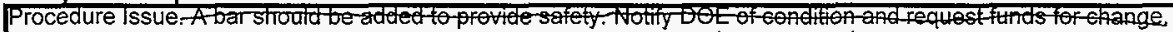

$$
\text { KJe } 11 / 11 / 97 \text { Note added to procediure. }
$$

\section{Exception Status :}

and add note to operating procedure.

$$
x / 2=1 / 47
$$

Exception Closed By :

\section{APPROVAL OF RESOLUTION}

Contractor Representative:

Date:

(Only as needed)

WMH Representative:

Date:

Additional Approval:

(Only as needed)

Date:

FDNW Representative:

Date: 
ATP_YN : $Y$

Exception :

Test : 13027A-87.06,87.23

Step : 11

Equipment Tag \#: DO-203

Revision : 0

Date:

Specification Section: $13027 \mathrm{~A}$

Test Witness/Author:

LeIst

Test Operator:

\begin{tabular}{ll} 
Responsible Company: & WMH \\
\hline Responsible Subcontractor: & \\
\hline Responsible Individual: & LeIst
\end{tabular}

\section{Exception Description :}

Lid in position does not trigger. It appears that the lid detach cylinder is pushing too hard and has deformed the lid. The lid springs back on vacuum but this must be manually provided. In trying to get a lid in position message, The lift table is forcing the door open 1/4" against the lock bolts.

\section{Exception Disposition :}

Problem sourced in Lid in Position sensor, and "Lid Detach" cylinder. Notify DOE of condition and requeșt funds for change.

\section{Exception Status :}

7-2-97-MPL - Capacitive sensors replace inductive Lid in Position sensors. Tested satistactory. 9-2-97 - Duplicate of \#7. Closed.

Exception Closed By: Leist

Date : $9 / 2 / 97$

\section{APPROVAL OF RESOLUTION}

Contractor Representative: (Only as needed)

Date:

WMH Representative:

Date:

Additional Approval:

(Only as needed)

Date:

Date: 
ATP_YN : Y

Exception :

Test : $13027 \mathrm{~A}-87.05$

Step :

Equipment Tag \#: DO-202

Revision : 0

Date:

Specification Section : $13027 \mathrm{~A}$

Test Witness/Author:

LeIst

Test Operator:

\begin{tabular}{l} 
Responsible Company: $\quad$ WMH \\
\hline Responsible Subcontractor: \\
\hline Responsible Individual: $\quad$ Lane
\end{tabular}

Exception Description :

Entryltexit Door arms raise off plate when venting occurs and Ifft table lifts door into position. This prevents the Door in Position switch from actuating.

\section{Exception Disposition:}

sll to add code to have door cylinder to hold arms down whenever the three door lifting cylinders are vented.

\section{Exception Status :}

CLOSED

\section{Exception Closed By : Leist \\ APPROVAL OF RESOLUTION}

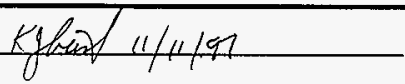

Date : $5 / 7 / 97$

Contractor Representative:

(Only as needed)

Date:

WMH Representative:

Date:

Additional Approval:

(Onily as needed)

Date:

FDNW Representative:

Date: 
WRAP ACCEPTANCE TEST PROCEDURE EXCEPTION LOG

$$
A-12
$$

ATP_YN : $Y$

Exception :

Test : 13027A-87.02

Step : 11,12

Equipment Tag \#: DO-202,DO-203,DO-101,300,

Revision: 0

Date: 301

Specification Section: $13027 \mathrm{~A}$

Test Witness/Author :

Leist

Test Operator:

Responsible Company:

WMH

Responsible Subcontractor :

Responsible Individual: Lane

Exception Description :

Screen message says "Open Port" and "Close Port". This is confusing WRT. "RAISE DOOR" and "LOWER DOOR". This applied to all E/E ports.

\section{Exception Disposition :}

Change to "Rotate Open" and "Rotate Closed".

11/11/47. torom dif thanged

\section{Exception Status :}

CLOSED? All ports. 6-11-97 (MPL) Actually changed to "ROTATE PORT OPEN" and "ROTATE PORT CLOSED" for consistency with other commands. Applied to all other Entry/Exit Ports.

Exception Closed By: LeIst

Date : $5 / 7 / 97$

\section{APPROVAL OF RESOLUTION}

Contractor Representative:

(Only as needed)

Date:

WMH Representative:

Date:

Additional Approval:

Date:

(Only as needed)

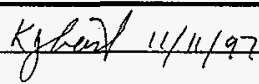

FDNW Representative:

Date: 


$$
A-13
$$

\section{Exception :}

Revision : 0

Test : 13027A-87.01

Step : 23

Equipment Tag \#: DO-201

Date:

Specification Section : $13027 \mathrm{~A}$

Test Witness/Author:

LeIst

Test Operator:

\begin{tabular}{ll} 
Responsible Company: & WMH \\
\hline Responsible Subcontractor: & \\
\hline Responsible Individual: & Lelst
\end{tabular}

Exception Description :

too not avallable for Babcock drum opening.

\section{Exception Disposition :}

Tool found w/FDNW.

\section{Exception Status:}

CLOSED

Exception Closed By : Leist

\section{APPROVAL: OF RESOLUTION}

Contractor Representative:

(Only as needed)

Date:

WMH Representative:

Date:

Additional Approval:

(Only as needed)

Date:

FDNW Representative:

Date: 
ATP_YN : Y

Exception :

Test : 13027A-Setup

Step : 23

Equipment Tag \#: 107-EM-07-201

Revision : 0

Date:

Specification Section : $13027 \mathrm{~A}$

Test Witness/Author :

Lelst

Test Operator:

Responsible Company: WMH

Responsible Subcontractor :

Responsible Individual: Lelst

Exception Description :

Manipulator cannot be raised to upper limit until hydraulics are repaired.

\section{Exception Disposition :}

\section{Exception Status :}

9-2-97 Fixed by schilling. closed.

Exception Closed By : Leist $\operatorname{sg} \operatorname{len} / 11 / 197$

Date : $9 / 2 / 97$

\section{APPROVAL OF RESOLUTION}

Contractor Representative:

(Only as needed)

Date:

WMH Representative:

Date:

Additional Approval:

Date:

(Only as needed)

FDNW Representative:

Date: 
ATP_YN : Y

$$
A \cdot 15
$$

Test : $13027 \mathrm{~A}-87.03$

Step : 4

Equipment Tag \#: DO-203

\section{Exception :}

Revision : 0

Date:

Specification Section : $13027 \mathrm{~A}$

Test Witness/Author :

Test Operator:

\begin{tabular}{ll} 
Responsible Company: & WMH \\
\hline Responsible Subcontractor: & \\
\hline Responsible Individual: & Lelst \\
\hline
\end{tabular}

Exception Description :

Door locked cylinder frozen in position until piping cracked to release. Worked ok thereafter until air turned of again.

\section{Exception Disposition :}

Cause not known.

\section{Exception Status :}

9-2-97 Worklist item generated to install different mounting bolts to allow lock cylinder to float. "//4 $/ 47$ Air cylinches Bated per deriga.

Exception Closed By :

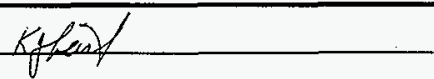

Date : $11 / 11 / 92$

\section{APPROVAL OF RESOLUTION}

Contractor Representative:

(Only as needed)

Date:

WMH Representative:

Date:

Additional Approval:

Date:

(Only as needed)

Date: 
Exception :

ATP_YN : Y

Revision: 0

Test : $13027 \mathrm{~A}-87.17$

Step :

Equipment Tag \#: LT-201D, E, F

Date:

Specification Section: $13027 \mathrm{~A}$

Test Witness/Author:

Leist

Test Operator:

\begin{tabular}{l} 
Responsible Company: $\quad$ WMH \\
\hline Responsible Subcontractor : \\
\hline Responsible Individual: $\quad$ Leist
\end{tabular}

Exception Description :

Lift tables not tested per data sheets (step 17)

\section{Exception Disposition :}

Operability of liff tables will be deomonstrated through testing of $\mathrm{G} / \mathrm{B}$.

Testing completed successfully with exceptions as documented in MTEL.

\section{Exception Status :}

CLOSED

Exception Closed By : Leist

\section{APPROVAL OF RESOLUTION}

Contractor Representative:

Date:

(Only as needed)

Date:

WMH Representative:

Date:

Additional Approval:

(Only as needed)

Date:

FDNW Representative: 
ATP_YN : Y

$$
A \sim 1\}
$$

Exception :

Test : $13027 \mathrm{~A}-87.13$

Step : 38

Equipment Tag \#: .DO-203

Revision : 0

Date:

Specification Section : $13027 \mathrm{~A}$

Test Witness/Author:

\section{LeIst}

Test Operator:

\begin{tabular}{|c|c|}
\hline Responsible Company: & WMH \\
\hline Responsible Subcontractor: & \\
\hline Responsible Individual: & Lane \\
\hline
\end{tabular}

Exception Description :

Abnormal position switch (DCD) alarm found. Not mentioned in test. This should be expected.

\section{Exception Disposition :}

Add to test. Documentation provided by this reference.

\section{Exception Status :}

CLOSED

Exception Closed By: Lane Mnchal Pefar

Date : 7/2/97 9.17.6,

\section{APPROVAL OF RESOLUTION}

Contractor Representative:

(Onily as needed)

Date:

WMH Representative:

Date:

Additional Approval:

(Only as needed)

Date:

FDNW Representative:

Date: 
ATP_YN : Y

$$
A \neg 18
$$

Exception :

Test : 13027A-87.13

Step :

Equipment Tag \#: DO-07-203

Revision : 0

Date:

Specification Section: 13462

Test Witness/Author :

LeIst

Test Operator:

Responsible Company: WMH

Responsible Subcontractor : SII

Responsible Individual: Leist

Exception Description :

LocalE-stop doesn't stop port from closing.

\section{Exception Disposition :}

FIX and retest. Fixed Automode only. E-Stop should not work in Maint. Mode. 6-17-97 (MPL) RWM glovebox local emergency stops should and do work in maintenance mode. Ken Leist to concur and sign off.

\section{Exception Status :}

CLOSED

Exception Closed By : Leist Khant $1 / 12 / 97$

Date : $5 / 7 / 97$

\section{APPROVAL OF RESOLUTION}

Contractor Representative:

Date:

(Only as needed)

WMH Representative:

Date:

Additional Approval:

Date:

(Only as needed)

FDNW Representative:

Date: 


\section{WRAP ACCEPTANCE TEST PROCEDURE} EXCEPTION LOG

$$
A \cdot 19
$$

ATP_YN : $Y$

\section{Exception :}

Test : 13027A-87.08

Step : $62 a-62 d$

Equipment Tag \#: LT-09-201E

Revision : 0

Date:

Specification Section : $13027 \mathrm{~A}$

Test Witness/Author :

\section{Leist}

Test Operator:

Responsible Company: WMH

Responsible Subcontractor:

Responsible Individual: Lane

Exception Description :

Lift Table tripped out during testing. Port would not continue closing.

\section{Exception Disposition :}

Force issue - Error 22. Caused by Lid in Position sensor. Logic should have lift table go to slow at set position. Vacuum start, then lift stop when vacuum, Lid in Position switches closed.

\section{Exception Status :}

6-17-97 This appears to be an operator/procedural error. Retested satisfactory. Ken Leist to concur.

\section{Exception Closed By : Leist}

Date:

Contractor Representative:

(Only as needed)

WMH Representative:

Date:

Additional Approval:

Date:

(Only as needed)

\section{APPROVAL OF RESOLUTION}


ATP_YN : Y

Exception :

Test : 13027A-87.08

Step : $62 \mathrm{a}-62 \mathrm{~d}$

Equipment Tag \#: DO-202

Revision : 0

Date:

Specification Section : $13027 \mathrm{~A}$

Test Witness/Author:

Lelst

Test Operator:

Responsible Company: WMH

Responsible Subcontractor:

Responsible Individual: Lane

Exception Description :

When the Port door rotates closed, the main cyclinder stops retracting. Once the port door rotated closed sensor is sensed. This does not allow the cylinder to develop down pressure. On opening, in the next cycle, the arms raise off the floor before being forced down again.

\section{Exception Disposition :}

Have the matn cylinders continue retracting unti the port door lock cyclinders are extended. Fixed.

\section{Exception Status :}

\section{CLOSED}

Exception Closed By: Leist Kflas $11 / 11 / 97$

Date : $5 / 7 / 97$

\section{APPROVAL OF RESOLUTION}

Contractor Representative:

Date:

(Only as needed)

WMH Representative:

Date:

Additional Approval:

Date:

(Only as needed)

FDNW Representative:

Date: 
ATP_YN : Y

\section{Exception :}

Test : 13027A-87-08

Step : $62 \mathrm{a}-62 \mathrm{~d}$

Equipment Tag \#: DO-02

Revision : 0

Date:

Specification Section : $13027 \mathrm{~A}$

Test Witness/Author:

LeIst

Test Operator:

Responsible Company: WMH

Responsible Subcontractor:

Responsible Individual: Lane

Exception Description :

When the Entrylexit door lowering cylinders vent to lower the door to the "Drum in Position" position, a distinct "Foop" sound is heard. The source was found not to be the "Lid Detach Cylinder extending. However the source of the sound was not found.

\section{Exception Disposition :}

Source not found.

5/6/97 - Source found to be sound of vacuum release. Vacuum must be held until door reaches Drum in Position height. Lid Detach should extend at same time.

\section{Exception Status :}

7-2-97-MPL - Ladder logic, port operation matches above description. Ken Leist toncur and close exception.

Exception Closed By: Leist K/hend/1/14/97 Date : 9/2/97

\section{APPROVAL OF RESOLUTION}

Contractor Representative:

Date:

(Only as needed)

Date:

WMH Representative:

Date:

Additional Approval:

(Only as needed)

FDNW Representative:

Date: 
ATP_YN : Y

Exception :

Test : 13027A-87.08

Step : 62a-62d Equipment Tag \#: DO-202

Revision : 0

Date:

Specification Section : $13027 \mathrm{~A}$

Test Witness/Author :

LeIst

Test Operator:

Responsible Company: $\quad$ WMH

Responsible Subcontractor:

Responsible Individual: Lane

Exception Description :

When the "Close Port" is pressed after port opeing is pressed, the port temporarily closes, then it also lets go of the lid. This applies to all ports and at all sequences.

\section{Exception Disposition :}

\section{Fixed?}

When port is opened, the Close command is locked out.

\section{Exception Status :}

CLOSED

Exception Closed By: Lane Thicrael Pfax Date: 7/2/97 9-179.

\section{APPROVAL OF RESOLUTION}

Contractor Representative:

(Only as needed)

Date:

WMH Representative:

Date:

Additional Approval:

(Only as needed)

Date:

FDNW Representative:

Date: 
ATP_YN : Y

Exception :

Test : $13027 \mathrm{~A}-87.08$

Step : $62 \mathrm{a}-62 \mathrm{~d}$

Equipment Tag \#: DO-202

Revision : 0

Date:

Specification Section: $13027 \mathrm{~A}$

Test Witness/Author :

Leist

Test Operator:

\begin{tabular}{l} 
Responsible Company: $\quad$ WMH \\
\hline Responsible Subcontractor: \\
\hline Responsible Individual: Lane
\end{tabular}

Exception Description :

Although alarm is noted, and clears when the "Drum in Centering Position" is reached, the "Sequence Failed" message continues to flash. D0-202, DO-201, transfer stand.

\section{Exception Disposition :}

Standardize OIU alarm triggers and add "=l" trigger statements to logic. Fixed.

\section{Exception Status :}

CLOSED

\section{Exception Closed By : Leist \\ APPROVAL OF RESOLUTION}

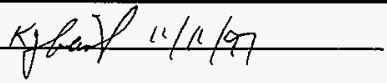

Date : 5/7/97

Contractor Representative:

(Only as needed)

Date:

WMH Representative:

Date:

Additional Approval:

(Only as needed)

Date:

FDNW Representative:

Date: 
ATP_YN : Y

Exception :

Test : 13027A-87.22

Step : 24

Equipment Tag \#: DO-202

Revision: 0

Date:

Specification Section: $13027 \mathrm{~A}$

Test Witness/Author :

Leist

Test Operator:

\begin{tabular}{|c|c|}
\hline Responsible Company: & WMH \\
\hline Responsible Subcontractor: & \\
\hline
\end{tabular}

Exception Description :

On port closing, the E-Stop was activated. On reset, the door stopped closing at the point where the port was in the rotated closed position. The HVAC seal did not re-inflate, the drum center grabs did not extend.

\section{Exception Disposition :}

Change logic to have DCD's remain in position during E-Stop. Verified.

\section{Exception Status :}

CLOSED

\section{Exception Closed By : Leist \\ APPROVAL OF RESOLUTION}

Contractor Representative:

(Only as needed)

Date:

WMH Representative:

Date:

Additional Approval:

(Only as needed)

Date:

FDNW Representative:

Date: 
ATP_YN : Y

\section{Exception :}

Test : 13027A-87.22

Step : 16,21

Equipment Tag \#: DO-202

Revision : 0

Date:

Specification Section : $13027 \mathrm{~A}$

Test Witness/Author:

\section{LeISt}

Test Operator:

\begin{tabular}{|c|c|}
\hline Responsible Company: & WMH \\
\hline Responsible Subcontractor: & \\
\hline Responsible Individual: & Lane \\
\hline
\end{tabular}

Exception Description :

When E-Stop is activated, the drum grabs retract. The HVAC seal depressurized too.

Exception Disposition :

Ovenview, the orum Grabs should retract and therefore should stay as is. The HVAC boot must remain inflated. Change the logic to close or keep the DCD cylinders extended during E-Stop.

\section{Exception Status :}

CL

\section{Exception Closed By: Leist Keftefl/10/47}

\section{APPROVAL OF RESOLUTION}

Contractor Representative:

(Only as needed)

Date:

WMH Representative:

Date:

Additional Approval:

(Only as needed)

Date:

Date: 
ATP_YN : Y

Test : 13027A-87.21

Step : $16-19,24-29$ Equipment Tag \#: DO-201

Exception :

Revision: 0

Date:

Specification Section : $\quad 13027 \mathrm{~A}$

Test Witness/Author :

LeIst

Test Operator:

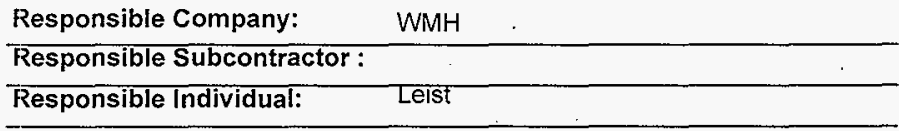

\section{Exception Description :}

Actual operation of port not reflected by test procedure. Port controller must manually be placed in manual mode. This cannot happen until after E-Stop is reset. OlU cannot know position of DO-201 after E-Stop activation. After EStop, port must always be placed into the closed position before Auto mode can be chosen.

\section{Exception Disposition :}

pest performed successfully using edited criteria. See test report.

\section{Exception Status :}

\section{CLOSED}

Exception Closed By : Leist

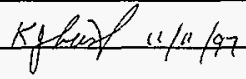

Date : $5 / 7 / 97$

\section{APPROVAL OF RESOLUTION}

Contractor Representative:

Date:

(Only as needed)

WMH Representative:

Date:

Additional Approval:

Date:

(Only as needed)

Date: 
ATP_YN : Y

Exception :

Test : 13027A-87.21

Step :

Equipment Tag \#: DO-201

Revision : 0

Date:

Specification Section: $13027 \mathrm{~A}$

Test Witness/Author:

Leist

Test Operator:

\begin{tabular}{l} 
Responsible Company: $\quad$ WMH \\
\hline Responsible Subcontractor: \\
\hline Responsible Individual:
\end{tabular}

Exception Description :

OIU does not display that E-Stop has been activated.

\section{Exception Disposition :}

Add global message to Oां screen to display E-Stop activation. Verified.

\section{Exception Status :}

CLOSED 7-2-97-MPL E-stop alarm added. E-stop indicator added to Maintenance Main Menu.

\section{Exception Closed By : Leist}

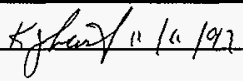

Date : $5 / 7 / 97$

\section{APPROVAL OF RESOLUTION}

Contractor Representative:

Date:

(Only as needed)

WMH Representative:

Date:

Additional Approval:

Date:

(Only as needed)

FDNW Representative:

Date: 
WRAP ACCEPTANCE TEST PROCEDURE EXCEPTION LOG

$$
\text { A- } 28
$$

ATP_YN : $Y$

Exception :

Test : 13027A-87.21

Step : 15,24

Equipment Tag \#: DO-201

Revision : 0

Date:

Specification Section: $13027 \mathrm{~A}$

Test Witness/Author :

LeIst

Test Operator:

$\begin{aligned} & \text { Responsible Company: } \\
& \text { Responsible Subcontractor: }\end{aligned}$
\begin{tabular}{l} 
Responsible Individual: \\
\hline
\end{tabular}

Exception Description :

Door slowly lowers during E-Stop test. Suspect air leak.

Exception Disposition :

Fix air leak.

\section{Exception Status :}

9-2-97 - KJ Leist to verify and retest.

Exception Closed By :

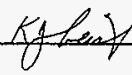

Date: $11 / 11 / 97$

\section{APPROVAL OF RESOLUTION}

Contractor Representative:

(Only as needed)

Date:

WMH Representative:

Date:

Additional Approval:

(Only as needed)

Date:

FDNW Representative:

Date: 
ATP_YN : Y

Exception :

Test : 13027A-87.21

Step : ALL Equipment Tag \#: DO-201

Revision :

Date:

Specification Section : $13027 \mathrm{~A}$

Test Witness/Author:

Lane

Test Operator:

Responsible Company: WMH

Responsible Subcontractor:

Responsible Individual: Lane

Exception Description :

Local Emergency stop not tested for maintenance mode operation because this is not part of test.

Exception Disposition :

rest maintenance mode local emergency stop operation prior to glovebox operation.

\section{Exception Status :}

9-2-97 MP Lane to review test notes, test procedure, and retest as necessary.

Exception Closed By :

Date :

\section{APPROVAL OF RESOLUTION}

Contractor Representative:

Date:

(Only as needed)

WMH Representative:

Date:

Additional Approval:

Date:

(Only as needed)

FDNW Representative:

Date: 
ATP_YN : Y

$$
A-30
$$

Exception :

Test : 13027A-87.21

Step : ALL

Equipment Tag \#: DO-201

Revision :

Date:

Specification Section: $13027 \mathrm{~A}$

Test Witness/Author: Lane

Test Operator:

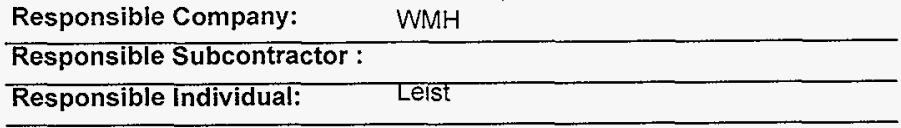

Exception Description:

NOOTIFY DOE AND REQUEST FUNDSFORFIX:

THIS EXCEPTION APPLIES TO ALL ENTRY/EXIT PORTS: Entry/Exit port Locking cylinder sensors are positioned so that the sensors indicate full retraction even though the cylinders may be only partially retracted. It is likely that

the locking cylinders, at some time in the future, will not fully retract causing the port door to impact the locking

cylinders. This may cause equipment damage.

\section{Exception Disposition :}

Options:

1. Replace existing locking cylinder with FESTO cylinder similar to lid detach cylinder. Use in-line cylinder sensors similar to $07-Z S-900 \mathrm{~B}$ to sense full cylinder extension and retraction.

2. Use existing cylinders and be prepared for damage incident.

\section{Exception Status :}

9-2-97 KJ Leist and MP Lane to write CR to change out to cylinder with 2 sensors per cylinder. Need to determine change required and order parts. 1/11/97. New lockg swriches added to indicate lockod and en locked seositions.

Exception Closed By :

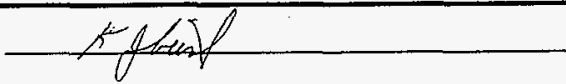

Date :

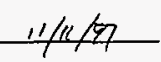

\section{APPROVAL OF RESOLUTION}

Contractor Representative:

Date:

(Only as needed)

WMH Representative:

Date:

Additional Approval:

Date:

(Only as needed)

Date: 
WRAP ACCEPTANCE TEST PROCEDURE EXCEPTION LOG

$$
A-3 L
$$

ATP_YN : Y

\section{Exception :}

Test : $13027 \mathrm{~A}-87.26$

Step : 17

Equipment Tag \#: DO-203

Revision :

Date:

Specification Section: $13027 \mathrm{~A}$

Test Witness/Author:

Leist

Test Operator:

Responsible Company: WMH

Responsible Subcontractor:

Responsible Individual: Lelst

Exception Description :

Vacuum generator does not release when "Vacuum OFF" is pressed.

Exception Disposition :

Replace valve.

Exception Status :

CLOSED

Exception Closed By : Leist

rghark $u / k / 9$

Date : $5 / 7 / 97$

\section{APPROVAL OF RESOLUTION}

Contractor Representative:

Date:

(Only as needed)

WMH Representative:

Date:

Additional Approval:

Date:

(Only as needed)

FDNW Representative:

Date: 


\section{Exception :}

ATP_YN : Y

DESIGN

Test :

Step :

Equipment Tag \#:

Revision :

Date:

Specification Section :

Test Witness/Author :

Test Operator:

\begin{tabular}{ll} 
Responsible Company: & WMH \\
\hline Responsible Subcontractor : & Leist \\
\hline Responsible Individual: $\quad$ Len
\end{tabular}

Exception Description :

This exception applies to all Entry/Exit Ports, Bagless Transfer ports. E-Stop doesn't stop port from lowering or raising.

\section{Exception Disposition :}

Exception Status :

9-2-97 KJ Leist to initate change request. Need to order parts.

E/E pouts and one trip port Raise/Lowe- Control values and software revised. BTP's T valves - is hand, but software has nof been reuised.

Exception Closed By :

Date :

\section{APPROVAL OF RESOLUTION}

Contractor Representative:

Date:

(Only as needed)

WMH Representative:

Date:

Additional Approval:

Date:

(Only as needed)

Date: 
ATP_YN : Y

HW

Test : $13027 \mathrm{~B}-88.20$

Step : 15

Equipment Tag \#: LT-09-201A
Exception :

Revision :

Date:

Specification Section : 13027B

Test Witness/Author:

LeIst

Test Operator:

Responsible Company: WMH

Responsible Subcontractor:

Responsible Individual: Schaeffer

\section{Exception Description :}

The Lift Table lowered by itself during E-Stop testing. No E-Stop activities on the 401B had been done this time. Cause not believed to be software. Previous similar incidents have been recollected for this Lift Table.

\section{Exception Disposition :}

6-77-97 - MPL - Mr. Jordal indicates that he will start a work package to have wiring wrung out for lift table LT-09$201 \mathrm{~A}$

\section{Exception Status :}

9-2-97 Electricians find no wiring problems. MPLane to review code for extraneous block move. Electricians to provide additional support as needed.

9-18-97 Can operate in maint. not auto - MPL working.

9-25-97 Revise POPs.

Exception Closed By :

Date :

\section{APPROVAL OF RESOLUTION}

Contractor Representative:

(Only as needed)

WMH Representative:

Date:

Date:

Additional Approval:

Date:

(Only as needed)

Date: 
WRAP ACCEPTANCE TEST PROCEDURE

EXCEPTION LOG

$A-34$

ATP_YN : Y

DESIGN

\section{Exception :}

Test : 13027B-88.11

Step : 3

Equipment Tag \#: DO-07-107,...

Revision :

Date:

Specification Section : $13027 \mathrm{~B}$

Test Witness/Author :

LeIst

Test Operator:

Responsible Company: WMH

Responsible Subcontractor:

Responsible Individual: Lelst

Exception Description :

Cannot test cell when Sample Transfer Port container is in the locked and unlocked positions.

Exception Disposition :

Add permanent marks to port assembly with verbage locked, unlocked which line up with container pins.

\section{Exception Status :}

$$
\text { Fu. tulled. }
$$

Exception Closed By :

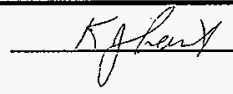

\section{APPROVAL OF RESOLUTION}

Contractor Representative:

Date:

(Only as needed)

WMH Representative:

Date:

Additional Approval:

Date:

(Only as needed)

Date: 
ATP_YN : Y

DESIGN

Test : 13027B-88.10

Step :

\section{Exception :}

Revision :

Date:

Specification Section : $13027 \mathrm{~B}$

Test Witness/Author :

Leist

Test Operator:

\section{Responsible Company: WMH}

\section{Responsible Subcontractor:}

\section{Responsible Individual: Schaeffer}

\section{Exception Description :}

Jarmill wil be damaged by manipulators. This is cue to the size of the jarmill, its locafion (due to its size), and the fact that lock valves are not present in the manipulator. The manipulator sags in the jarmill. This issue a $/ 50$

$$
\text { a Fects } 6 B 201 \mathrm{kje} / 1 / 11 / 97
$$

\section{Exception Disposition :}

9-2-97 - KJ Leist to initiate CR to add locking valves for manipulator arms OR to take manipulators out of box (e.g., use as spares...).

\section{Exception Status :}

9-3-97 Address by operating procedure. Tar mils removed. $1 / / 1 / 97$

Exception Closed By :

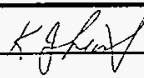

Date: $11 / 11 / 97$

\section{APPROVAL OF RESOLUTION}

Contractor Representative:

Date:

(Only as needed)

WMH Representative:

Date:

Additional Approval:

Date:

(Only as needed)

Date: 
WRAP ACCEPTANCE TEST PROCEDURE EXCEPTION LOG

ATP_YN : Y

\section{Exception :}

Test : 13027B-88

Step :

Equipment Tag \#:

$E M+\infty$

Li: $i$

Revision :

Date:

Specification Section : $13027 \mathrm{~B}$

Test Witness/Author:

Leist

Test Operator:

Responsible Company: WMH

Responsible Subcontractor :

Responsible Individual: Leist

Exception Description :

Manipulator Tool Air Supply is sourced upstream of the glovebox air valves, i.e. the olU cannot turn off the air.

\section{Exception Disposition :}

\section{Exception Status :}

9-3-97 101 glovebox fixed. Parts present. Ken Leist to ensure remainder of gloveboxes fixed.

9-18-97 Done. WR to check.

WP 97-0322

Exception Closed By :

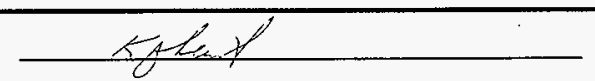

Date: $1 / 11 / 4\rangle$

\section{APPROVAL OF RESOLUTION}

Contractor Representative:

Date:

(Only as needed)

WMH Representative:

Date:

Additional Approval:

Date:

(Only as needed)

Date: 
WRAP ACCEPTANCE TEST PROCEDURE EXCEPTION LOG

ATP_YN : Y

Exception :

Test : 13027A-87

Step :

Equipment Tag \#: DO-202,201,101,106,301

Revision :

Date:

Specification Section: $13027 \mathrm{~A}$

Test Witness/Author:

Lést

Test Operator:

Responsible Company: WMH

Responsible Subcontractor :

Responsible Individual: Lane

Exception Description :

At the drum centering position, the lift table raises unfl the lis in position sensor coses. Concern is that the lift table will not stop at some maximum position.

Exception Disposition :

7-2-97-MPL Review lift table programming and modify as needed to prevent equipment damage.

Exception Status :

7--2-97-MPL - Programming examined. Drums placed on lift table, ralsed to lid in position height. Raised 3/16" This is new maximum height for lid in position sequence. ports unlocked, drum raised approximately $1.11 / 8$ inch above lid in position height, but always below up overtravel. Resolver readings taken. New position measured to be used as maximum travel height for drum in position sequence. This exception is therefore closed.

Exception Closed By: Lane Thicke PQea

Date : 7/2197 9-17-97

\section{APPROVAL OF RESOLUTION}

Contractor Representative:

Date:

(Only as needed)

Date:

WMH Representative:

Additional Approval:

Date:

(Only as needed)

FDNW Representative:

Date: 
ATP_YN : Y

Exception : 3

Test : $13031 \mathrm{~A}-85$

Step : $05.4,12,13,14$ Equipment Tag \#: CR-07-101A

Revision :

Date:

Specification Section : 13031

Test Witness/Author :

Warmennoven

Test Operator:

\begin{tabular}{|c|c|}
\hline Responsible Company: & WMH \\
\hline Responsible Subcontractor: & \\
\hline Responsible Individual: & Weidert \\
\hline
\end{tabular}

\section{Exception Description :}

\section{Exception Disposition :}

Revise sofware specification section 13462 to reflect modified hardware.

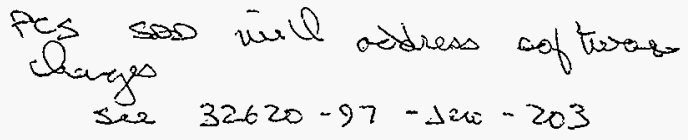

\section{Exception Status :}

9-3-97 JR Weidert to determine best course of action to update plant documentation to reflect actual as-built condition of process area software.

Exception Closed By :

Date :

\section{APPROVAL OF RESOLUTION}

Contractor Representative: (Only as needed)

WMH Representative:

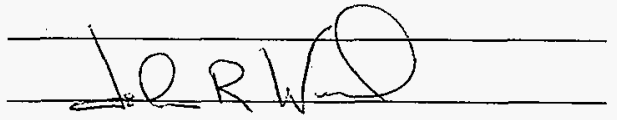

Date:

Date: $11-16-97$

Additional Approval:

(Only as needed)

Date:

Date: 
WRAP ACCEPTANCE TEST PROCEDURE

EXCEPTION LOG

$A-39$

Tracking \#: $\quad 105$

ATP_YN : Y

Exception : 27

Test : 13031A-85

Step : 07.51

Equipment Tag \#: DH-07-101

Revision :

Date:

Specification Section: 13031

Test Witness/Author:

Lane

Test Operator:

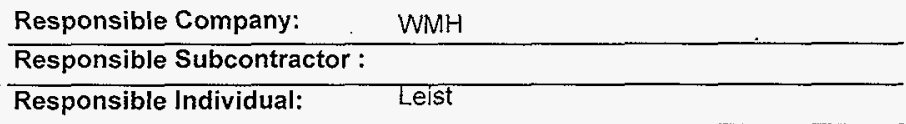

Exception Description :

6-30-97 MPL - During drum entry sequence, system established adequate vacuum sensor PS703 does not activate, sequence stops.

\section{Exception Disposition :}

6-30-97 MPL - sensor setpoint adjusted downward. Glovebox cognizant engineer to determine cause of vacuum leak, fix, and re-calibrate vacuum sensor.

\section{Exception Status :}

9-3-97 In progress. Ken Liest to order parts (suction cups), modify brackets. Geveric item WP-97-501 ltem\#25. For all E/E ports

port 202 and 203 on $W A-97-0505$

Exception Closed By :

Date :

\section{APPROVAL OF RESOLUTION}

Contractor Representative:

Date:

(Only as needed)

Date:

WMH Representative:

Date:

Additional Approval:

(Only as needed)

Date:

FDNW Representative: 
Test : $13031 \mathrm{~A}-85$

Step : ALL

Equipment Tag \#: ALL

Revision :

Date:

Specification Section : 13031

Test Witness/Author :

Lane

Test Operator:

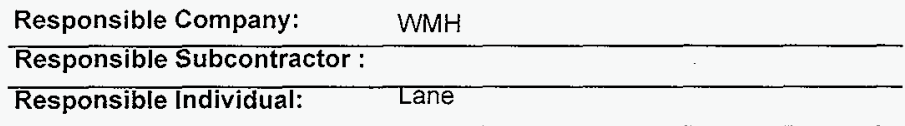

\section{Exception Description :}

6-30-97 MPL - Numerous timers in ladder logic program. Few are optimized at this time. Need sufficiently long time period so that if momentary hiccup (as appicable), alarm does not sound. Need sufficiently short time period so that if error condition occurs, alarm is generated soon after condition occurs.

\section{Exception Disposition :}

6-30-97 MPL - Mike Schneider to work with Dave Schermerhorn to create EXCEL (or equivalent) list of timers and then operate gloveboxes to determine optimum timer settings. Optimal timer settings to be recorded and applied to each glovebox.

\section{Exception Status :}

9-3-97 Excel spreadsheet created. Timer seftings to be optimized during startup/use RTAP alarm log.

Exception Closed By :

Date :

\section{APPROVAL OF RESOLUTION}

Contractor Representative:

Date:

(Only as needed)

WMH Representative:

Date:

Additional Approval:

(Only as needed)

Date:

FDNW Representative:

Date: 
ATP_YN : Y

SW

Test : 13031A.85.08

Step : 143

Equipment Tag \#: RT-07-101

Exception : 43

Revision :

Date:

Specification Section : 13031

Test Witness/Author :

Lane

Test Operator:

\begin{tabular}{l} 
Responsible Company: $\quad$ WMH \\
\begin{tabular}{l} 
Responsible Subcontractor: \\
\hline Responsible Individual:
\end{tabular} Lane \\
\hline
\end{tabular}

Exception Description :

7-22-97 MPL - THIS APPLIES TO ALL TTEMSWITHLATCHED MAINTENANCE MODE CONTROLBITS: SaW turned on in maintenance mode, switch to auto, and saw turns off. Return to majnt. mode, saw immediately restarts.

\section{Exception Disposition :}

7-22-97 MPL - This is a serious deficiency. Review all items to eliminate unexpected movement when switching from auto to maint. and back.

\section{Exception Status :}

9-3-97 MP Lane to review code.

\section{Exception Closed By :}

Date :

\section{APPROVAL OF RESOLUTION}

Contractor Representative: (Only as needed)

Date:

WMH Representative:

Date:

Additional Approval:

Date:

(Only as needed)

Date: 
ATP_YN : Y

Test : $13031 \mathrm{~A} .85 .44$

Step : 1

Equipment Tag \#: LT-09-202C

Exception : 61

Revision :

Date:

Specification Section: 13021

Test Witness/Author:

Lane

Test Operator:

\begin{tabular}{ll} 
Responsible Company: & WMH \\
\hline Responsible Stibcontractor: & \\
\hline Responsible Individual: & Jordal/Lane \\
\hline
\end{tabular}

Exception Description :

7-22-97 MPL - IHIS APPLIES TO ALL LIFT TABLES: Local emergency stops do nof $100 \%$ reliably stop lift tables from raising or lowering.

\section{Exception Disposition :}

7-22-97 MPL - sll personel to determine fix. If reliable, easily maintained fix not avallable, PCS software E-stop deactivation of lift tables will be removed as it was not part of original design and is already covered via rope switches.

\section{Exception Status :}

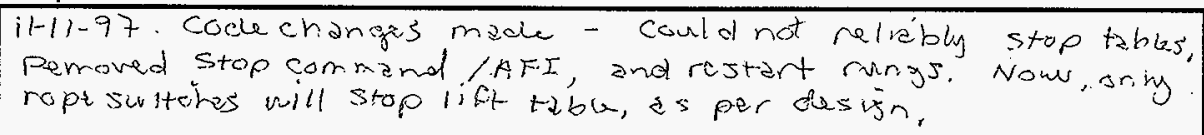

Exception Closed By :

Mickal Pdraw

Date: $12-11-97$

\section{APPROVAL OF RESOLUTION}

Contractor Representative:

(Only as needed)

Date:

WMH Representative:

Date:

Additional Approval:

(Only as needed)

Date:

Date: 


\section{WRAP ACCEPTANCE TEST PROCEDURE EXCEPTION LOG

$$
A-43
$$

ATP_YN : Y

SW

Exception : 99

Test : ALL ATP

Step : ALL

Equipment Tag \#: GB-07-101,...

Revision :

Date:

Specification Section : 13462

Test Witness/Author :

Lane

Test Operator:

\begin{tabular}{ll} 
Responsible Company: & WMH \\
\hline Responsible Subcontractor: & BDM \\
Responsible Individual: & Lane
\end{tabular}

Exception Description :

THIS AFFECTS ALL GLOVEBOX MAINTENANCE MODE OPERATIONS:

Auto to Maintenance transitions are not standardized for all glovebox operations. In certain cases, switching to

maint. mode kills auto sequence, in other cases it does not. In certain cases, messages are sent while in

maintenance mode or when e-stop activated, in other cases they are not. In certain cases, alarms are generated in

maintenance mode, in other cases they are not.

This is due to lack of design media for maintenance mode operation.

\section{Exception Disposition :}

Make all automatic and maintenance mode operations and transitions consistent for all gloveboxes:

1. Transition from automatic to maintenance mode "kills" any automatic sequence in progress, with the exception of vacuum generation.

2. Messages are sent regardless of maintenance or automatic mode condition.

\section{Exception Status :}

9-3-97-MPLane to review code, apply fixes as needed.

Exception Closed By :

Date :

\section{APPROVAL OF RESOLUTION}

Contractor Representative:

Date:

(Only as needed)

WMH Representative:

Additional Approval:

(Only as needed)

FDNW Representative:

Date: 
ATP_YN : Y

SW

Test : 13031A.85

Step : ALL

Equipment Tag \#: LT-09-202A, 203A, 202C
Exception :

Revision :

Date:

Specification Section : $\quad 13031$

Test Witness/Author :

Schneider

Test Operator:

Responsible Company: $\quad$ WMH
Responsible Subcontractor:
Responsible Individual:

\section{Exception Description :}

8-4-97 - MPL Make LLW Ifft table logic like TRU lift table logic. If M/O/N switch is switched to maint, stop entry and exit sequences. Once placed into normal, operator can restart sequence by selecting appropriate OlU button.

\section{Exception Disposition :}

8-4-97-MPL Make operation consistent for allift tables.

\section{Exception Status :}

9-3-97 Changes added to 102 by Mike Schneider. MP Lane to retest.

Exception Closed By :

Date :

\section{APPROVAL OF RESOLUTION}

Contractor Representative:

(Only as needed)

Date:

WMH Representative:

Date:

Additional Approval:

(Only as needed).

Date:

Date: 
ATP_YN : $Y$

SW

Test : 13021A.86.1

Step : ALL
Exception :

Revision :

Date:

Specification Section : 13021

Test Witness/Author:

Warménhoven

Test Operator:

Responsible Company:

WMH

Responsible Subcontractor:

Responsible Individual:

Lane

Exception Description :

8-4-97-THIS APPLIESTO ALL OIUS:

MPL OIU locks up in alarms screen. N50:2/1 inner drum id veriified bit reset, movement between screens restored.

Exception Disposition :

8-4-97-MPL Fix if.

\section{Exception Status :}

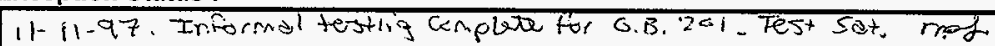

Exception Closed By :

\section{Glovebox zol onily prefs}

Date: $11-1+97$

\section{APPROVAL OF RESOLUTION}

Contractor Representative:

(Only as needed)

Date:

WMH Representative:

Date:

Additional Approval:

(Only as needed)

Date:

Date: 
ATP YN : Y

SW

Test : 13031 A.85

Step : All

Equipment Tag \#: All

\section{Exception :}

Revision :

Date:

Specification Section :

13031

Test Witness/Author :

Lane

Test Operator:

Responsible Company: WMH
Responsible Subcontractor:
Responsible Individual: Lane

Exception Description :

E-Stop - entry/exit lift table sequences, hoist seq., conveyer seq. - E-Stop doesn't prevent sequence from starting.

\section{Exception Disposition :}

9-3-97 MP Lane to fix, retest.

\section{Exception Status :}

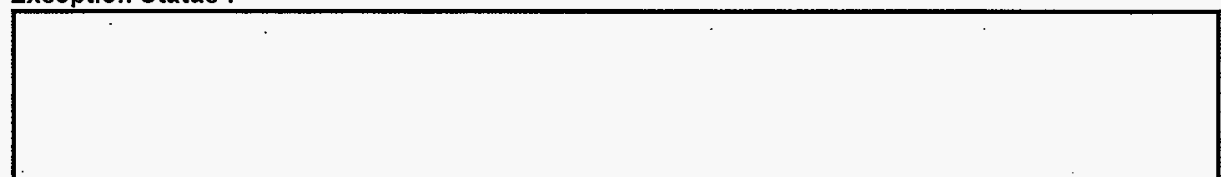

Exception Closed By :

Date :

\section{APPROVAL OF RESOLUTION}

Contractor Representative:

(Only as needed)

Date:

WMH Representative:

Date:

Additional Approval:

(Only as needed)

Date:

Date: 
ATP_YN : Y

SW

Test : 13031A-85

Step :

Equipment Tag \#: 104-CNR-12-102,-103
Exception :

Revision :

Date:

Specification Section :

13031

Test Witness/Author:

\section{Warmenhoven}

Test Operator:

Responsible Company: WMH

Responsible Subcontractor:

Responsible Individual: Lane

\section{Exception Description :}

Ladder logic rung comments don't match code, E-stop contacts mislabeled.

Exception Disposition :

FIX ladder logic symbols, descriptions, rung comments.

\section{Exception Status :}

$11-11-97-$ compuad for file 45 cinly prob

Exception Closed By :

Date: $11-11-97$

$$
\text { mof. }
$$

\section{APPROVAL OF RESOLUTION}

Contractor Representative:

(Only as needed)

Date:

WMH Representative:

Date:

Additional Approval:

(Only as needed)

Date:

FDNW Representative:

Date: 
TEST PROCEDURE APPROVED FOR USE:

\begin{tabular}{|l|l|l|}
\hline \multicolumn{2}{|l|}{ Test Procedure: 13027A-87 } & Title: LLW RWM GLOVEBOX (GB-07-201) ACCEPTANCE TEST \\
\hline Revision: 1 & Execution: & Test Director Signature: \\
\hline
\end{tabular}

Location: Buyer's Plant/Field Date/Time: Start:

Test Operator: Michail P L-ane.
End:

\begin{tabular}{|l|l|l|}
\hline Test Exceptions Recorded? $\quad$ ¿Yes $\quad \square$ No \\
\hline COMMENTS: & \\
\hline
\end{tabular}

\section{TEST PROCEDURE COMPLETION APPROVAL:}

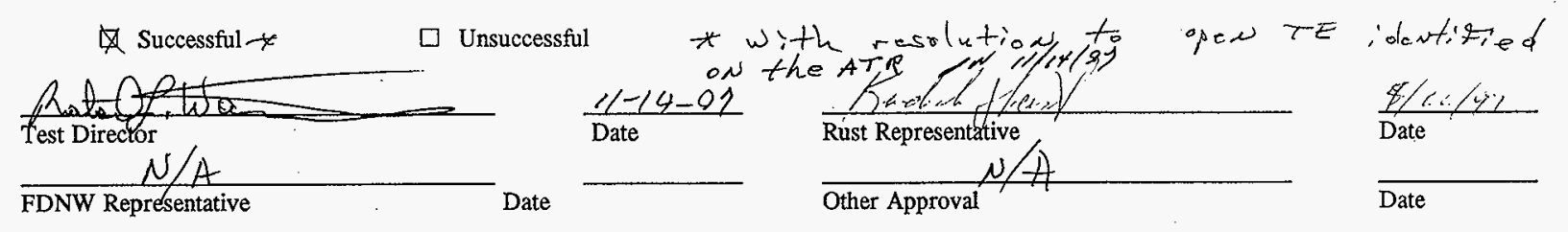

\section{CERTIFICATION OF SATISFACTORY EXECUTION}

All of the test cases for this test procedure have been tested and all exception sheets for this test case have been closed or resolved.

$$
N / A
$$

FDNW Representative

\section{Date}

Page 1 of 1 


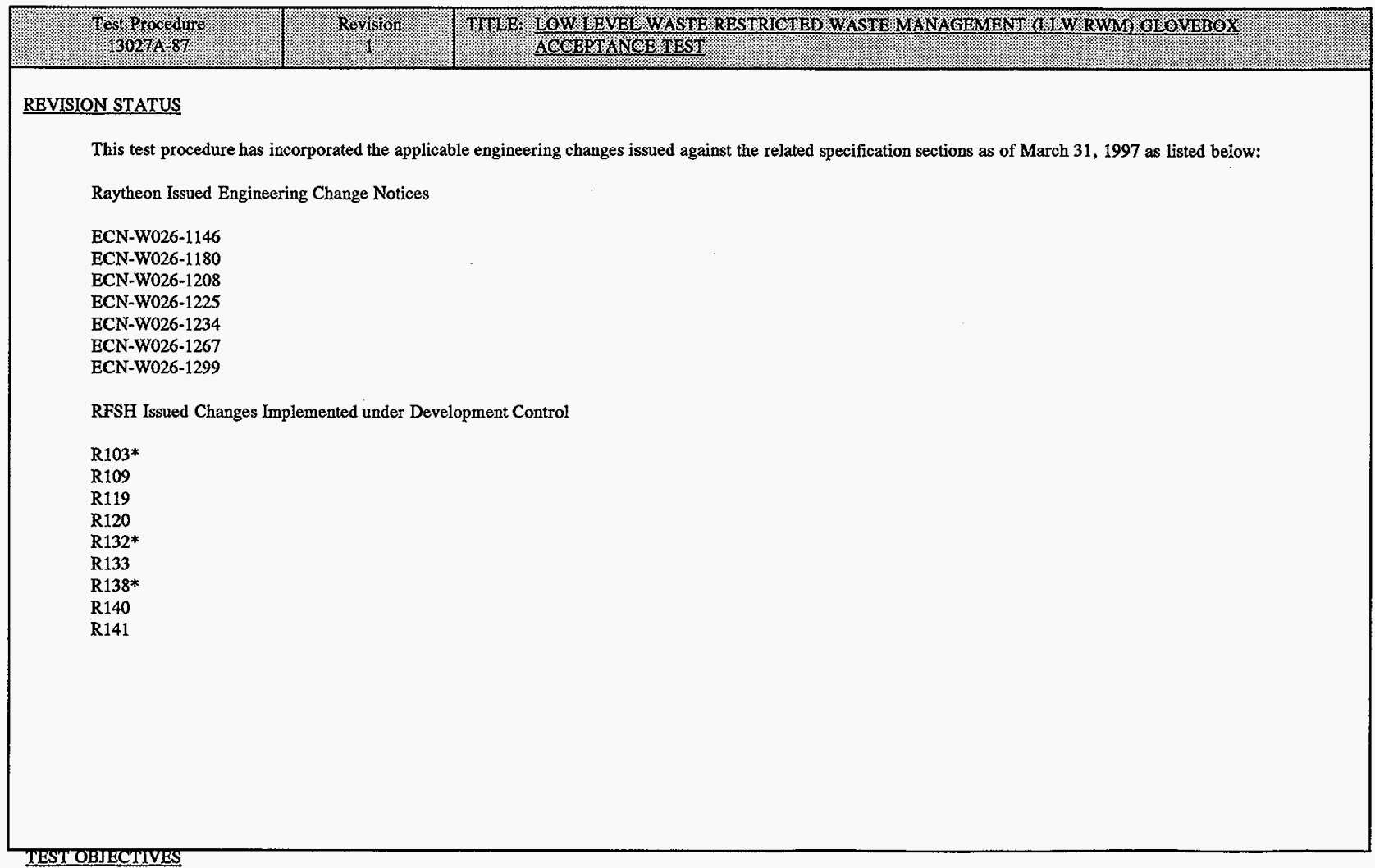


Test Procedure: $13027 \% 8 \%$
$\mathrm{Re}$ rision $2 \%$
101.6

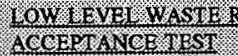

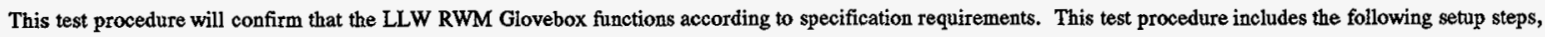
shutdown steps, data sheets, and test cases:

TEST PROCEDURE 13027A-87 SETUP

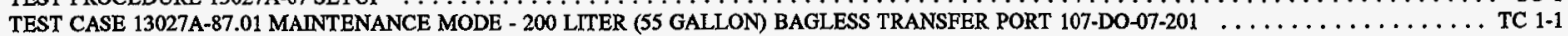

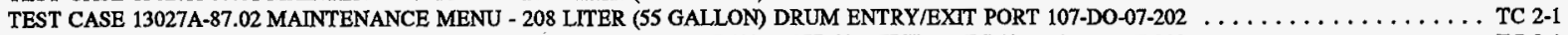

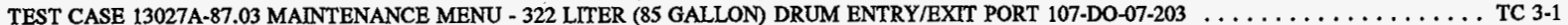

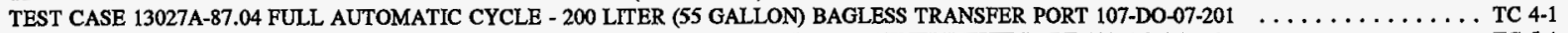

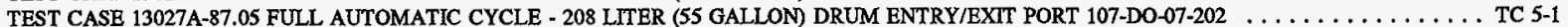

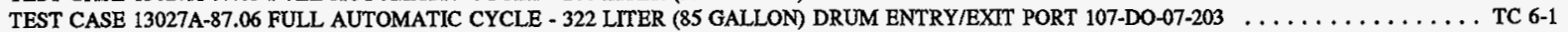

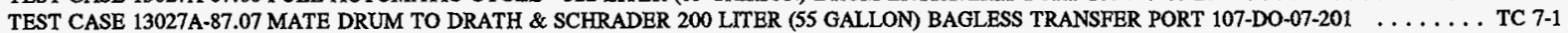

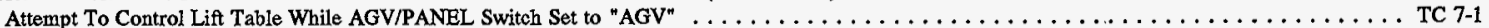

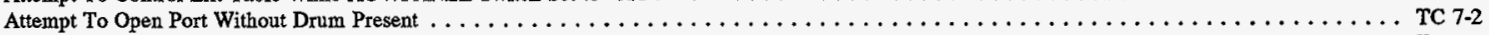

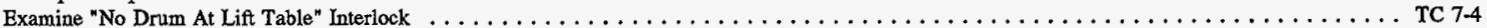

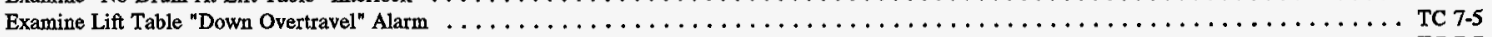

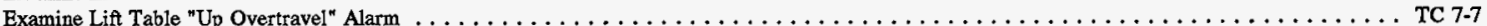

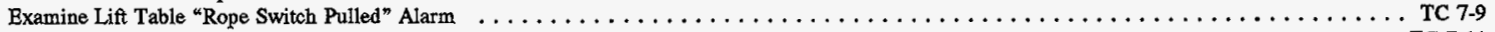

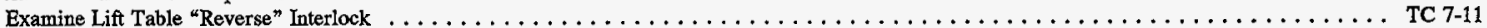

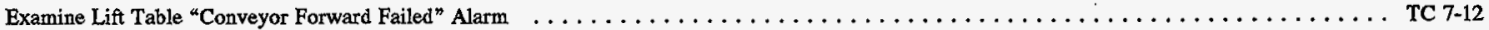

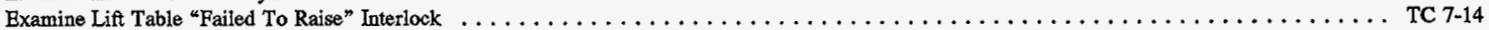
Examine Lift Table Weight/Pressure Changes When Port Opened and Closed . . . . . . . . . . . . . . . . . . . . . . TC 7-15

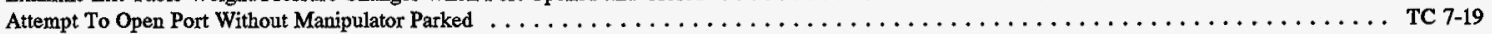

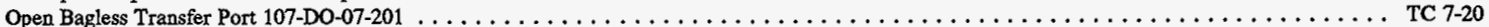

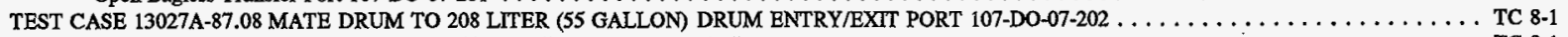
Attempt To Control Lift Table While AGV/PANEL Switch Set to "AGV" . . . . . . . . . . . . . . . . . . . . . . . . TC 8-1

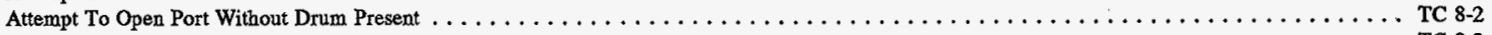

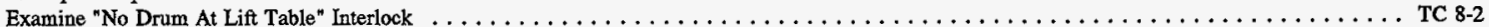
Examine Lift Table "Down Overtravel" Alarm . . . . . . . . . . . . . . . . . . . . . . . . . . . . . . . . . TC 8.5 Examine Lift Table "Up Overtravel" Alarm . . . . . . . . . . . . . . . . . . . . . . . . . . . . . . . . . TC 8-7

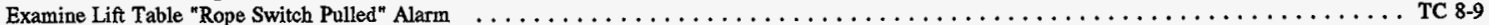

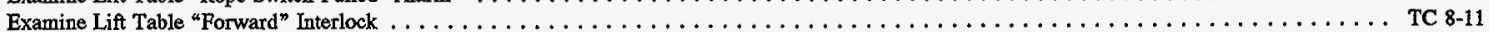

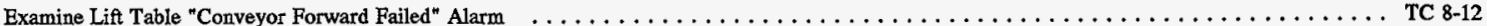

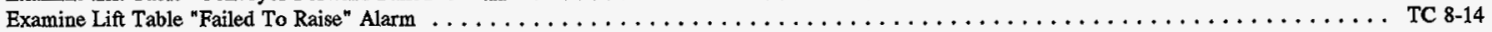
Attempt To Open Port Without Manipulator Parked $\ldots \ldots \ldots \ldots \ldots \ldots \ldots \ldots$

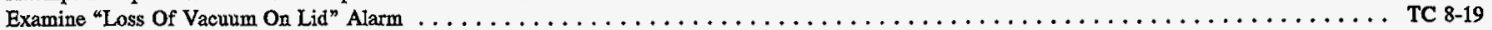
Examine "Door In Position" and "Door Rotated" Interlocks . . . . . . . . . . . . . . . . . . . . . . . . . . . TC 8-23 
Open 208 Liter (55 Gallon) Entry/Exit Port DO-07-202

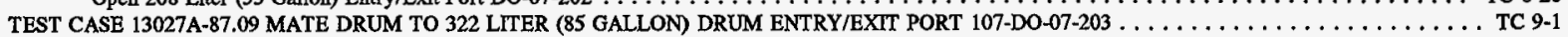

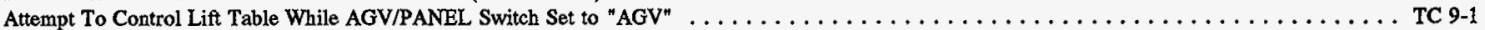

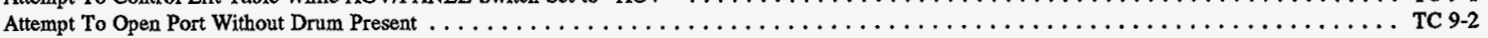

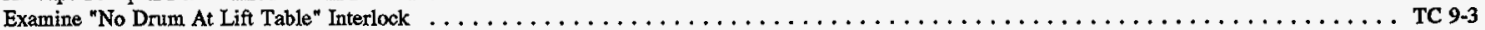

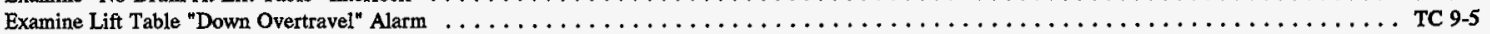

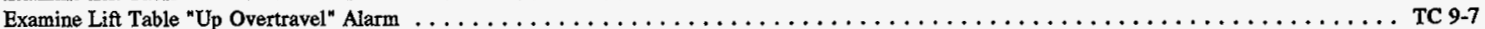

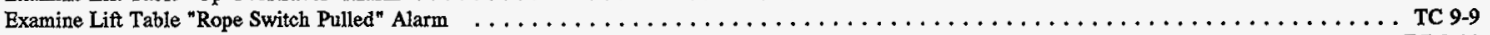

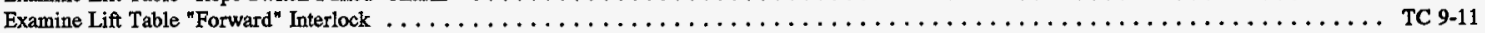

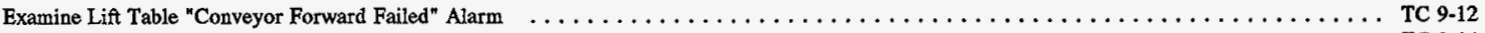

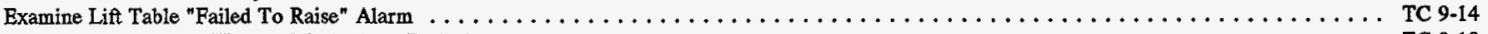

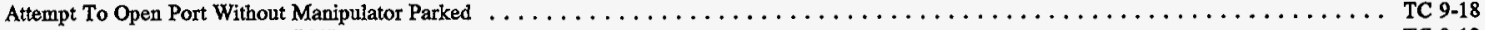

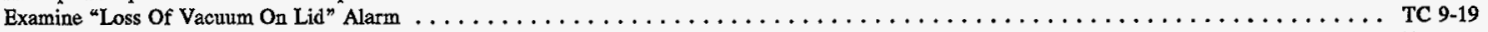

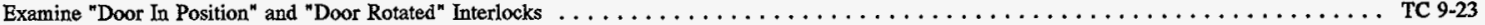

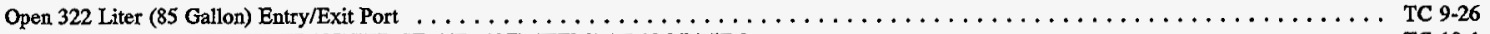

TEST CASE 13027 A-87.10 REMOVE TRANSFER STAND AND ITEMS FROM DRUM $\ldots \ldots \ldots \ldots \ldots \ldots \ldots \ldots \ldots \ldots \ldots \ldots \ldots \ldots \ldots$

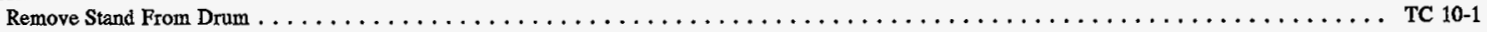

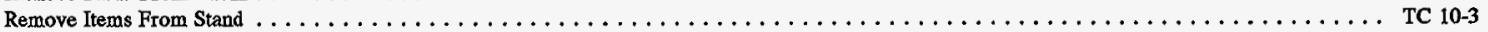

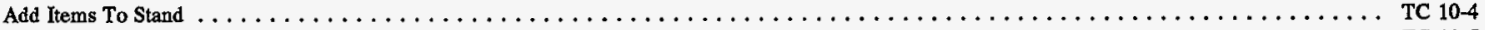

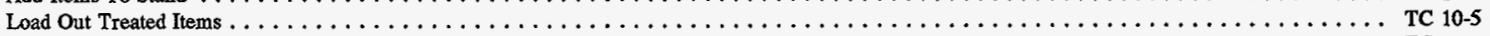

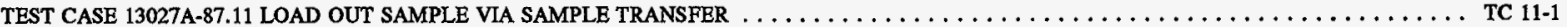

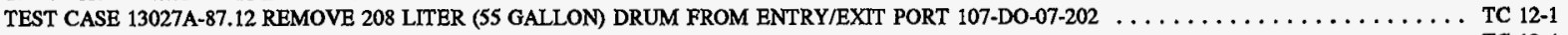

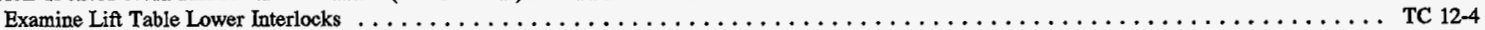

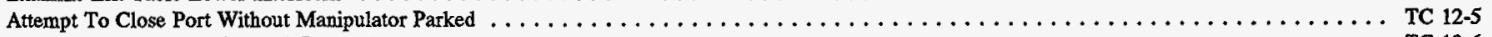

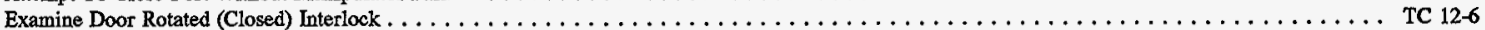

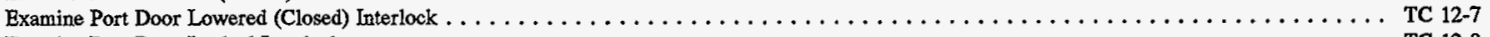

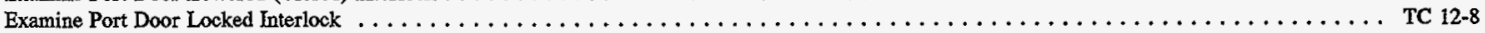

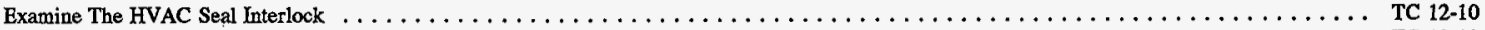

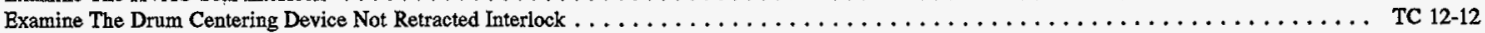

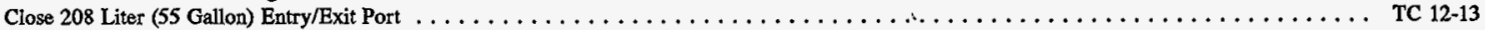

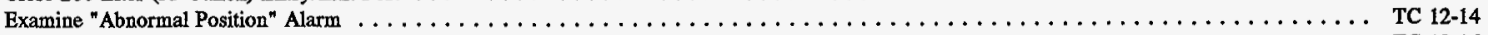

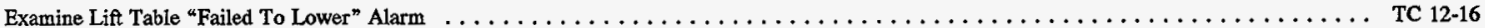

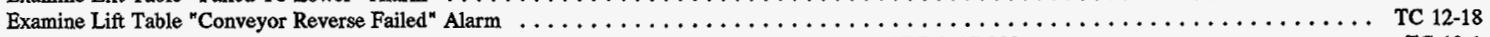

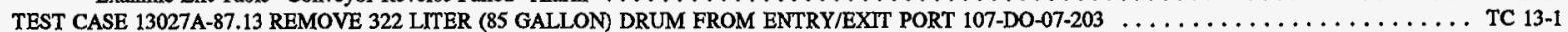

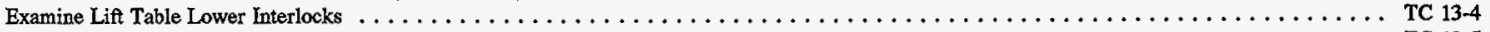

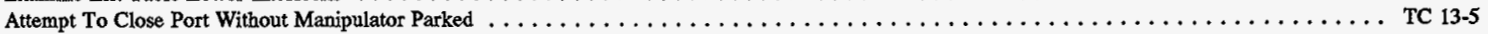




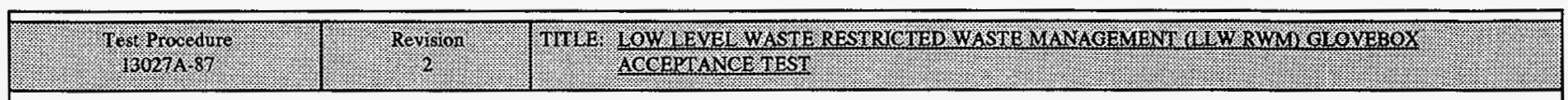

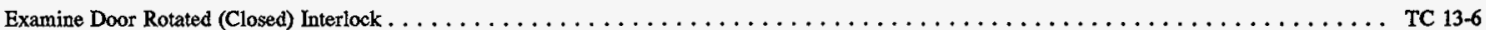

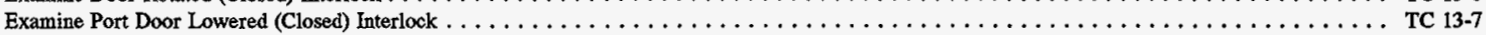

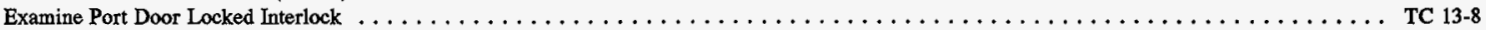

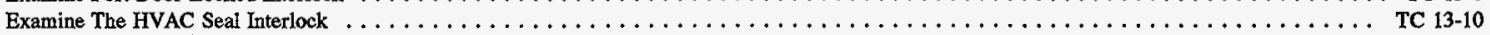

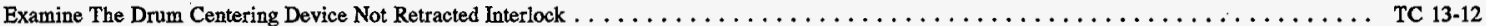

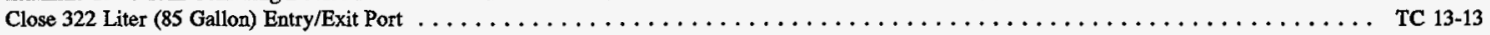

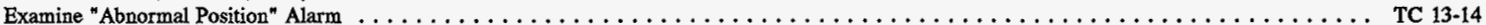

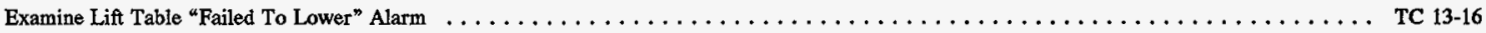

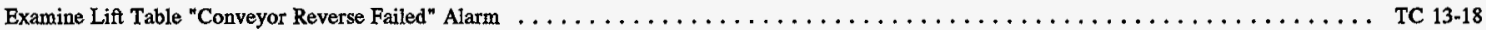

TEST CASE 13027A-87.14 RETURN NON-COMPLIANT ITEM TRANSFER STAND TO DRUM PORT 107-DO-07-201 . . . . . . . . . . . . TC 14-1

TEST CASE 13027A-87.15.07 REMOVE 200 LITER (55 GALLON) DRUM FROM BAGLESS TRANSFER PORT 107-D0-07-201 . . . . . . . . . . TC 15-1

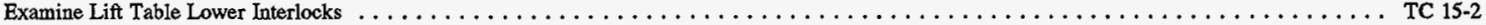

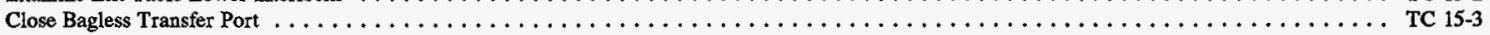

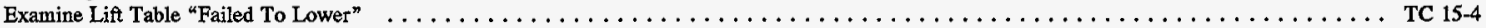

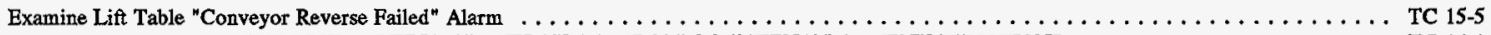

TEST CASE 13027A-87.16 EXAMINE LLW SORTING GLOVEBOX (GB-07-201) MAINTENANCE MENU FUNCTIONS . . . . . . . . . . . TC 16-1

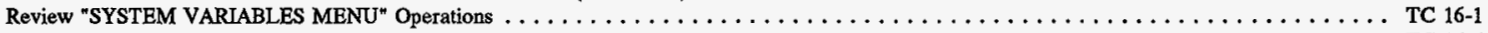

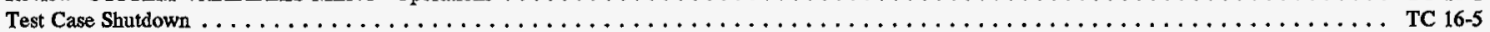

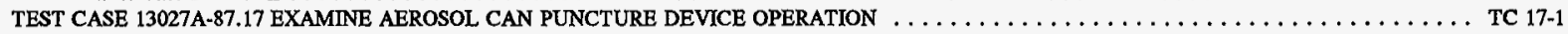

TEST CASE 13027A-87.18 EXAMINE "REHOME" FUNCTION OF LIFT TABLE 107-LT-09-201D . . . . . . . . . . . . . . . . . TC 18-1

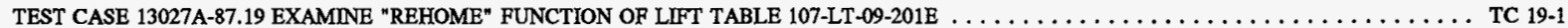

TEST CASE 13027A-87.20 EXAMINE "REHOME" FUNCTION OF LIFT TABLE 107-LT-09-201F . . . . . . . . . . . . . . . . . . TC 20-1

TEST CASE 13027A-87.21 FULL AUTOMATIC CYCLE - 200 LITER (55 GALLON) BAGLESS TRANSFER PORT 107-DO-07-201 . . . . . . . . . . TC 21-1

TEST CASE 13027A-87.22 FULL AUTOMATIC CYCLE - 208 LITER (55 GALLON) DRUM ENTRY/EXIT PORT 107-DO-07-202 . . . . . . . . . TC 22-1

TEST CASE 13027A-87.23 FULL AUTOMATIC CYCLE - 322 LITER (85 GALLON) DRUM ENTRY/EXIT PORT 107-DO-07-203 . . . . . . . . . . . . TC 23-1

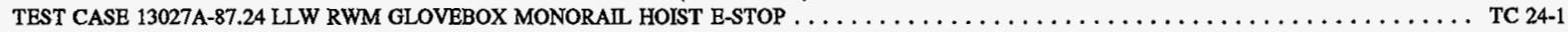

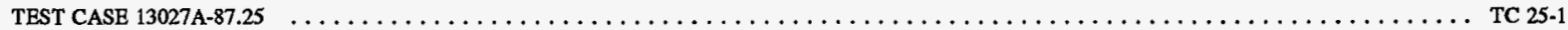

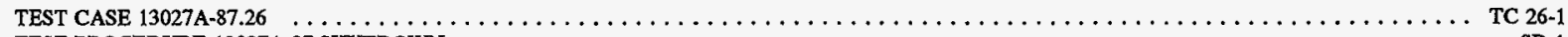

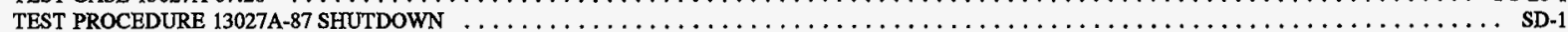

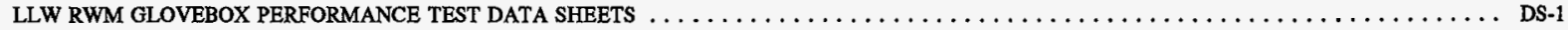


HNF-SD-W026-ATR-021 Rev. 1

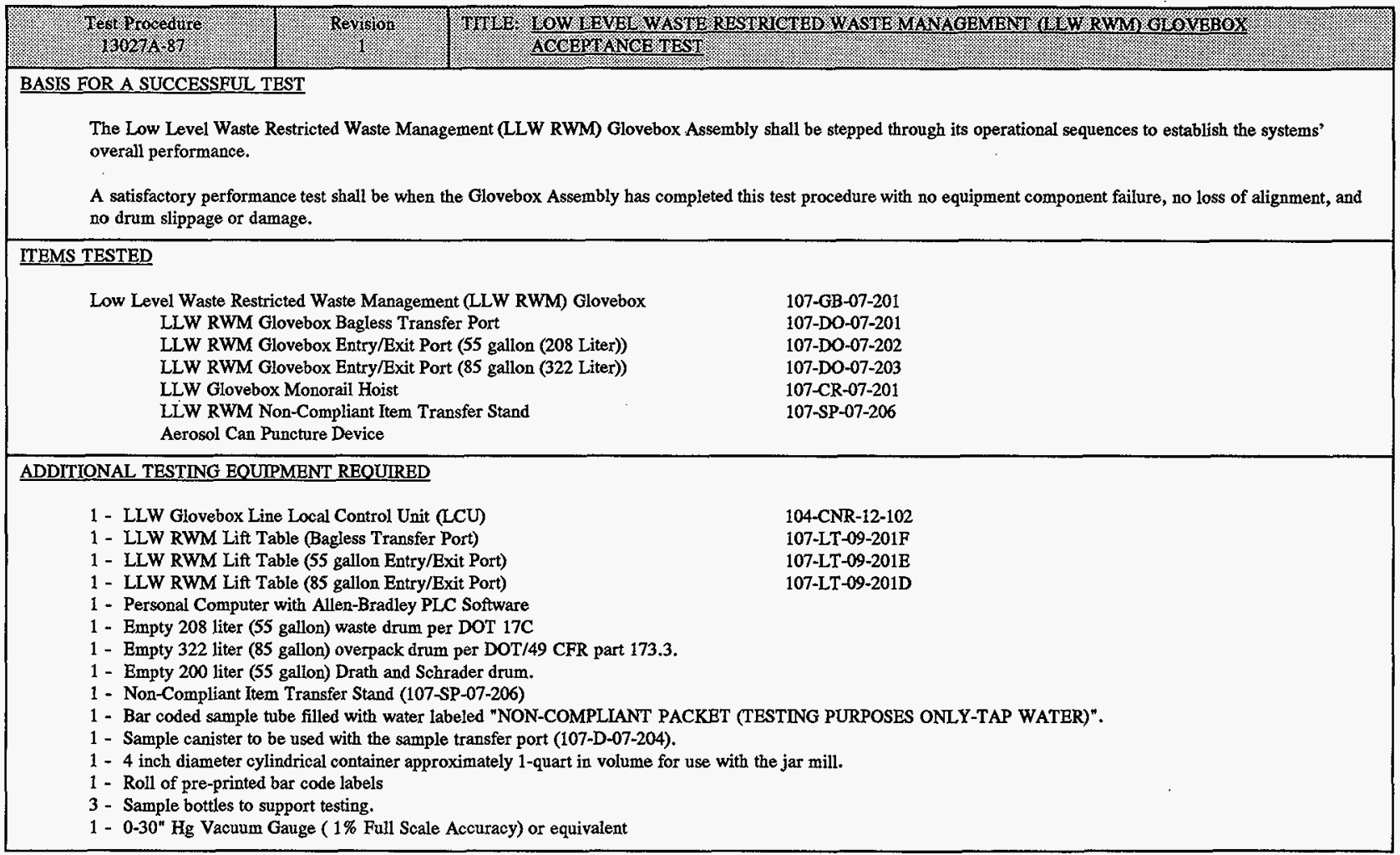


HNF-SD-W026-ATR-021 Rev. 1

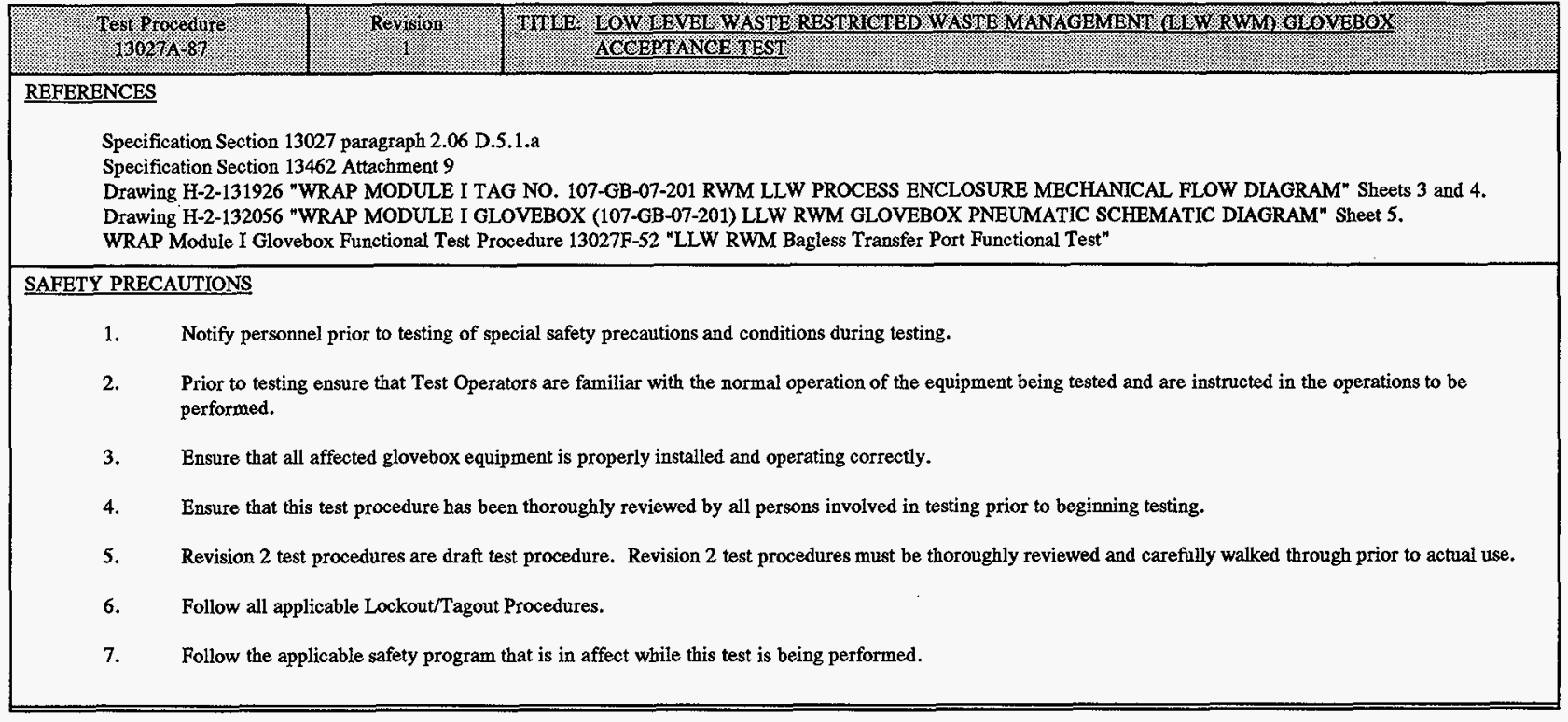


HNF-SD-W026-ATR-021 Rev. I

\begin{tabular}{|c|c|c|c|c|c|}
\hline Sien: & TEST PROCEDURE STERS & 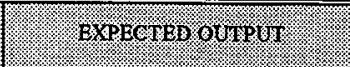 & Pass & 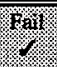 & (ivitivi) \\
\hline & 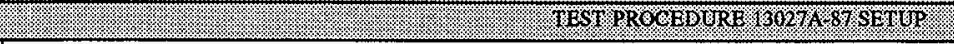 & & & & \\
\hline 1 & $\begin{array}{l}\text { Sign in the space provided below to confirm that all mechanical equipment, electrical wiring, } \\
\text { hydraulic, pneumatic, and sensor and control systems used in testing have been inspected and tested for } \\
\text { correct installation and safe operation prior to beginning testing using this test procedure. } \\
\text { Test Director: }\end{array}$ & & i) & & \\
\hline \multicolumn{6}{|c|}{ NOTE: } \\
\hline 2 & $\begin{array}{l}\text { INSTRUMENT AIR SYSTEM: } \\
\text { The Instrument Air System should be in operation. } \\
80 \text { psi present at glovebox. }\end{array}$ & $\begin{array}{l}\text { Verify that the Instrument Air } \\
\text { System is in operation. }\end{array}$ & 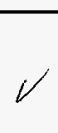 & & \\
\hline 3 & $\begin{array}{l}\text { PLANT ELECTRICAL SYSTEM: } \\
\text { Motor Control Center MCC-09-102 should be energized }\end{array}$ & $\begin{array}{l}\text { Verify that Motor Control Center } \\
\text { MCC-09-102 is energized. }\end{array}$ & $v$ & & \\
\hline 4 & $\begin{array}{l}\text { The following supply breakers at MCC-09-102 should be closed. If they are not, close the breakers. } \\
\begin{array}{ll}\text { Bift Table LT-201D Conveyor motor. } & \text { Breaker Label } \\
\text { Lift Table LT-201E Conveyor motor. } & \text { LT-09-201D } \\
\text { Lift Table LT-201F Conveyor motor. } & \text { LT-09-201F } \\
\text { Power Panel PP-09-103. } & \text { PP-09-103 }\end{array}\end{array}$ & $\begin{array}{l}\text { Verify that the breakers at MCC-09- } \\
102 \text { are closed. }\end{array}$ & $c$ & & \\
\hline 5 & $\begin{array}{l}\text { The following supply breakers at PP-09-103 should be closed. If they are not, close the breakers. } \\
\begin{array}{ll}\text { Bkr. } 29 & \text { Lift Table 201D lift motor and control circuit. } \\
\text { Bkr. } 31 & \text { Lift Table 201E lift motor and control circuit. } \\
\text { Bkr. } 28 & \text { Lift Table 201F lift motor and control circuit. }\end{array}\end{array}$ & $\begin{array}{l}\text { Verify that the supply breakers at } \\
\text { PP-09-103 are closed. }\end{array}$ & $\checkmark$ & & \\
\hline 6 & LCU 104-CNR-12-102 should be energized. & $\begin{array}{l}\text { Verify that LCU 104-CNR-12-102 is } \\
\text { energized. }\end{array}$ & 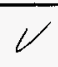 & & \\
\hline 7 & $\begin{array}{l}\text { FIRE DETECTION SYSTEM: } \\
\text { The Fire Detection System interface from the LLW RWM Glovebox should be disabled by the Fire } \\
\text { Department. }\end{array}$ & $\begin{array}{l}\text { Verify that the Fire Detection System } \\
\text { interface from the LLW RWM } \\
\text { Glovebox has been disabled by the } \\
\text { Fire Department. }\end{array}$ & $V$ & & \\
\hline
\end{tabular}


HNF-SD-W026-ATR-021 Rev. 1

\begin{tabular}{|c|c|c|c|c|c|}
\hline Step & 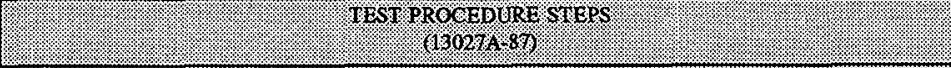 & 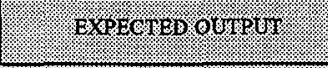 & a.t. & t.8. & (rintivit) \\
\hline & 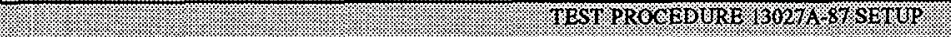 & & & & \\
\hline 8 & $\begin{array}{l}\text { FIRE SUPPRESSTON SXSTEM: } \\
\text { The Fire Suppression System interface from the LLW RWM Glovebox should be disabled by the Fire } \\
\text { Department. }\end{array}$ & $\begin{array}{l}\text { Verify that the Fire Suppression } \\
\text { System interface from the LLW } \\
\text { RWM Glovebox has been disabled } \\
\text { by the Fire Department. }\end{array}$ & & & \\
\hline 9 & $\begin{array}{l}\text { Visually inspect the LLW RWM Glovebox area. Confirm that the LLW RWM Glovebox (107-GB-07- } \\
\text { 201) and all items associated with this glovebox are ready for operation and that no debris or other } \\
\text { foreign matter is present that would disrupt testing. }\end{array}$ & $\begin{array}{l}\text { Verify that the LLW RWM } \\
\text { Glovebox has been prepared for } \\
\text { operation and testing. }\end{array}$ & & & \\
\hline 10 & $\begin{array}{l}\text { Review the basis for successful completion of this test procedure. } \\
\text { This test procedure consists of multiple test cases. Each test case tests a particular equipment item or } \\
\text { feature of the LLW RWM Glovebox. } \\
\text { If a test case is completed without exceptions, it is said to be completed in one "execution". If errors } \\
\text { are found during the execution, the "test case execution" must be started over from the beginning and } \\
\text { will require additional "executions" until it is completed without errors. } \\
\text { The test procedure is considered successfully completed when all test cases have been executed without } \\
\text { exceptions. }\end{array}$ & $\begin{array}{l}\text { Verify that the test procedure has } \\
\text { been reviewed prior to testing. }\end{array}$ & & & \\
\hline 11 & $\begin{array}{l}\text { Review the conventions used in this test procedure. } \\
\text { This procedure contains several references to the "PCS" or "Plant Control System". This is the } \\
\text { generic term applied to the computer hardware and software that supports glovebox operation. } \\
\text { Local Control Units or "LCUs" are microprocessor devices that are an integral part of the PCS, and } \\
\text { are used to status and control glovebox devices. } \\
\text { Operator Interface Units or "OIUs" are display panels connected to the LCU's. The OIUs allow } \\
\text { operators to start processing sequences, activate or shutdown glovebox devices, and process glovebox } \\
\text { alarms. }\end{array}$ & $\begin{array}{l}\text { Verify that the test procedure } \\
\text { conventions have been reviewed } \\
\text { prior to testing. }\end{array}$ & & & \\
\hline
\end{tabular}


HNF-SD-W026-ATR-021 Rev. 1

\begin{tabular}{|c|c|c|c|c|c|}
\hline Siep & (1) TESTPROCEDGRE STEPS & EXPECTEP GAYTPR & rasis. & Far. & (initines \\
\hline S. & \multicolumn{5}{|l|}{ 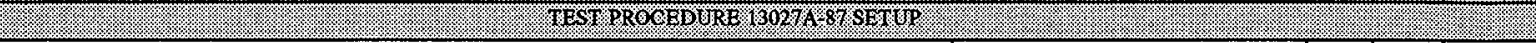 } \\
\hline 12 & $\begin{array}{l}\text { Review the conventions used in this test procedure (cont). } \\
\text { Every item listed in the "EXPECTED OUTPUT" column must be verified by the test witness for each } \\
\text { procedure step. In many cases, multiple expected outputs must be verified for a single test procedure } \\
\text { step. } \\
\text { If the actual output of the test step matches the expected output for the test step, the test witness should } \\
\text { place a check in the "PASS" column and initial the witness column. If the actual output of the test } \\
\text { step significantly differs from expected output for the test step, the test witness should place a check in } \\
\text { the "FAII" column and initial the witness column. Any test procedure step that "fails" when actual } \\
\text { output does not substantially match expected output is considered a test exception. Test exceptions are } \\
\text { resolved by the test director with concurrence from the test operator and test witness. } \\
\text { Any test procedure step that "fails" due to test procedure clerical error is not considered a test } \\
\text { exception. Test procedure clerical errors will be corrected by ink modification, initialed and dated, of } \\
\text { the test procedure during testing. }\end{array}$ & $\begin{array}{l}\text { Verify that the test procedure } \\
\text { conventions have been reviewed } \\
\text { prior to testing. }\end{array}$ & & & \\
\hline
\end{tabular}


HINP-SD-W026-ATR-021 Rev. 1

\begin{tabular}{|c|c|c|c|c|c|}
\hline Step. & 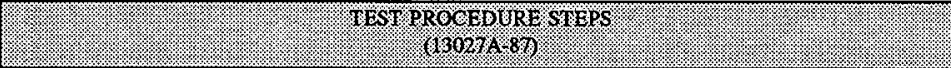 & PXPEGIEP OUYTOU & $\sqrt{96}$ & fiall & Witivess \\
\hline & 列 & & & & \\
\hline 13 & $\begin{array}{l}\text { Review the conventions used in this test procedure (cont). } \\
\text { The convention used for switch states is "activated" and "not activated". An "activated" switch is a } \\
\text { functioning switch that is depressed, illuminated, or provides electrical continuity or is otherwise } \\
\text { actuated. A "not activated" switch is a functioning switch that is not depressed, not illuminated, does } \\
\text { not provide electrical continuity, or is otherwise not actuated. Typically, vacuum switches are } \\
\text { described as "activated" when vacuum is present and "not activated" when vacuum is not present. } \\
\text { Pressure switches are typically described as "activated" when pressure is present and "not activated" } \\
\text { when pressure is not present. } \\
\text { LCU register status directly corresponds to switches and other sensors that are activated (STATUS = } \\
\text { "1") or not activated (STATUS = "0"). LCU registers are forced activated or forced not activated } \\
\text { using Allen Bradley PLC software. } \\
\text { The Allen Bradley PLC software will be used to confirm the status of each switch and sensor examined } \\
\text { during this test procedure. } \\
\text { When a procedure step requests that a switch status be forced or confirmed as either "activated" or } \\
\text { "not activated", the switch register will be examined using the PLC software. If the register status is } \\
\text { "1", the switch or sensor is considered "activated". If the register status is "0", the switch or sensor is } \\
\text { considered "not activated". }\end{array}$ & $\begin{array}{l}\text { Verify that the test procedure } \\
\text { conventions have been reviewed } \\
\text { prior to testing. }\end{array}$ & $\checkmark$ & & \\
\hline 14 & $\begin{array}{l}\text { Review the conventions used in this test procedure (cont). } \\
\text { Due to the current status of glovebox bar code operations, the bar code portions of this test will only } \\
\text { be performed if all required bar code changes have been implemented. If bar code changes have not } \\
\text { been fully implemented at the time that this test procedure is run, the appropriate status registers will } \\
\text { be modified/forced to support test operations, and an additional test will be required to confirm correct } \\
\text { bar code system operation. } \\
\text { Record the status of the glovebox bar code systems below. } \\
\text { Will Glovebox Bar Code Systems be tested as part of this test (YES/NO)? } \\
\text { (W) }\end{array}$ & $\begin{array}{l}\text { Verify that the bar code system } \\
\text { status is recorded. }\end{array}$ & & & \\
\hline
\end{tabular}




\begin{tabular}{|c|c|c|c|c|c|}
\hline & & & 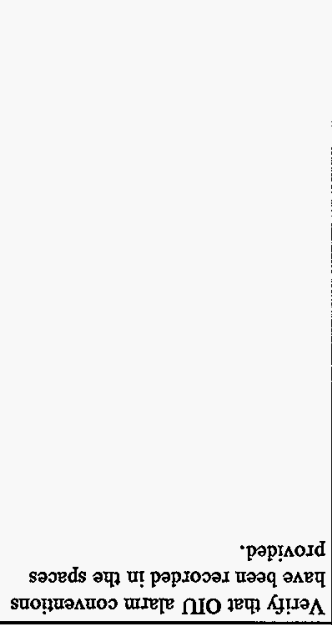 & 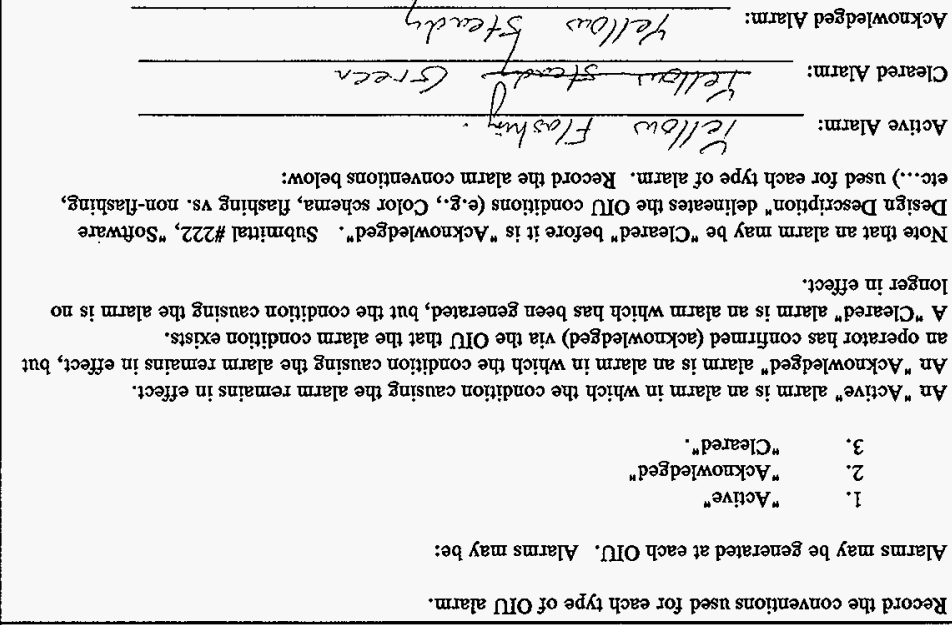 & 91 \\
\hline & & & 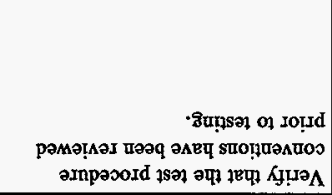 & 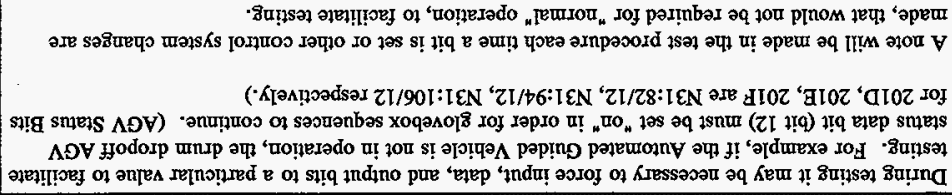 & SI \\
\hline & & & & 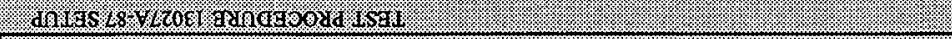 & \\
\hline (c) & 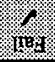 & Why & 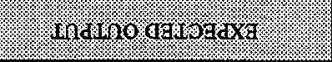 & 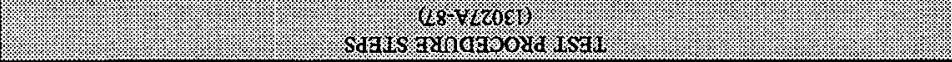 & dist \\
\hline
\end{tabular}


HNF-SD-W026-ATR-021 Rev. 1

\begin{tabular}{|c|c|c|c|c|c|}
\hline Stex & P. & 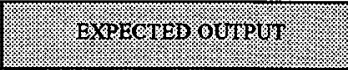 & (p) & 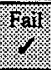 & Witivess \\
\hline \multicolumn{6}{|c|}{ 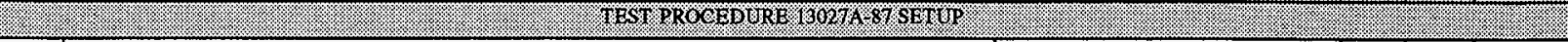 } \\
\hline 17 & $\begin{array}{l}\text { Prepare the following lift tables to support testing: } \\
\text { LIFT TABLE } \\
\text { 107-LT-09-201D 107-DO-07-203 LLW RWM } 85 \text { gallon Entry/Exit } \\
\text { 107-LT-09-201E 107-DO-07-202 LLW RWM } 55 \text { gallon Entry/Exit } \\
\text { 107-LT-09-201F 107-DO-07-201 LLW RWM Bagless Transfer Port } \\
\text { Batastrets-ate } \\
\text { points are available and correctly labeled. }\end{array}$ & $\begin{array}{l}\text { Verify that lift table equipment } \\
\text { items, inputs, outputs, and OIU } \\
\text { points are available and correctly } \\
\text { labeled. }\end{array}$ & & & \\
\hline 18 & $\begin{array}{l}\text { Prepare one empty } 208 \text { liter ( } 55 \text { gallon) waste drum per DOT 17C. The band clamp should be } \\
\text { removed from this drum. }\end{array}$ & $\begin{array}{l}\text { Verify that an empty waste drum is } \\
\text { available for testing. }\end{array}$ & & & \\
\hline 19 & $\begin{array}{l}\text { Prepare one empty } 322 \text { liter (85 gallon) overpack drum per DOT/49 CFR part 173.3. } \\
\qquad B_{06} 6 \text { cock }\end{array}$ & $\begin{array}{l}\text { Verify that an empty overpack drum } \\
\text { is available for testing. }\end{array}$ & & & \\
\hline 20 & $\begin{array}{l}\text { Prepare one empty } 200 \text { liter ( } 55 \text { gallon) Drath-and-Schraderdrum. This type of drum is designed to } \\
\text { function with the LLW RWM Bagless Transfer Port (107-DO-07-201). The Drath and Schrader drum } \\
\text { should be equipped with an inner drum lid, and a Non-Compliant Item Transfer Stand (107-SP-07- } \\
\text { 206). }\end{array}$ & $\begin{array}{l}\text { Verify that a Drath and Schrader } \\
\text { drum with inner lid and transfer } \\
\text { stand is available for testing. }\end{array}$ & & & \\
\hline 21 & $\begin{array}{l}\text { Provide one sample canister to be used with the sample transfer port (107-D-07-204). Several sample } \\
\text { tubes which fit inside the canister should be available to support testing. }\end{array}$ & $\begin{array}{l}\text { Verify that a sample canister with at } \\
\text { least two sample tubes is available } \\
\text { for testing. }\end{array}$ & & & \\
\hline 22 & Unforce all LCU 102 registers using the Allen Bradley PLC Software. & $\begin{array}{l}\text { Verify that all LCU } 102 \text { registers are } \\
\text { unforced. }\end{array}$ & & & \\
\hline 23 & $\begin{array}{l}\text { NOTE: The manipulator serves as an interlock for Bagless Transfer Port operation. When a drum is } \\
\text { mated to the port and the manipulator is at the park position, the Bagless Transfer Port should } \\
\text { not be prevented from opening. } \\
\text { Place the LLW RWM Waste Manipulator (107-EM-07-201) at park position 2, farthest from Bagless } \\
\text { Transfer Port (107-DO-07-201) with both manipulator arms fully parked. }\end{array}$ & $\begin{array}{l}\text { Visually verify that the manipulator } \\
\text { is at park position } 2 \text { with both arms } \\
\text { parked. }\end{array}$ & & & \\
\hline
\end{tabular}


HNF-SD-W026-ATR-021 Rev. 1

\begin{tabular}{|c|c|c|c|c|c|}
\hline Step & TIST PROGED URE STERS & 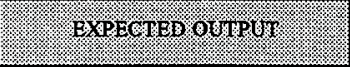 & Pros & Earit & $\begin{array}{l}\text { Wininess } \\
\text { (nitialy }\end{array}$ \\
\hline \multicolumn{6}{|c|}{ R. } \\
\hline 24 & $\begin{array}{l}\text { Place the Glovebox Monorail Hoist pendant 107-PC-07-009A "Pendant Select" switch to the "PEND } \\
\text { A" position. } \\
\text { The enabled indicator on "PEND A" should be illuminated. }\end{array}$ & $\begin{array}{l}\text { Verify that the 107-PC-07-009A } \\
\text { hoist pendant "Pendant Select" } \\
\text { switch is placed in the "PEND A" } \\
\text { position. } \\
\text { Verify that the "ENABLED" } \\
\text { indicator is illuminated. }\end{array}$ & & & \\
\hline 25 & $\begin{array}{l}\text { Confirm that the LLW RWM Glovebox Monorail Hoist (107-CR-07-201) is unloaded (no transfer } \\
\text { stand attached) and fully raised. If necessary, unload the hoist and use the hoist/trolley pendant (107- } \\
\text { PC-07-009A) to fully raise the hoist. } \\
\text { The hoist "RAISED LIMTT" indicator should be illuminated, indicating that the hoist is fully raised. }\end{array}$ & $\begin{array}{l}\text { Visually verify that the hoist is } \\
\text { unloaded (no transfer stand attached) } \\
\text { and fully raised. } \\
\text { Verify that hoist "RAISED LIMIT" } \\
\text { indicator is illuminated. }\end{array}$ & & & \\
\hline 26 & $\begin{array}{l}\text { NOTE: For testing purposes, the park position for the hoist will be over the Bagless Transfer Port. } \\
\text { Movement toward this position will be referred to as "forward" ("LEFT" indicator on } \\
\text { "PEND A or B") and movement away from this position will be referred to as "reverse" } \\
\text { ("RIGHT" indicator on "PEND A or B"). } \\
\text { Position the LLW RWM Glovebox Monorail Hoist (107-CR-07-201) directly over the Bagless Transfer } \\
\text { Port (107-DO-07-201). } \\
\text { The "LEFT" indicator on "PEND A" should be illuminated, indicating that the hoist is positioned over } \\
\text { the Bagless Transfer Port. }\end{array}$ & $\begin{array}{l}\text { Verify that the hoist is positioned } \\
\text { directly over the Bagless Transfer } \\
\text { Port (107-DO-07-201). } \\
\text { Verify that the "LEFT" indicator on } \\
\text { "PEND A" is illuminated. }\end{array}$ & & & \\
\hline 27 & $\begin{array}{l}\text { Set the Lift Table Local Control Pedestal M/O/N switches for all LLW RWM lift tables (ie., 107-LT- } \\
09-201 \mathrm{D}, 201 \mathrm{E} \text {, and 201F) to "MAINTENANCE" to allow an operator to activate and control each lift } \\
\text { table. }\end{array}$ & $\begin{array}{l}\text { Verify that the lift table M/O/N } \\
\text { switches are switched to the "M" } \\
\text { position (for "Maintenance") }\end{array}$ & $y$ & & \\
\hline 28 & $\begin{array}{l}\text { Set Lift Table Local Control Pedestal AGV/PANEL switches to "PANEL" for all LLW RWM lift } \\
\text { tables (ie., 107-LT-09-201D, 201E, and 201F) to allow an operator to activate and control each lift } \\
\text { table. }\end{array}$ & $\begin{array}{l}\text { Verify that each lift table } \\
\text { AGV/PANEL switch is switched to } \\
\text { the "PANEL" position (to allow } \\
\text { operator to control lift table from the } \\
\text { "PANEL") }\end{array}$ & $V$ & & \\
\hline
\end{tabular}


HNF-SD-W026-ATR-021 Rev. 1

\begin{tabular}{|c|c|c|c|c|c|}
\hline Ster. & 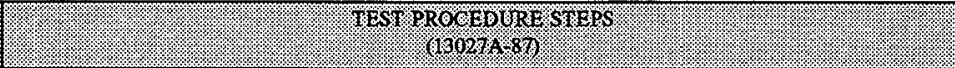 & EXPECTBD OUYP & pass. & 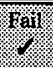 & (ritrines \\
\hline & 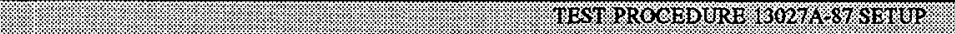 & & & & \\
\hline 29 & $\begin{array}{l}\text { Activate the lift table "LOWER" pushbutton at each LLW RWM Lift Table Local Control Pedestal to } \\
\text { lower the lift table to its lowered position } \\
\text { below AGV height (ie., 107-LT-09-201D, 201E, and 201F). } \\
\text { The "DOWN OVERTRAVEL" status indicator at each Lift Table Local Control Pedestal should not be } \\
\text { illuminated when the lift table is lowered. } \\
\text { Reterneet to A } 6 \mathrm{~V} \text { heych For } 201,202\end{array}$ & $\begin{array}{l}\text { Visually confirm that the lift tables } \\
\text { are lowered below AGV height. } \\
\text { Verify that the "DOWN } \\
\text { OVERTRAVEL" status indicator at } \\
\text { each Lift Table Local Control } \\
\text { Pedestal is not illuminated. }\end{array}$ & & & \\
\hline 30 & 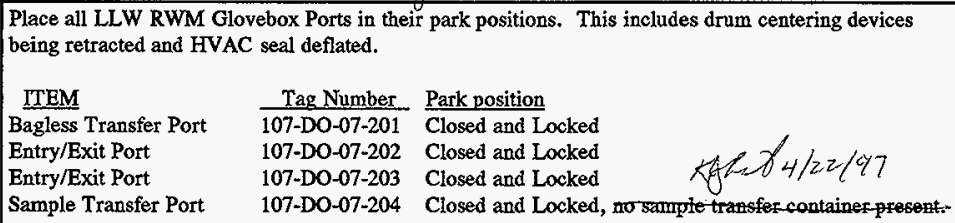 & $\begin{array}{l}\text { Verify that all glovebox ports have } \\
\text { been placed in their park positions. }\end{array}$ & & & \\
\hline 31 & $\begin{array}{l}\text { The LLW RWM Bagless Transfer Port requires that the port load cell indicate that predetermined } \\
\text { weight set point has been reached before the port is enabled for operation. } \\
\text { Record the weight set points used each lift table for testing purposes in the space provided below: } \\
\text { PORT } \\
\text { TRANSMITTER SET POINT (KILOGRAMS) } \\
\text { 107-DO-07-201 }\end{array}$ & $\begin{array}{l}\text { Verify that the weight set point used } \\
\text { for testing purposes is recorded in } \\
\text { the space provided. }\end{array}$ & & & \\
\hline 32 & $\begin{array}{l}\text { Confirm that the "LLW RWM GLOVEBOX MAIN MENU" screen is displayed at OIU-12-105B. If a } \\
\text { sub-menu screen is displayed, press the "MAIN MENU" button to return to the "LLW RWM } \\
\text { GLOVEBOX MAIN MENU". }\end{array}$ & $\begin{array}{l}\text { Verify that the "LLW RWM } \\
\text { GLOVEBOX MAIN MENU". screen } \\
\text { is displayed at OIU-12-105B. }\end{array}$ & H & & - \\
\hline
\end{tabular}




\begin{tabular}{|c|c|c|c|c|c|}
\hline step & 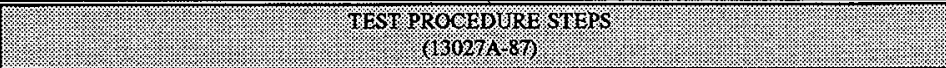 & HYPECTED OUMPUT & 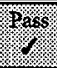 & the & Whines: \\
\hline \multicolumn{6}{|c|}{ 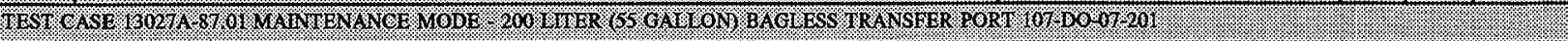 } \\
\hline 1 & $\begin{array}{l}\text { Place the } 208 \text { liter (55 gallon) Drath \& Schrader drum with inner drum lid, and without band-clam on } \\
\text { the Lift Table. Position the drum at the AGV end of the Lift Table. }\end{array}$ & $\begin{array}{l}\text { Verify that the drum is positioned on } \\
\text { the lift table at the AGV end. }\end{array}$ & & & \\
\hline 2 & $\begin{array}{l}\text { Press "FORWARD" on Control Pedestal PC-07-201F. } \\
\text { Drum should move forward until centered under the port, motor should automatically de-energize. } \\
\text { The "DRUM UNDER PORT" light on the Control Pedestal should be illuminated. }\end{array}$ & $\begin{array}{l}\text { Verify that the conveyor motor de- } \\
\text { energizes when the drum is centered } \\
\text { under the port. } \\
\text { Verify that the "DRUM UNDER } \\
\text { PORT" light is illuminated. }\end{array}$ & & & \\
\hline 3 & $\begin{array}{l}\text { Record the password for Bagless Transfer Port "Manual Mode" operation in the space provided below: } \\
\text { Password: } 88888888\end{array}$ & $\begin{array}{l}\text { Verify that the Bagless Transfer Port } \\
\text { "Manual Mode" operation is } \\
\text { recorded in the space provided. }\end{array}$ & & & \\
\hline 4 & $\begin{array}{l}\text { The Bagless Transfer Port Control Panel should be turned off at the beginning of this test procedure. } \\
\text { If the Control Panel is not turned off, place the Bagless Transfer Port in its starting position (Closed, } \\
\text { locked, double lid lowered, with no Cross lid attached) and turn the panel off using the "On/Off" } \\
\text { button. }\end{array}$ & $\begin{array}{l}\text { Verify that the Bagless Transfer Port } \\
\text { control panel is turned off. }\end{array}$ & $\checkmark$ & & \\
\hline 5 & 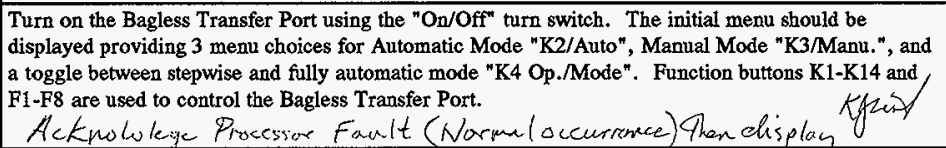 & $\begin{array}{l}\text { Verify that the Bagless Transfer Port } \\
\text { Control Panel is turned on. } \\
\text { Verify that the initial Bagless } \\
\text { Transfer Port menu is displayed. }\end{array}$ & & & \\
\hline 6 & $\begin{array}{l}\text { Press button "K30 to select "Manual Mode" } \\
\text { A message should be displayed indicating "MANUAL SERVICE - Be Careful! -". The Manual Mode } \\
\text { menu displayed should also indicate that the operator can press button "F8" to continue or press "K5" } \\
\text { to "ESC" (cancel manual mode operation). }\end{array}$ & $\begin{array}{l}\text { Verify that the message described is } \\
\text { displayed. }\end{array}$ & $\checkmark$ & & \\
\hline 7 & $\begin{array}{l}\text { Press button "F8" to use "Manual Mode". A message should briefly be displayed indicating "317 } \\
\text { Password Level Invalid" immediately followed by a "Password........." message. }\end{array}$ & $\begin{array}{l}\text { Verify that a "Password........." } \\
\text { message is displayed. }\end{array}$ & 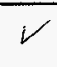 & & \\
\hline
\end{tabular}


HNF-SD-W026-ATR-021 Rev. 1

\begin{tabular}{|c|c|c|c|c|c|}
\hline Siep: & 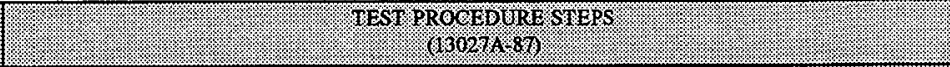 & 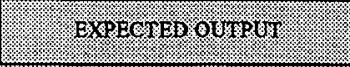 & (3ass: & (3.1. & (iningiz). \\
\hline \multicolumn{6}{|c|}{ 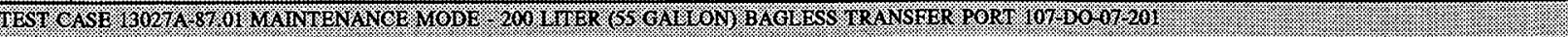 } \\
\hline 8 & $\begin{array}{l}\text { Enter the Bagless Transfer Port "Manual Mode" operation password established during setup. After } \\
\text { the password has been verified press the "Enter" button. } \\
\text { A "Password........." message should be displayed (again). }\end{array}$ & $\begin{array}{l}\text { Verify that the password has been } \\
\text { correctly entered. } \\
\text { Verify that a "Password........." } \\
\text { message is displayed. }\end{array}$ & & & \\
\hline 9 & $\begin{array}{l}\text { Press the "ESC" button to return to initial Manual Mode menu. } \\
\text { A message should be displayed indicating "MANUAL SERVICE - Be Careful! -". The manual mode } \\
\text { menu displayed should also indicate that the operator can press button "F8" to continue or press "K5" } \\
\text { to "ESC" (cancel manual mode operation). }\end{array}$ & $\begin{array}{l}\text { Verify that the message described is } \\
\text { displayed. }\end{array}$ & 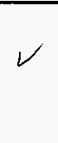 & & \\
\hline 10 & $\begin{array}{l}\text { Press the "F8" button to begin controlling the Bagless Transfer Port in manual mode. } \\
\text { A menu should be displayed, labeled "MANU: SERVICE" should be displayed. }\end{array}$ & $\begin{array}{l}\text { Verify that the menu described is } \\
\text { displayed. }\end{array}$ & L & & \\
\hline 11 & $\begin{array}{l}\text { Activate the lift table "Raise" pushbutton at the lift table local control pedestal to slowly raise the Lift } \\
\text { Table until the drum is approximately } 2.5 \text { centimeters }(1 \text { inch) below the bagless transfer port mating } \\
\text { surface. }\end{array}$ & $\begin{array}{l}\text { Verify that the lift table raises the } \\
\text { drum to within approximately } 2.5 \\
\text { centimeters ( } 1 \text { inch) of the bagless } \\
\text { transfer port. }\end{array}$ & $\gamma$ & & \\
\hline 12 & $\begin{array}{l}\text { CAUTION: Do not exceed by more than 5\% the predetermined setpoint for the conveyor weight } \\
\text { transmitter. } \\
\text { Carefully activate the lift table "Raise" pushbutton at the lift table local control pedestal to slowly raise } \\
\text { the Lift Table until the drum contacts the bagless transfer port mating surface. } \\
\text { The weight transmitter (09-WIT-231) readout should be carefully monitored to ensure that the weight } \\
\text { setpoint is not exceeded. }\end{array}$ & $\begin{array}{l}\text { Verify that the weight transmitter } \\
\text { readout is displayed. }\end{array}$ & it & & \\
\hline 13 & $\begin{array}{l}\text { Activate the lift table "Raise" pushbutton at the lift table local control pedestal to slowly raise the Lift } \\
\text { Table until the weight setpoint is reached. }\end{array}$ & $\begin{array}{l}\text { Verify that the predetermined weight } \\
\text { set point (established during setup of } \\
\text { this procedure) has been reached. }\end{array}$ & L & & \\
\hline
\end{tabular}




\begin{tabular}{|c|c|c|c|c|c|}
\hline Step o & F EST PROCEDURE S IEPS & 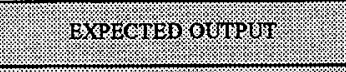 & Pass & rivit. & fials \\
\hline \multicolumn{6}{|c|}{ 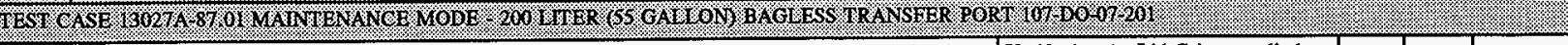 } \\
\hline 14 & $\begin{array}{l}\text { Using the Bagless Transfer Port Control Panel, press the up and down arrow buttons as needed, select } \\
\text { the "Lid Gripper Hold" option (K13) to grip the cross lid. } \\
\text { On the Bagless Transfer Port Control Panel, initially button "K13" should be illuminated and button } \\
\text { "K14" should be flashing, indicating that the Lid Gripper is not gripping the Cross Lid. After "K13" } \\
\text { has been pressed, "K14" should be illuminated and "K13" should be flashing, indicating that the Lid } \\
\text { Gripper is holding the lid. } \\
\text { The lid gripper cylinder should smoothly lower to project the gripper extensions to grip the drum lid. }\end{array}$ & $\begin{array}{l}\text { Verify that the Lid Gripper cylinder } \\
\text { smoothly lowers to extend the Lid } \\
\text { Gripper to grip the lid. } \\
\text { Verify that button "K13" is } \\
\text { illuminated before being pressed and } \\
\text { is flashing after being pressed. }\end{array}$ & & & \\
\hline 15 & $\begin{array}{l}\text { Using the up and down arrow buttons as needed, select the "Double Lid Vertical Up" option (K14) to } \\
\text { raise the Double Lid. On the Bagless Transfer Port Control Panel, initially button "K14" should be } \\
\text { illuminated and button "K13" should be flashing, indicating that the Double Lid is not raised. After } \\
\text { "K14" has been pressed, "K13" should be illuminated and "K14" should be flashing, indicating that the } \\
\text { Double Lid has been raised. } \\
\text { The three lifting cylinders should smoothly raise the Double lid to its fully raised position. }\end{array}$ & $\begin{array}{l}\text { Verify that the Double Lid cylinders } \\
\text { smoothly raise the Double Lid. } \\
\text { Verify that button "K14" is } \\
\text { illuminated before being pressed and } \\
\text { is flashing after being pressed. }\end{array}$ & & & \\
\hline 16 & $\begin{array}{l}\text { Using the up and down arrow buttons as needed, select the "Double Lid Lock Open" option (K14) to } \\
\text { unlock the Double Lid. } \\
\text { On the Bagless Transfer Port Control Panel, initially button "K14" should be illuminated and button } \\
\text { "K13" should be flashing, indicating that the Double Lid is locked. After "K14" has been pressed, } \\
\text { "K13" should be illuminated and "K14" should be flashing, indicating that the Double Lid is unlocked. } \\
\text { The Double Lid Lock Cylinder should retract to unlock the port. }\end{array}$ & $\begin{array}{l}\text { Verify that the Double Lid is } \\
\text { unlocked. } \\
\text { Verify that button "K14" is } \\
\text { illuminated before being pressed and } \\
\text { is flashing after being pressed. }\end{array}$ & 6 & & \\
\hline 17 & $\begin{array}{l}\text { Using the up and down arrow buttons as needed, select the "Double Lid System Open" option (K14) to } \\
\text { rotate the Double Lid open. } \\
\text { Press button "K14" until the port is completely rotated open and no longer rotates while button "K14" } \\
\text { is pressed. } \\
\text { On the Bagless Transfer Port Control Panel, initially button "K14" should be illuminated and button } \\
\text { "K13" should be flashing, indicating that the Double Lid is lowered. After "K14" has been pressed } \\
\text { and the Double Lid is rotated fully open, button "K14" should be flashing and button "K13" should be } \\
\text { illuminated, indicating that the port is fully rotated open. }\end{array}$ & $\begin{array}{l}\text { Verify that the Double Lid cylinder } \\
\text { smoothly raises the Double Lid. } \\
\text { Verify that the port door is } \\
\text { completely rotated open. } \\
\text { Verify that button "K14" is } \\
\text { illuminated before being pressed and } \\
\text { is flashing after being pressed. }\end{array}$ & & & \\
\hline
\end{tabular}




\begin{tabular}{|c|c|c|c|c|c|}
\hline Step & (1) & 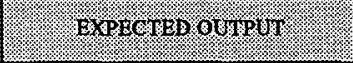 & 3\% & \% & (Mantialy \\
\hline \multicolumn{6}{|c|}{ 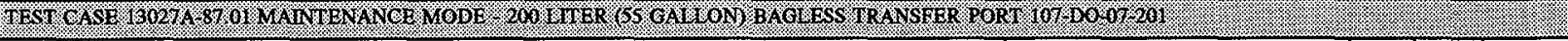 } \\
\hline 18 & $\begin{array}{l}\text { Using the up and down arrow buttons as needed, select the "Double Lid System Close" option (K13) to } \\
\text { rotate the Double Lid closed. } \\
\text { Press button "K13" until the port is completely rotated closed and no longer rotates while button "K13" } \\
\text { is pressed. } \\
\text { On the Bagless Transfer Port Control Panel, initially button "K14" should be flashing and button } \\
\text { "K13" should be illuminated, indicating that the Double Lid is raised. After "K13" has been pressed } \\
\text { and the Double Lid is rotated fully closed, button "K14" should be illuminated and button "K13" } \\
\text { should be flashing, indicating that the Double Lid is rotated closed. }\end{array}$ & $\begin{array}{l}\text { Verify that the Double Lid cylinder } \\
\text { smoothly lowers the Double Lid. } \\
\text { Verify that the port door is } \\
\text { completely rotated closed. } \\
\text { Verify that button "K13" is } \\
\text { illuminated before being pressed and } \\
\text { is flashing after being pressed. }\end{array}$ & & & \\
\hline 19 & $\begin{array}{l}\text { Using the up and down arrow buttons as needed, select the "Double Lid Lock Close" option (K13) to } \\
\text { lock the Double Lid. On the Bagless Transfer Port Control Panel, initially button "K13" should be } \\
\text { illuminated and button "K14" should be flashing, indicating that the Double Lid is unlocked. After } \\
\text { "K13" has been pressed, "K14" should be illuminated and "K13" should be flashing, indicating that the } \\
\text { Double Lid is locked. } \\
\text { The Double Lid Lock Cylinder should extend to lock the port. }\end{array}$ & $\begin{array}{l}\text { Verify that button "K13" is } \\
\text { illuminated before being pressed and } \\
\text { is flashing after being pressed. } \\
\text { Verify that the Double Lid is locked. }\end{array}$ & & & \\
\hline$\overline{20}$ & $\begin{array}{l}\text { Using the up and down arrow buttons as needed, select the "Double Lid Vertical Down" option (K13) } \\
\text { to lower the Double Lid. On the Bagless Transfer Port Control Panel, initially button "K13" should be } \\
\text { illuminated and button "K14" should be flashing, indicating that the Double Lid is not lowered. After } \\
\text { "K13" has been pressed, "K14" should be illuminated and "K13" should be flashing, indicating that the } \\
\text { Double Lid has been lowered. } \\
\text { The three lifting cylinders should smoothly lower the Double lid to its fully lowered closed position. }\end{array}$ & $\begin{array}{l}\text { Verify that button "K13" is } \\
\text { illuminated before being pressed and } \\
\text { is flashing after being pressed. } \\
\text { Verify that the Double Lid cylinders } \\
\text { smoothly lower the Double Lid. }\end{array}$ & & & \\
\hline 21 & $\begin{array}{l}\text { Using the up and down arrow buttons as needed, select the "Lid Gripper Release" option (K14) to } \\
\text { release the Cross lid. On the Bagless Transfer Port Control Partel, initially button "K14" should be } \\
\text { illuminated and button "K13" should be flashing, indicating that the Lid Gripper is gripping the Cross } \\
\text { Lid. After "K14" has been pressed, "K13" should be illuminated and "K14" should be flashing, } \\
\text { indicating that the Lid Gripper has released the lid. } \\
\text { The lid gripper cylinder should smoothly raise to release the drum lid. }\end{array}$ & $\begin{array}{l}\text { Verify that button "K14" is } \\
\text { illuminated before being pressed and } \\
\text { is flashing after being pressed. } \\
\text { COnsm VERIFY' } \\
\text { rerify that the-lid grippereytinder }\end{array}$ & & & \\
\hline
\end{tabular}


HNF-SD-W026-ATR-021 Rev. 1

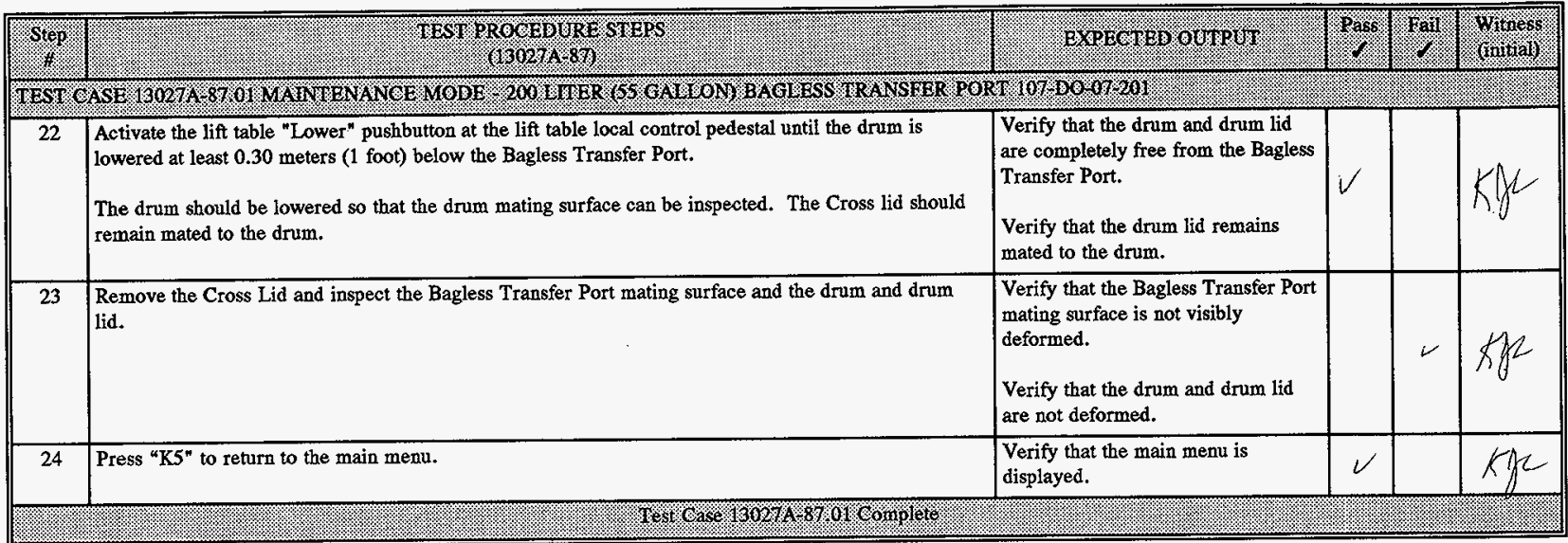




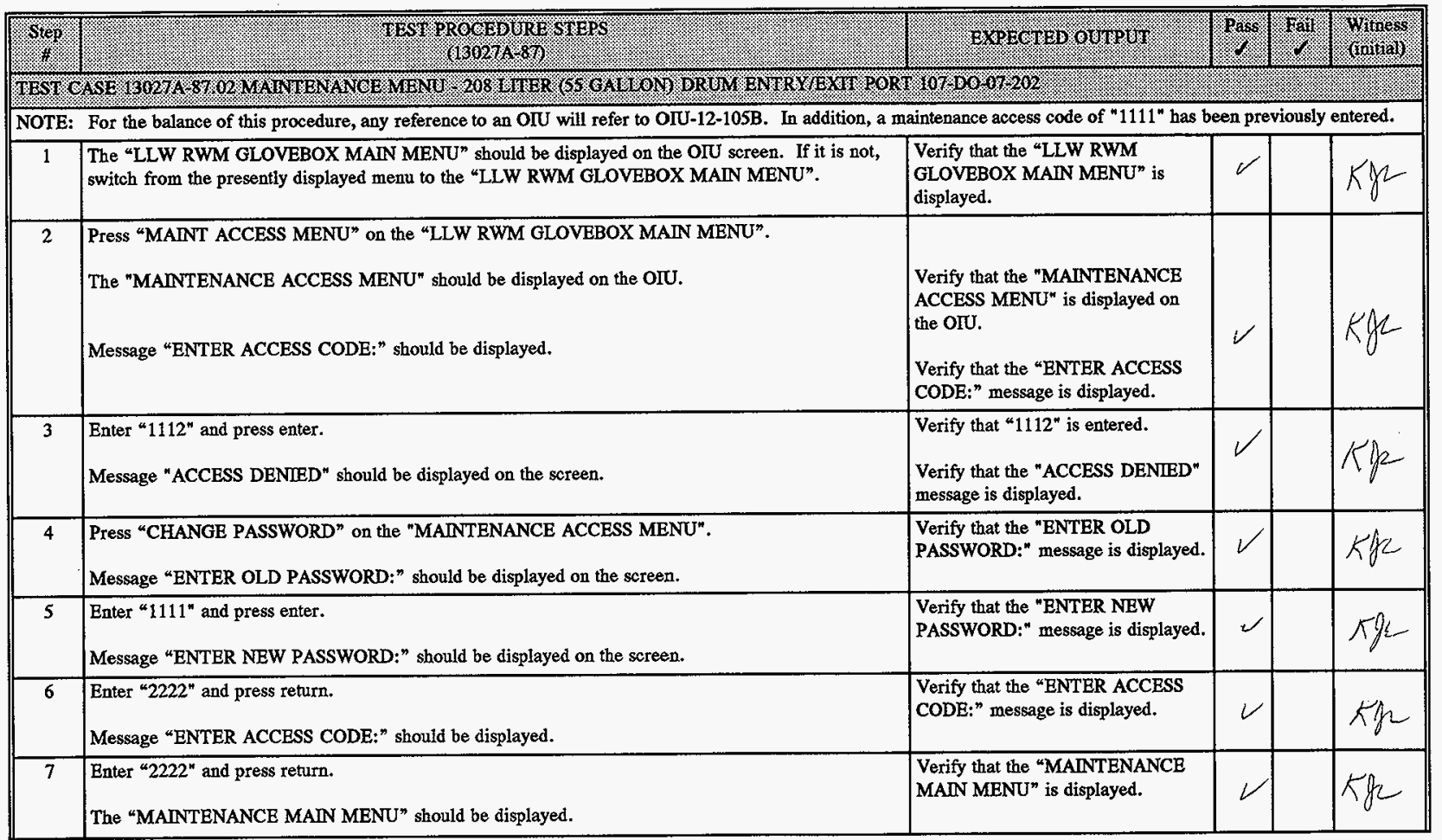




\begin{tabular}{|c|c|c|c|c|c|}
\hline Step & IUST PROCEOURF SYUPS & 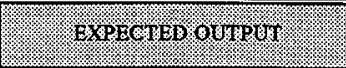 & Pas & revar. & (initial) \\
\hline \multicolumn{6}{|c|}{ 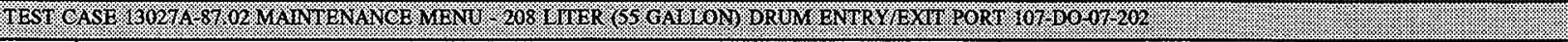 } \\
\hline 8 & $\begin{array}{l}\text { Press "PORT DO-07-202 MAINTENANCE MENU" on the "MAINTENANCE MAIN MENU". } \\
\text { The "PORT DO-07-202 MAINTENANCE MENU" should be displayed. }\end{array}$ & $\begin{array}{l}\text { Verify that "PORT DO-07-202 } \\
\text { MAINTENANCE MENU" is } \\
\text { selected. } \\
\text { Verify that the "PORT DO-07-202 } \\
\text { MAINTENANCE MENU" is } \\
\text { displayed. }\end{array}$ & $\checkmark$ & & \\
\hline 9 & Press "UNLOCK PORT" on the "PORT DO-07-202 MAINTENANCE MENU". & $\begin{array}{l}\text { Verify that both shot bolts are fully } \\
\text { retracted. }\end{array}$ & ir & & \\
\hline 10 & $\begin{array}{l}\text { Press "RAISE DOOR" on the "PORT DO-07-202 MAINTENANCE MENU". } \\
\text { Poor ad jus ted to }<1 / 2 \mathrm{in} / \mathrm{sec}\end{array}$ & Verify that the Port Door opens. & & & \\
\hline 11 & 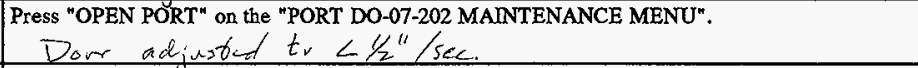 & $\begin{array}{l}\text { Verify that the Port Door rotates } \\
\text { open. }\end{array}$ & 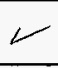 & & \\
\hline 12 & $\begin{array}{l}\text { Press "CLOSE PORT" on the "PORT DO-07-202 MAINTENANCE MENU". } \\
\text { Dowr adhis fot to }<1 / z \text { "/sce. }\end{array}$ & $\begin{array}{l}\text { Verify that the Port Door rotates } \\
\text { closed. }\end{array}$ & $r$ & & \\
\hline 13 & $\begin{array}{l}\text { Press "LOWER DeOR" on the "PORT DO-07-202 MAINTENANCE MENU". } \\
\text { Door ad iutcd Es }</ / 2 \text { " } / 5 \mathrm{es} \text {. }\end{array}$ & $\begin{array}{l}\text { Verify that the Port Door lowers } \\
\text { closed. }\end{array}$ & $\nu$ & & $\wedge$ \\
\hline 14 & Press "LOCK PORT" on the "PORT DO-07-202 MAINTENANCE MENU". & $\begin{array}{l}\text { Verify that both shot bolts are fully } \\
\text { extended. }\end{array}$ & $\mho$ & & Klyz \\
\hline 15 & Press "EXTEND LD DETACH" on the "PORT DO-07-202 MAINTENANCE MENU". & $\begin{array}{l}\text { Verify that the lid detach cylinder } \\
\text { fully extends. }\end{array}$ & $W$ & & $K H$ \\
\hline 16 & Press "RETRACT LID DETACH" on the "PORT DO-07-202 MAINTENANCE MENU". & $\begin{array}{l}\text { Verify that the lid detach cylinder } \\
\text { fully retracts. }\end{array}$ & $V$ & & $\mathrm{~kg}$ \\
\hline 17 & Press "OPEN ISOLATION VALVE" on the "PORT DO-07-202 MAINTENANCE MENU". & Verify that the vacuum supply valve & & & \\
\hline & OBSOLETE COMMAND KK hard $4 / 22 / 47$ & is open. & & & \\
\hline 18 & 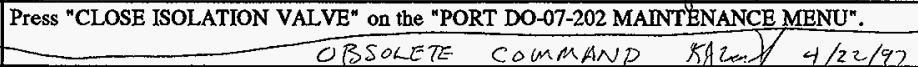 & $\begin{array}{l}\text { Verify that the vacuum supply valve- } \\
\text { is closed. }\end{array}$ & & & \\
\hline 19 & Press "TURN ON VACUUM" on the "PORT DO-07-202 MAINTENANCE MENU". & $\begin{array}{l}\text { Verify that the vacuum supply } \\
\text { system is on. }\end{array}$ & $L$ & & 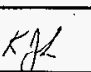 \\
\hline 20 & Press "TURN OFF VACUUM" on the "PORT DO-07-202 MAINTENANCE MENU". & $\begin{array}{l}\text { Verify that the vacuum supply } \\
\text { system is off. }\end{array}$ & $\nu$ & & $x / z$ \\
\hline
\end{tabular}


HNF-SD-W026-ATR-021 Rev. 1

\begin{tabular}{|c|c|c|c|c|c|}
\hline 89 & IEST PR OUEDURE STEPS & 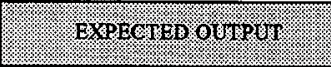 & Tras. & (2) & (onitialin) \\
\hline \multicolumn{6}{|c|}{ 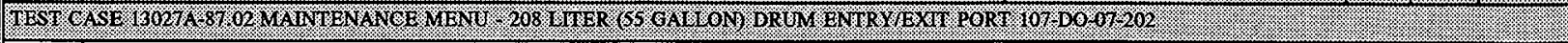 } \\
\hline 21 & $\begin{array}{l}\text { Press "MAINT MAIN MENU" on the "PORT DO-07-202 MAINTENANCE MENU". } \\
\text { The "MAINTENANCE MAIN MENU" should be displayed on the screen. }\end{array}$ & $\begin{array}{l}\text { Verify that the "MAINTENANCE } \\
\text { MAIN MENU" is displayed. }\end{array}$ & $r$ & & \\
\hline & Tes & & & & \\
\hline
\end{tabular}




\begin{tabular}{|c|c|c|c|c|c|}
\hline Step & WESTRONLWRE STETS & 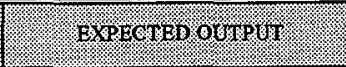 & 1/2s. & Fin: & Wininess \\
\hline \multicolumn{6}{|c|}{ 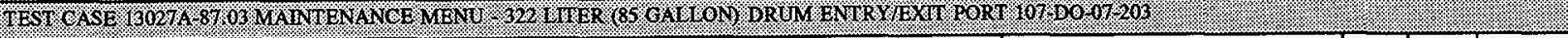 } \\
\hline 1 & $\begin{array}{l}\text { Press "PORT D0-07-203 MAINTENANCE MENU" on the "MAINTENANCE MANN MENU". } \\
\text { The "PORT DO-07-203 MAINTENANCE MENU" should be displayed. }\end{array}$ & $\begin{array}{l}\text { Verify that "PORT DO-07-203 } \\
\text { MAINTENANCE MENU" is } \\
\text { selected. } \\
\text { Verify that the "PORT DO-07-203 } \\
\text { MAINTENANCE MENU" is } \\
\text { displayed. }\end{array}$ & $\checkmark$ & & \\
\hline 2 & Press "UNLOCK PORT" on the "PORT DO-07-203 MAINTENANCE MENU". & $\begin{array}{l}\text { Verify that both shot bolts are fully } \\
\text { retracted. }\end{array}$ & $V$ & & \\
\hline 3 & Press "RAISE DOOR" on the "PORT DO-07-203 MAINTENANCE MENU". & Verify that the Port Door opens. & 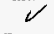 & & $k j 2$ \\
\hline 4 & $\begin{array}{l}\text { Press "OPEN PORT" on the "PORT DO-07-203 MAINTENANCE MENU". } \\
\text { Adqust tot to }</ 2 " / \mathrm{sec} \text {. }\end{array}$ & $\begin{array}{l}\text { Verify that the Port Door rotates } \\
\text { open. }\end{array}$ & $\checkmark$ & & \\
\hline 5 & $\begin{array}{l}\text { Press "CLOSE PORT" on the "PORT DO-07-203 MAINTENANCE MENU". } \\
\text { Ad jus the } t t_{0}<1 / 2 " 1 / \mathrm{sec} \text {. }\end{array}$ & $\begin{array}{l}\text { Verify that the Port Door rotates } \\
\text { closed. }\end{array}$ & $\checkmark$ & & \\
\hline 6 & $\begin{array}{l}\text { Press "LOWER DOOR" on the "PORT DO-07-203 MAINTENANCE MENU". } \\
\text { Af diusted to }</ / 2 \text { " } / \mathrm{sec} \text {. }\end{array}$ & $\begin{array}{l}\text { Verify that the Port Door lowers } \\
\text { closed. }\end{array}$ & $\checkmark$ & & \\
\hline 7 & Press "LOCK PORT" on the "PORT DO-07-203 MAINTENANCE MENU". & $\begin{array}{l}\text { Verify that both shot boits are fully } \\
\text { extended. }\end{array}$ & $\forall$ & & \\
\hline 8 & $\begin{array}{l}\text { Press "EXTEND LID DETACH" on the "PORT DO-07-203 MAINTENANCE MENU". } \\
\text { A lí us } 2 \text { to slow extende }\end{array}$ & $\begin{array}{l}\text { Verify that the lid detach cylinder } \\
\text { fully extends. }\end{array}$ & $\checkmark$ & & 2 \\
\hline 9 & Press "RETRACT LID DETACH" on the "PORT DO-07-203 MANNTENANCE MENU". & $\begin{array}{l}\text { Verify that the lid detach cylinder } \\
\text { fully retracts. }\end{array}$ & $\checkmark$ & & $k / 2$ \\
\hline 10 & $\begin{array}{l}\text { Press "OPEN TSOLATTON VALVE" on the "PORT DOO-07-203 MADNTENANCEMENU". } \\
\text { OBEOKETE COMMAND KN UDAN" }\end{array}$ & $\begin{array}{l}\text { Verify that the vacuum supply valve } \\
\text { is open. }\end{array}$ & & & \\
\hline 11 & 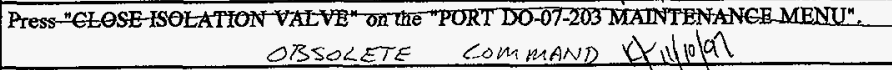 & $\begin{array}{l}\text { Verify that the vacuum supply valve } \\
\text { is closed. }\end{array}$ & & & \\
\hline 12 & Press "TURN ON VACUUM" on the "PORT DO-07-203 MAINTENANCE MENU". & $\begin{array}{l}\text { Verify that the vacuum supply } \\
\text { system is on. }\end{array}$ & $\dot{V}$ & & $K_{j}$ \\
\hline 13 & Press "TURN OFF VACUUM" on the "PORT DO-07-203 MAINTENANCE MENU". & $\begin{array}{l}\text { Verify that the vacuum supply } \\
\text { system is off. }\end{array}$ & $V$ & & $5 \mathrm{gl}$ \\
\hline
\end{tabular}


离

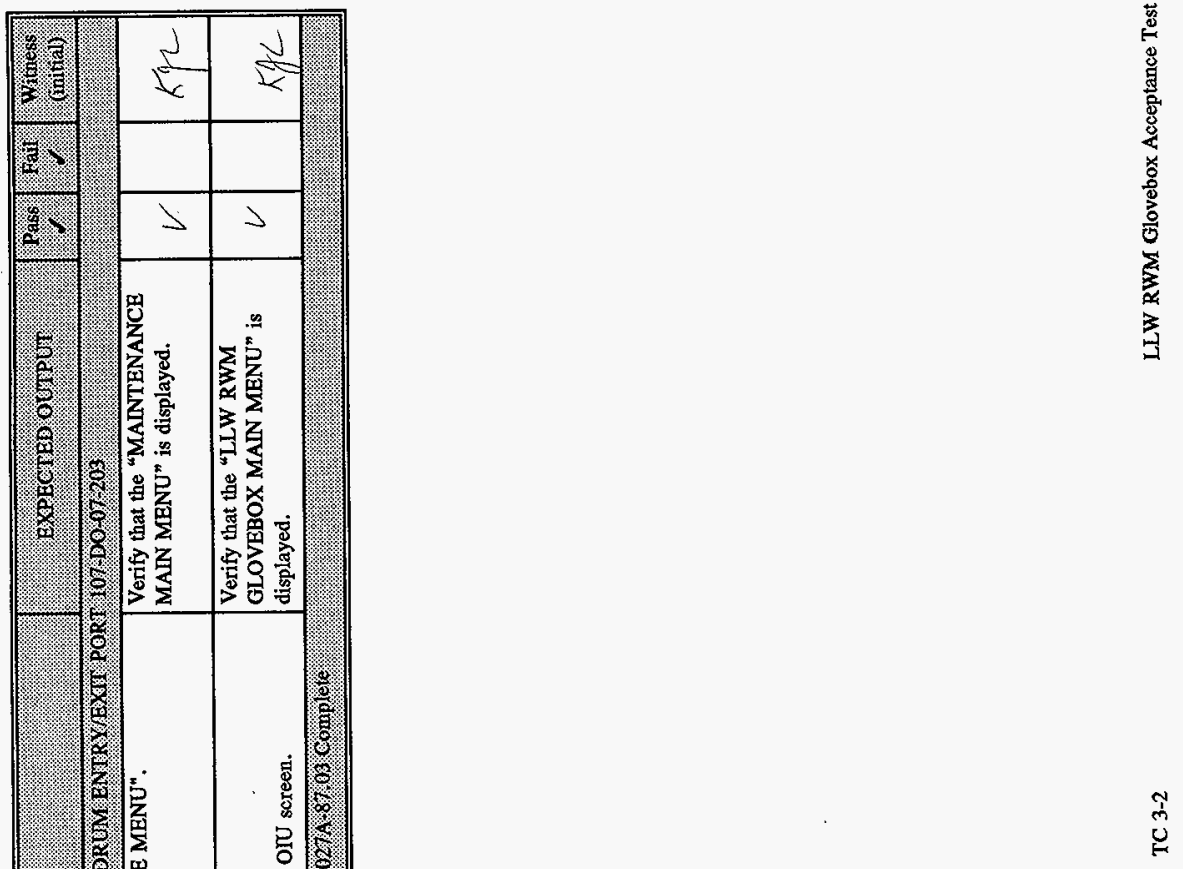


HNF-SD-W026-ATR-021 Rev. 1

\begin{tabular}{|c|c|c|c|c|c|}
\hline Sto & 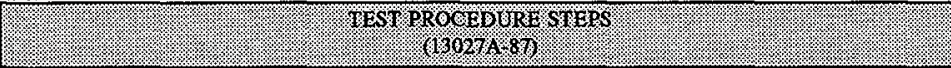 & EXPECTEO OH \% & 㩁 & (1) & (initiai) \\
\hline \multicolumn{6}{|c|}{ 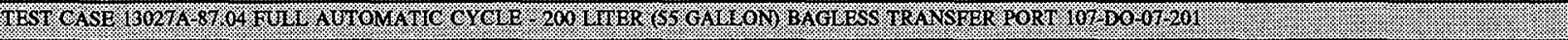 } \\
\hline 1 & $\begin{array}{l}\text { The "LLW RWM GLOVEBOX MAIN MENU" should be displayed on the OIU screen. If it is not, } \\
\text { switch from the presently displayed menu to the "LLW RWM GLOVEBOX MAIN MENU". }\end{array}$ & $\begin{array}{l}\text { Verify that the "LLW RWM } \\
\text { GLOVEBOX MAIN MENU" is } \\
\text { displayed. }\end{array}$ & L & & \\
\hline 2 & $\begin{array}{l}\text { Press "PORT D0-07-201 MENU" on the "LLW RWM GLOVEBOX MAIN MENU". } \\
\text { The "PORT D0-07-201 MENU" should be displayed. }\end{array}$ & $\begin{array}{l}\text { Verify that the "PORT DO-07-201 } \\
\text { MENU" is displayed. }\end{array}$ & V & & \\
\hline 3 & $\begin{array}{l}\text { The Bagless Transfer port control console is still in manual mode. Press "K2" to select Automatic } \\
\text { Mode. }\end{array}$ & $\begin{array}{l}\text { Verify that the Bagless Transfer port } \\
\text { control console is in the Full } \\
\text { Automatic Mode. }\end{array}$ & V & & \\
\hline 4 & $\begin{array}{l}\text { Visually inspect the Glovebox area. Confirm that the bagless transfer port that will be tested and all } \\
\text { items associated with this glovebox are ready for operation and that no debris or other foreign matter is } \\
\text { present that would disrupt testing. }\end{array}$ & $\begin{array}{l}\text { Verify that the bagless transfer port } \\
\text { has been prepared for operation and } \\
\text { testing. }\end{array}$ & $\zeta$ & & \\
\hline 5 & $\begin{array}{l}\text { Prepare one empty } 208 \text { liter ( } 55 \text { gallon) Drath and Schrader drum with Cross Lid. This type of drum } \\
\text { is designed to function with the Bagless Transfer Port. }\end{array}$ & $\begin{array}{l}\text { Verify that a Drath and Schrader } \\
\text { drum with lid is available for testing. }\end{array}$ & & & \\
\hline 6 & $\begin{array}{l}\text { The Bagless Transfer Port requires that the port load cell indicate that predetermined weight set point } \\
\text { has been reached before the port is enabled for operation. } \\
\text { Record the weight set point indicated on the OIU screen used for testing purposes in the space } \\
\text { provided below: }(650-700 \text { kilograms) } \\
\text { Bagless Transfer Port Weight Set Point: } 650 \quad \mathrm{~kg}(\mathrm{w} \% \text { Drum iver (X) }\end{array}$ & $\begin{array}{l}\text { Verify that the weight set point used } \\
\text { for testing purposes is shown in the } \\
\text { space provided to the left. }\end{array}$ & $v$ & & \\
\hline 7 & At control pedestal PC-07-201F place "M/O/N" switch to "NORMAL". & $\begin{array}{l}\text { Verify that "M/O/N" switch is set to } \\
\text { "NORMAL". }\end{array}$ & Q & & \\
\hline
\end{tabular}




\begin{tabular}{|c|c|c|c|c|c|}
\hline Step & TEST PROCEDURE STERS & 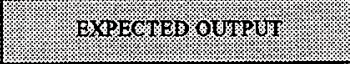 & Ifass. & (8). & Yitress: \\
\hline \multicolumn{6}{|c|}{ 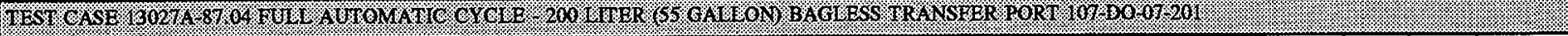 } \\
\hline 8 & 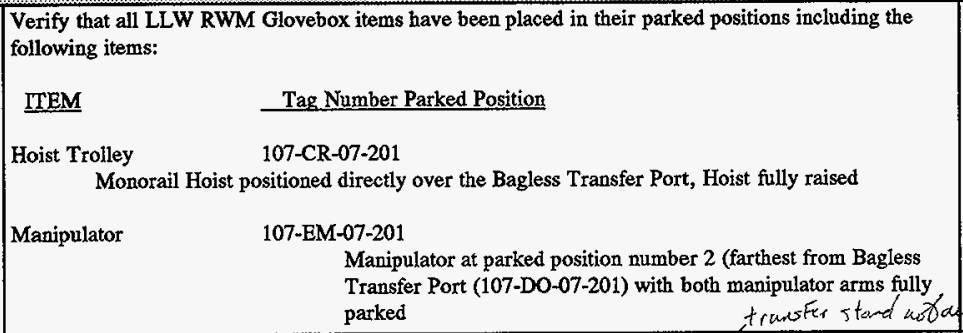 & $\begin{array}{l}\text { Verify that all glovebox items } \\
\text { present have been placed in their } \\
\text { parked positions. }\end{array}$ & $\checkmark$ & & \\
\hline$\overline{9}$ & $\begin{array}{l}\text { Place a } 208 \text { liter (55 gallon) Drath \& Schrader drum with inner drum lid, transfer-stand;-and outer lid } \\
\text { at the AGV end of lift table 107-LT-09-201F such that the drum interrupts the light beam of } \\
\text { photosensor ZS-231F. } \\
\text { The "AGV END" light on the Control Pedestal should be ithrminated. Not illamirsfod K/findf } \\
\text { Message "NO DRUM AT LIFT TABLE" should be displayed on the OIU screen. }\end{array}$ & $\begin{array}{l}\text { Verify that the drum is interrupting } \\
\text { the light beam of the photosensor. } \\
\text { Verify that the "AGV END" light is, } \\
\text { illuminated. } \\
\text { Verify that the "NO DRUM AT } \\
\text { LIFT TABLE" message is displayed. }\end{array}$ & & & \\
\hline 10 & Remove the-outer-lid-from the-drum. OBSOLETE COMMAND-OUTER LIDS NOT USED & Verify that the-outer tid is Temoved.- & & & \\
\hline 11 & $\begin{array}{l}\text { Move the drom toward the port far enought so the photosensor light beam has been reestablished. } \\
\text { FORCED STATUS } B / T \quad N 3 /=106 / \mathrm{R} \\
\text { Message "DRUM AT LIFT TABLE" should be displayed on the orU screen. }\end{array}$ & $\begin{array}{l}\text { Verify that the drum is no longer } \\
\text { interrupting the light beam of the } \\
\text { photosensor. } \\
\text { Verify that the "DRUM AT LIFT } \\
\text { TABLE" message is displayed. }\end{array}$ & i & & \\
\hline 12 & $\begin{array}{l}\text { The "AGV/PANEL" switch on lift table Local Control Pedestal PC-07-201F should be in the } \\
\text { "PANEL" position. If it is in the "AGV" position, place the switch in the "PANEL" position. }\end{array}$ & $\begin{array}{l}\text { Verify that the switch is in the } \\
\text { "PANEL" position. }\end{array}$ & $\checkmark$ & & \\
\hline
\end{tabular}


HNF-SD-W026-ATR-021 Rev. 1

\begin{tabular}{|c|c|c|c|c|c|}
\hline Step & 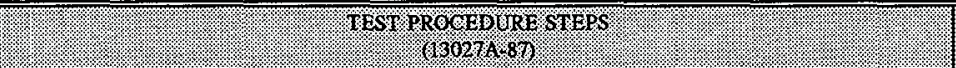 & 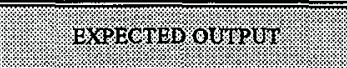 & da. & Wal & Wifiness \\
\hline \multicolumn{6}{|c|}{ 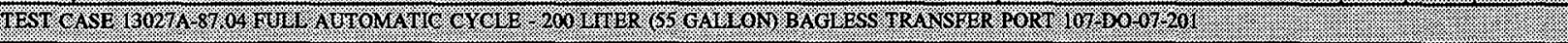 } \\
\hline 13 & $\begin{array}{l}\text { Press "FORWARD" on Control Pedestal PC-07-201F. } \\
\text { Drum should move forward until centered under the port, motor should automatically de-energize. } \\
\text { The "DRUM UNDER PORT" light on the Control Pedestal should be illuminated. }\end{array}$ & $\begin{array}{l}\text { Verify that the conveyor motor de- } \\
\text { energizes when the drum is centered } \\
\text { under the port. } \\
\text { Verify that the "DRUM UNDER } \\
\text { PORT" light is illuminated. }\end{array}$ & $V$ & & \\
\hline 14 & $\begin{array}{l}\text { Press "RAISE" on Control Pedestal PC-07-201E. } \\
\text { The drum should raise to until the predetermined weight setpoint has been reached and then stop. } \\
\text { The "DRUM IN POSITION" light on the Control Pedestal should be illuminated, indicating that the } \\
\text { predetermined weight setpoint has been reached. } \\
\text { At the OrU, the Lift Table Weight indication should be } \pm 50 \mathrm{~kg} \text { of the setpoint. } \\
\text { Record indicated Lift Table Weight: } 668 \mathrm{~kg} \text {. se } 4 \mathrm{fted} \text {. tu } 657 \mathrm{Kg} \text {. } \\
\text { Record Weight Setpoint: }\end{array}$ & $\begin{array}{l}\text { Verify that the drum raises and then } \\
\text { stops at the weight setpoint. } \\
\text { Verify that the "DRUM IN } \\
\text { POSITION" light is illuminated. } \\
\text { Verify that the Lift Table Weight } \\
\text { indication and setpoint are recorded. }\end{array}$ & $\nearrow$ & & \\
\hline 15 & 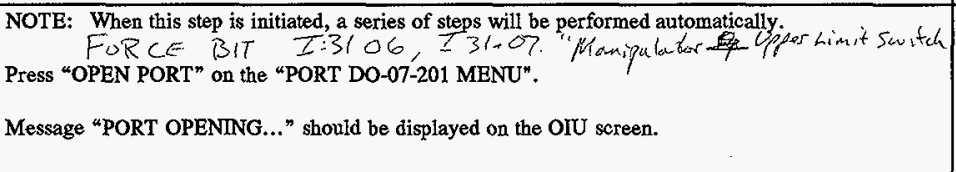 & $\begin{array}{l}\text { Verify that the "PORT } \\
\text { OPENING..." message is displayed. }\end{array}$ & & & \\
\hline 16 & $\begin{array}{l}\text { The port should raise, unlock and rotate fully open. } \\
\text { The drum lid should be attached to the port door. } \\
\text { Message "PORT OPEN" should be displayed on the OIU screen. } \\
\text { LIFT TABLE WEIGLT DROPPED TO LUI KS }\end{array}$ & $\begin{array}{l}\text { Verify that the port raises, unlocks } \\
\text { and rotates fully open. } \\
\text { Verify that the drum lid is attached } \\
\text { to the port door. } \\
\text { Verify that the "PORT OPEN" } \\
\text { message is displayed. }\end{array}$ & $v$ & & \\
\hline
\end{tabular}


HNF-SD-W026-ATR-021 Rev. 1

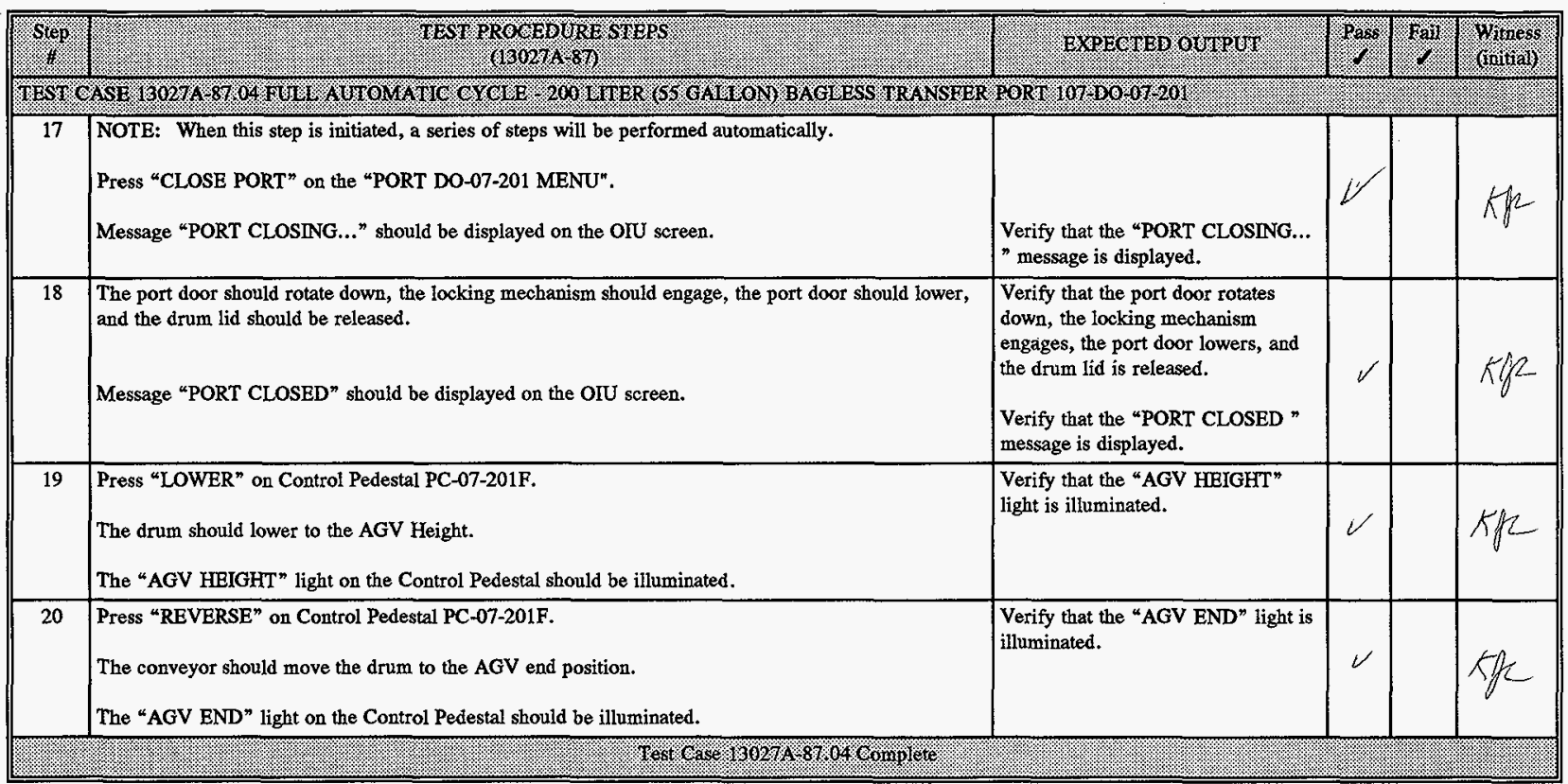




\begin{tabular}{|c|c|c|c|c|c|}
\hline Siep & 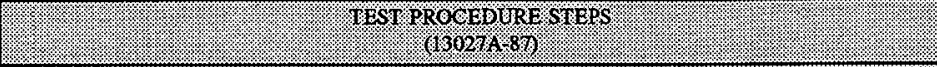 & 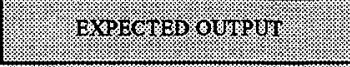 & Pass & S.1. & onitivilis \\
\hline \multicolumn{6}{|c|}{ 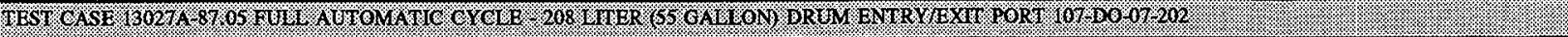 } \\
\hline 1 & $\begin{array}{l}\text { The "LLW RWM GLOVEBOX MAIN MENU" should be displayed on the OIU screen. If it is not, } \\
\text { switch from the presently displayed menu to the "LLW RWM GLOVEBOX MAIN MENU". Select } \\
\text { "Port DO-07-202 MENU". }\end{array}$ & $\begin{array}{l}\text { Verify that the "ILW-RWM- } \\
\text { GLOVEBOXXMAIN-MENU"-is } \\
\text { displayed. DO-07.202 MENU }\end{array}$ & $\checkmark$ & & \\
\hline 2 & $\begin{array}{l}\text { Place a } 208 \text { liter ( } 55 \text { gallon) drum at the AGV end of lift table 107-LT-09-201E such that the drum } \\
\text { interrupts the light beam of photosensor ZS-229E. } \\
\text { Adjust Lift Table to AGV height. } \\
\text { The "AGV END" light on the Control Pedestal should be illuminated } \\
\text { Message "NO DRUM AT LIFT TABLE" should be displayed on the OIU screen. }\end{array}$ & $\begin{array}{l}\text { Verify that the drum is interrepting } \\
\text { the light beam of the photosensor. } \\
\text { Verify that the "AGV END" light is } \\
\text { illuminated. } \\
\text { Verify that the "NO DRUM AT } \\
\text { LIFT TABLE" message is displayed. }\end{array}$ & $V$ & & \\
\hline 3 & $\begin{array}{l}\text { Move the drum toward the port far enough so the photosensor light beam has been reestablished. } \\
\text { FORCE BIT. N } 31: 94 . / 2 \\
\text { Set AGV Status Bit "ON". } \\
\text { Message "DRUM AT LIFT TABLE" should be displayed on the OIU screen. }\end{array}$ & $\begin{array}{l}\text { Verify that the drum is no longer } \\
\text { interrupting the light beam of the } \\
\text { photosensor. } \\
\text { Verify that the "DRUM AT LIFT } \\
\text { TABLE" message is displayed. }\end{array}$ & $\checkmark$ & & \\
\hline 4 & Remove the-elamp band from the drum. N/A KWN/(0) & $\begin{array}{l}\text {-Verify-that the clamp band is } \\
\text { removed. } \\
T L T\end{array}$ & $v$ & & \\
\hline 5 & $\begin{array}{l}\text { The "AGV/PANEL" switch on lift table Local Control Pedestal PC-07-201E should be in the } \\
\text { "PANEL" position. If it is in the "AGV" position, place the switch in the "PANEL" position. }\end{array}$ & $\begin{array}{l}\text { Verify that the switch is in the } \\
\text { "PANEL" position. }\end{array}$ & $\forall$ & & \\
\hline 6 & $\begin{array}{l}\text { Press "FORWARD" on Control Pedestal PC-07-201E. } \\
\text { Drum should move forward until centered under the port, motor should automatically de-energize. } \\
\text { The "DRUM UNDER PORT" light on the Control Pedestal should be illuminated. }\end{array}$ & $\begin{array}{l}\text { Verify that the conveyor motor de- } \\
\text { energizes when the drum is centered } \\
\text { under the port. } \\
\text { Verify that the "DRUM UNDER } \\
\text { PORT" light is illuminated. }\end{array}$ & $V$ & & \\
\hline 7 & $\begin{array}{l}\text { Press "RAISE" on Control Pedestal PC-07-201E. } \\
\text { The drum should raise to the Drum Centering Height. The "DRUM IN POSITION" light on the } \\
\text { Control Pedestal should be illuminated. }\end{array}$ & $\begin{array}{l}\text { Verify that the "DRUM IN } \\
\text { POSITION" light is illuminated. }\end{array}$ & $v$ & & \\
\hline
\end{tabular}


HNF-SD-W026-ATR-021 Rev. 1

\begin{tabular}{|c|c|c|c|c|c|}
\hline siep & 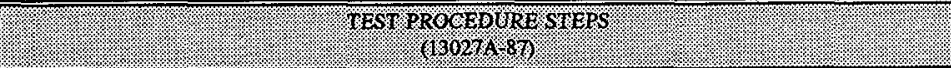 & ExprafgDourasu & 18 & (2) & (initing) \\
\hline \multicolumn{6}{|c|}{ 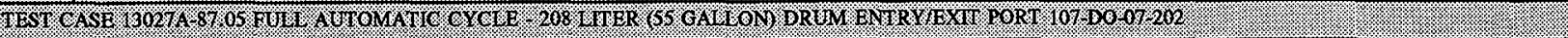 } \\
\hline 8 & $\begin{array}{l}\text { NOTE: When this step is initiated, a series of steps will be performed automatically. } \\
\text { Press "OPEN PORT" on the "PORT DO-07-202 MENU". } \\
\text { Message "PORT OPENING..." should be displayed on the OIU screen. }\end{array}$ & $\begin{array}{l}\text { Verify that the "PORT } \\
\text { OPENING..." message is displayed. }\end{array}$ & $\checkmark$ & & \\
\hline 9 & The drum centering clamps should extend to center the drum. & $\begin{array}{l}\text { Verify that the drum centering } \\
\text { clamps extend to center the drum. }\end{array}$ & $\checkmark$ & & \\
\hline 10 & The vacuum system should be activated by the PCS. & $\begin{array}{l}\text { Verify that the vacuum system is } \\
\text { activated. }\end{array}$ & $\checkmark$ & & \\
\hline 11 & The HVAC seal should inflate. & $\begin{array}{l}\text { Verify that the HVAC seal is } \\
\text { inflated. }\end{array}$ & $\checkmark$ & & \\
\hline 12 & $\begin{array}{l}\text { The PCS should energize vent valves FEV-913C\&D, thereby releasing pressure on the door open/close } \\
\text { cylinders. }\end{array}$ & $\begin{array}{l}\text { Verify that vent valves FEV- } \\
\text { 913C\&D are energized. }\end{array}$ & $\checkmark$ & & \\
\hline 13 & The port door locking bolts should both retract. & Verify that both locking bolts retract. & $\nabla$ & & \\
\hline 14 & The lift table servo motor should raise the drum to the Door in Position height and then stop. & $\begin{array}{l}\text { Verify that the door is raised to the } \\
\text { Door in Position height and then } \\
\text { stops. }\end{array}$ & $\checkmark$ & & \\
\hline 15 & $\begin{array}{l}\text { The port door open cylinders should raise the port door to the open position. } \\
\text { The drum lid should remain attached to the port door. }\end{array}$ & $\begin{array}{l}\text { Verify that the port door raises to the } \\
\text { open position. } \\
\text { Verify that the drum lid remains } \\
\text { attached to the port door. }\end{array}$ & $\checkmark$ & & \\
\hline 16 & $\begin{array}{l}\text { The port door should rotate fully open. } \\
\text { Message "PORT OPEN" should be displayed on the OIU screen. }\end{array}$ & $\begin{array}{l}\text { Verify that the port is rotated fully } \\
\text { open. } \\
\text { Verify that the "PORT OPEN" } \\
\text { message is displayed. }\end{array}$ & $\checkmark$ & & \\
\hline 17 & $\begin{array}{l}\text { NOTE: When this step is initiated, a series of steps will be performed automatically. } \\
\text { Press "CLOSE PORT" on the "PORT DO-07-202 MENU". } \\
\text { Message "PORT CLOSING..." should be displayed on the OIU screen. }\end{array}$ & $\begin{array}{l}\text { Verify that the "PORT } \\
\text { CLOSNGG..." message is displayed. }\end{array}$ & $\mathscr{V}$ & & $K h$ \\
\hline
\end{tabular}


HNF-SD-W026-ATR-021 Rev. 1

\begin{tabular}{|c|c|c|c|c|c|}
\hline Siep: & TEST PROCEDURE S TIEST & 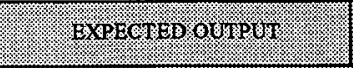 & Sis: & (4) & Tinitivili) \\
\hline \multicolumn{6}{|c|}{ 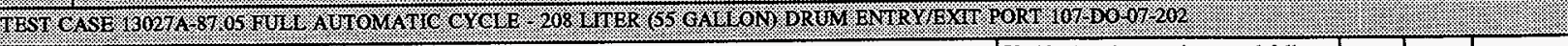 } \\
\hline 18 & The port door should rotate fully closed. & $\begin{array}{l}\text { Verify that the port is rotated fully } \\
\text { closed. }\end{array}$ & $\checkmark$ & & \\
\hline 19 & The port door open cylinders should lower the port door to the Door in Position height. & $\begin{array}{l}\text { Verify that the port door lowers to } \\
\text { the Door in Position height. }\end{array}$ & $r$ & & \\
\hline 20 & Vacuum on the drum lid should be released by the PCS. & $\begin{array}{l}\text { Verify that the vacuum is released } \\
\text { from the drum lid. }\end{array}$ & $\checkmark$ & & \\
\hline 21 & The drum lid detachment cylinder should be extended by the PCS. & $\begin{array}{l}\text { Verify that the drum lid detachment } \\
\text { cylinder is extended. }\end{array}$ & $\checkmark$ & & \\
\hline 22 & $\begin{array}{l}\text { The lift table should lower to the Drum Centering height by the PCS. } \\
\text { The port door should be fully lowered to the closed position. }\end{array}$ & $\begin{array}{l}\text { Verify that the lift table is lowered to } \\
\text { the Drum Centering height. } \\
\text { Verify that the port door is fully } \\
\text { closed. }\end{array}$ & $\checkmark$ & & \\
\hline 23 & The port door locking cylinders should fully extend to lock the port. & $\begin{array}{l}\text { Verify that the port door locking } \\
\text { cylinders are fully extended. }\end{array}$ & 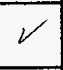 & & $K \gamma^{2}$ \\
\hline 24 & The drum lid detachment cylinder should be retracted by the PCS. & $\begin{array}{l}\text { Verify that the drum lid detachment } \\
\text { cylinder is retracted. }\end{array}$ & $\checkmark$ & & \\
\hline 25 & $\begin{array}{l}\text { The drum centering clamps should fully retract. } \\
\text { The HVAC seal should fully deflate. } \\
\text { Message "PORT CLOSED" should be displayed on the OIU screen. }\end{array}$ & $\begin{array}{l}\text { Verify that the drum centering } \\
\text { clamps fully retract. } \\
\text { Verify that the HVAC seal is fully } \\
\text { deflated. } \\
\text { Verify that the "PORT CLOSED" } \\
\text { message is displayed. }\end{array}$ & $\checkmark$ & & \\
\hline 26 & $\begin{array}{l}\text { Press "LOWER" on Control Pedestal PC-07-201E. } \\
\text { The drum should lower to the AGV Height. } \\
\text { The "AGV HEIGHT" light on the Control Pedestal should be illuminated. }\end{array}$ & $\begin{array}{l}\text { Verify that the "AGV HEIGHT" } \\
\text { light is illuminated. }\end{array}$ & $\checkmark$ & & \\
\hline
\end{tabular}




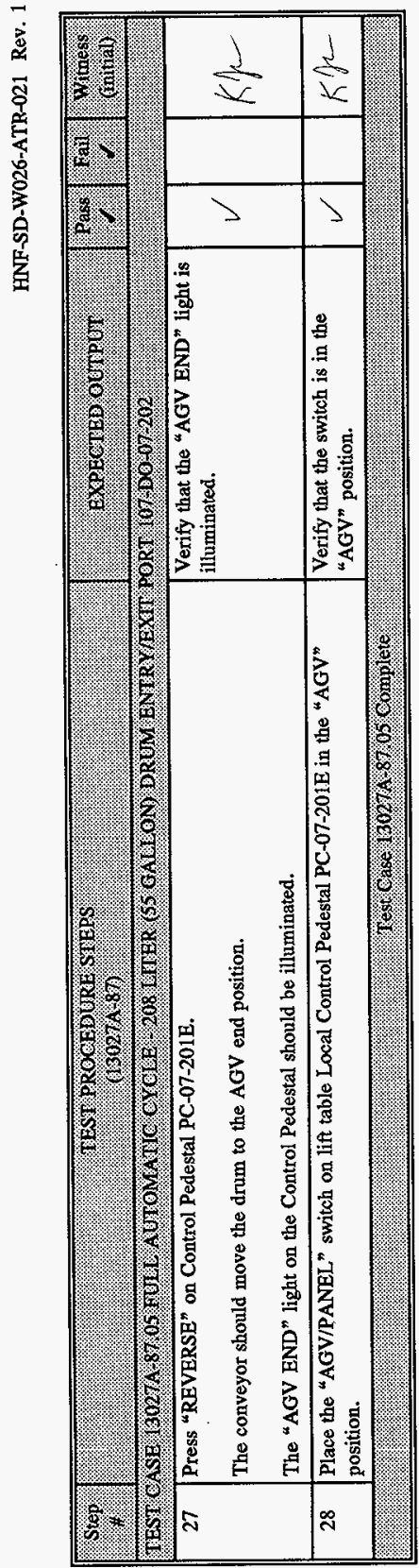

范 


\begin{tabular}{|c|c|c|c|c|c|}
\hline siep & TEST PROGEWURE STIES : $:$ : & Exprectersouryor & Pas. & (5) & \\
\hline & 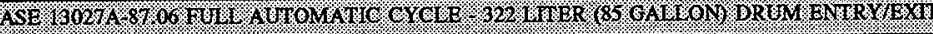 & 19010 & & & \\
\hline 1 & $\begin{array}{l}\text { The "LLW RWM GLOVEBOX MAIN MENU" should be displayed on the OIU screen. If it is not, } \\
\text { switch from the presently displayed menu to the "LLW RWM GLOVEBOX MAIN MENU". Select } \\
\text { "Port DO-07-203 MENU". }\end{array}$ & 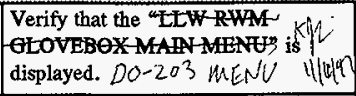 & & & \\
\hline 2 & $\begin{array}{l}\text { Place a } 322 \text { liter ( } 85 \text { gallon) drum at the AGV end of lift table 107-LT-09-201D such that the drum } \\
\text { interrupts the light beam of photosensor ZS-229E. } \\
\text { The "AGV END" light on the Control Pedestal should be illuminated } \\
\text { Message "NO DRUM AT LIFT TABLE" should be displayed on the OIU screen. }\end{array}$ & $\begin{array}{l}\text { Verify that the drum is interrupting } \\
\text { the light beam of the photosensor. } \\
\text { Verify that the "AGV END" light is } \\
\text { illuminated. } \\
\text { Verify that the "NO DRUM AT } \\
\text { LIFT TABLE" message is displayed. }\end{array}$ & & & \\
\hline 3 & $\begin{array}{l}\text { Move the drum toward the port far enough so the photosensor light beam has been reestablished. } \\
\text { ForCE BIT: N:SI- } 8 \mathrm{Z} \cdot 12 \\
\text { Set AGV Status Bit "ON". } \\
\text { Message "DRUM AT LIFT TABLE" should be displayed on the OIU screen. }\end{array}$ & $\begin{array}{l}\text { Verify that the drum is no longer } \\
\text { interrupting the light beam of the } \\
\text { photosensor. } \\
\text { Verify that the "DRUM AT LIFT } \\
\text { TABLE" message is displayed. }\end{array}$ & & & \\
\hline 4 & 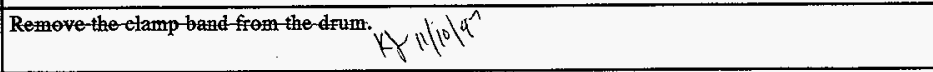 & $\begin{array}{l}\text { Verify that the clamp band is } \\
\text { removed. }\end{array}$ & $V$ & & - \\
\hline 5 & $\begin{array}{l}\text { The "AGV/PANEL" switch on lift table Local Control Pedestal PC-07-201D stould be in the } \\
\text { "PANEL" position. If it is in the "AGV" position, place the switch in the "PANEL" position. }\end{array}$ & $\begin{array}{l}\text { Verify that the switch is in the } \\
\text { "PANEL" position. }\end{array}$ & $V$ & & \\
\hline 6 & 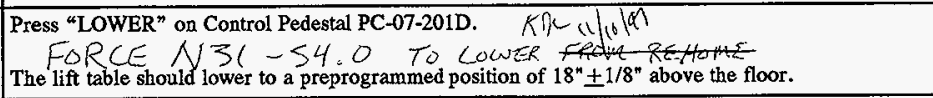 & $\begin{array}{l}\text { Verify that the lift table lowers to the } \\
\text { preprogrammed position. }\end{array}$ & st & & \\
\hline 7 & $\begin{array}{l}\text { Press "FORWARD" on Control Pedestal PC-07-201D. } \\
\text { Drum should move forward until centered under the port, motor should automatically de-energize. } \\
\text { The "DRUM UNDER PORT" light on the Control Pedestal should be illuminated. }\end{array}$ & $\begin{array}{l}\text { Verify that the conveyor motor de- } \\
\text { energizes when the drum is centered } \\
\text { under the port. } \\
\text { Verify that the "DRUM UNDER } \\
\text { PORT" light is illuminated. }^{\text {" }}\end{array}$ & $V$ & & - \\
\hline
\end{tabular}


HNF-SD-W026-ATR-021 Rev. 1

\begin{tabular}{|c|c|c|c|c|c|}
\hline Step & $\begin{array}{l}\text { REST PRQGEDURE STEPS } \\
\text { (1) }\end{array}$ & 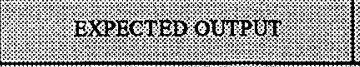 & Pass: & s. & Wines: \\
\hline \multicolumn{6}{|c|}{ 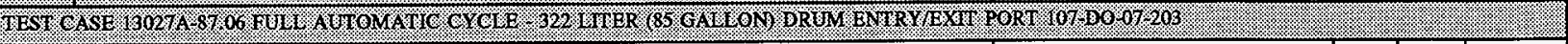 } \\
\hline 8 & $\begin{array}{l}\text { Press "RAISE" on Control Pedestal PC-07-201D. } \\
\text { The drum should raise to the Drum Centering Height. The "DRUM IN POSITION" light on the } \\
\text { Control Pedestal should be illuminated. }\end{array}$ & $\begin{array}{l}\text { Verify that the "DRUM IN } \\
\text { POSITION" light is illuminated. }\end{array}$ & $V$ & & \\
\hline 9 & $\begin{array}{l}\text { Press "PORT DO-07-203 MENU" on the "LLW RWM GLOVEBOX MAIN MENU". } \\
\text { The "PORT DO-07-203 MENU" should be displayed. }\end{array}$ & $\begin{array}{l}\text { Verify that the "PORT DO-07-203 } \\
\text { MENU" is displayed. }\end{array}$ & $r$ & & \\
\hline 10 & $\begin{array}{l}\text { NOTE: When this step is initiated, a series of steps will be performed automatically. } \\
\text { Press "OPEN PORT" on the "PORT DO-07-203 MENU". } \\
\text { Message "PORT OPENING..." should be displayed on the OIU screen. }\end{array}$ & $\begin{array}{l}\text { Verify that the "PORT } \\
\text { OPENING..." message is displayed. }\end{array}$ & $\checkmark$ & & \\
\hline 11 & The drum centering clamps should extend to center the drum. & $\begin{array}{l}\text { Verify that the drum centering } \\
\text { clamps extend to center the drum. }\end{array}$ & $\checkmark$ & & \\
\hline 12 & The vacuum system should be activated by the PCS. & $\begin{array}{l}\text { Verify that the vacuum system is } \\
\text { activated. }\end{array}$ & 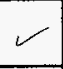 & & \\
\hline 13 & The HVAC seal should inflate. & $\begin{array}{l}\text { Verify that the HVAC seal is } \\
\text { inflated. }\end{array}$ & $\checkmark$ & & $K / 2$ \\
\hline 14 & $\begin{array}{l}\text { The PCS should energize vent vaives FEV-913A\&B, thereby releasing pressure on the door open/close } \\
\text { cylinders. }\end{array}$ & $\begin{array}{l}\text { Verify that vent valves FEV- } \\
913 \mathrm{~A} \& \mathrm{~B} \text { are energized. }\end{array}$ & V & & \\
\hline 15 & The port door locking bolts should both retract. & Verify that both locking bolts retract. & -4 & Qis & KhN \\
\hline 16 & The lift table servo motor should raise the drum to the Door in Position height and then stop. & $\begin{array}{l}\text { Verify that the door is raised to the } \\
\text { Door in Position height and then } \\
\text { stops. }\end{array}$ & & $*$ & \\
\hline 17 & $\begin{array}{l}\text { The port door open cylinders should raise the port door to the open position. } \\
\text { The drum lid should remain attached to the port door. }\end{array}$ & $\begin{array}{l}\text { Verify that the port door raises to the } \\
\text { open position. } \\
\text { Verify that the drum lid remains } \\
\text { attached to the port door. }\end{array}$ & & $\checkmark$ & $K 1$ \\
\hline
\end{tabular}

$$
\text { * See T.E. } 10
$$


HNF-SD-W026-ATR-021 Rev. 1

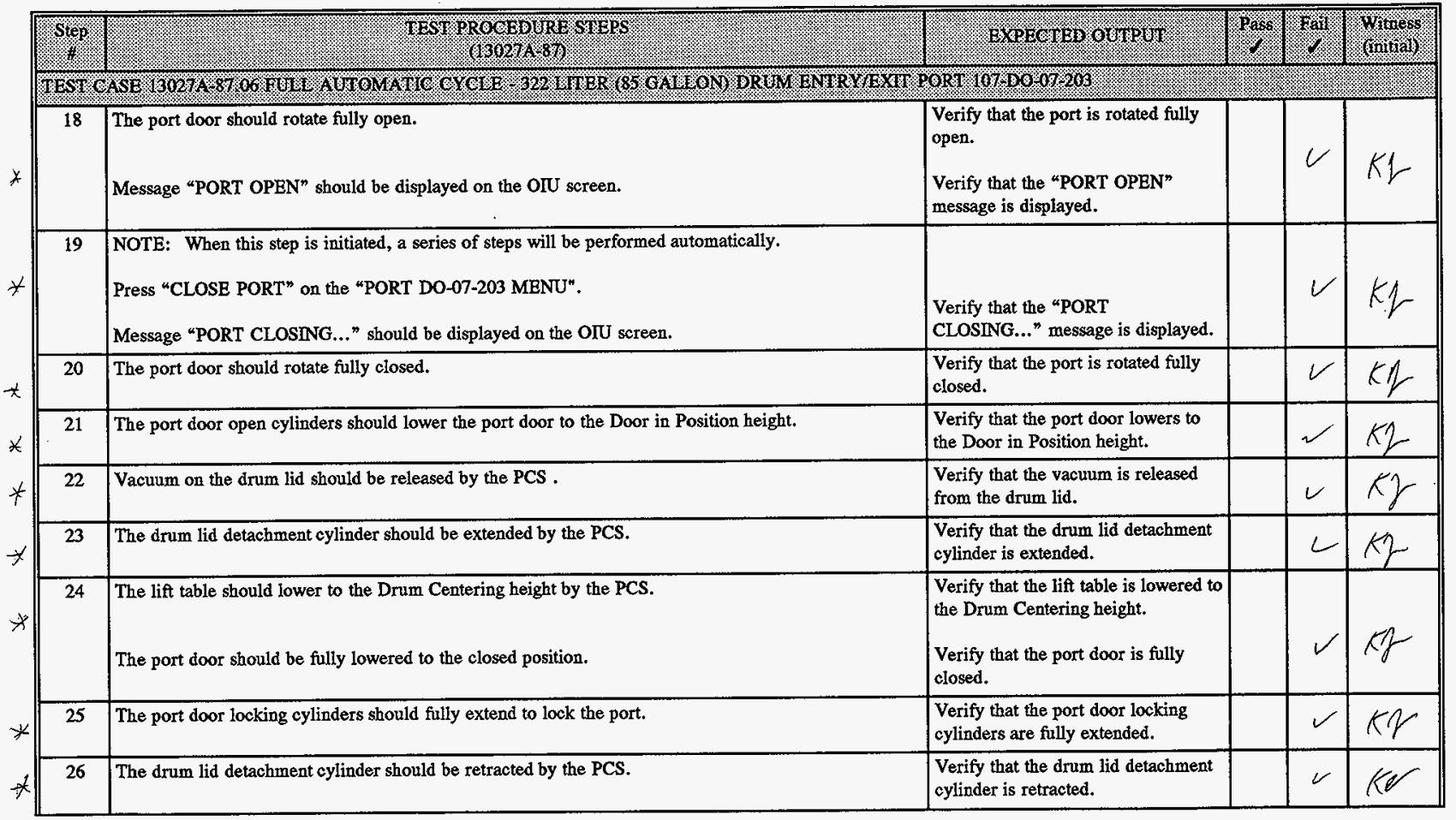

$$
\text { * See } \frac{\pi}{12} 10
$$


HINF-SD-W026-ATR-021 Rev. 1

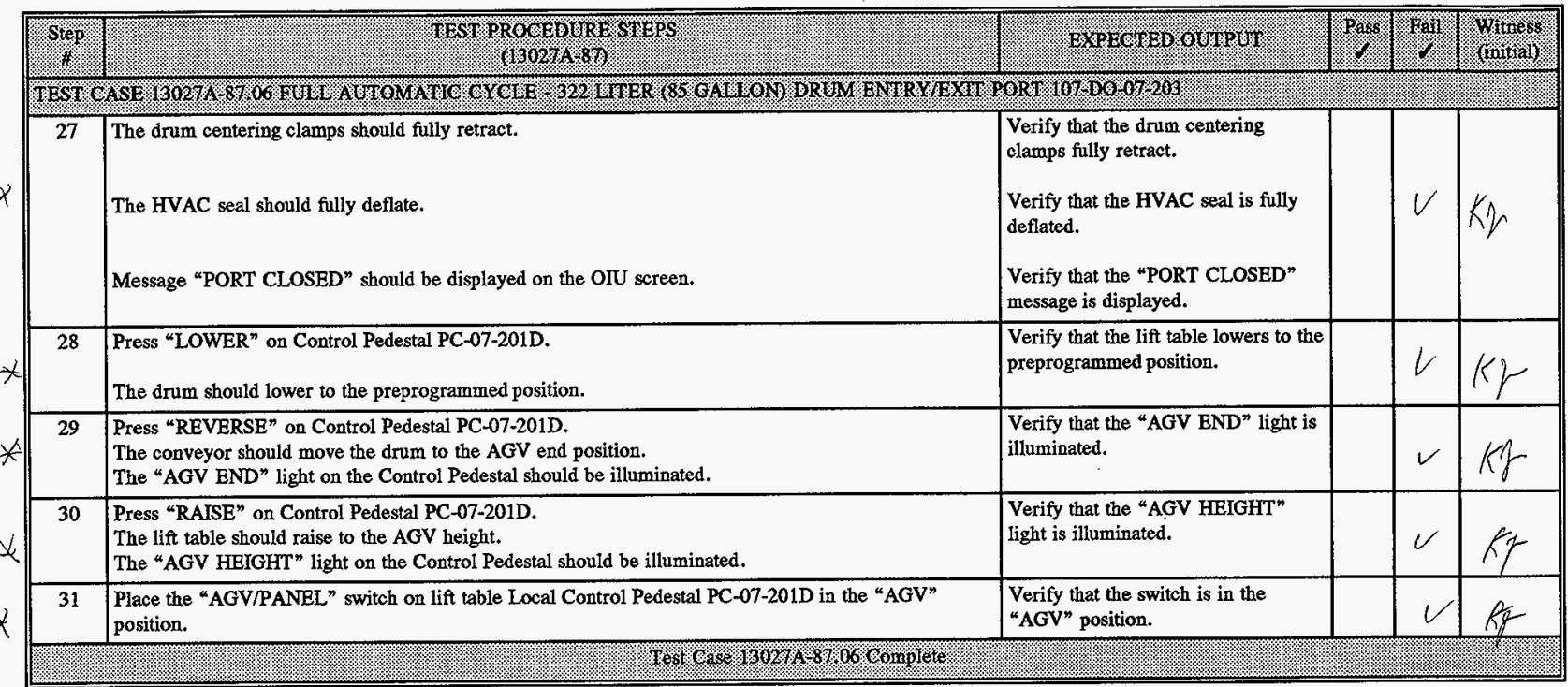

$$
A \sec T E \# 10
$$


HNF-SD-W026-ATR-021 Rev. 1

\begin{tabular}{|c|c|c|c|c|c|}
\hline Sien. & (IEST PROOEDURE SILPS & EXEETED OUTPUT & P. & Eain & (rintinil: \\
\hline \multicolumn{6}{|c|}{ 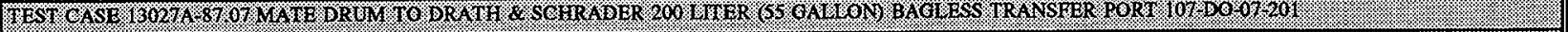 } \\
\hline & 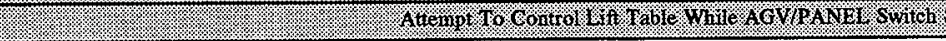 & W & ㄴ. & & \\
\hline 1 & Turn "AGV/PANEL" switch to "AGV". & $\begin{array}{l}\text { Verify that "AGV/PANEL" switch is } \\
\text { turned to "AGV" position. }\end{array}$ & i & & \\
\hline 2 & $\begin{array}{l}\text { Activate the lift table "RAISE" and "LOWER" pushbuttons at the lift table local control pedestal (107- } \\
\text { PC-09-201F) to attempt to raise and lower the lift table. } \\
\text { Because the "AGV/PANEL" switch is turned to the "AGV" position, the lift table should not raise or } \\
\text { lower. }\end{array}$ & $\begin{array}{l}\text { Verify that activating the "RAISE" } \\
\text { and "LOWBR" pushbuttons has no } \\
\text { effect on the lift table. }\end{array}$ & $V$ & & \\
\hline 3 & $\begin{array}{l}\text { Activate the lift table "FORWARD" and "REVERSE" pushbuttons at the lift table local control } \\
\text { pedestal (107-PC-09-201F) to attempt to activate the lift table roller conveyor. } \\
\text { Because the "AGV/PANEL" switch is turned to the "AGV" position, the lift table roller conveyor } \\
\text { should not activate. }\end{array}$ & $\begin{array}{l}\text { Verify that activating the } \\
\text { "FORWARD" and "REVERSE" } \\
\text { pushbuttons has no effect on the lift } \\
\text { table. }\end{array}$ & $V$ & & \\
\hline $\overrightarrow{4}$ & $\begin{array}{l}\text { Set the Lift Table Local Control Pedestal AGV/PANEL switch (09-HS-231D) to "PANEL" to allow an } \\
\text { operator to activate and control (via the PCS) the lift table (107-LT-09-201F). }\end{array}$ & $\begin{array}{l}\text { Verify that the lift table } \\
\text { AGV/PANEL switch is switched to } \\
\text { the "PANEL" position. }\end{array}$ & $V$ & & \\
\hline
\end{tabular}


HNF-SD-W026-ATR-021 Rev. 1

\begin{tabular}{|c|c|c|c|c|c|}
\hline Step & 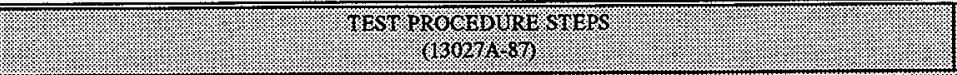 & Exremterpoutror & Pas. & (5) & (ingin \\
\hline \multicolumn{6}{|c|}{ 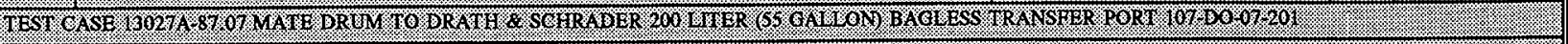 } \\
\hline \multicolumn{6}{|c|}{ 1. } \\
\hline $6 r^{g}$ & $\begin{array}{l}\text { Activate the lift table "LOWER" pushbutton at (107-PC-09-201F) as needed to lower the lift table until } \\
\text { the lift table is not at AGV Height. } \\
\text { on } \\
\text { The "AGV HEIGHT" indicator on the lift table local control pedestal should not be illuminated. }\end{array}$ & $\begin{array}{l}\text { Verify that the "AGV HEIGHT" } \\
\text { indicator is not illuminated. }\end{array}$ & & & \\
\hline $5 x$ & $\begin{array}{l}\text { At Lift Table Control Pedestal 107-PC-09-201F place "M/O/N" switch to " } \mathrm{M"} \\
\text {-il| }|0| 9 \mid\end{array}$ & $\begin{array}{l}\text { Verify that Lift Table Control } \\
\text { Pedestal } 107-P D-09-201 \mathrm{~F} \text { "M/O/N" } \\
\text { switch is set to "M". }\end{array}$ & . & & \\
\hline 7 & $\begin{array}{l}\text { NOTE: To open the Bagless Transfer Port, a drum must be mated to the port and the manipulator } \\
\text { must be parked. If either or both of these conditions is not met, the port should not open. } \\
\text { Because a drum is not mated to the port, the port should not open. } \\
\text { Turn on the Bagless Transfer Port control panel and in the "Full Automatic" Mode, attempt to initiate } \\
\text { the "DOUBLE LID OPEN AUTOMATIC" sequence by pressing the "START" button. }\end{array}$ & $\begin{array}{l}\text { Verify that the Bagless Transfer Port } \\
\text { does not open. }\end{array}$ & & & \\
\hline 8 & $\begin{array}{l}\text { Press the "PORT DO-07-201 MENU" button from the "LLW RWM GLOVEBOX MAIN MENU" at } \\
\text { OIU-12-105B. } \\
\text { NOTE: The selection of this button should cause the PCS to check the status of the "Drum at End of } \\
\text { Conveyor" position switch (09-ZS-231E) to determine if an empty drum is present at the } \\
\text { AGV end of the lift table and check the status of the "AGV Mating Height" position switch } \\
\text { (09-ZS-231G) to determine if the lift table is at AGV height. } \\
\text { Because the lift table is not at AGV height and no drum is present, OIU-12-105B should display a "NO } \\
\text { DRUM AT LIFT TABLE" message. }\end{array}$ & $\begin{array}{l}\text { Verify that OIU-12-105B displays the } \\
\text { "NO DRUM AT LIFT TABLE" } \\
\text { message. }\end{array}$ & & & \\
\hline
\end{tabular}


HNF-SD-W026-ATR-021 Rev. 1

\begin{tabular}{|c|c|c|c|c|c|}
\hline Step & "TST PROCEDVRE TIETS & EXPEGTED OHIPUT & (1) & (5) & Witingsis \\
\hline \multicolumn{6}{|c|}{ 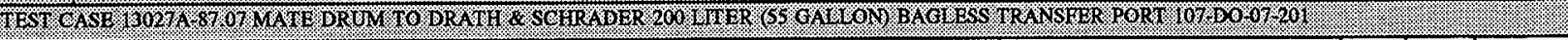 } \\
\hline 9 & $\begin{array}{l}\text { NOTE: To open the Bagless Transfer Port, a drum must be mated to the port and the manipulator } \\
\text { must be parked. If either or both of these conditions is not met, the port should not open. } \\
\text { Press the "OPEN PORT" button from the "PORT DO-07-201 MENU" at OIU 107-OIU-12-105B to } \\
\text { attempt to open the Bagless Transfer Port. } \\
\text { Because a drum is not mated to the port, the port should not open. }\end{array}$ & $\begin{array}{l}\text { Verify that the Bagless Transfer Port } \\
\text { does not open. }\end{array}$ & V & & 2 \\
\hline 10 & $\begin{array}{l}\text { Place the } 208 \text { liter ( } 55 \text { gallon) Drath \& Schrader drum with non-compliant item transfer stand, with } \\
\text { non-compliant packet, with inner drum lid, and without band clamp on the LLW RWM Bagless } \\
\text { Transfer Port Lift Table, (107-LT-09-201F). The drum should be placed at the AGV end of the lift } \\
\text { table. } \\
\text { "AGV END" should be illuminated on the Lift Table Control Pedestal (107-LT-09-201F), indicating } \\
\text { that the drum is located at the AGV end of the conveyor. }\end{array}$ & $\begin{array}{l}\text { Verify that the Drath \& Schrader } \\
\text { drum has been placed on the LLW } \\
\text { RWM Glovebox Bagless Transfer } \\
\text { Port lift table (107-LT-09-201F). } \\
\text { Verify that there is no band clamp on } \\
\text { the drum. } \\
\text { Verify that "AGV END" is } \\
\text { illuminated. }\end{array}$ & $\checkmark$ & & \\
\hline
\end{tabular}


HNF-SD-W026-ATR-021 Rev. 1

\begin{tabular}{|c|c|c|c|c|c|}
\hline Step. & TEST PRO OEDUR W SWEPS & EXPECTED OUTPOY & 18 & 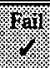 & \\
\hline \multicolumn{6}{|c|}{ 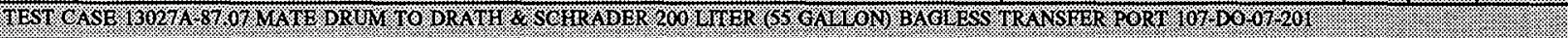 } \\
\hline (2. & 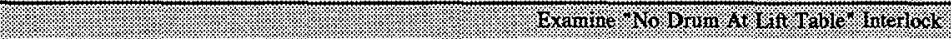 & (3. & & & \\
\hline 11 & $\begin{array}{l}\text { Review the "PORT DO-07-201 MENU" screen at OIU-12-105B. } \\
\text { NOTE: The PCS should continue to check the status of the "Drum at end of Conveyor" position } \\
\text { switch to determine if an empty drum is present at the AGV end of the lift table and check } \\
\text { the status of the "AGV Mating Height" position switch (09-ZS-231G) to determine if the lift } \\
\text { table is at AGV height. } \\
\text { Because the lift table is not at AGV height, OIU-12-105B should display a "NO DRUM AT LIFT } \\
\text { TABLE" message. } \\
\text { Step does not matke sense as AGV is wO cered ast }\end{array}$ & $\begin{array}{l}\text { Verify that OIU-12-105B displays the } \\
\text { "NO DRUM AT LIFT TABLE" } \\
\text { message. }\end{array}$ & & & \\
\hline 12 & At Lift Table Control Pedestal 107-PC-201F place "M/O/N" switch to "NORAFAL" MAINITENAARE & $\begin{array}{l}\text { Verify that Lift Table Control } \\
\text { Pedestal 107-PD-09-201F "M/O/N" } \\
\text { switch is set to "NORMAL". }\end{array}$ & $V$ & & \\
\hline 13 & $\begin{array}{l}\text { Activate the lift table "RAISE" pushbutton at the lift table local control pedestal (107-PC-09-201F) as } \\
\text { needed to raise the lift table to AGV Height. } \\
\text { "AGV HEIGHT" should be illuminated on the Lift Table Control Pedestal (107-LT-09-201F), } \\
\text { indicating that the lift table is at AGV height. }\end{array}$ & $\begin{array}{l}\text { Visually verify that the Lift Table } \\
(107-\mathrm{LT}-09-201 \mathrm{~F}) \text { is at AGV height. } \\
\text { Verify that "AGV HEIGHT" is } \\
\text { illuminated. }\end{array}$ & & & \\
\hline 14 & $\begin{array}{l}\text { Examine the "PORT DO-07-201 MENU" screen at OIU-12-105B. } \\
\text { FURCE A } A G V \text { Status Bit Ni37: } 106 / 12 \\
\text { Because a drum is present and the lift table is at AGV height, OIU-12-105B should display a "DRUM } \\
\text { AT LIFT TABLE" message. }\end{array}$ & $\begin{array}{l}\text { Verify that OIU-12-105B displays a } \\
\text { "DRUM AT LIFT TABLE" } \\
\text { message. }\end{array}$ & $\sim$ & & $K Q_{2}$ \\
\hline
\end{tabular}


HNF-SD-W026-ATR-021 Rev. 1

\begin{tabular}{|c|c|c|c|c|c|}
\hline step & 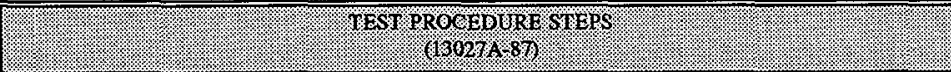 & 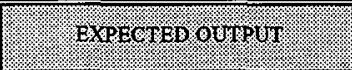 & ras. & riat: & Writiving \\
\hline \multicolumn{6}{|c|}{ 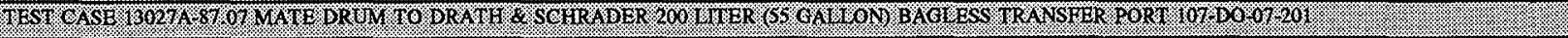 } \\
\hline צ: & 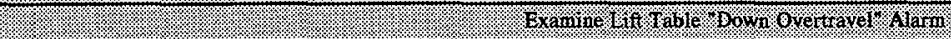 & ( & & & \\
\hline 15 & $\begin{array}{l}\text { Manually activate the "Down Overtravel" position switch (09-ZS-231C) to simulate that the lift table } \\
\text { (107-LT-09-201F) has been lowered below its normal travel height. } \\
\text { The "DOWN OVERTRAVEL" status indicator (09-ZL-231C) at the Lift Table Local Control Pedestal } \\
\text { (107-PC-09-201F) should be illuminated, indicating that the "Down Overtravel" position switch (09- } \\
\text { ZS-231C) has been activated. }\end{array}$ & $\begin{array}{l}\text { Verify that the "Down Overtravel" } \\
\text { position switch (09-ZS-231C) is } \\
\text { activated. } \\
\text { Verify that the "DOWN } \\
\text { OVERTRAVEL" indicator (09-ZL- } \\
\text { 231C) is illuminated. }\end{array}$ & & & \\
\hline 16 & $\begin{array}{l}\text { Activate the lift table "LOWER" pushbuttons at the lift table local control pedestal (107-PC-09-201F) } \\
\text { to attempt energize lift table motor } 107-\mathrm{LT}-09-201 \mathrm{~F} / \mathrm{M} 1 \text {. } \\
\text { Because the lift table overtravel switch is activated, the lift table should not lower. }\end{array}$ & $\begin{array}{l}\text { Verify that the lift table does not } \\
\text { lower. }\end{array}$ & V & & \\
\hline 17 & $\begin{array}{l}\text { Review the "PORT DO-07-201 MENU" status. A flashing "SEQUENCE FAILED" message should } \\
\text { be displayed and the "ALARMS" button should be flashing. } \\
\text { Press the "ALARMS" button. The "LOCAL ALARMS" screen should be displayed, with a flashing } \\
\text { "Lift Table (201F) Down Overtravel" alarm. } \\
\text { Press the "LOCAL ALARMS" screen to display the "LOCAL ALARMS" screen. Buttons should be } \\
\text { displayed near the bottom of the screen to allow alarms to be acknowledged. An active "Lift Table } \\
\text { (201F) Down Overtravel" alarm should be displayed on this screen. }\end{array}$ & $\begin{array}{l}\text { Verify that a flashing "SEQUENCE } \\
\text { FAILED" message is displayed and } \\
\text { the "ALARMS" button is flashing. } \\
\text { Verify that the "LOCAL ALARMS" } \\
\text { screen is displayed with the active } \\
\text { alarm flashing. } \\
\text { Verify that the "ACTIVE ALARMS" } \\
\text { screen with an active "Lift Table } \\
\text { (201F) Down Overtravel" alarm is } \\
\text { displayed. }\end{array}$ & & & \\
\hline
\end{tabular}


HNF-SD-W026-ATR-021 Rev. 1

\begin{tabular}{|c|c|c|c|c|c|}
\hline Siton: & TEST PROCGDURL STIEPS & EXPECTEO OUTPUI & Pass. & Fain & $\begin{array}{l}\text { Whaness } \\
\text { (rinitial }\end{array}$ \\
\hline \multicolumn{6}{|c|}{ 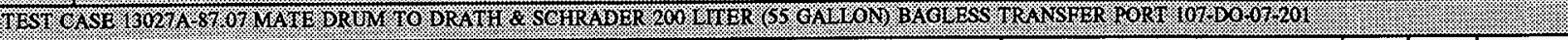 } \\
\hline 18 & $\begin{array}{l}\text { Press the bottom area of the "LOCAL ALARMS" screen to activate the alarm selector feature. The } \\
\text { currently selected alarm should be highlighted. Press the up and down arrow buttons as needed to } \\
\text { select the appropriate alarm. } \\
\text { Press the "ACK" button to acknowledge the selected alarm. } \\
\text { Press the "DONE" button to return to the "LOCAL ALARMS" screen. }\end{array}$ & $\begin{array}{l}\text { Verify that the appropriate alarm is } \\
\text { selected (highlighted). } \\
\text { Verify that the selected alarm is } \\
\text { acknowledged. } \\
\text { Verify that the "LOCAL ALARMS" } \\
\text { screen is displayed and that the } \\
\text { acknowledged "Lift Table (201F) } \\
\text { Down Overtravel" alarm is displayed } \\
\text { on this screen. }\end{array}$ & $V$ & & \\
\hline 19 & $\begin{array}{l}\text { Manually reset the "Down Overtravel" position switch (09-ZS-231C) to indicate that the lift table (107- } \\
\text { LT-09-201F) is positioned within its normal vertical travel range. } \\
\text { Resetting the "Down Overtravel" position switch (09-ZS-231C) should cause the "Lift Table (201F) } \\
\text { Down Overtravel" alarm to clear. } \\
\text { The "DOWN" Overtravel status indicator (09-ZL-231C) at the Lift Table Local Control Pedestal (107- } \\
\text { PC-09-201F) should not be illuminated, indicating that the "Down Overtravel" position switch (09-ZS- } \\
231 \mathrm{C} \text { ) is not activated. }\end{array}$ & $\begin{array}{l}\text { Verify that the steady yellow alarm } \\
\text { message has changed to green. } \\
\text { Verify that the "Lift Table (201F) } \\
\text { Down Overtravel" alarm is cleared. } \\
\text { Verify that the "DOWN" Overtravel } \\
\text { status indicator (09-ZL-231C) is not } \\
\text { illuminated. }\end{array}$ & & & \\
\hline 20 & Press the "RETURN TO CURRENT SCREEN" button to return to the "PORT DO-07-201 MENU" & $\begin{array}{l}\text { Verify that the "PORT DO-07-201 } \\
\text { MENU" is displayed with a "DRUM } \\
\text { AT LIFT TABLE" message. }\end{array}$ & $\swarrow$ & & \\
\hline
\end{tabular}




\begin{tabular}{|c|c|c|c|c|c|}
\hline Pax & & $\Lambda$ & 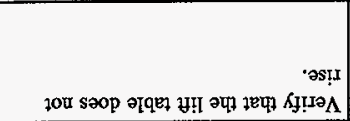 & 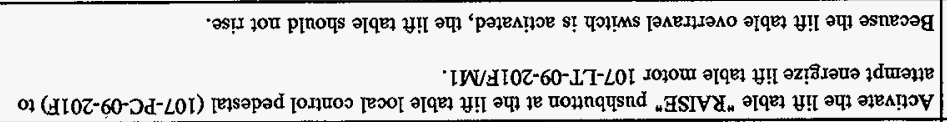 & $t z$ \\
\hline & & $\Lambda$ & 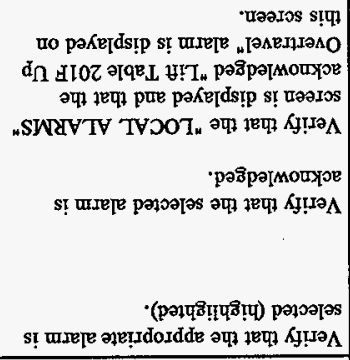 & 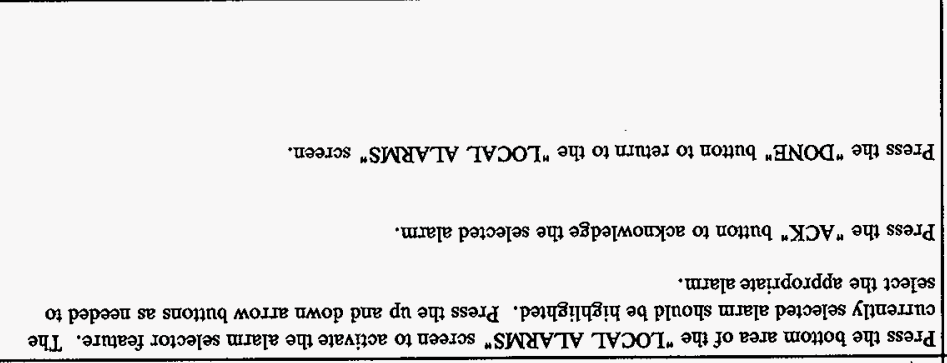 & $\varepsilon z$ \\
\hline miv & & $\Lambda$ & 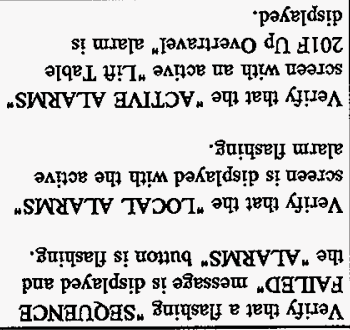 & 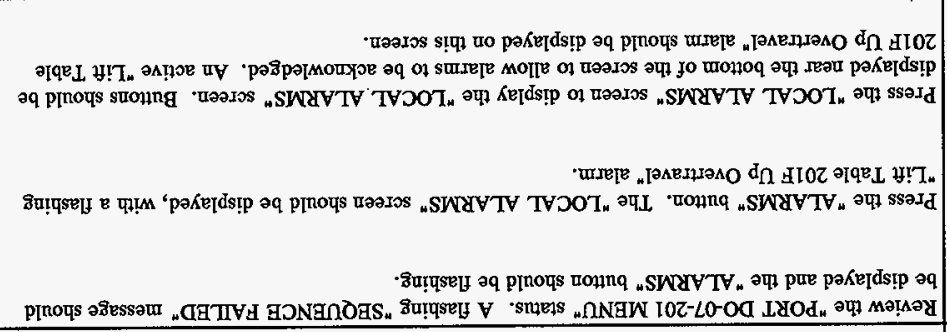 & $z \tau$ \\
\hline$\sqrt{6}$ & & $\beta$ & 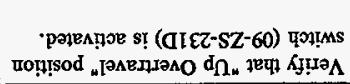 & 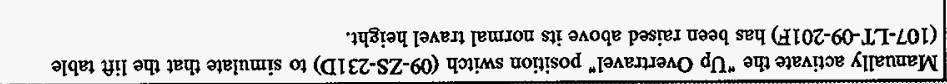 & $\mathfrak{i z}$ \\
\hline & & & (2) & initr. & (2:- \\
\hline & & & 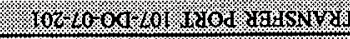 & 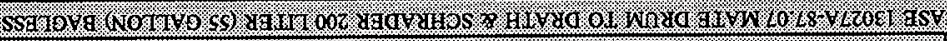 & \% \\
\hline 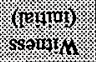 & 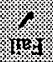 & 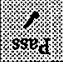 & Malino gar oraxa & 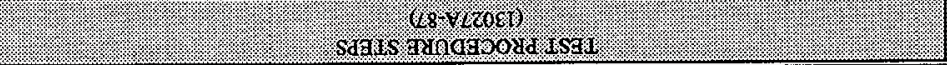 & 16: \\
\hline
\end{tabular}

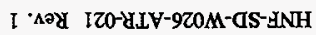

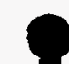




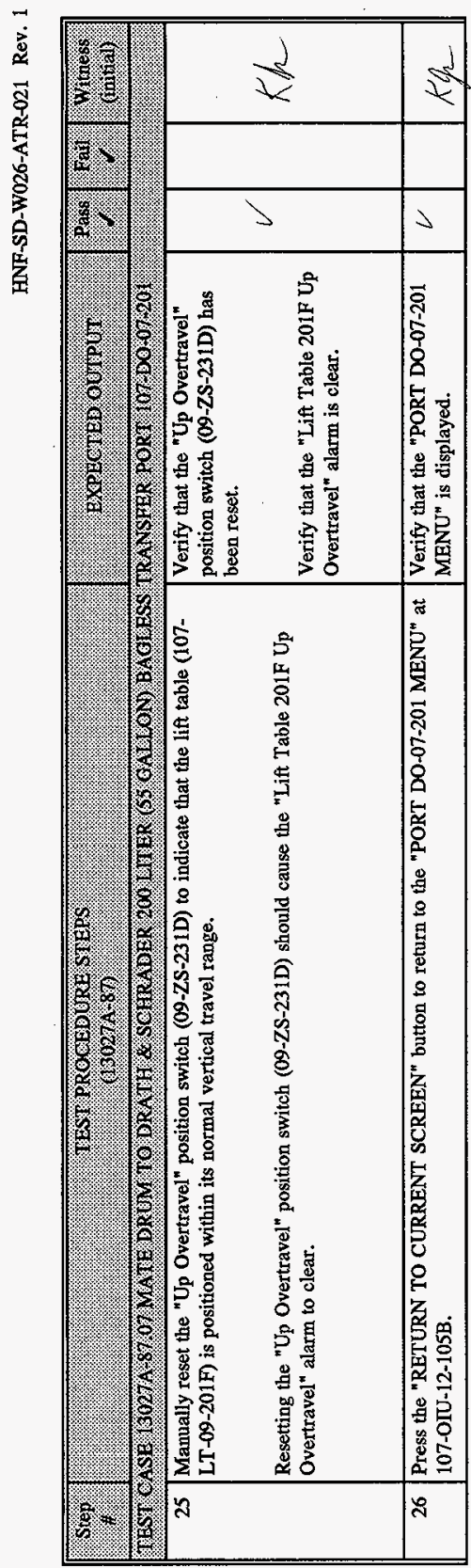

尊

$\stackrel{\infty}{5}$

5 


\begin{tabular}{|c|c|c|c|c|c|}
\hline Step & TEST PRGCEDURT SILPS & EXPECTED OUYPOT & rast & rition: & (ritivess \\
\hline \multicolumn{6}{|c|}{ 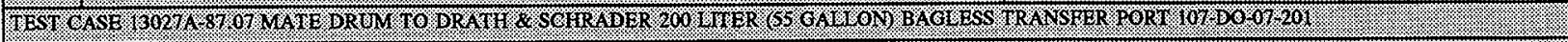 } \\
\hline & 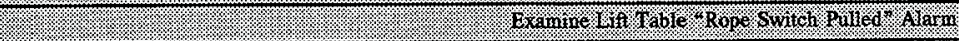 & & & & \\
\hline 27 & $\begin{array}{l}\text { Pull the Lift Table (107-LT-09-201F) Rope Switches (09-XS-231A/B) to disable all lift table } \\
\text { operations. } \\
\text { Press all pushbuttons on the Lift Table Local Control Pedestal (107-PC-09-201F) in both "Normal" and } \\
\text { "Maintenance" modes (Use Lift Table Local Control Pedestal M/O/N switch to switch between } \\
\text { operating modes). Because the rope switches have been pulled, pressing the buttons should have no } \\
\text { effect on the lift table. }\end{array}$ & $\begin{array}{l}\text { Verify that the rope switches have } \\
\text { been pulled. } \\
\text { Verify that pressing the Lift Table } \\
\text { Local Control Pedestal pushbuttons } \\
\text { have no effect on the lift table. }\end{array}$ & $\sqrt{ }$ & & \\
\hline 28 & $\begin{array}{l}\text { Review the "PORT DO-07-201 MENU" status. A flashing "SEQUENCE FALED" message should } \\
\text { be displayed and the "ALARMS" button should be flashing. } \\
\text { Press the "ALARMS" button. The "LOCAL ALARMS" screen should be displayed, with a flashing } \\
\text { "Lift Table (201F) Rope Sw. Pulled" alarm. } \\
\text { Press the "LOCAL ALARMS" screen to display the "LOCAL ALARMS" screen. Buttons should be } \\
\text { displayed near the bottom of the screen to allow alarms to be acknowledged. An active "Lift Table } \\
\text { (201F) Rope Sw. Pulled" alarm should be displayed on this screen. }\end{array}$ & $\begin{array}{l}\text { Verify that a flashing "SEQUENCE } \\
\text { FAILED" message is displayed and } \\
\text { the "ALARMS" button is flashing. } \\
\text { Verify that the "LOCAL ALARMS" } \\
\text { screen is displayed with the active } \\
\text { alarm flashing. } \\
\text { Verify that the "ACTIVE ALARMS" } \\
\text { screen with an active "Lift Table } \\
\text { (201F) Rope Sw. Pulled" alarm is } \\
\text { displayed. }\end{array}$ & $V$ & & $\pi$ \\
\hline 29 & $\begin{array}{l}\text { Press the bottom area of the "LOCAL ALARMS" screen to activate the alarm selector feature. The } \\
\text { currently selected alarm should be highlighted. Press the up and down arrow buttons as needed to } \\
\text { select the appropriate alarm. } \\
\text { Press the "ACK" button to acknowledge the selected alarm. } \\
\text { Press the "DONE" button to return to the "LOCAL ALARMS" screen. }\end{array}$ & $\begin{array}{l}\text { Verify that the appropriate alarm is } \\
\text { selected (highlighted). } \\
\text { Verify that the selected alarm is } \\
\text { acknowledged. } \\
\text { Verify that the "LOCAL ALARMS" } \\
\text { screen is displayed and that the } \\
\text { acknowledged "Lift Table (201F) } \\
\text { Rope Sw. Pulled" alarm is displayed } \\
\text { on this screen. }\end{array}$ & $V$ & & \\
\hline
\end{tabular}


HNF-SD-W026-ATR-021 Rev. 1

\begin{tabular}{|c|c|c|c|c|c|}
\hline Ster: & (1. TEST PROCEDURT STEPS & EXPEQTEPOUTPUI & Thaso & Fail & (Fintials \\
\hline \multicolumn{6}{|c|}{ 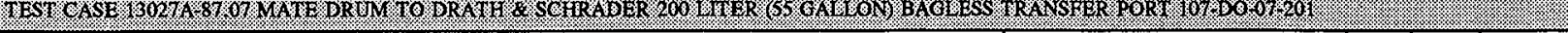 } \\
\hline 30 & $\begin{array}{l}\text { Manually reset the Lift Table Rope Switches (09-XS-231A/B) to allow normal lift table operation. } \\
\text { Resetting the Lift Table Rope switches (09-XS-231A/B) should cause the "Lift Table 201F Rope } \\
\text { Switch Pulled" alarm to clear. }\end{array}$ & $\begin{array}{l}\text { Verify that the Lift Table Rope } \\
\text { Switches have been reset. } \\
\text { Verify that the "Lift Table 201F } \\
\text { Rope Switch Pulled" alarm is } \\
\text { cleared. }\end{array}$ & $\checkmark$ & & Khr \\
\hline 31 & $\begin{array}{l}\text { Press the "RETURN TO CURRENT SCREEN" button to return to the "PORT DO-07-201 MENU" at } \\
\text { OIU-12-105B. }\end{array}$ & $\begin{array}{l}\text { Verify that the "PORT DO-07-201 } \\
\text { MENU" is displayed. }\end{array}$ & $\checkmark$ & & \\
\hline
\end{tabular}




\begin{tabular}{|c|c|c|c|c|c|}
\hline $3 y$ & & & 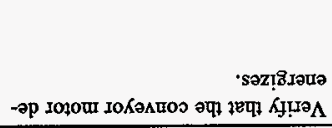 & 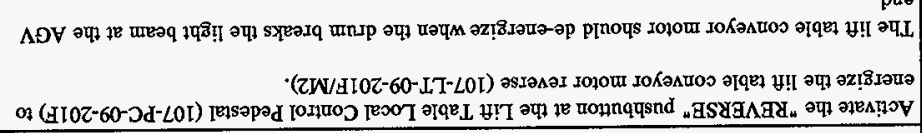 & $\varepsilon \varepsilon$ \\
\hline चy & & $\Lambda$ & 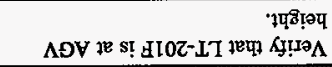 & 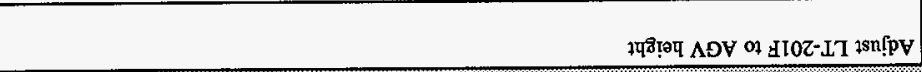 & $z \varepsilon$ \\
\hline & & & & 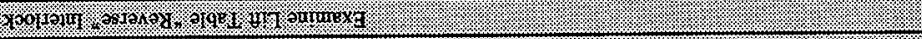 & $\sqrt{10}$ \\
\hline ssoming & (1) & sided & thads & 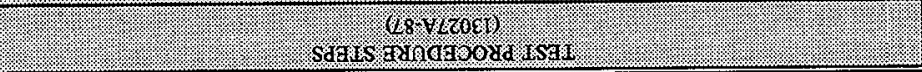 & dais \\
\hline
\end{tabular}


HNF-SD-W026-ATR-021 Rev. 1

\begin{tabular}{|c|c|c|c|c|c|}
\hline Sep: & 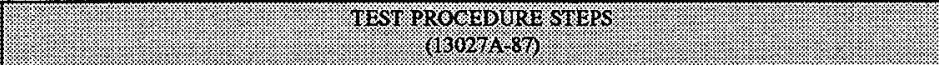 & 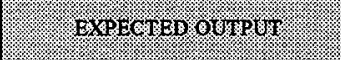 & Pats & riat & (rnitita) \\
\hline \multicolumn{6}{|c|}{ 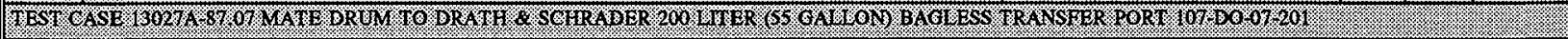 } \\
\hline & - & (1110. & & & \\
\hline 34 & $\begin{array}{l}\text { NOTE: This step will be used to simulate a power failure at the lift table. The } 480 \text { volt lift table } \\
\text { supply local disconnect will be opened during drum transfer under the glovebox port. } \\
\text { Activate the "FORWARD" pushbutton at the Lift Table Local Control Pedestal (107-PC-09-201F) to } \\
\text { energize the lift table conveyor motor forward (107-LT-09-201F/M2). After drum has moved } \\
\text { approximately one foot, open the } 480 \text { volt lift table disconnect to remove power from the lift table. } \\
\text { The roller conveyor should stop. After approximately } 10 \text { seconds, close the } 480 \text { volt lift table } \\
\text { disconnect to restore power to the lift table. The roller conveyor should not start up again after power } \\
\text { is restored. }\end{array}$ & $\begin{array}{l}\text { Verify that the drum is moving } \\
\text { forward. } \\
\text { Verify that the lift table roller } \\
\text { conveyors have stopped and remain } \\
\text { stopped. }\end{array}$ & & & \\
\hline 35 & $\begin{array}{l}\text { Review the "PORT DO-07-201 MENU" status. A flashing "SEQUENCE FAILED" message should } \\
\text { be displayed and the "ALARMS" button should be flashing. } \\
\text { Press the "ALARMS" button. The "LOCAL ALARMS" screen should be displayed, with a flashing } \\
\text { "Lift Table (201F) Conv. Fwd Failed" alarm. } \\
\text { Press the "LOCAL ALARMS" screen to display the "LOCAL ALARMS" screen. Buttons should be } \\
\text { displayed near the bottom of the screen to allow alarms to be acknowledged. An active "Lift Table } \\
\text { (201F) Conv. Fwd Failed" alarm should be displayed on this screen. }\end{array}$ & $\begin{array}{l}\text { Verify that a flashing "SEQUENCE } \\
\text { FAIIED" message is displayed and } \\
\text { the "ALARMS" button is flashing. } \\
\text { Verify that the "LOCAL ALARMS" } \\
\text { screen is displayed with the active } \\
\text { alarm flashing. } \\
\text { Verify that the "LOCAL ALARMS" } \\
\text { screen with an active "Lift Table } \\
\text { (201F) Conv. Fwd Failed" alarm is } \\
\text { displayed. }\end{array}$ & 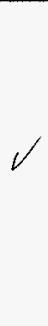 & & \\
\hline
\end{tabular}




\begin{tabular}{|c|c|c|c|c|c|}
\hline ry & & $\Lambda$ & 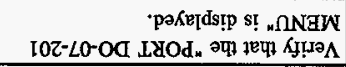 & 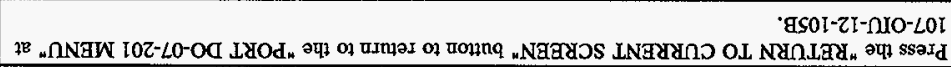 & $L \mathcal{E}$ \\
\hline$-6 y$ & & $\Lambda$ & 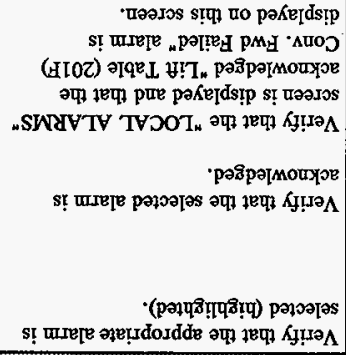 & 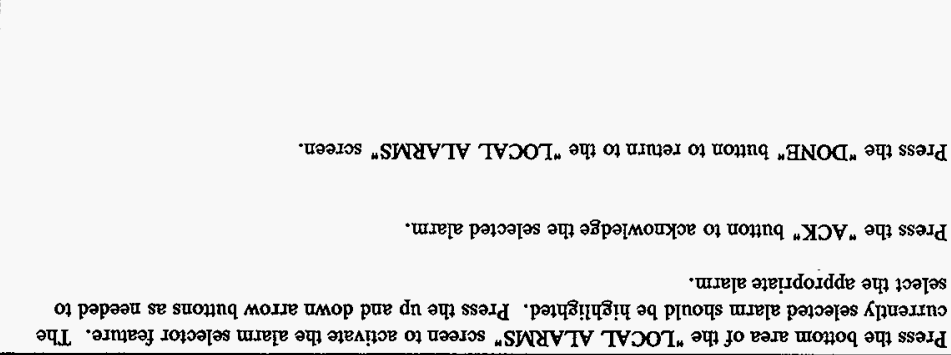 & $9 \mathcal{E}$ \\
\hline & & & 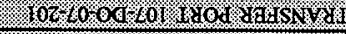 & 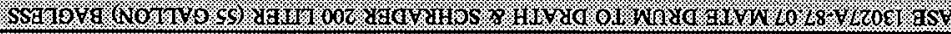 & $3 \mathrm{ses}$ \\
\hline (renging) & 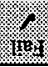 & 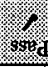 & 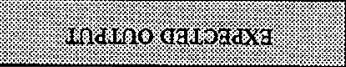 & 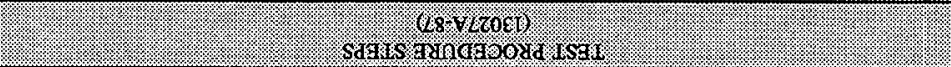 & it: \\
\hline
\end{tabular}


HNF-SD-W026-ATR-021 Rev. 1

\begin{tabular}{|c|c|c|c|c|c|}
\hline Step: & TEST PROUEDURE STEPS. & EXPET TED OWPOT: & Pros. & t. & (winitial) \\
\hline \multicolumn{6}{|c|}{ 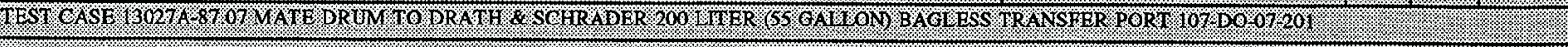 } \\
\hline \multicolumn{6}{|c|}{ 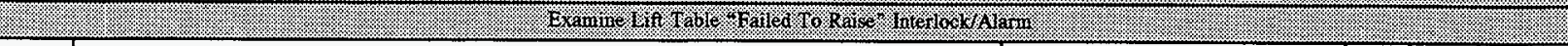 } \\
\hline 38 & $\begin{array}{l}\text { Activate the lift table "RAISE" pushbutton at the lift table local control pedestal (107-PC-09-201F) to } \\
\text { attempt energize lift table motor 107-LT-09-201F/M1. } \\
\text { Because a drum is not present under the Entry/Exit.Port, as indicated by position switch 09-ZS-231F, } \\
\text { the "RAISE" pushbutton should be disabled by the PCS. }\end{array}$ & $\begin{array}{l}\text { Verify that the lift table does not } \\
\text { rise. }\end{array}$ & $V$ & & \\
\hline 39 & $\begin{array}{l}\text { Change LT 201F "Failed to Raise" TD from current value to } 5 \text { sec. Record register contents. } \\
\text { L5 Register:_T4:109 Contents: }\end{array}$ & $\begin{array}{l}\text { Verify LT } 201 \mathrm{~F} \mathrm{TD} \mathrm{is} \mathrm{set} \mathrm{to} 5 \mathrm{sec} . \\
\text { and record register contents. }\end{array}$ & $\checkmark$ & & \\
\hline 40 & $\begin{array}{l}\text { Activate the "FORWARD" pushbutton at the Lift Table Local Control Pedestal (107-PC-09-201F) to } \\
\text { energize the lift table conveyor motor forward (107-LT-09-201F/M2) until the drum is centered } \\
\text { underneath the Bagless Transfer Port (107-DO-07-201). } \\
\text { The "DRUM UNDER PORT" status indicator (09-ZL-231B) at the Lift Table Local Control Pedestal } \\
\text { (107-PC-09-201F) should be illuminated, indicating that the drum is centered under the port. }\end{array}$ & $\begin{array}{l}\text { Verify that the drum is centered } \\
\text { under the Bagless Transfer Port. } \\
\text { Verify that the "DRUM UNDER } \\
\text { PORT" status indicator (09-ZL- } \\
231 B \text { ) is illuminated. }\end{array}$ & $\checkmark$ & & \\
\hline
\end{tabular}


HNF-SD-W026-ATR-021 Rev. 1

\begin{tabular}{|c|c|c|c|c|c|}
\hline Stor & TEST PRO GEDTRE STERS . & 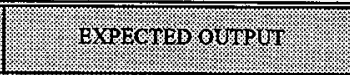 & rasis. & (2.1. & Wintiness \\
\hline \multicolumn{6}{|c|}{ 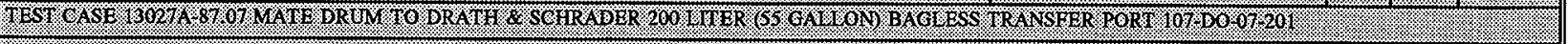 } \\
\hline \multicolumn{6}{|c|}{ 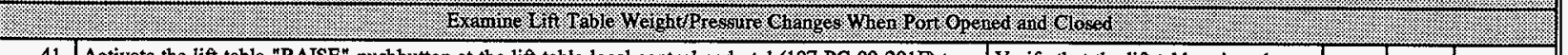 } \\
\hline 41 & $\begin{array}{l}\text { Activate the lift table "RAISE" pushbutton at the lift table local control pedestal (107-PC-09-201F) to } \\
\text { energize the lift table motor (107-LT-09-201F/M1) to raise the Lift Table. } \\
\text { The PCS should activate the lift table motor to raise the drum just below the Bagless Transfer Port. } \\
\text { The PCS should raise the lift table at slow speed until the drum contacts the port. The PCS should } \\
\text { continue to energize the lift table servo motor until the predetermined weight setpoint is reached. } \\
\text { Record the "Lift Table Weight" displayed on the "PORT DO-07-201 MENU" screen at OIU-12-105B: } \\
\text { Lift Table Weight: } \frac{650+94 \text { (setpont) }}{751 / K f} 773 \text { kilograms }\end{array}$ & $\begin{array}{l}\text { Verify that the lift table raises the } \\
\text { drum to contact the Bagless Transfer } \\
\text { Port. } \\
\text { Verify that the predetermined weight } \\
\text { set point displayed on the OIU-12- } \\
\text { 105B "PORT DO-07-201 MENU" } \\
\text { (established during setup of this } \\
\text { procedure) has been reached or } \\
\text { exceeded and is recorded in the } \\
\text { space provided. }\end{array}$ & & & \\
\hline 42 & $\begin{array}{l}\text { Review the "PORT DO-07-201 MENU" status. A flashing "SEQUENCE FAILED" message should } \\
\text { be displayed and the "ALARMS" button should be flashing. } \\
\text { Press the "ALARMS" button. The "LOCAL ALARMS" screen should be displayed, with a flashing } \\
\text { "Lit Table (201F) Failed to Raise" alarm. } \\
\text { Press the "LOCAL, ALARMS" screen to display the "LOCAL ALARMS" screen. Buttons should be } \\
\text { displayed near the bottom of the screen to allow alarms to be acknowledged. An active "Lift Table } \\
\text { (201F) Failed to Raise" alarm should be displayed on this screen. }\end{array}$ & $\begin{array}{l}\text { Verify that a flashing "SEQUENCE } \\
\text { FAILED" message is displayed and } \\
\text { the "ALARMS" button is flashing. } \\
\text { Verify that the "LOCAL ALARMS" } \\
\text { screen is displayed with the active } \\
\text { alarm flashing. } \\
\text { Verify that the "ACTIVE ALARMS" } \\
\text { screen with an active "Lift Table } \\
\text { (201F) Failed to Raise" alarm is } \\
\text { displayed. }\end{array}$ & & & \\
\hline
\end{tabular}


HNF-SD-W026-ATR-021 Rev. 1

\begin{tabular}{|c|c|c|c|c|c|}
\hline sicen. & TEST PRO WEDURE STERPS & EXPETIED OUTPYI & Pass & 6.1. & (rinitial) \\
\hline \multicolumn{6}{|c|}{ 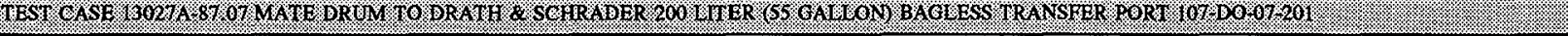 } \\
\hline 43 & $\begin{array}{l}\text { Press the bottom area of the "LOCAL ALARMS" screen to activate the alarm selector feature. The } \\
\text { currently selected alarm should be highlighted. Press the up and down arrow buttons as needed to } \\
\text { select the appropriate alarm. } \\
\text { Press the "ACK" button to acknowledge the selected alarm. } \\
\text { Press the "DONE" button to return to the "LOCAL ALARMS" screen. }\end{array}$ & $\begin{array}{l}\text { Verify that the appropriate alarm is } \\
\text { selected (highlighted). } \\
\text { Verify that the selected alarm is } \\
\text { acknowledged. } \\
\text { Verify that the "LOCAL ALARMS" } \\
\text { screen is displayed and that the } \\
\text { acknowledged "Lift Table (201F) } \\
\text { Failed to Raise" alarm is displayed } \\
\text { on this screen. }\end{array}$ & $\sqrt{ }$ & & $k$ ke \\
\hline 44 & Restore Register _ T4:109 to value recorded in step 39. & $\begin{array}{l}\text { Verify that Register } T 4: 109 \text { is } \\
\text { set to the correct value. }\end{array}$ & $V$ & & \\
\hline
\end{tabular}


HNF-SD-W026-ATR-021 Rev. 1

\begin{tabular}{|c|c|c|c|c|c|}
\hline Wtop & IFEST RROCEDURP STEPS & 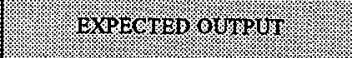 & r.s. & Farit. & (minitives) \\
\hline TES & 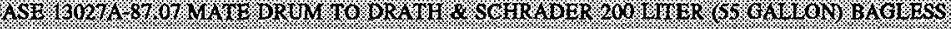 & (1)ER POPA & & & \\
\hline 45 & $\begin{array}{l}\text { Press the "OPEN PORT" button from the "PORT DO-07-201 MENU" at OIU-12-105B to open the } \\
\text { port. The Bagless Transfer Port should open. } \\
\text { The PCS should display a "PORT OPENING..." message at OIU-12-105B while the port is opening. } \\
\text { NOTE: Reaching the weight setpoint and not actuating the lift table overtravel switch should cause the } \\
\text { PCS to give an output (DO-07-201/O) to the Bagless Transfer Port (107-DO-07-201), which } \\
\text { signals the Bagless Transfer Port to open. Because the manipulator is parked and a drum is } \\
\text { mated to the port, the port door should open. The Bagless Transfer Port should send a signal } \\
\text { (DO-07-201/OS) to the PCS indicating that the port is open. }\end{array}$ & $\begin{array}{l}\text { Verify that a "OPEN PORT" } \\
\text { message is displayed after the port is } \\
\text { open. } \\
\text { Verify that the weight recorded with } \\
\text { the port open does not fall below the } \\
\text { "Lift Table Weight Setpoint" limit } \\
\text { listed on the "PORT DO-07-201 } \\
\text { MENU" screen. }\end{array}$ & $\begin{array}{l}\checkmark \\
1 \checkmark\end{array}$ & $V$ & \\
\hline
\end{tabular}


HNF-SD-W026-ATR-021 Rev. 1

\begin{tabular}{|c|c|c|c|c|c|}
\hline Stepl & (1) PST PROCFOURE GIEPS & 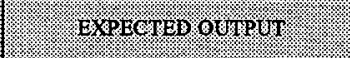 & Pats & Tain & \\
\hline \multicolumn{6}{|c|}{ 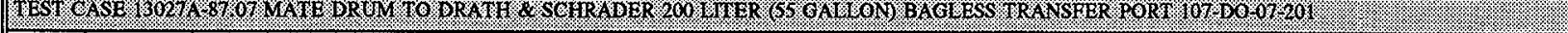 } \\
\hline 46 & $\begin{array}{l}\text { Press the "CLOSE PORT" button from the "PORT DO-07-201 MENU" at OIU-12-105B to close the } \\
\text { port. The Bagless Transfer Port door should close and lock. } \\
\text { The PCS should display a "PORT CLOSING..." message at OIU-12-105B while the port is closing. } \\
\text { NOTE: Pressing the "CLOSE PORT" button should cause the PCS to give an output (DO-07-201/C) } \\
\text { to the Bagless Transfer Port (107-DO-07-201), which signals the Bagless Transfer Port to } \\
\text { close. Because the manipulator is parked and a drum is mated to the port, the port door } \\
\text { should close. The Bagless Transfer Port should close and lock and send a signal (DO-07- } \\
\text { 201/CS) to the PCS indicating that the port is closed. } \\
\text { The PCS should then display a "PORT CLOSED" message at OIU-12-105B. } \\
\text { Record the "Lift Table Weight" displayed on the "PORT DO-07-201 MENU" screen at OIU-12-105B: } \\
\text { Lift Table Weight: } \\
\text { Ce } 3\end{array}$ & $\begin{array}{l}\text { Verify that the Bagless Transfer Port } \\
\text { door is closed and locked. } \\
\text { Verify that a "PORT CLOSING..." } \\
\text { message is displayed while the port } \\
\text { is closing. }\end{array}$ & $\checkmark$ & & \\
\hline
\end{tabular}


HNF-SD-W026-ATR-021 Rev. 1

\begin{tabular}{|c|c|c|c|c|c|}
\hline Sto. & TEST PROQEDTREY STERS & PXPECTED OHYIR & Pas. & (1) & (3ininit) \\
\hline \multicolumn{6}{|c|}{ 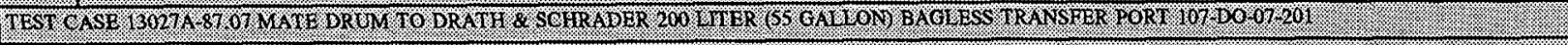 } \\
\hline \multicolumn{6}{|c|}{ 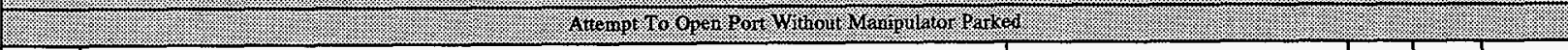 } \\
\hline 47 & $\begin{array}{l}\text { NOTE: The manipulator serves as an interlock for Bagless Transfer Port operation. When the } \\
\text { manipulator is not at the park position, the Bagless Transfer Port should not be able to open. } \\
\text { The manipulator is initially slightly displaced from the park position to allow this interlock to } \\
\text { be tested. } \\
\text { Place the LLW RWM Waste Manipuiator (107-EM-07-201) approximately one foot from park position } \\
2 \text { (farthest from Bagless Transfer Port (107-DO-07-201) with both manipulator arms fully parked. }\end{array}$ & $\begin{array}{l}\text { Visually verify that the waste } \\
\text { manipulator is approximately one } \\
\text { foot away park position } 2 \text { with both } \\
\text { arms parked. }\end{array}$ & $\checkmark$ & & \\
\hline 48 & $\begin{array}{l}\text { Press the "OPEN PORT" button from the "PORT DO-07-201 MENU" at OIU-12-105B to attempt to } \\
\text { open the port. } \\
\text { Because the manipulator is not parked, the port door should not open. }\end{array}$ & $\begin{array}{l}\text { Verify that the Bagless Transfer Port } \\
\text { does not open. }\end{array}$ & $\checkmark$ & & \\
\hline 49 & $\begin{array}{l}\text { Place the LLW RWM Waste Manipulator (107-EM-07-201) at park position } 2 \text { (farthest from Bagless } \\
\text { Transfer Port (107-D0-07-201) with both manipulator arms fully parked. }\end{array}$ & $\begin{array}{l}\text { Visually verify that the waste } \\
\text { manipulator is at park position } 2 \text { with } \\
\text { both arms parked. }\end{array}$ & $V$ & & \\
\hline
\end{tabular}


HNF-SD-W026-ATP-021 Rev. 1

\begin{tabular}{|c|c|c|c|c|c|}
\hline Sep. & 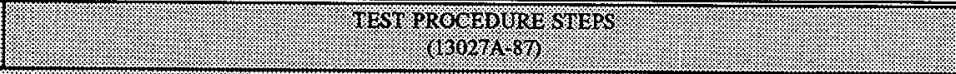 & Expreterourpur & (jaston & (5.11: & (jestivis \\
\hline \multicolumn{6}{|c|}{ 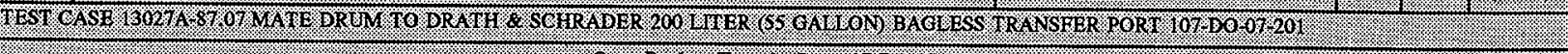 } \\
\hline & 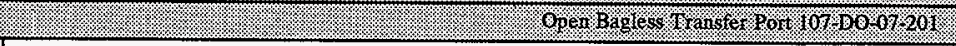 & 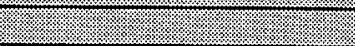 & & & \\
\hline 50 & $\begin{array}{l}\text { Press "OPEN PORT" } \\
\text { The PCS should display a "PORT OPENING..." message at OIU-12-105B while the port is opening. } \\
\text { NOTE: Reaching the weight setpoint and not actuating the lift table overtravel switch should cause the } \\
\text { PCS to give an output (DO-07-201/O) to the Bagless Transfer Port (107-DO-07-201), which } \\
\text { signals the Bagless Transfer Port to open. } \\
\text { The PCS should then display a "OPEN PORT" message at OrU-12-105B. } \\
\text { Record the "Lift Table Weight" and the "Lift Table Weight Setpoint" displayed on the "PORT DO-07- } \\
201 \text { MENU" screen at OIU-12-105B: } \\
\text { Lift Table Weight: } \\
\text { Lift Table Weight Setpoint: } \quad-530 \quad \text { kilograms }\end{array}$ & $\begin{array}{l}\text { Verify that a "OPEN PORT" } \\
\text { message is displayed at OIU-12-105B } \\
\text { after the port is open. } \\
\text { Verify that the weight recorded with } \\
\text { the port open does not fall below the } \\
\text { "Lift Table Weight Setpoint" limit } \\
\text { listed on the "PORT DO-07-201 } \\
\text { MENU" screen. }\end{array}$ & $\checkmark$ & $\checkmark$ & \\
\hline 51 & $\begin{array}{l}\text { Press the "MAIN MENU" button at OIU-12-105B to return to the "LLW RWM GLOVEBOX MAIN } \\
\text { MENU" screen. }\end{array}$ & $\begin{array}{l}\text { Verify that the "LLW RWM } \\
\text { GLOVEBOX MAIN MENU" screen } \\
\text { is displayed at OIU-12-105B. }\end{array}$ & $V$ & & \\
\hline 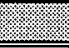 & 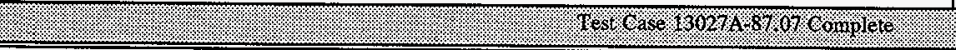 & & & & \\
\hline
\end{tabular}


HNF-SD-W026-ATR-021 Rev. 1

\begin{tabular}{|c|c|c|c|c|c|}
\hline Step & SESPROQEDURB STEPS & 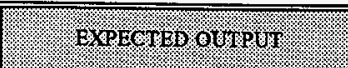 & Pass: & Fail & 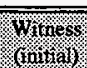 \\
\hline \multicolumn{6}{|c|}{ 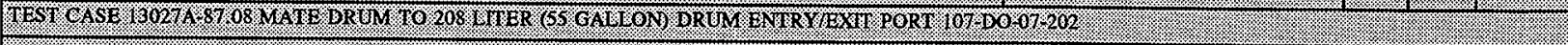 } \\
\hline \multicolumn{6}{|c|}{ r. } \\
\hline 1 & $\begin{array}{l}\text { Activate the lift table "RAISE" and "LOWER" pushbuttons at the lift table local control pedestal (107- } \\
\text { PC-09-201E) to attempt to raise and lower the lift table. } \\
\text { Because the "AGV/PANEL" switch is turned to the "AGV" position, the lift table should not raise or } \\
\text { lower. }\end{array}$ & $\begin{array}{l}\text { Verify that activating the "RAISE" } \\
\text { and "LOWER" pushbuttons has no } \\
\text { effect on the lift table. }\end{array}$ & & & \\
\hline 2 & $\begin{array}{l}\text { Activate the lift table "FORWARD" and "REVERSE" pushbuttons at the lift table local control } \\
\text { pedestal (107-PC-09-201E) to attempt to activate the lift table roller conveyor. } \\
\text { Because the "AGV/PANEL" switch is turned to the "AGV" position, the lift table roller conveyor } \\
\text { should not activate. }\end{array}$ & $\begin{array}{l}\text { Verify that activating the } \\
\text { "FORWARD" and "REVERSE" } \\
\text { pushbuttons has no effect on the lift } \\
\text { table. }\end{array}$ & $V$ & & \\
\hline 3 & $\begin{array}{l}\text { Set the Lift Table Local Control Pedestal AGV/PANEL switch (09-HS-229D) to "PANEL" to allow an } \\
\text { operator to activate and control (via the PCS) the lift table (107-LT-09-201E). }\end{array}$ & $\begin{array}{l}\text { Verify that the lift table } \\
\text { AGV/PANEL switch is switched to } \\
\text { the "PANEL" position (to allow } \\
\text { operator to control the lift table from } \\
\text { the "PANEL"). }\end{array}$ & & & \\
\hline
\end{tabular}


HNF-SD-W026-ATR-021 Rev. 1

\begin{tabular}{|c|c|c|c|c|c|}
\hline She & TEST PRQGEDURE SEIEPS & 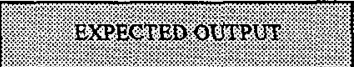 & Pros. & 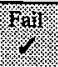 & (ininives) \\
\hline \multicolumn{6}{|c|}{ 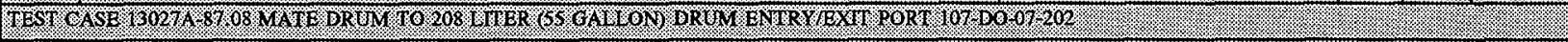 } \\
\hline \multicolumn{6}{|c|}{ IV) } \\
\hline 4 & $\begin{array}{l}\text { Press the "PORT DO-07-202 MENU" button from the "LLW RWM GLOVEBOX MAIN MENU" } \\
\text { screen at OIU-12-105B. } \\
\text { NOTE: The selection of this menu should cause the PCS to check the status of position switch 09-ZS- } \\
229 \mathrm{E} \text { to determine if an empty drum is present at the AGV end of the lift table and check the } \\
\text { status of position switch } 09-\mathrm{ZS}-229 \mathrm{G} \text { to determine if the lift table is at AGV height. } \\
\text { Because the lift table is not at AGV height and no drum is present, OIU-12-105B should display a "NO } \\
\text { DRUM AT LIFT TABLE" message. } \\
\text { Status Bit. N31:94/12 }\end{array}$ & $\begin{array}{l}\text { Verify that OIU-12-105B displays the } \\
\text { "NO DRUM AT LIFT TABLE" } \\
\text { message. }\end{array}$ & 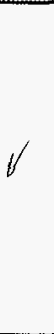 & & \\
\hline 5 & $\begin{array}{l}\text { Press the "OPEN PORT" button from the "PORT DO-07-202 MENU" at OIU-12-105B. } \\
\text { Because a drum is not mated to the port, the port should not open. }\end{array}$ & $\begin{array}{l}\text { Verify that port 107-D0-07-202 does } \\
\text { not open. }\end{array}$ & $\checkmark$ & & \\
\hline & 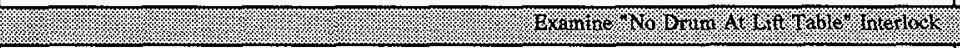 & & & & \\
\hline 6 & $\begin{array}{l}\text { Confirm that the Entry/Exit Port (107-DO-07-202) door is in a horizontal position covering the port. } \\
\text { If the port door is rotated up, energize solenoid 07-FEV-910K/C (Close) to move the port door to its } \\
\text { horizontal position. }\end{array}$ & $\begin{array}{l}\text { Visualiy verify that port door is in a } \\
\text { horizontal position covering the port. }\end{array}$ & $\checkmark$ & & \\
\hline 7 & $\begin{array}{l}\text { Confirm that the port door is closed. If the port door is not closed, energize solenoid 07-FBV-9100/C } \\
\text { (Close) to close the port door. }\end{array}$ & $\begin{array}{l}\text { Visually verify that port door is } \\
\text { lowered to its closed position. }\end{array}$ & $\nu$ & & $K \eta_{2}$ \\
\hline 8 & $\begin{array}{l}\text { Confirm that the port door is locked. If the port door is not locked, energize solenoid } 07-\mathrm{FEV}-910 \mathrm{~J} / \mathrm{L} \\
\text { (Lock) to fully extend locking cylinders to lock port door. }\end{array}$ & $\begin{array}{l}\text { Visually verify that port door is } \\
\text { locked. }\end{array}$ & $\checkmark$ & & $5 \not 2$ \\
\hline 9 & $\begin{array}{l}\text { Confirm that vacuum is not present in the Drum Lid Vacuum System (for Drum Entry/Exit Port 107- } \\
\text { DO-07-202). } \\
\text { If vacuum exists in the system, de-energize the vacuum generation solenoid valve 07-FEV-910I (No } \\
\text { vacuum) and briefly energize the vacuum isolation solenoid 07-FEV-910G to telease any residual } \\
\text { vacuum. Pressure switch 07-PS-900 should not be activated, indicating that vacuum is got present. }\end{array}$ & $\begin{array}{l}\text { Verify that pressure switch 07-PS- } \\
900 \text { is not activated. }\end{array}$ & $V^{\prime}$ & & \\
\hline
\end{tabular}


HNF-SD-W026-ATR-021 Rev. 1

\begin{tabular}{|c|c|c|c|c|c|}
\hline Sies? & TEST PR ROFDURE RTEPS & 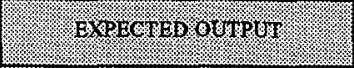 & (3. & Faril & Winess: \\
\hline \multicolumn{6}{|c|}{ 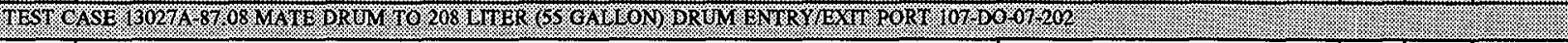 } \\
\hline 10 & Confirm that the HVAC Centering Device for Drum Entry/Exit Port 107-DO-07-202 is retracted. & $\begin{array}{l}\text { Visually verify that the HVAC } \\
\text { Centering Device for Drum } \\
\text { Entry/Exit Port 107-D0-07-202 is } \\
\text { retracted. }\end{array}$ & $\sqrt{2}$ & & \\
\hline 11 & $\begin{array}{l}\text { NOTE: The Entry/Exit Port Lift Table, (107-LT-09-201E) should have been placed in its fully } \\
\text { lowered position during test setup. } \\
\text { Place the } 208 \text { liter ( } 55 \text { gallon) waste drum without band clamp on the LLW RWM } 208 \text { liter ( } 55 \text { gallon) } \\
\text { Entry/Exit Port Lift Table, (107-LT-09-201E). The drum should be placed at the AGV end of the lift } \\
\text { table. } \\
\text { The "AGV END" indicator (09-ZL-229A) on the Lift Table Control Pedestal (107-PC-09-201E) should } \\
\text { be illuminated, indicating that a drum is positioned at the AGV end of the lift table. }\end{array}$ & $\begin{array}{l}\text { Verify that the drum without band } \\
\text { clamp has been placed on the LLW } \\
\text { RWM Glovebox } 208 \text { liter ( } 55 \text { gallon) } \\
\text { Exit Port lift table. } \\
\text { Verify that the "AGV END" } \\
\text { indicator (09-ZL-229A) is } \\
\text { illuminated. }\end{array}$ & $\checkmark$ & & \\
\hline 12 & $\begin{array}{l}\text { Examine the "PORT DO-07-202 MENU" screen at OIU-12-105B. } \\
\text { NOTE: The PCS should continue to check the status of the "Drum at end of Conveyor" position } \\
\text { switch ( } 09-\mathrm{ZS}-229 \mathrm{E}) \text { to determine if an empty drum is present at the AGV end of the lift } \\
\text { table and check the status of the "AGV Mating Height" position switch (09-ZS-229G) to } \\
\text { determine if the lift table is at AGV height. } \\
\text { Because a drum is present but the lift table is not at AGV height, OIU-12-105B should display a "NO } \\
\text { DRUM AT LIFT TABLE" message. }\end{array}$ & $\begin{array}{l}\text { Verify that OIU-12-105B displays the } \\
\text { "NO DRUM AT LIFT TABLE" } \\
\text { message. }\end{array}$ & 2 & & \\
\hline 13 & $\begin{array}{l}\text { Activate the lift table "RAISE" pushbutton at the lift table local control pedestal (107-PC-09-201E) to } \\
\text { raise the lift table to AGV Height. } \\
\text { The lift table at "AGV Height" indicator (09-ZL-229E) on the Lift Table Control Pedestal (107-PC-09- } \\
\text { 201E) should be illuminated, indicating that the lift table is at AGV height. }\end{array}$ & $\begin{array}{l}\text { Visually Verify that the LLW } \\
\text { Process Entry Glovebox Lift Table is } \\
\text { at AGV height. } \\
\text { Verify that the lift table "AGV } \\
\text { Heigh" indicator (09-ZL-229E) is } \\
\text { illuminated. }\end{array}$ & $\checkmark$ & & \\
\hline
\end{tabular}


HNF-SD-W026-ATR-021 Rev. 1

\begin{tabular}{|c|c|c|c|c|c|}
\hline Sep & 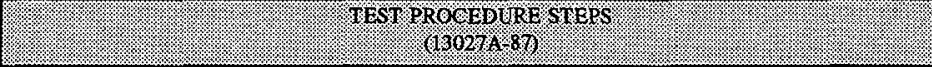 & BXPFCTHBOUYPOY & The & Wait & 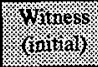 \\
\hline \multicolumn{6}{|c|}{ 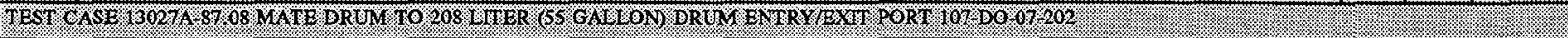 } \\
\hline 14 & $\begin{array}{l}\text { Examine the "PORT DO-07-202 MENU" sereen at OIU-12-105B. } \\
\text { Force Status Bit } N 31: 94 / / 2 \\
\text { Because a drum is present and the lift table is at AGV height, OIU-12-105B should display a "DRUM } \\
\text { AT LIFT TABLE" message. }\end{array}$ & $\begin{array}{l}\text { Verify that OIU-12-105B displays the } \\
\text { "DRUM AT LIFT TABLE" } \\
\text { message. }\end{array}$ & $\checkmark$ & & $k g$ \\
\hline
\end{tabular}


HNF-SD-W026-ATR-021 Rev. 1

\begin{tabular}{|c|c|c|c|c|c|}
\hline Step & 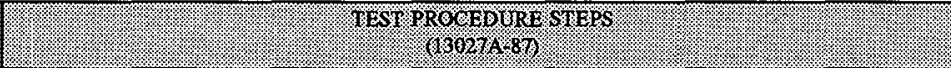 & BXPECTES OUYY & rass & (8ail. & (rinitivily \\
\hline \multicolumn{6}{|c|}{ 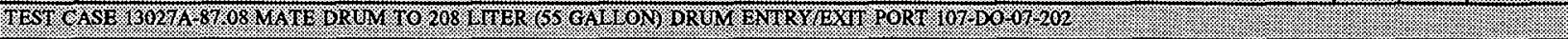 } \\
\hline 策的 & 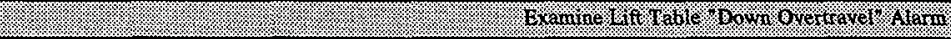 & & & & \\
\hline 15 & $\begin{array}{l}\text { Manually activate the "Down Overtravel" position switch }(09-\mathrm{ZS}-229 \mathrm{C}) \text { to simulate that lift table (107- } \\
\text { LT-09-201E) has been lowered below its normal travel height. } \\
\text { The "DOWN OVERTRAVEL" status indicator (09-ZL-229C) at the Lift Table Local Control Pedestal } \\
\text { (107-PC-09-201E) should be illuminated, indicating that the "Down Overtravel" position switch (09- } \\
\text { ZS-229C) has been activated. }\end{array}$ & $\begin{array}{l}\text { Verify that the "Down Overtravel" } \\
\text { position switch (09-ZS-229C) is } \\
\text { briefly activated. } \\
\text { Verify that the "DOWN } \\
\text { OVERTRAVEL" indicator (09-ZL- } \\
229 C) \text { is illuminated. }\end{array}$ & & & \\
\hline 16 & $\begin{array}{l}\text { Activate the lift table "LOWER" pushbuttons at the lift table local control pedestal (107-PC-09-201E) } \\
\text { to attempt energize lift table motor 107-LT-09-201E/M1. } \\
\text { Because the lift table overtravel switch is activated, the lift table should not lower. }\end{array}$ & $\begin{array}{l}\text { Verify that the lift table does not } \\
\text { lower. }\end{array}$ & $\checkmark$ & & \\
\hline 17 & $\begin{array}{l}\text { Review the "PORT DO-07-202 MENU" status. A flashing "SEQUENCE FAIIED" message should } \\
\text { be displayed and the "ALARMS" button should be flashing. } \\
\text { Press the "ALARMS" button. The "LOCAL ALARMS" screen should be displayed, with a flashing } \\
\text { "Lift Table (201E) Down Overtravel" alarm. } \\
\text { Press the "LOCAL ALARMS" screen to display the "LOCAL ALARMS" screen. Buttons should be } \\
\text { displayed near the bottom of the screen to allow alarms to be acknowledged. An active "Lift Table } \\
\text { (201E) Down Overtravel" alarm should be displayed on this screen. }\end{array}$ & $\begin{array}{l}\text { Verify that a flashing "SEQUENCE } \\
\text { FAILED" message is displayed and } \\
\text { the "ALARMS" button is flashing. } \\
\text { Verify that the "LOCAL ALARMS" } \\
\text { screen is displayed with the active } \\
\text { alarm flashing. } \\
\text { Verify that the "LOCAL ALARMS" } \\
\text { screen with an active "Lift Table } \\
\text { (201E) Down Overtravel" alarm is } \\
\text { displayed. }\end{array}$ & $V$ & & \\
\hline
\end{tabular}


HNF-SD-W026-ATR-021 Rev. 1

\begin{tabular}{|c|c|c|c|c|c|}
\hline Step & 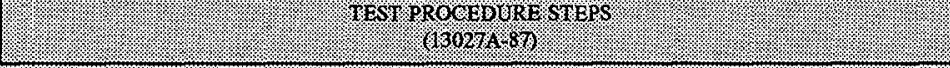 & PXPECTEB OUTPEM & Pros:- & Tart. & Wintitial \\
\hline \multicolumn{6}{|c|}{ 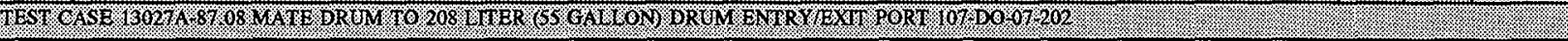 } \\
\hline 18 & $\begin{array}{l}\text { Press the bottom area of the "LOCAL. ALARMS" screen to activate the alarm selector feature. The } \\
\text { currently selected alarm should be highlighted. Press the up and down arrow buttons as needed to } \\
\text { select the appropriate alarm. } \\
\text { Press the "ACK" button to acknowledge the selected alarm. } \\
\text { Press the "DONE" button to return to the "LOCAL ALARMS" screen. }\end{array}$ & $\begin{array}{l}\text { Verify that the appropriate alarm is } \\
\text { selected (highlighted). } \\
\text { Verify that the selected alarm is } \\
\text { acknowledged. } \\
\text { Verify that the "LOCAL ALARMS" } \\
\text { screen is displayed and that the } \\
\text { acknowledged "Lift Table (201E) } \\
\text { Down Overtravel" alarm is } \\
\text { displayed. }\end{array}$ & & & \\
\hline 19 & $\begin{array}{l}\text { Manually reset the "Down Overtravel" position switch (09-ZS-229C) to indicate that the lift table (107- } \\
\text { LT-09-201E) is positioned within its normal vertical travel range. } \\
\text { Resetting the "Down Overtravel" position switch (09-ZS-229C) should cause the "Lift Table (201E) } \\
\text { Down Overtravel" alarm to clear. } \\
\text { The "DOWN OVERTRAVBL" status indicator (09-ZL-229C) at the Lift Table Local Control Pedestal } \\
\text { (107-PC-09-201F) should not be illuminated, indicating that the "Down Overtravel" position switch } \\
(09-Z S-229 \mathrm{C}) \text { is not activated. }\end{array}$ & $\begin{array}{l}\text { Verify that the steady yellow alarm } \\
\text { message haschangetto green- } \\
\text { Cleored. } \\
\text { Verify that the "Lift Table (201B) } \\
\text { Down Overtravel" alarm is clear. } \\
\text { Verify that the "DOWN } \\
\text { OVERTRAVEL" status indicator } \\
\text { (09-ZL-229C) is not illuminated. }\end{array}$ & $\checkmark$ & & \\
\hline 20 & Press the "RETURN TO CURRENT SCREEN" button to return to the "PORT DO-07-202 MENU". & $\begin{array}{l}\text { Verify that the "PORT DO-07-202 } \\
\text { MENU" is displayed with a "DRUM } \\
\text { AT LIFT TABLE" message. }\end{array}$ & $\checkmark$ & & \\
\hline
\end{tabular}


HNF-SD-W026-ATR-021 Rev. 1

\begin{tabular}{|c|c|c|c|c|c|}
\hline step & TEST PRO GEDUR STERS : & Expecrepourpor & Pas. & E. & (tiviness \\
\hline \multicolumn{6}{|c|}{ 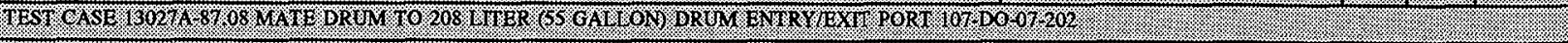 } \\
\hline \multicolumn{6}{|c|}{ 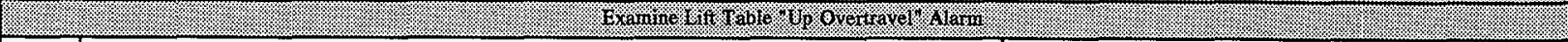 } \\
\hline 21 & $\begin{array}{l}\text { Manually activate the "Up Overtravel" position switch (09-ZS-229D) to simulate that lift table (107- } \\
\text { LT-09-201E) has been raised above its normal travel height. }\end{array}$ & $\begin{array}{l}\text { Verify that "Up Overtravel" position } \\
\text { switch (09-ZS-229D) is activated. }\end{array}$ & 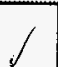 & & \\
\hline 22 & $\begin{array}{l}\text { Review the "PORT DO-07-202 MENU" status. A flashing "SEQUENCE FAILED" message should } \\
\text { be displayed and the "ALARMS" button should be flashing. } \\
\text { Press the "ALARMS" button. The "LOCAL ALARMS" screen should be displayed, with a flashing } \\
\text { "Lift Table 201F Up Overtravel" alarm. } \\
\text { Press the "LOCAL ALARMS" screen to display the "LOCAL ALARMS" screen. Buttons should be } \\
\text { displayed near the bottom of the screen to allow alarms to be acknowledged. An active "Lift Table } \\
\text { 201F Up Overtravel" alarm should be displayed on this screen. }\end{array}$ & $\begin{array}{l}\text { Verify that a flashing "SEQUENCE } \\
\text { FAILED" message is displayed and } \\
\text { the "ALARMS" button is flashing. } \\
\text { Verify that the "LOCAL ALARMS" } \\
\text { screen is displayed with the active } \\
\text { alarm flashing. } \\
\text { Verify that the "LOCAL ALARMS" } \\
\text { screen with an active "Lift Table } \\
201 F \text { Up Overtravel" alarm is } \\
\text { displayed. }\end{array}$ & $\sqrt{ }$ & & \\
\hline 23 & $\begin{array}{l}\text { Press the bottom area of the "LOCAL ALARMS" screen to activate the alarm selector feature. The } \\
\text { currently selected alarm should be highlighted. Press the up and down arrow buttons as needed to } \\
\text { select the appropriate alarm. } \\
\text { Press the "ACK" button to acknowledge the selected alarm. } \\
\text { Press the "DONE" button to return to the "LOCAL ALARMS" screen. }\end{array}$ & $\begin{array}{l}\text { Vexify that the appropriate alarm is } \\
\text { selected (highlighted). } \\
\text { Verify that the selected alarm is } \\
\text { acknowledged. } \\
\text { Verify that the "LOCAL ALARMS" } \\
\text { screen is displayed and that the } \\
\text { acknowledged "Lift Table 201F Up } \\
\text { Overtravel" alarm is displayed on } \\
\text { this screen. }\end{array}$ & $\checkmark$ & & 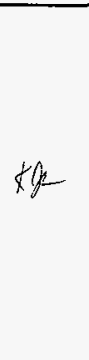 \\
\hline 24 & $\begin{array}{l}\text { Activate the lift table "RAISE" pushbuttons at the lift table local control pedestal (107-PC-09-201E) to } \\
\text { attempt to energize lift table motor 107-LT-09-201E/M1. } \\
\text { Because the lift table overtravel switch is activated, the lift table should not rise. }\end{array}$ & $\begin{array}{l}\text { Verify that the lift table does not } \\
\text { rise. }\end{array}$ & $V$ & & Kle \\
\hline
\end{tabular}


HNF-SD-W026-ATR-021 Rev. 1

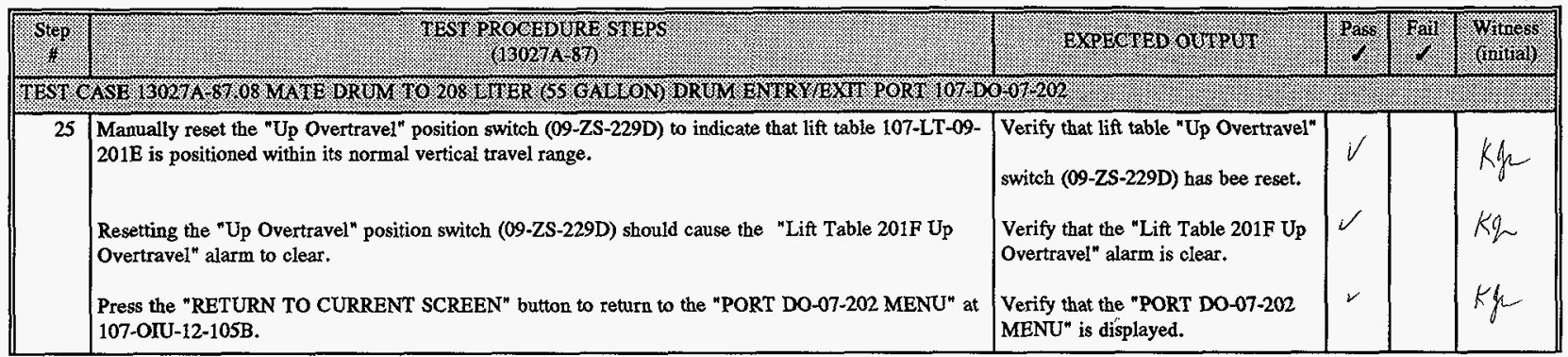


HNF-SD-W026-ATR-021 Rev. 1

\begin{tabular}{|c|c|c|c|c|c|}
\hline Sien: & IEST PROCEDURU SUERS & 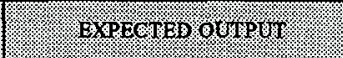 & Pros & (r) & \\
\hline \multicolumn{6}{|c|}{ 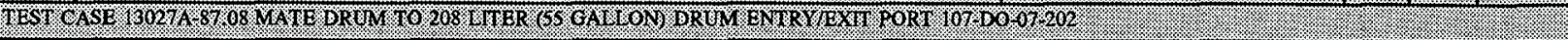 } \\
\hline \multicolumn{6}{|c|}{ 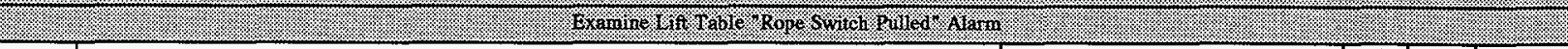 } \\
\hline 26 & $\begin{array}{l}\text { Pull the Lift Table (107-LT-09-201E) Rope Switches to disable all lift table operations. } \\
\text { Press all pushbuttons on the Lift Table Local Control Pedestal (107-PC-09-201E) in both "Normal" } \\
\text { and "Maintenance" modes (Use Lift Table Local Control Pedestal M/O/N switch to switch between } \\
\text { operating modes). Because the rope switches have been pulled, pressing the buttons should have no } \\
\text { effect on the lift table. }\end{array}$ & $\begin{array}{l}\text { Verify that the rope switches have } \\
\text { been pulled. } \\
\text { Verify that pressing the Lift Table } \\
\text { Local Control Pedestal pushbuttons } \\
\text { has no effect on the lift table. }\end{array}$ & 7 & & \\
\hline 27 & $\begin{array}{l}\text { Review the "PORT DO-07-202 MENU" status. A flashing "SEQUENCE FAILED" message should } \\
\text { be displayed and the "ALARMS" button should be flashing. } \\
\text { Press the "ALARMS" button. The "LOCAL ALARMS" screen should be displayed, with a flashing } \\
\text { "Lift Table (201E) Rope Sw. Pulled" alarm. } \\
\text { Press the "LOCAL ALARMS" screen to display the "LOCAL ALARMS" screen. Buttons should be } \\
\text { displayed near the bottom of the screen to allow alarms to be acknowledged. An active "Lift Table } \\
\text { (201B) Rope Sw. Pulled" alarm should be displayed on this screen. }\end{array}$ & $\begin{array}{l}\text { Verify that a flashing "SEQUENCE } \\
\text { FAILED" message is displayed and } \\
\text { the "ALARMS" button is flashing. } \\
\text { Verify that the "LOCAL ALARMS" } \\
\text { screen is displayed with the active } \\
\text { alarm flashing. } \\
\text { Verify that the "LOCAL ALARMS" } \\
\text { screen with an active "Lift Table } \\
\text { (201E) Rope Sw. Pulled" alarm is } \\
\text { displayed. }\end{array}$ & $\checkmark$ & & $\times 0 / 2$ \\
\hline 28 & $\begin{array}{l}\text { Press the bottom area of the "LOCAL ALARMS" screen to activate the alarm selector feature. The } \\
\text { currently selected alarm should be highlighted. Press the up and down arrow buttons as needed to } \\
\text { select the appropriate alarm. } \\
\text { Press the "ACK" button to acknowledge the selected alarm. } \\
\text { Press the "DONE" button to return to the "LOCAL ALARMS" screen. }\end{array}$ & $\begin{array}{l}\text { Verify that the appropriate alarm is } \\
\text { selected (highlighted). } \\
\text { Verify that the selected alarm is } \\
\text { acknowledged. } \\
\text { Verify that the "LOCAL ALARMS" } \\
\text { screen is displayed and that the } \\
\text { acknowledged "Lift Table (201E) } \\
\text { Rope Sw. Pulled" alarm is displayed } \\
\text { on this screen. }\end{array}$ & $V$ & & kon \\
\hline
\end{tabular}




\begin{tabular}{|c|c|c|c|c|c|}
\hline fy & & $\Lambda$ & 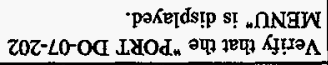 & 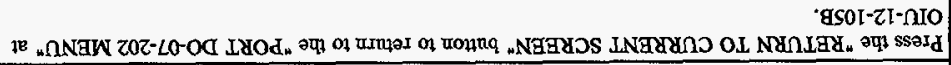 & $0 \varepsilon$ \\
\hline Ni) & & $\gamma$ & 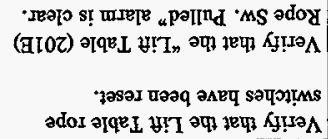 & 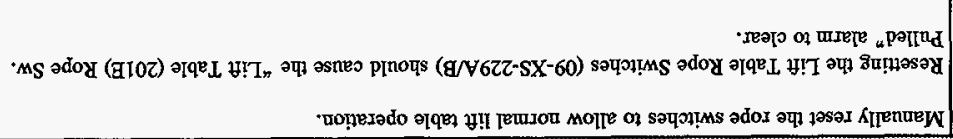 & 62 \\
\hline & & & $202 \div 20$ & 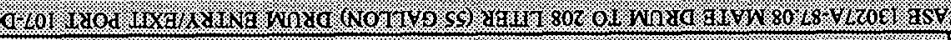 & Sigl \\
\hline 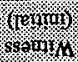 & (xing & s.t. & magrogrog & 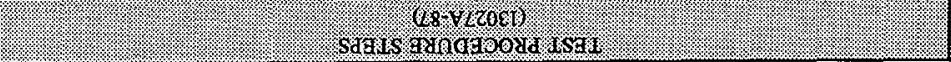 & dis. \\
\hline
\end{tabular}


IINF-SD-W026-ATR-021 Rev. 1

\begin{tabular}{|c|c|c|c|c|c|}
\hline Ster & TEST PROCEDURP STEPS & 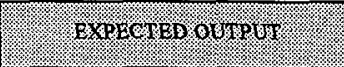 & Sast. & 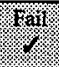 & \\
\hline \multicolumn{6}{|c|}{ 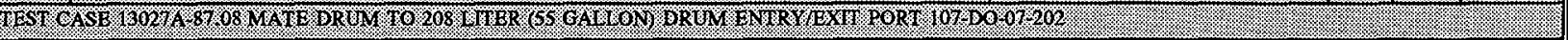 } \\
\hline \multicolumn{6}{|c|}{ 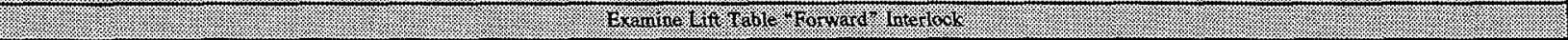 } \\
\hline \multirow[t]{2}{*}{31} & $\begin{array}{l}\text { Activate the "FORWARD" pushbutton at the lift table local control pedestal (107-PC-09-201E) to } \\
\text { energize the lift table conveyor motor forward (107-LT-09-201E/M2). }\end{array}$ & $\begin{array}{l}\text { Verify that activating the } \\
\text { "FORWARD" pushbutton has no } \\
\text { effect on the lift table. }\end{array}$ & & & \multirow{2}{*}{$\begin{array}{l}\text { Kok } \\
9 / 18 \% 7\end{array}$} \\
\hline & 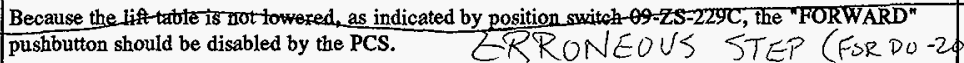 & 2) $A \times 1109^{3}$ & & & \\
\hline 32 & At lift table control pedestal 107-PC-09-201E place the "M/O/N" switch to "NORMAL" & $\begin{array}{l}\text { Verify "M/O/N" switch is set to } \\
\text { "NORMAL". }\end{array}$ & $\zeta$ & & \\
\hline \multirow[t]{2}{*}{33} & Force AGV End of Conveyor Bit "ON". & Verify AGV End of Conveyor Bit & & & \multirow{2}{*}{ - $199 / 189$} \\
\hline & ERKONEOU, SIEP (FOR DO LOL) & "ON". & & & \\
\hline \multirow[t]{3}{*}{$\overline{34}$} & $\begin{array}{l}\text { Activate the lift table "LOWER" pushbutton at the lift table local control pedestal (107-PC-09-201E) as } \\
\text { needed to lower the lift table to its lowered position below AGV height. }\end{array}$ & $\begin{array}{l}\text { Visually confirm that the lift table is } \\
\text { lowered below AGV height. }\end{array}$ & & & \multirow{3}{*}{$\begin{array}{l}\text { k/8/8, } \\
k \text { kg }\end{array}$} \\
\hline & $\begin{array}{l}\text { The "DOWN OVERTRAVEL" indicator at the Lift Table Eocal Control Pedestal 09-ZL-229C_should } \\
\text { not be illuminated, indicating that the tift tabte has not exceeded its lower travel limit. }\end{array}$ & Verify that the " & & & \\
\hline & ERRONEOUS STEP (FCR PO-202) & $\begin{array}{l}\text { OVERTRAVEL" indicator (09-ZL } \\
229 \mathrm{C}) \text { is not illuminated. }\end{array}$ & & & \\
\hline 35 & $\begin{array}{l}\text { Activate the "REVERSE" pushbutton at the Lift Table Local Control Pedestal (107-PC-09-201E) to } \\
\text { energize the lift table conveyor motor reverse (107-LT-09-201E/M2). } \\
\text { The lift table conveyor motor should de-energize when the drum breaks the light beam at the AGV KS } \\
\text { end. }\end{array}$ & $\begin{array}{l}\text { Verify that the conveyor motor de- } \\
\text { energizes. } \\
410109\end{array}$ & $V$ & & \\
\hline
\end{tabular}


HNF-SD-W026-ATR-021 Rev. 1

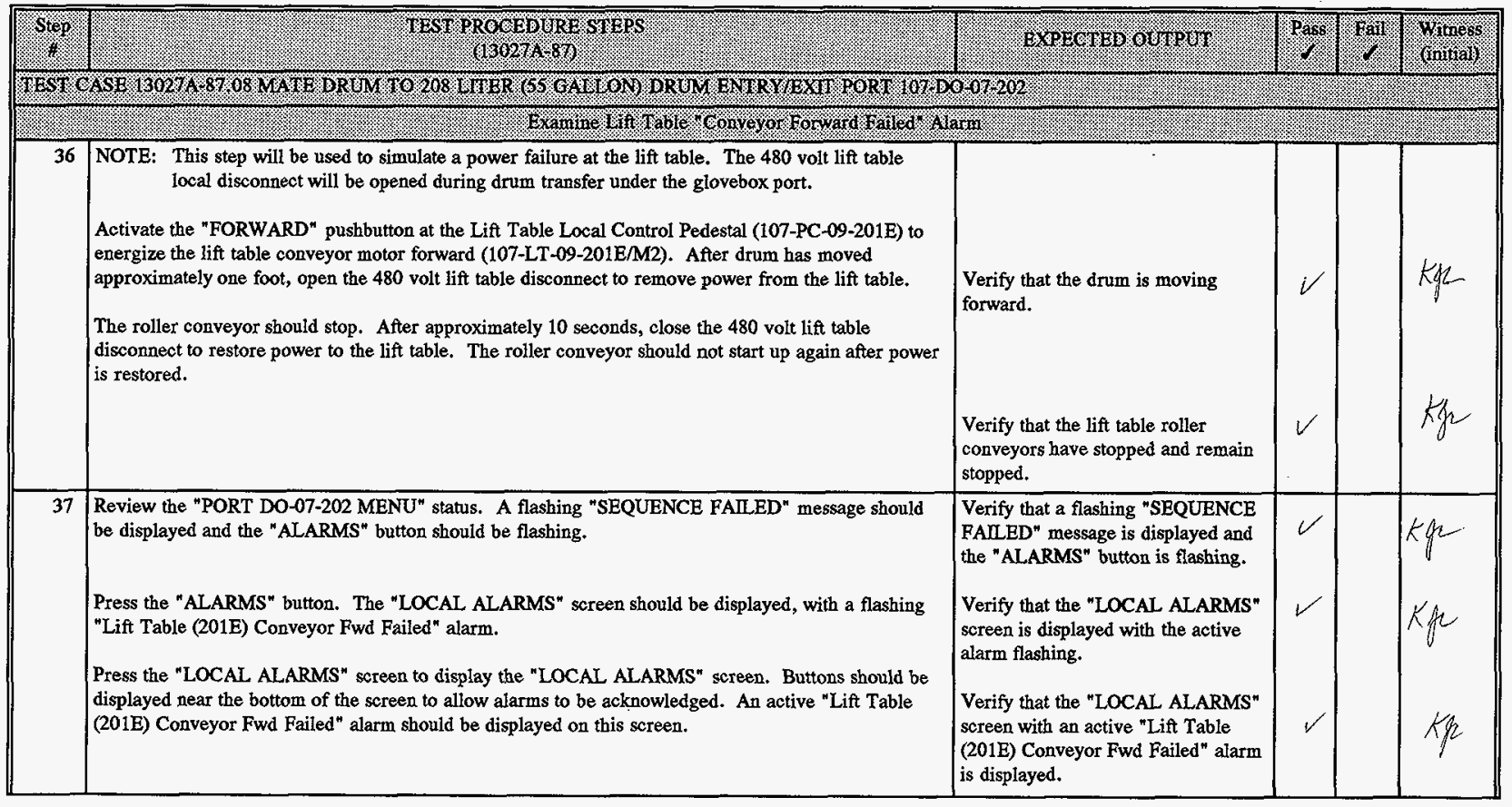


HNF-SD-W026-ATR-021 Rev. 1

\begin{tabular}{|c|c|c|c|c|c|}
\hline Sters. & TEST PROQEDTRE STIEPS & 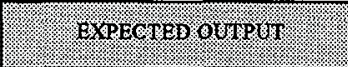 & Pass. & 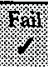 & (8) \\
\hline \multicolumn{6}{|c|}{ 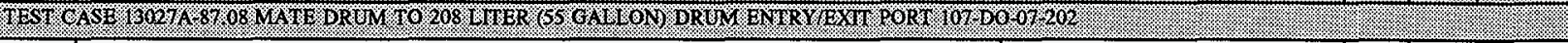 } \\
\hline 38 & $\begin{array}{l}\text { Press the bottom area of the "LOCAL ALARMS" screen to activate the alarm selector feature. The } \\
\text { currently selected alarm should be highlighted. Press the up and down arrow buttons as needed to } \\
\text { select the appropriate alarm. } \\
\text { Press the "ACK" button to acknowledge the selected alarm. } \\
\text { Press the "DONE" button to return to the "LOCAL ALARMS" screen. }\end{array}$ & $\begin{array}{l}\text { Verify that the appropriate alarm is } \\
\text { selected (highlighted). } \\
\text { Verify that the selected alarm is } \\
\text { acknowledged. } \\
\text { Verify that the "LOCAL ALARMS" } \\
\text { screen is displayed and that the } \\
\text { acknowledged "Lift Table (201E) } \\
\text { Conveyor Fwd Failed" alarm is } \\
\text { displayed on this screen. }\end{array}$ & $\checkmark$ & & $k g$ \\
\hline 39 & $\begin{array}{l}\text { Press the "RETURN TO CURRENT SCREEN" button to return to the "PORT DO-07-202 MENU" at } \\
\text { 107-OIU-12-105B. }\end{array}$ & $\begin{array}{l}\text { Verify that the "PORT DO-07-202 } \\
\text { MENU" is displayed and the screen } \\
\text { status displays "SEQUENCE } \\
\text { FAILED". }\end{array}$ & $v$ & & $\mathrm{Kg}$ \\
\hline
\end{tabular}




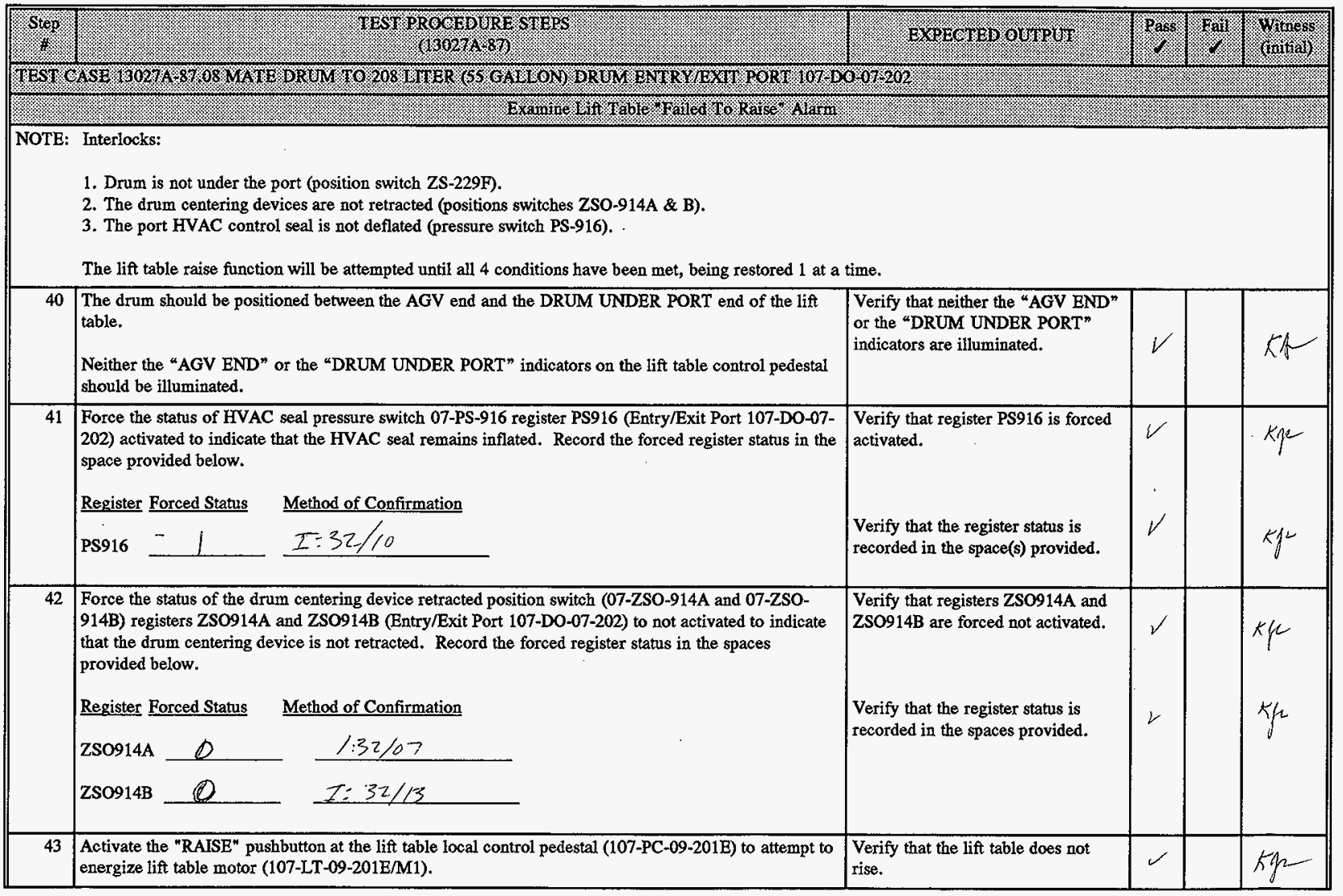


HNF-SD-W026-ATR-021 . Rev. 1

\begin{tabular}{|c|c|c|c|c|c|}
\hline Sien: & (1) & 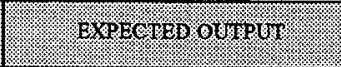 & 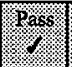 & Ifair. & (rinitivil. \\
\hline \multicolumn{6}{|c|}{ 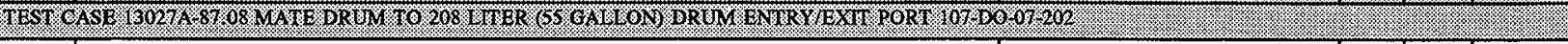 } \\
\hline 44 & $\begin{array}{l}\text { Activate the "FORWARD" pushbutton at the lift table local control pedestal (107-PC-09-201E) to } \\
\text { energize the lift table conveyor motor forward (107-LT-09-201E/M2). The PCS should de-energize } \\
\text { the motor when the drum is centered the Entry/Exit Port (107-DO-07-202). } \\
\text { The "DRUM UNDER PORT" Status indicator (09-ZS-229B) at the Lift Table Local Control Pedestal } \\
\text { should be illuminated, indicating that the drum is centered under the port. }\end{array}$ & $\begin{array}{l}\text { Verify that the drum is centered } \\
\text { under the Entry/Exit Port. } \\
\text { Verify that the DRUM UNDER } \\
\text { PORT" Status indicator (09-ZS- } \\
\text { 229B) is illuminated. }\end{array}$ & $\checkmark$ & & \\
\hline 45 & $\begin{array}{l}\text { Activate the "RAISE" pushbutton at the lift table local control pedestal (107-PC-09-201E) to attempt to } \\
\text { energize lift table motor (107-LT-09-201E/M1). }\end{array}$ & $\begin{array}{l}\text { Verify that the lift table does not } \\
\text { rise. }\end{array}$ & $V$ & & \\
\hline \multirow[t]{2}{*}{46} & $\begin{array}{l}\text { Unforce the status of the HVAC seal pressure switch 07-PS-916 register PS916 (Entry/Exit Port } 107- \\
\text { DO-07-202) to allow this switch to indicate that the HVAC seal is deflated. Record the unforced } \\
\text { register status in the space provided below. }\end{array}$ & $\begin{array}{l}\text { Verify that register PS916 is } \\
\text { unforced. }\end{array}$ & $\checkmark$ & & \\
\hline & Unforced PS916 Register Status: $I: 32 / 10$ & $\begin{array}{l}\text { Verify that the register status is } \\
\text { recorded in the space provided. }\end{array}$ & $V$ & & \\
\hline 47 & $\begin{array}{l}\text { Activate the "RAISE" pushbutton at the lift table local control pedestal (107-PC-09-201E) to attempt to } \\
\text { energize lift table motor (107-LT-09-201E/M1). }\end{array}$ & $\begin{array}{l}\text { Verify that the lift table does not } \\
\text { rise. }\end{array}$ & $\mathscr{V}$ & & \\
\hline \multirow[t]{3}{*}{48} & \multirow{3}{*}{$\begin{array}{l}\text { Unforce the status of the drum centering device position switch (07-ZSO-914A and 07-ZSO-914B) } \\
\text { registers ZSO914A and ZSO914B (Entry/Exit Port 107-DO-07-202) to allow these switches to indicate } \\
\text { that the drum centering device is retracted. Record the unforced register status in the space provided } \\
\text { below. } \\
\text { Unforced ZSO914A Register Status: } \\
\text { Unforced ZSO914B Register Status: }\end{array}$} & $\begin{array}{l}\text { Verify that registers ZSO914A and } \\
\text { ZSO914B are unforced. }\end{array}$ & $V$ & & \\
\hline & & \multirow[b]{2}{*}{$\begin{array}{l}\text { Verify that the register status is } \\
\text { recorded in the space(s) provided. }\end{array}$} & \multirow[b]{2}{*}{$\checkmark$} & \multirow{2}{*}{\multicolumn{2}{|c|}{$\times 12$}} \\
\hline & & & & & \\
\hline 49 & $\begin{array}{l}\text { Change LT 201E "Failed to Raise" TD from current value to of sec. Record Register Contents. } \\
\text { TD Register: T4:113 Register Contents: } 120\end{array}$ & $\begin{array}{l}\text { Verify LT } 201 \mathrm{E} \text { TD is set to } 5 / \text { sec. } \\
\text { and record register contents. / }\end{array}$ & 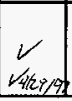 & & r \\
\hline
\end{tabular}


HNF-SD-W026-ATR-021 Rev. 1

\begin{tabular}{|c|c|c|c|c|c|}
\hline Step & TEST TROCEDURE SIEPS & 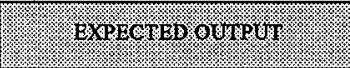 & Pas. & (1) & Winitive \\
\hline \multicolumn{6}{|c|}{ 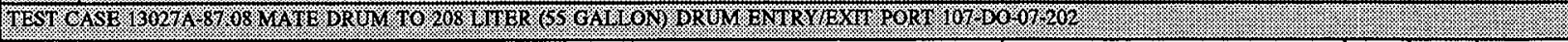 } \\
\hline 50 & $\begin{array}{l}\text { Activate the "RAISE" pushbutton at the lift table local control pedestal (107-PC-09-201E) to energize } \\
\text { the lift table eonveyer-motor (107-LT-09-201E/M1) to raise the lift table. } \\
\text { Because a drum is present under the Entry/Exit Port, as indicated by position switch 09-ZS-229F, the } \\
\text { "RAISE" pushbutton should be enabled by the PCS and the drum should rise to the "Drum Centering" } \\
\text { position. } \\
\text { Record the "Drum Centering" position height in the space provided below: } \\
\text { Drum Centering Height: }\end{array}$ & $\begin{array}{l}\text { Verify that the drum rises to the } \\
\text { "Drum Centering" Position. }\end{array}$ & & & \\
\hline $4 x^{\prime}$ & $\begin{array}{l}\text { Review the "PORT DO-07-202 MENU" status. A flashing "SEQUENCE FAILED" message should } \\
\text { be displayed and the "ALARMS" button should be flashing. } \\
\text { Press the "ALARMS" button. The "LOCAL ALARMS" screen should be displayed, with a flashing } \\
\text { "Lift Table (201E) Failed to Raise" alarm. } \\
\text { Press the "LOCAL ALARMS" screen to display the "LOCAL ALARMS" screen. Buttons should be } \\
\text { displayed near the bottom of the screen to allow alarms to be acknowledged. An active "Lift Table } \\
\text { (201E) Failed to Raise" alarm should be displayed on this screen. }\end{array}$ & $\begin{array}{l}\text { Verify that a flashing "SEQUENCE } \\
\text { FAILED" message is displayed and } \\
\text { the "ALARMS" button is flashing. } \\
\text { Verify that the "LOCAL ALARMS" } \\
\text { screen is displayed with the active } \\
\text { alarm flashing. } \\
\text { Verify that the "ACTIVE ALARMS" } \\
\text { screen with an active "Lift Table } \\
\text { (201E) Failed to Raise" alarm is } \\
\text { displayed. }\end{array}$ & 4hath & & $k n-$ \\
\hline $\begin{array}{r}52 \\
623\end{array}$ & $\begin{array}{l}\text { Press the bottom area of the "LOCAL ALARMS" screen to activate the alarm selector feature. The } \\
\text { currently selected alarm should be highlighted. Press the up and down arrow buttons as needed to } \\
\text { select the appropriate alarm. } \\
\text { Press the "ACK" button to acknowledge the selected alarm. } \\
\text { Press the "DONE" button to return to the "LOCAL ALARMS" screen. }\end{array}$ & $\begin{array}{l}\text { Verify that the selected alarm is } \\
\text { acknowiedged. } \\
\text { Verify that the "LOCAL ALARMS" } \\
\text { screen is displayed and that the } \\
\text { acknowledged "Lift Table (201E) } \\
\text { Failed to Raise" alarm is displayed } \\
\text { on this screen. }\end{array}$ & $42 \pi \mid$ & & $K$ \\
\hline
\end{tabular}


HNF-SD-W026-ATR-021 Rev. 1

\begin{tabular}{|c|c|c|c|c|c|}
\hline Step: & TEST PROCEDUREQTEST & 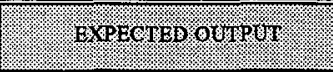 & 19.8. & sar. & (rovitulin: \\
\hline \multicolumn{6}{|c|}{ 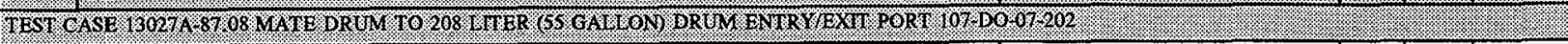 } \\
\hline 65 & $\begin{array}{l}\text { Press the "RETURN TO CURRENT SCREEN" button to return to the "PORT DO-07-202 MENU" at } \\
107-\text { OIU-12-105B. }\end{array}$ & $\begin{array}{l}\text { Verify that the "PORT DO-07-202 } \\
\text { MENU" is displayed. }\end{array}$ & $4|4|$ & & KR \\
\hline $\begin{array}{r}-54 \\
620\end{array}$ & Restore Register $\mathrm{T} 4: 113$ to value recorded in Step 49. & $\begin{array}{l}\text { Verify that Register } T 4: 113 \text { is } \\
\text { set to the correct value. }\end{array}$ & $\checkmark i\left(i^{4}\right.$ & & $K R$ \\
\hline
\end{tabular}


HNF-SD-W026-ATR-021 Rev. 1

\begin{tabular}{|c|c|c|c|c|c|}
\hline Segen & 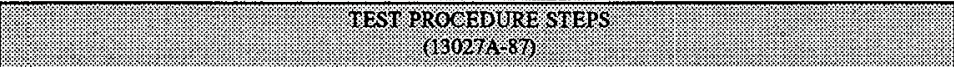 & 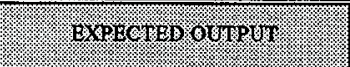 & (1) & 28. & 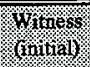 \\
\hline \multicolumn{6}{|c|}{ 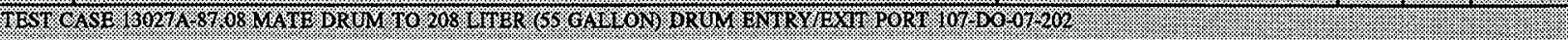 } \\
\hline \multicolumn{6}{|c|}{ 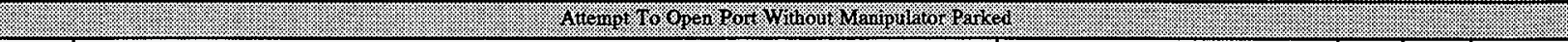 } \\
\hline 55 & $\begin{array}{l}\text { NOTE: The manipulator serves as an interlock for Entry/Exit Port operation. When the manipulator } \\
\text { is not at the park position, the Entry/Exit Port should not be able to open. The manipulator is } \\
\text { initially slightly displaced from the park position to allow this interlock to be tested. } \\
\text { Place the LLW RWM Waste Manipulator (107-EM-07-201) approximately one foot from park position } \\
2 \text { (farthest from Bagless Transfer Port (107-DO-07-201) with both manipulator arms fully parked. }\end{array}$ & $\begin{array}{l}\text { Visually verify that the waste } \\
\text { manipulator is approximately one } \\
\text { foot away park position } 2 \text { with both } \\
\text { arms parked. }\end{array}$ & $\checkmark$ & & \\
\hline 56 & $\begin{array}{l}\text { Press the "OPEN PORT" button from the "PORT DO-07-202 MENU" screen at OIU-12-105B. } \\
\text { Because the manipulator is not parked, the lift table should not raise the drum and the port (107-DO- } \\
07-202 \text { ) should not open. }\end{array}$ & $\begin{array}{l}\text { Verify that the lift table does not } \\
\text { rise. } \\
\text { Verify that the port does not open. }\end{array}$ & $\checkmark$ & & 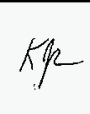 \\
\hline 57 & $\begin{array}{l}\text { Place the LLW RWM Waste Manipulator (107-EM-07-201) at park position } 2 \text { (farthest from Bagless } \\
\text { Transfer Port (107-DO-07-201) with both manipulator arms fully parked. }\end{array}$ & $\begin{array}{l}\text { Visually verify that the waste } \\
\text { manipulator is at park position } 2 \text { with } \\
\text { both arms parked. }\end{array}$ & $\checkmark$ & & $K k$ \\
\hline
\end{tabular}




\begin{tabular}{|c|c|c|c|c|c|}
\hline thy & & $\Lambda$ & 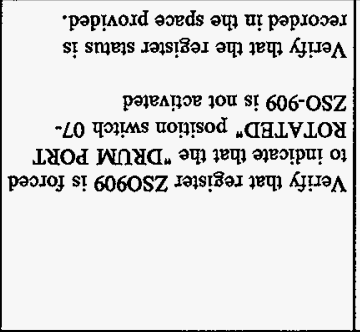 & 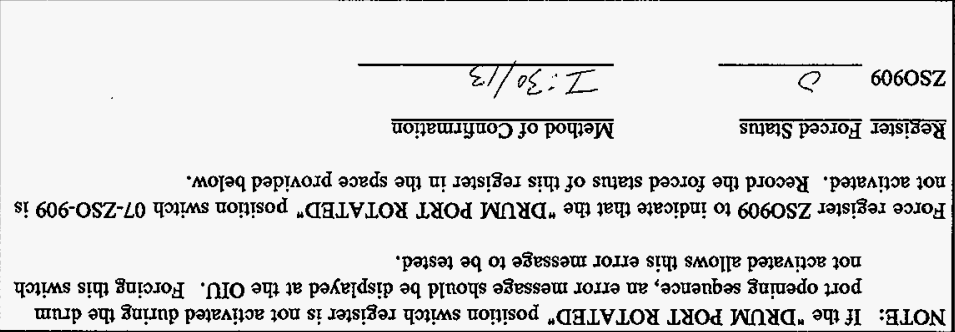 & 09 \\
\hline$-i f y$ & & $n$ & 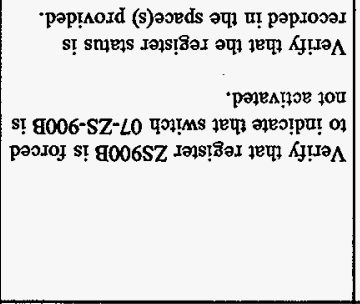 & 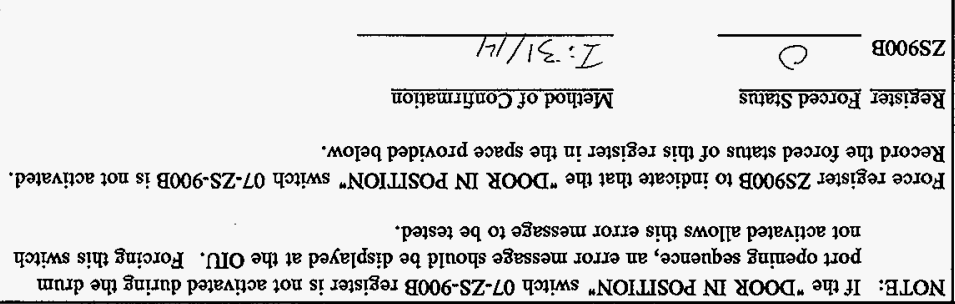 & $6 s$ \\
\hline my & & $\Lambda$ & 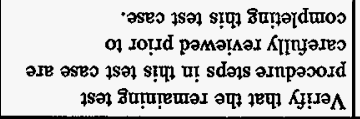 & 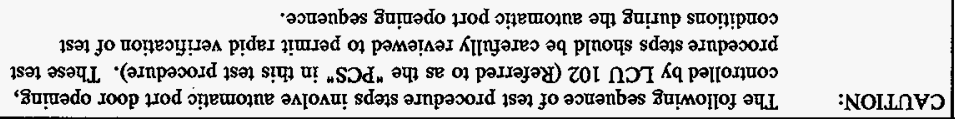 & $8 \mathrm{~S}$ \\
\hline & & & & 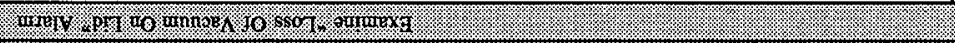 & : \\
\hline & & & (6.2. & 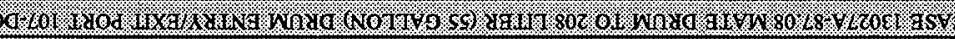 & Orsal \\
\hline (sivinitix & 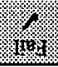 & (ssid: & 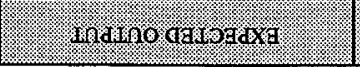 & 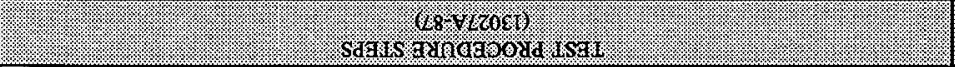 & (2) \\
\hline
\end{tabular}




\begin{tabular}{|c|c|c|c|c|c|}
\hline Step: & 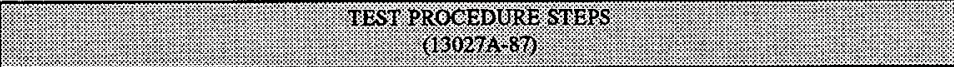 & 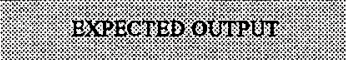 & Pass & Wharit & $\begin{array}{l}\text { Witiness: } \\
\text { (initia) }\end{array}$ \\
\hline \multicolumn{6}{|c|}{ 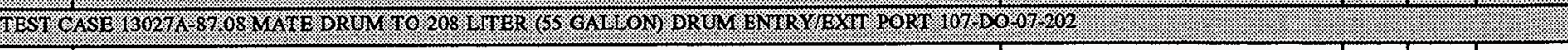 } \\
\hline 61 & $\begin{array}{l}\text { NOTE: If the "SYSTEM ESTABLISHED ADEQUATE VACUUM" pressure switch register is not } \\
\text { activated during the drum port opening sequence, an error message should be displayed at the } \\
\text { OIU. Forcing this switch not activated allows this error message to be tested. } \\
\text { Force register PS900 to indicate that the "SYSTEM ESTABLISHED ADEQUATE VACUUM" } \\
\text { pressure switch 07-PS-900 is not activated. Record the forced status of this register in the space } \\
\text { provided below. } \\
\text { Register Forced Status } \\
\text { PS900 }\end{array}$ & $\begin{array}{l}\text { Verify that register PS900 is forced } \\
\text { to indicate that the "SYSTEM } \\
\text { ESTABLISHED ADEQUATE } \\
\text { VACUUM" pressure switch 07-PS- } \\
900 \text { is not activated. } \\
\text { Verify that the register status is } \\
\text { recorded in the space provided. }\end{array}$ & $V$ & & \\
\hline 62 & $\begin{array}{l}\text { Press the "OPEN PORT" button from the "PORT DO-07-202 MENU" screen at OIU-12-105B. } \\
\text { The PCS should display a "PORT OPENING..." message at OIU-12-105B while the port is opening. } \\
\text { The PCS should automatically energize and hold 07-FEV-324A, activating the centering clamps around } \\
\text { the drum. }\end{array}$ & $\begin{array}{l}\text { Verify that "PORT OPENING..." } \\
\text { message is displayed. } \\
\text { Verify that the drum centering } \\
\text { clamps extend, centering the drum } \\
\text { under the port. }\end{array}$ & $\sqrt{ }$ & & \\
\hline 63 & $\begin{array}{l}\text { The PCS should automatically energize lift table motor (107-LT-09-201E/M1) to slowly raise the lift } \\
\text { table until the drum activates position switch 07-ZS-907, indicating that the drum is in position to begin } \\
\text { the port opening sequence. }\end{array}$ & $\begin{array}{l}\text { Verify that the lift table rises and } \\
\text { then stops. }\end{array}$ & $V$ & & \\
\hline 64 & $\begin{array}{l}\text { The PCS shouid energize and hold solenoid valve 07-FEV-910G. Energizing this isolation valve } \\
\text { allows vacuum to be applied to the drum lid vacuum system. The PCS should then energize solenoid } \\
\text { valve 07-FEV-910IV (Vacuum) creating vacuum at the Drum Entry/Exit Port (107-DO-07-202). } \\
\text { Because pressure switch 07-PS-900 is not activated, the drum port opening sequence should stop. } \\
\text { Wait } 2 \text { minutes to confirm that the HVAC seal does not inflate, indicating that the drum port opening } \\
\text { sequence has stopped. }\end{array}$ & $\begin{array}{l}\text { Verify that the HVAC seal does not } \\
\text { inflate during the } 2 \text { minute time } \\
\text { period, indicating that the drum port } \\
\text { opening sequence has stopped. }\end{array}$ & $\checkmark$ & & \\
\hline
\end{tabular}




\begin{tabular}{|c|c|c|c|c|c|}
\hline Step: & 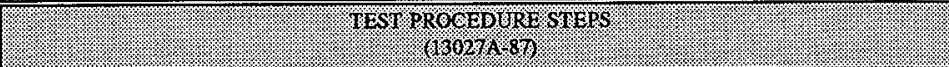 & 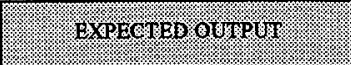 & Pas. & 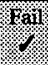 & Winingss \\
\hline \multicolumn{6}{|c|}{ 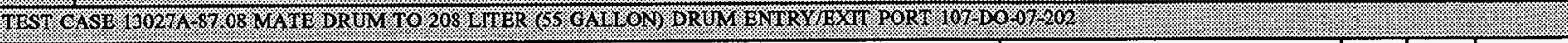 } \\
\hline 65 & $\begin{array}{l}\text { Review the "PORT DO-07-202 MENU" status. A flashing "SEQUENCE FAlLED" message should } \\
\text { be displayed and the "ALARMS" button should be flashing. } \\
\text { Press the "ALARMS" button. The "LOCAL ALARMS" screen should be displayed, with a flashing } \\
\text { "Loss of Vacuum on Lid" alarm. } \\
\text { Press the "LOCAL ALARMS" screen to display the "LOCAL ALARMS" screen. Buttons should be } \\
\text { displayed near the bottom of the screen to allow alarms to be acknowledged. An active "Loss of } \\
\text { Vacuum on Lid" alarm should be displayed on this screen. }\end{array}$ & $\begin{array}{l}\text { Verify that a flashing "SEQUENCE } \\
\text { FAILED" message is displayed and } \\
\text { the "ALARMS" button is flashing. } \\
\text { Verify that the "LOCAL ALARMS" } \\
\text { screen is displayed with the active } \\
\text { alarm flashing. } \\
\text { Verify that the "LOCAL ALARMS" } \\
\text { screen with an active "Loss of } \\
\text { Vacuum on Lid" alarm is displayed. }\end{array}$ & $\checkmark$ & & \\
\hline 66 & $\begin{array}{l}\text { Press the bottom area of the "LOCAL ALARMS" screen to activate the alarm selector feature. The } \\
\text { cuirsently selected alarm should be highlighted. Press the up and down arrow buttons as needed to } \\
\text { select the appropriate alarm. } \\
\text { Press the "ACK" button to acknowledge the selected alarm. } \\
\text { Press the "DONE" button to return to the "LOCAL ALARMS" screen. }\end{array}$ & $\begin{array}{l}\text { Verify that the appropriate alarm is } \\
\text { selected (highlighted). } \\
\text { Verify that the selected alarm is } \\
\text { acknowledged. } \\
\text { Verify that the "LOCAL ALARMS" } \\
\text { screen is displayed and that the } \\
\text { acknowledged "Loss of Vacuum on } \\
\text { Lid" alarm is displayed on this } \\
\text { screen. }\end{array}$ & $\checkmark$ & & \\
\hline 67 & $\begin{array}{l}\text { NOTE: The PCS should continue check the status of pressure switch 07-PS-900. } \\
\text { Unforce register PS900 status to permit pressure switch 07-PS-900 to indicate whether vacuum exists } \\
\text { in the lid vacuum system. Record the unforced register status in the space provided below: } \\
\text { Unforced PS900 Register Status: }\end{array}$ & $\begin{array}{l}\text { Verify that pressure switch 07-PS- } \\
900 \text { indicates vacuum exists between } \\
\text { the port door and the drum lid. } \\
\text { Verify that the register status is } \\
\text { recorded in the space provided. }\end{array}$ & $\checkmark$ & & \\
\hline 68 & $\begin{array}{l}\text { Press the "RETURN TO CURRENT SCREEN" button to return to the "PORT DO-07-202 MENU" at } \\
107-010-12-105 B \text {. }\end{array}$ & $\begin{array}{l}\text { Verify that the "PORT DO-07-202 } \\
\text { MENU" is displayed. }\end{array}$ & $L$ & & \\
\hline
\end{tabular}




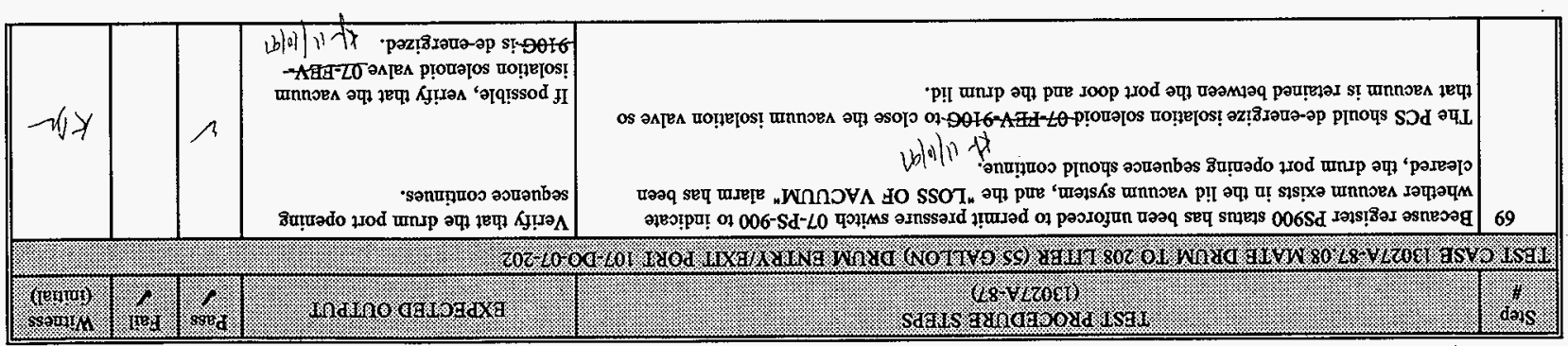

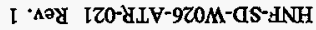


HNF-SD-W026-ATR-021 Rev. 1

\begin{tabular}{|c|c|c|c|c|c|}
\hline (t: & 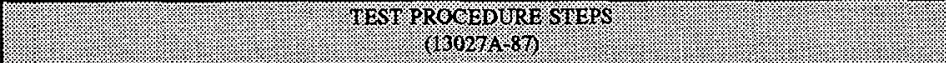 & 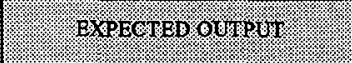 & paso & 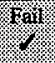 & (initiviling \\
\hline \multicolumn{6}{|c|}{ 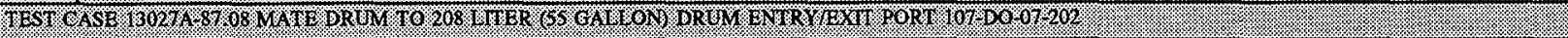 } \\
\hline \multicolumn{6}{|c|}{ \% } \\
\hline 70 & $\begin{array}{l}\text { The PCS should check the status of pressure switch 07-PS-900. If } 07-\mathrm{PS}-900 \text { indicates that adequate } \\
\text { vacuum is present, the PCS should de-energize 07-FEV-910I/V. }\end{array}$ & $\begin{array}{l}\text { If possible, verify that the vacuum } \\
\text { generation solenoid valve } 07-\mathrm{FEV} \text { - } \\
910 \mathrm{I} \text { is de-energized. }\end{array}$ & $\checkmark$ & & \\
\hline 71 & $\begin{array}{l}\text { The PCS should energize solenoid valve 07-FEV-325A to inflate the HVAC Seal for Drum Entry/Exit } \\
\text { Port 107-D0-07-202. }\end{array}$ & $\begin{array}{l}\text { Visually verify that the HVAC Seal } \\
\text { for Drum Entry/Exit Port 107-DO- } \\
\text { 07-202 is inflated. }\end{array}$ & $\nu$ & & \\
\hline 72 & $\begin{array}{l}\text { The PCS should briefly energize solenoid valves } 07-\mathrm{FEV}-913 \mathrm{C} \text { and } 07-\mathrm{FEV}-913 \mathrm{D} \text { (Vent) to release } \\
\text { pressure on the port door open/close cylinders. This allows the cylinders to move freely and should } \\
\text { release any residual pressure on the port door. }\end{array}$ & $\begin{array}{l}\text { If possible, verify that solenoid } \\
\text { valves 07-FEV-913C and 07-FEV- } \\
\text { 913D are briefly energized to release } \\
\text { pressure on the port door open/close } \\
\text { cylinders. }\end{array}$ & $\checkmark$ & & \\
\hline 73 & $\begin{array}{l}\text { The PCS should pulse energize solenoid 07-FEV-910J/UL (Unlock) to fully retract the port door } \\
\text { locking cylinders. }\end{array}$ & $\begin{array}{l}\text { Visually verify that both port door } \\
\text { locking cylinders are fully retracted. }\end{array}$ & 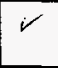 & & \\
\hline 74 & $\begin{array}{l}\text { The PCS should activate the lift table servo motor (107-LT-09-201E/M1) to raise the lift table, drum, } \\
\text { and port door up until the port door is raised to the "DOOR IN POSITION" height. } \\
\text { Because position switch 07-ZS-900B (Door In Position) is forced not activated, the drum port opening } \\
\text { sequence should stop. Wait } 2 \text { minutes to confirm that the port door does not rise to the "Open" } \\
\text { position, indicating that the drum port opening sequence has stopped. }\end{array}$ & $\begin{array}{l}\text { Visually verify that the lift table rises } \\
\text { causing the drum to lift the port door } \\
\text { to the "Door in Position" height. } \\
\text { Verify that the port door does not } \\
\text { rise to the "Open" position during } \\
\text { the } 2 \text { minute time period, indicating } \\
\text { that the drum port opening sequence } \\
\text { has stopped. }\end{array}$ & $V$ & & \\
\hline
\end{tabular}




\begin{tabular}{|c|c|c|c|c|c|}
\hline Ster & 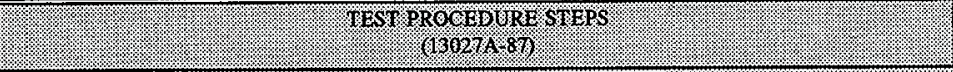 & RXPECTED OOTPUT & Pass. & earlo & (nitival) \\
\hline \multicolumn{6}{|c|}{ 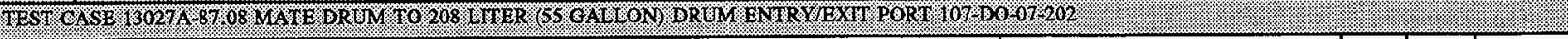 } \\
\hline 75 & $\begin{array}{l}\text { Review the "PORT DO-07-202 MENU" status. A flashing "SEQUENCE FAILED" message should } \\
\text { be displayed and the "ALARMS" button should be flashing. } \\
\text { Press the "ALARMS" button. The "LOCAL ALARMS" screen should be displayed, with a flashing } \\
\text { "DOOR IN POSITION NOT VERIFIED" alarm. } \\
\text { Press the "LOCAL ALARMS" screen to display the "LOCAL ALARMS" screen. Buttons should be } \\
\text { displayed near the bottom of the screen to allow alarms to be acknowledged. An active "DOOR IN } \\
\text { POSITION NOT VERIFIED" alarm should be displayed on this screen. }\end{array}$ & $\begin{array}{l}\text { Verify that a flashing "SEQUENCE } \\
\text { FAILED" message is displayed and } \\
\text { the "ALARMS" button is flashing. } \\
\text { Verify that the "LOCAL ALARMS" } \\
\text { screen is displayed with the active } \\
\text { alarm flashing. } \\
\text { Verify that the "LOCAL ALARMS" } \\
\text { screen with an active "DOOR IN } \\
\text { POSITION NOT VERIFIED" alarm } \\
\text { is displayed. }\end{array}$ & $\checkmark$ & & \\
\hline 76 & $\begin{array}{l}\text { Press the bottom area of the "LOCAL ALARMS" screen to activate the alarm selector feature. The } \\
\text { currently selected alarm should be highlighted. Press the up and down arrow buttons as needed to } \\
\text { select the appropriate alarm. } \\
\text { Press the "ACK" button to acknowledge the selected alarm. } \\
\text { Press the "DONE" button to return to the "LOCAL ALARMS" screen. }\end{array}$ & $\begin{array}{l}\text { Verify that the appropriate alarm is } \\
\text { selected (highlighted). } \\
\text { Verify that the selected alarm is } \\
\text { acknowledged. } \\
\text { Verify that the "LOCAL ALARMS" } \\
\text { screen is displayed and that the } \\
\text { acknowledged "DOOR IN } \\
\text { POSITION NOT VERIFIED" alarm } \\
\text { is displayed on this screen. }\end{array}$ & $\checkmark$ & & \\
\hline 77 & $\begin{array}{l}\text { Unforce register ZS900B status to permit position switch 07-ZS-900B to indicate that the port door is } \\
\text { raised to the "DOOR IN POSITION" height. Record the unforced register status in the space provided } \\
\text { below: } \\
\text { Unforced ZS900B Register Status: } \\
\text { The PCS should continue check the status of position switch } 07-Z S-900 \mathrm{~B} \text {. }\end{array}$ & $\begin{array}{l}\text { Verify that position switch } 07-Z S- \\
900 B \text { indicates that the port door is } \\
\text { raised to the "DOOR IN POSITION" } \\
\text { height } \\
\text { Verify that the register status is } \\
\text { recorded in the space provided. }\end{array}$ & $\checkmark$ & & \\
\hline 78 & $\begin{array}{l}\text { Press the "RETURN TO CURRENT SCREEN" button to return to the "PORT DO-07-202 MENU" at } \\
\text { 107-OIU-12-105B. }\end{array}$ & $\begin{array}{l}\text { Verify that the "PORT DO-07-202 } \\
\text { MENU" is displayed. }\end{array}$ & $V$ & & \\
\hline
\end{tabular}




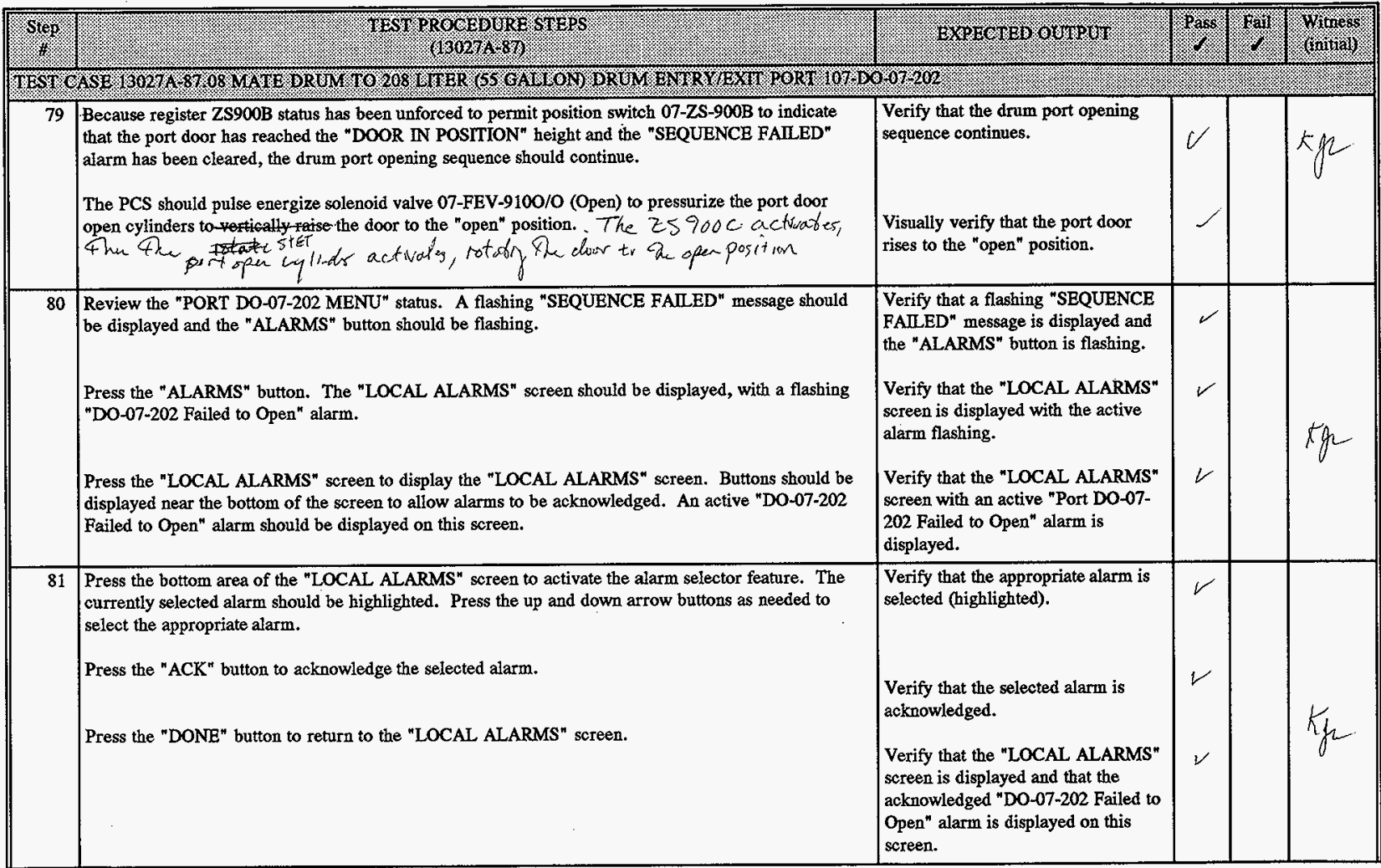


HNF-SD-W026-ATR-021 Rev, 1

\begin{tabular}{|c|c|c|c|c|c|}
\hline Step & 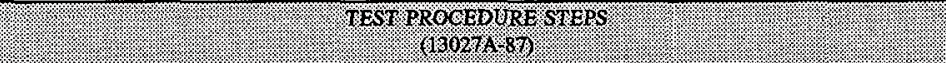 & 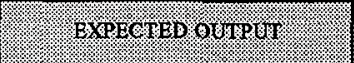 & S\% & \%ail & (xinessing \\
\hline \multicolumn{6}{|c|}{ 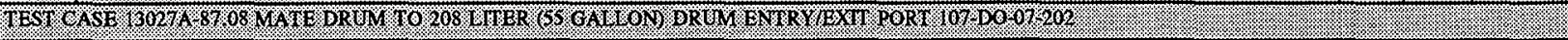 } \\
\hline \multicolumn{6}{|c|}{ V. } \\
\hline 82 & $\begin{array}{l}\text { Press the "RETURN TO CURRENT SCREEN" button to return to the "PORT DO-07-202 MENU" at } \\
\text { 107-OIU-12-105B. }\end{array}$ & $\begin{array}{l}\text { Verify that the "PORT DO-07-202 } \\
\text { MENU" is displayed. }\end{array}$ & & & \\
\hline 83 & $\begin{array}{l}\text { Unforce register ZSO909 status to permit position switch 07-ZSO-909 to indicate that the port door is } \\
\text { rotated open. Record the unforced register status in the space provided below: } \\
\text { Unforced ZSO909 Register Status: } \\
\text { A "PORT OPEN" message should be displayed at OIU-12-10SB. }\end{array}$ & $\begin{array}{l}\text { Verify that the register status is } \\
\text { recorded in the space provided. } \\
\text { Verify that a "PORT OPEN" } \\
\text { message is displayed. }\end{array}$ & $V$ & & \\
\hline 84 & The drum lid should remain attached to the port door. & $\begin{array}{l}\text { Verify that the drum lid remains } \\
\text { attached to the port door. }\end{array}$ & $V$ & & \\
\hline 85 & Press the "MAIN MENU" button at OIU-12-105B to return to the Main Menu. & $\begin{array}{l}\text { Verify that the "LLW RWM } \\
\text { GLOVEBOX MANN MENU" screen } \\
\text { is displayed at OIU-12-105B. }\end{array}$ & $i$ & & \\
\hline & 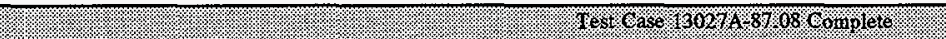 & & & & \\
\hline
\end{tabular}


HINF-SD-W026-ATR-021 Rev. 1

\begin{tabular}{|c|c|c|c|c|c|}
\hline Sol & 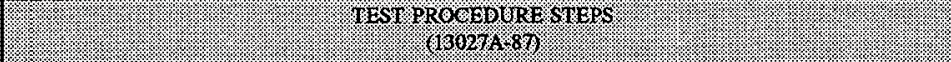 & HXPG $10 \% 0 \%$ & Pass & 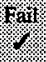 & (initiving \\
\hline \multicolumn{6}{|c|}{ 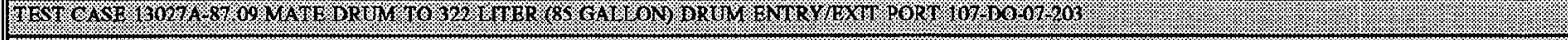 } \\
\hline 1 & $\begin{array}{l}\text { Activate the lift table "RAISE" and "LOWER" pushbuttons at the lift table local control pedestal (107- } \\
\text { PC-09-201D) to attempt to raise and lower the lift table. } \\
\text { Because the "AGV/PANEL" switch is turned to the "AGV" position, the lift table should not raise or } \\
\text { lower. }\end{array}$ & $\begin{array}{l}\text { Verify that activating the "RAISE" } \\
\text { and "LOWER" pushbuttons has no } \\
\text { effect on the lift table. }\end{array}$ & & & \\
\hline 2 & $\begin{array}{l}\text { Activate the lift table "FORWARD" and "REVERSE" pushbuttons at the lift table local control } \\
\text { pedestal (107-PC-09-201D) to attempt to activate the lift table roller conveyor. } \\
\text { Because the "AGV/PANEL" switch is turned to the "AGV" position, the lift table roller conveyor } \\
\text { should not activate. }\end{array}$ & $\begin{array}{l}\text { Verify that activating the } \\
\text { "FORWARD" and "REVERSE" } \\
\text { pushbuttons has no effect on the lift } \\
\text { table. }\end{array}$ & & & \\
\hline 3 & $\begin{array}{l}\text { Set the Lift Table Local Control Pedestal AGV/PANEL switch (09-HS-227D) to "PANEL" to allow an } \\
\text { operator to activate and control (via the PCS) the lift table (107-LT-09-201D). }\end{array}$ & $\begin{array}{l}\text { Verify that the lift table } \\
\text { AGV/PANEL switch is switched to } \\
\text { the "PANEL" position (to allow } \\
\text { operator to control the lift table from } \\
\text { the "PANEL". }\end{array}$ & & & \\
\hline
\end{tabular}




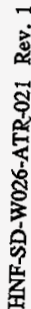

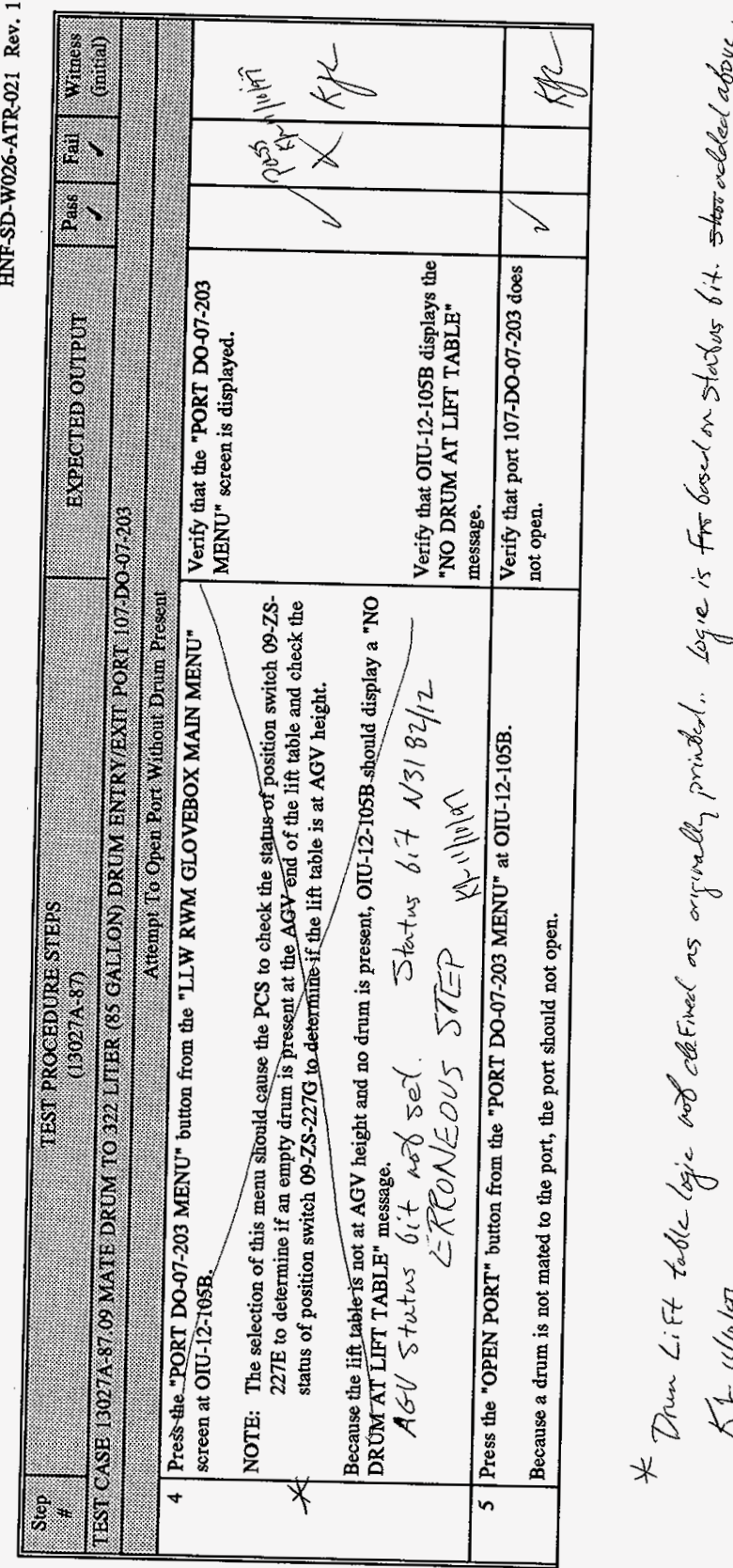

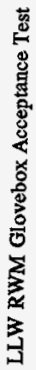

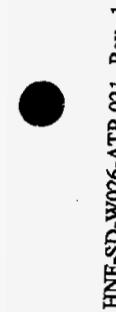


HNF-SD-W026-ATR-021 Rev. 1

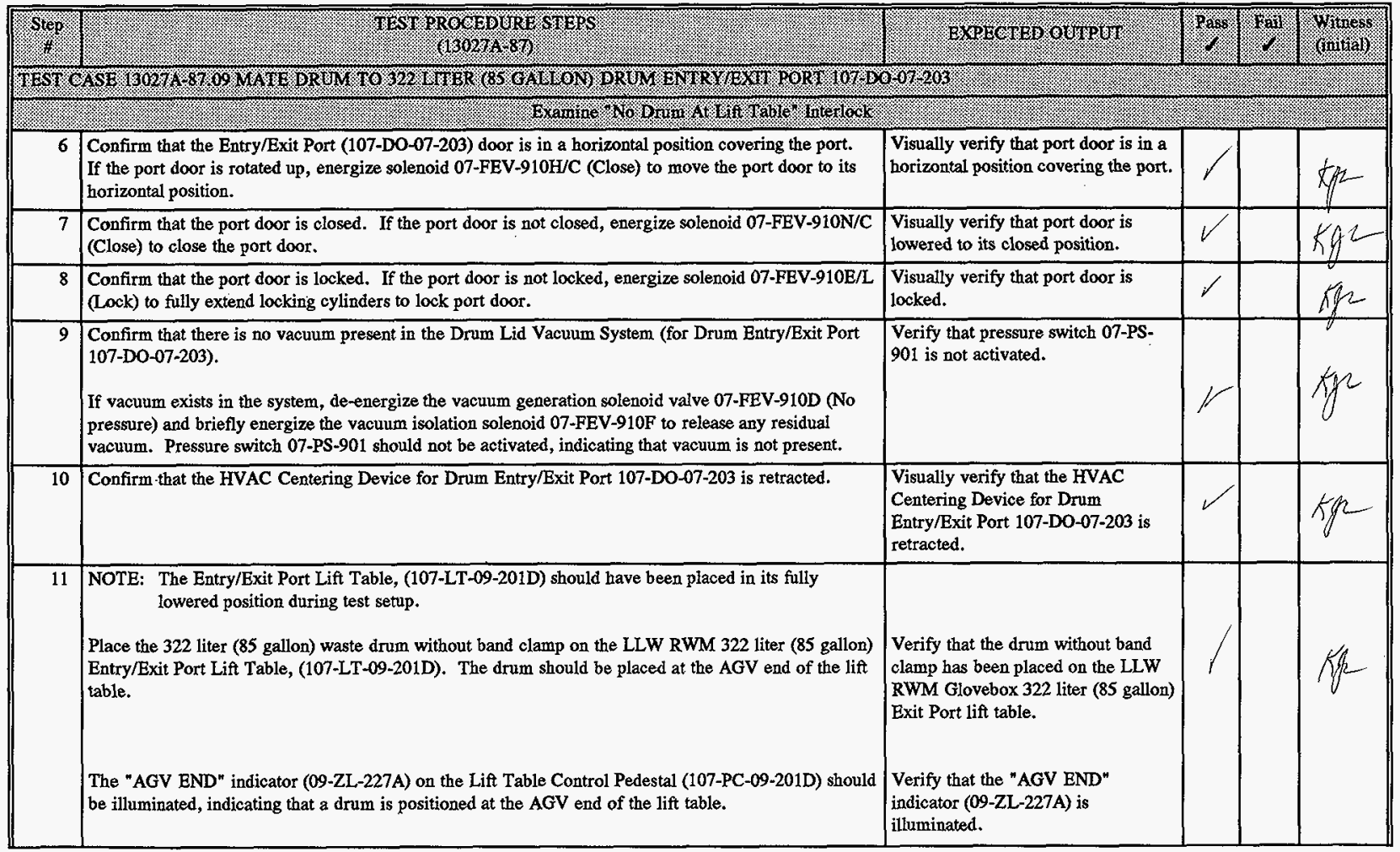


HNF-SD-W026-ATR-021 Rev. 1

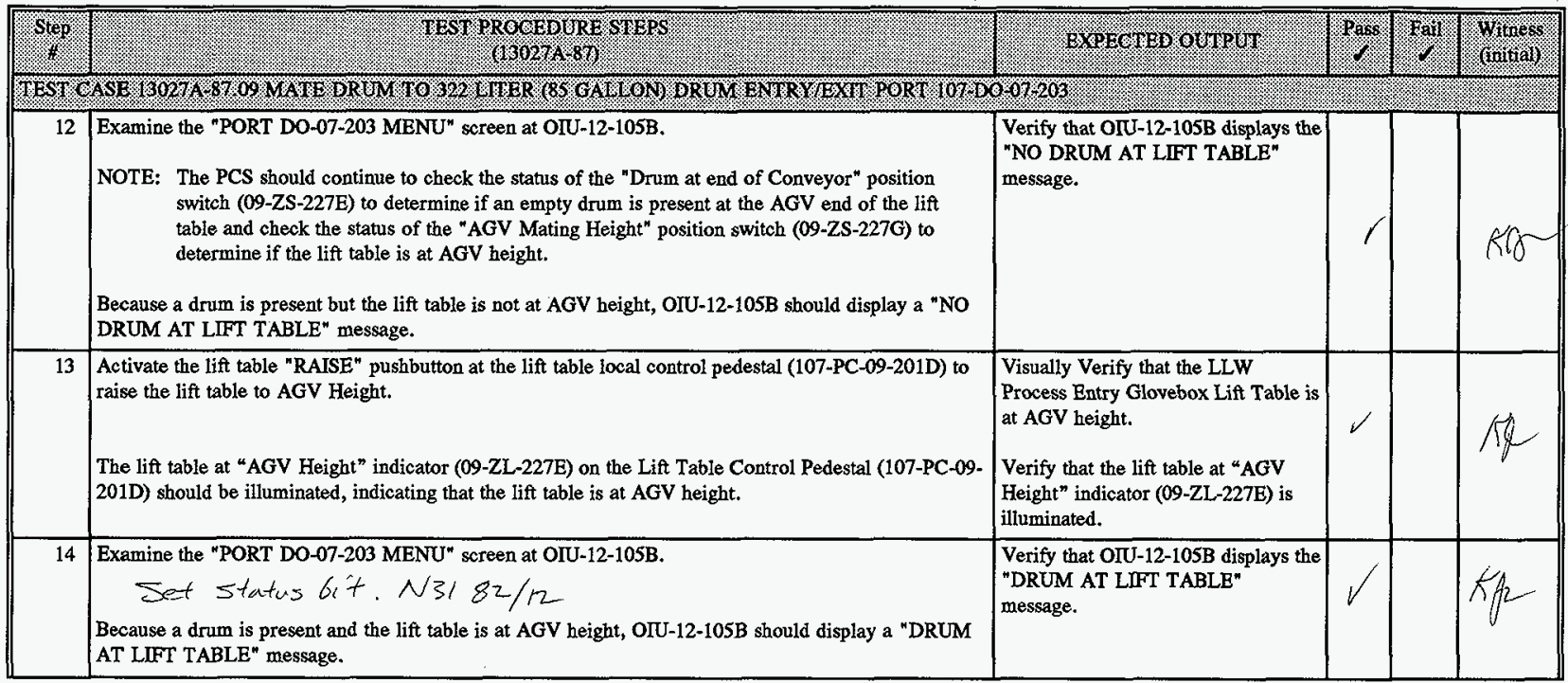


HNF-SD-W026-ATR-021 Rev. 1

\begin{tabular}{|c|c|c|c|c|c|}
\hline Siep: & 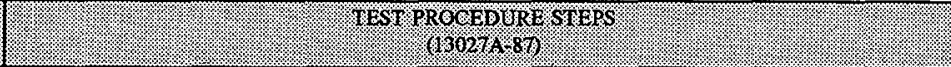 & 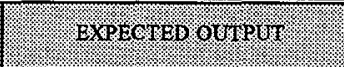 & rasso & की. & (rintial) \\
\hline \multicolumn{6}{|c|}{ 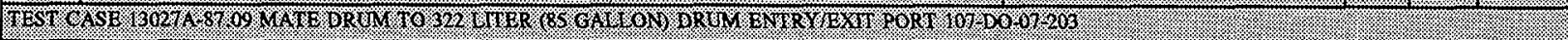 } \\
\hline \multicolumn{6}{|c|}{ 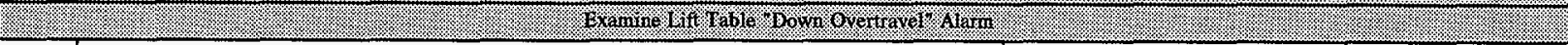 } \\
\hline 15 & $\begin{array}{l}\text { Manually activate the "Down Overtravel" position switch (09-ZS-227C) to simulate that lift table (107- } \\
\text { LT-09-201D) has been lowered below its normal travel height. } \\
\text { The "DOWN OVERTRAVEL" status indicator }(09-Z L-227 C) \text { at the Lift Table Local Control Pedestal } \\
\text { (107-PC-09-201D) should be illuminated, indicating that the "Down Overtravel" position switch (09- } \\
\text { ZS-227C) has been activated. }\end{array}$ & $\begin{array}{l}\text { Verify that the "Down Overtravel" } \\
\text { position switch (09-ZS-227C) is } \\
\text { briefly activated. } \\
\text { Verify that the "DOWN } \\
\text { OVERTRAVEL" indicator (09-ZL- } \\
227 C) \text { remains illuminated. }\end{array}$ & & & \\
\hline 16 & $\begin{array}{l}\text { Activate the lift table "LOWER" pushbuttons at the lift table local control pedestal (107-PC-09-201D) } \\
\text { to attempt energize lift table motor 107-LT-09-201D/M1. } \\
\text { Because the lift table overtravel switch is activated, the lift table should not lower and the Bagless } \\
\text { Transfer Port should not be enabled. }\end{array}$ & $\begin{array}{l}\text { Verify that the lift table does not } \\
\text { lower. }\end{array}$ & & & \\
\hline 17 & $\begin{array}{l}\text { Review the "PORT DO-07-203 MENU" status. A flashing "SEQUENCE FAILED" message should } \\
\text { be displayed and the "ALARMS" button should be flashing. } \\
\text { Press the "ALARMS" button. The "LOCAL ALARMS" screen should be displayed, with a flashing } \\
\text { "Lift Table (201D) Down Overtravel" alarm. } \\
\text { Press the "LOCAL ALARMS" screen to display the "LOCAL ALARMS" screen. Buttons should be } \\
\text { displayed near the bottom of the screen to allow alarms to be acknowledged. An active "Lift Table } \\
\text { (201D) Down Overtravel" alarm should be displayed on this screen. }\end{array}$ & $\begin{array}{l}\text { Verify that a flashing "SEQUENCE } \\
\text { FAIED" message is displayed and } \\
\text { the "ALARMS" button is flashing. } \\
\text { Verify that the "LOCAL ALARMS" } \\
\text { screen is displayed with the active } \\
\text { alarm flashing. } \\
\text { Verify that the "LOCAL ALARMS" } \\
\text { screen with an active "Lift Table } \\
\text { (201D) Down Overtravel" alarm is } \\
\text { displayed. }\end{array}$ & $\checkmark$ & & \\
\hline
\end{tabular}


HNF-SD-W026-ATR-021 Rev. 1

\begin{tabular}{|c|c|c|c|c|c|}
\hline Sep & IEST PROGEDURESTERS & EXPECTEB GUYP & Pros & Fin. & (initial) \\
\hline \multicolumn{6}{|c|}{ 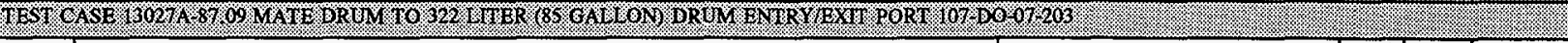 } \\
\hline 18 & $\begin{array}{l}\text { Press the bottom area of the "LOCAL ALARMS" screen to activate the alarm selector feature. The } \\
\text { currently selected alarm should be highlighted. Press the up and down arrow buttons as needed to } \\
\text { select the appropriate alarm. } \\
\text { Press the "ACK" button to acknowledge the selected alarm. } \\
\text { Press the "DONE" button to return to the "LOCAL ALARMS" screen. }\end{array}$ & $\begin{array}{l}\text { Verify that the appropriate alarm is } \\
\text { selected (highlighted). } \\
\text { Verify that the selected alarm is } \\
\text { acknowledged. } \\
\text { Verify that the "LOCAL ALARMS" } \\
\text { screen is displayed and that the } \\
\text { acknowledged "Lift Table (201D) } \\
\text { Down Overtravel" alarm is displayed } \\
\text { on this screen. }\end{array}$ & $\checkmark$ & & \\
\hline 19 & $\begin{array}{l}\text { Manually reset the "Down Overtravel" position switch (09-ZS-227C) to indicate that the lift table (107- } \\
\text { LT-09-201D) is positioned within its normal vertical travel range. } \\
\text { Resetting the "Down Overtravel" position switch (09-ZS-227C) should cause the "Lift Table (201D) } \\
\text { Down Overtravel" alaron to clear. } \\
\text { The "DOWN OVERTRAVEL" status indicator (09-ZL-227C) at the Lift Table Local Control Pedestal } \\
(107-P C-09-201 D) \text { should not be illuminated, indicating that the "Down Overtravel" position switch } \\
(09-Z S-227 C) \text { is not activated. }\end{array}$ & $\begin{array}{l}\text { Verify that the steady yellow alarm } \\
\text { message has changed to green. } \\
\text { Verify that the "Lift Table (201D) } \\
\text { Down Overtravel" alarm is clear. } \\
\text { Verify that the "DOWN } \\
\text { OVBRTRAVEL" status indicator } \\
\text { (09-ZL-227C) is not illuminated. }\end{array}$ & $\checkmark$ & & \\
\hline 20 & Press the "RETURN TO CURRENT SCREEN" button to return to the "PORT DO-07-203 MENU". & $\begin{array}{l}\text { Verify that the "PORT DO-07-203 } \\
\text { MENU" is displayed with a "DRUM } \\
\text { AT LIFT TABLE" message. }\end{array}$ & $\checkmark$ & & 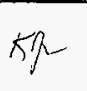 \\
\hline
\end{tabular}


HNF-SD-W026-ATR-021 Rev. 1

\begin{tabular}{|c|c|c|c|c|c|}
\hline Stev, & 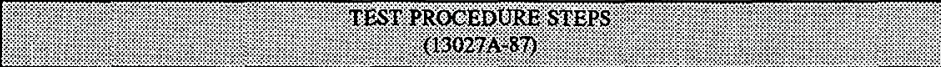 & 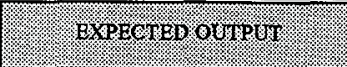 & Pros. & I. & Wintiess \\
\hline \multicolumn{6}{|c|}{ 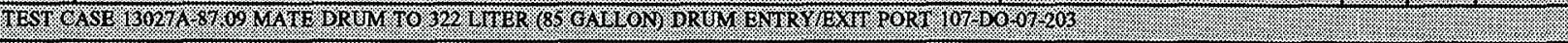 } \\
\hline 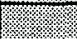 & f. & & & & \\
\hline 21 & $\begin{array}{l}\text { Manually activate the "Up Overtravel" position switch (09-ZS-227D) to simulate that lift table (107- } \\
\text { LT-09-20ID) has been raised above its normal travel height. }\end{array}$ & $\begin{array}{l}\text { Verify that "Up Overtravel" position } \\
\text { switch (09-ZS-227D) has been } \\
\text { activated. }\end{array}$ & & & \\
\hline 22 & $\begin{array}{l}\text { Review the "PORT DO-07-203 MENU" status. A flashing "SEQUENCE FAILED" message should } \\
\text { be displayed and the "ALARMS" button shouid be flashing. } \\
\text { Press the "ALARMS" button. The "LOCAL ALARMS" screen should be displayed, with a flashing } \\
\text { "Lift Table 201D Up Overtravel" alarm. } \\
\text { Press the "LOCAL ALARMS" screen to display the "LOCAL ALARMS" screen. Buttons should be } \\
\text { displayed near the bottom of the screen to allow alarms to be acknowledged. An active "Lift Table } \\
\text { 201D Up Overtravel" alarm should be displayed on this screen. }\end{array}$ & $\begin{array}{l}\text { Verify that a flashing "SEQUENCE } \\
\text { FAILED" message is displayed and } \\
\text { the "ALARMS" button is flashing. } \\
\text { Verify that the "LOCAL ALARMS" } \\
\text { screen is displayed with the active } \\
\text { alarm flashing. } \\
\text { Verify that the "LOCAL ALARMS" } \\
\text { screen with an active "Lift Table } \\
\text { 201D Up Overtravel" alarm is } \\
\text { displayed. }\end{array}$ & $\mathscr{L}$ & & \\
\hline 23 & $\begin{array}{l}\text { Press the bottom area of the "LOCAL ALARMS" screen to activate the alarm selector feature. The } \\
\text { currently selected alarm should be highlighted. Press the up and down arrow buttons as needed to } \\
\text { select the appropriate alarm. } \\
\text { Press the "ACK" button to acknowledge the selected alarm. } \\
\text { Press the "DONE" button to return to the "LOCAL ALARMS" screen. }\end{array}$ & $\begin{array}{l}\text { Verify that the appropriate alarm is } \\
\text { selected (highlighted). } \\
\text { Verify that the selected alarm is } \\
\text { acknowledged. } \\
\text { Verify that the "LOCAL ALARMS" } \\
\text { screen is displayed and that the } \\
\text { acknowledged "Lift Table 201D Up } \\
\text { Overtravel" alarm is displayed on } \\
\text { this screen. }\end{array}$ & 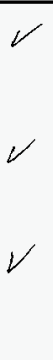 & & kn \\
\hline
\end{tabular}


HNF-SD-W026-ATR-021 Rev. 1

\begin{tabular}{|c|c|c|c|c|c|}
\hline sted & TEST PRGQEDUURE STEPS & 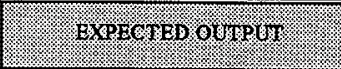 & Pass: & 2. & \\
\hline \multicolumn{6}{|c|}{ 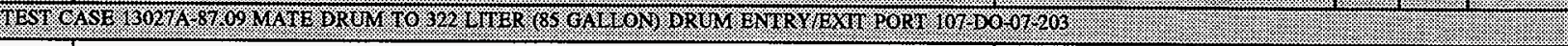 } \\
\hline 24 & $\begin{array}{l}\text { Activate the lift table "RAISE" pushbuttons at the lift table local control pedestal (107-PC-09-201D) to } \\
\text { attempt to energize lift table motor 107-LT-09-201D/M1. } \\
\text { Because the lift table overtravel switch is activated, the lift table should not rise. }\end{array}$ & $\begin{array}{l}\text { Verify that the lift table does not } \\
\text { rise. }\end{array}$ & & & \\
\hline 25 & $\begin{array}{l}\text { Manually reset the "Up Overtravel" position switch (09-ZS-227D) to indicate that lift table 107-LT-09- } \\
201 \mathrm{D} \text { is positioned within its normal vertical travel range. } \\
\text { Resetting the "Up Overtravel" position switch (09-ZS-227D) should cause the "Lift Table 201D Up } \\
\text { Overtravel" alarm to clear. } \\
\text { Press the "RETURN TO CURRENT SCREEN" button to return to the "PORT DO-07-203 MENU" at } \\
\text { 107-OIU-12-105B. }\end{array}$ & $\begin{array}{l}\text { Verify that lift table overtravel } \\
\text { switch 09-ZS-227D is not activated, } \\
\text { indicating that the lift table has not } \\
\text { been raised past its travel limit. } \\
\text { Verify that the "Lift Table 201D Up } \\
\text { Overtravel" alarm is clear. } \\
\text { Verify that the "PORT DO-07-203 } \\
\text { MENU" is displayed. }\end{array}$ & $\checkmark$ & & \\
\hline
\end{tabular}


HNF-SD-W026-ATR-021 Rev. 1

\begin{tabular}{|c|c|c|c|c|c|}
\hline siep. & TEST PROCEOURE STEPS : & 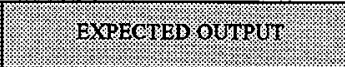 & 8 & Fat & (rinina) \\
\hline \multicolumn{6}{|c|}{ 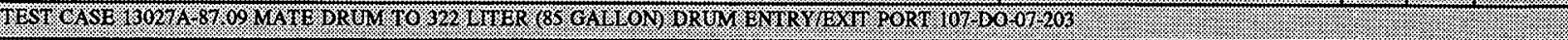 } \\
\hline \multicolumn{6}{|c|}{ 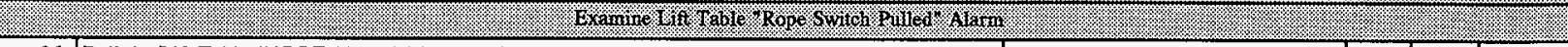 } \\
\hline 26 & $\begin{array}{l}\text { Pull the Lift Table (107-LT-09-201D) Rope Switches to disable all lift table operations. } \\
\text { Press all pushbuttons on the Lift Table Local Control Pedestal (107-PC-09-201D) in both "Normal" } \\
\text { and "Maintenance" modes (Use Lift Table Local Control Pedestal M/O/N switch to switch between } \\
\text { operating modes). Because the rope switches have been pulled, pressing the buttons should have no } \\
\text { effect on the lift table. }\end{array}$ & $\begin{array}{l}\text { Verify that the rope switches have } \\
\text { been pulled. } \\
\text { Verify that pressing the Lift Table } \\
\text { Local Control Pedestal pushbuttons } \\
\text { has no effect on the lift table. }\end{array}$ & & & \\
\hline 27 & $\begin{array}{l}\text { Review the "PORT DO-07-203 MENU" status. A flashing "SEQUENCE FAILED" message should } \\
\text { be displayed and the "ALARMS" button should be flashing. } \\
\text { Press the "ALARMS" button. The "LOCAL ALARMS" screen should be displayed, with a flashing } \\
\text { "Lift Table (201D) Rope Sw. Pulled" alarm. } \\
\text { Press the "LOCAL ALARMS" screen to display the "LOCAL ALARMS" screen. Buttons should be } \\
\text { displayed near the bottom of the screen to allow alarms to be acknowledged. An active "Lift Table } \\
\text { (201D) Rope Sw. Pulled" alarm should be displayed on this screen. }\end{array}$ & $\begin{array}{l}\text { Verify that a flashing "SEQUENCE } \\
\text { FAILED" message is displayed and } \\
\text { the "ALARMS" button is flashing. } \\
\text { Verify that the "LOCAL ALARMS" } \\
\text { screen is displayed with the active } \\
\text { alarm flashing. } \\
\text { Verify that the "LOCAL ALARMS" } \\
\text { screen with an active "Lift Table } \\
\text { (201D) Rope Sw. Pulled" alarm is } \\
\text { displayed. }\end{array}$ & $\checkmark$ & & \\
\hline 28 & $\begin{array}{l}\text { Press the bottom area of the "LOCAL ALARMS" screen to activate the alarm selector feature. The } \\
\text { currently selected alarm should be highlighted. Press the up and down arrow buttons as needed to } \\
\text { select the appropriate alarm. } \\
\text { Press the "ACK" button to acknowledge the selected alarm. } \\
\text { Press the "DONE" button to return to the "LOCAL ALARMS" screen. }\end{array}$ & $\begin{array}{l}\text { Verify that the appropriate alarm is } \\
\text { selected (highlighted). } \\
\text { Verify that the selected alarm is } \\
\text { acknowledged. } \\
\text { Verify that the "LOCAL ALARMS" } \\
\text { screen is displayed and that the } \\
\text { acknowledged "Lift Table (201D) } \\
\text { Rope Sw. Pulled" alarm is displayed } \\
\text { on this screen. }\end{array}$ & $\gamma$ & & $\mathrm{kg}$ \\
\hline
\end{tabular}




\begin{tabular}{|c|c|c|c|c|c|}
\hline $2,2, y$ & & $\Lambda$ & 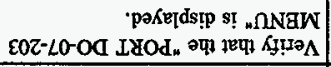 & 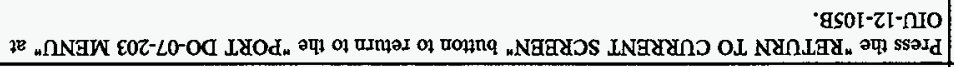 & OE \\
\hline$H y$ & & $\begin{array}{l}1 \\
\not 2\end{array}$ & 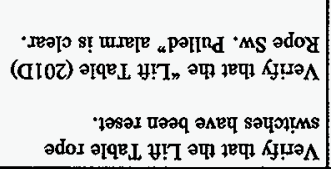 & 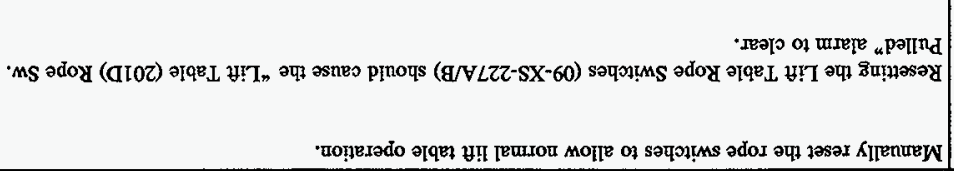 & 62 \\
\hline \multicolumn{6}{|c|}{ 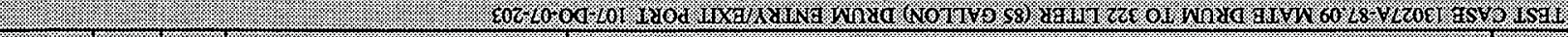 } \\
\hline singining & $\sqrt{8}$ & (3) & Mudrougragad & 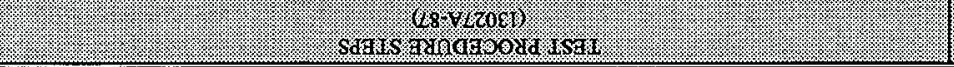 & inis: \\
\hline
\end{tabular}


HNF-SD-W026-ATR-021 Rev. 1

\begin{tabular}{|c|l|l|l|l|l|l}
\hline Activate the "FORWARD" pushbutton at the lift table local control pedestal (107-PC-09-201D) to \\
energize the lift table conveyor motor forward (107-LT-09-201D/M2). \\
\begin{tabular}{|c|l|l|l}
\hline Because the lift table is not lowered, as indicated by position switch 09-ZS-227C, the "FORWARD" \\
pushbutton should be disabled by the PCS.
\end{tabular}
\end{tabular}




\begin{tabular}{|c|c|c|c|c|c|}
\hline (5ep & IEST PROQEDURE STEPS : & 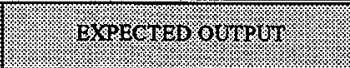 & $\left(\frac{9}{8}\right)$ & tis: & (nitial) \\
\hline \multicolumn{6}{|c|}{ 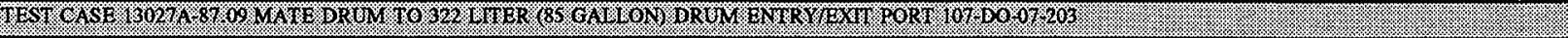 } \\
\hline \multicolumn{6}{|c|}{ 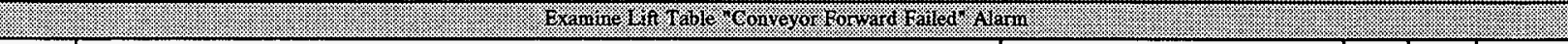 } \\
\hline 35 & $\begin{array}{l}\text { Activate the "REVERSE" pushbutton at the Lift Table Local Control Pedestal (107-PC-09-201D) to } \\
\text { energize the lift table conveyor motor reverse (107-LT-09-201D/M2). } \\
\text { The lift table conveyor motor should de-energize when the drum breaks the light beam at the AGV } \\
\text { end. }\end{array}$ & $\begin{array}{l}\text { Verify that the conveyor motor } \\
\text { should de-energize. }\end{array}$ & & & \\
\hline 36 & $\begin{array}{l}\text { NOTE: This step will be used to simulate a power failure at the lift table. The } 480 \text { volt lift table } \\
\text { local disconnect will be opened during drum transfer under the glovebox port. } \\
\text { Activate the "FORWARD" pushbutton at the Lift Table Local Control Pedestal (107-PC-09-201D) to } \\
\text { energize the lift table conveyor motor forward (107-LT-09-201D/M2). After drum has moved } \\
\text { approximately one foot, open the } 480 \text { volt lift table local disconnect to remove power from the lift } \\
\text { table. } \\
\text { The roller conveyor should stop. After approximately } 10 \text { seconds, close the } 480 \text { volt lift table local } \\
\text { disconnect to restore power to the lift table. The roller conveyor should not start up again after power } \\
\text { is restored. }\end{array}$ & $\begin{array}{l}\text { Verify that the lift table roller } \\
\text { conveyors have stopped and remain } \\
\text { stopped. }\end{array}$ & $\checkmark$ & & \\
\hline 37 & $\begin{array}{l}\text { Review the "PORT DO-07-203 MENU" status. A flashing "SEQUENCE FALED" message should } \\
\text { be displayed and the "ALARMS" button should be flashing. } \\
\text { Press the "ALARMS" button. The "LOCAL ALARMS" screen should be displayed, with a flashing } \\
\text { "Lift Table (201D) Conveyor Fwd Failed" alarm. } \\
\text { Press the "LOCAL ALARMS" screen to display the "LOCAL ALARMS" screen. Buttons should be } \\
\text { displayed near the bottom of the screen to allow alarms to be acknowledged. An active "Lift Table } \\
\text { (201D) Conveyor Fwd Failed" alarm should be displayed on this screen. }\end{array}$ & $\begin{array}{l}\text { Verify that a flashing "SEQUENCE } \\
\text { FAILED" message is displayed and } \\
\text { the "ALARMS" button is flashing. } \\
\text { Verify that the "LOCAL ALARMS" } \\
\text { screen is displayed with the active } \\
\text { alarm flashing. } \\
\text { Verify that the "LOCAL ALARMS" } \\
\text { screen with an active "Lift Table } \\
\text { (201D) Conveyor Fwd Failed" alarm } \\
\text { is displayed. }\end{array}$ & $\begin{array}{l}V \\
V\end{array}$ & & \\
\hline
\end{tabular}


HNF-SD-W026-ATR-021 Rev. 1

\begin{tabular}{|c|c|c|c|c|c|}
\hline sen: & TEST PRGCEOURF STEPS & 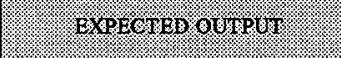 & 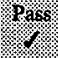 & (6ation & Vininess \\
\hline \multicolumn{6}{|c|}{ 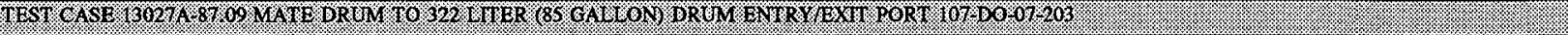 } \\
\hline \multirow[t]{3}{*}{38} & $\begin{array}{l}\text { Press the bottom area of the "LOCAL ALARMS" screen to activate the alarm selector feature. The } \\
\text { currently selected alarm should be highlighted. Press the up and down arrow buttons as needed to } \\
\text { select the appropriate alarm. }\end{array}$ & $\begin{array}{l}\text { Verify that the appropriate alarm is } \\
\text { selected (highlighted). }\end{array}$ & $\checkmark$ & & $\mathrm{kgh}$ \\
\hline & Press the "ACK" button to acknowledge the selected alarm. & $\begin{array}{l}\text { Verify that the selected alarm is } \\
\text { acknowledged. }\end{array}$ & $\checkmark$ & & $k \not h$ \\
\hline & Press the "DONE" button to return to the "LOCAL ALARMS" screen. & $\begin{array}{l}\text { Verify that the "LOCAL ALARMS" } \\
\text { screen is displayed and that the } \\
\text { acknowledged "Lift Table (201D) } \\
\text { Conveyor Fwd Failed" alarm is } \\
\text { displayed on this screen. }\end{array}$ & V & & $K g_{2}$ \\
\hline 39 & $\begin{array}{l}\text { Press the "RETURN TO CURRENT SCREEN" button to return to the "PORT DO-07-203 MENU" at } \\
\text { 107-OIU-12-105B. }\end{array}$ & $\begin{array}{l}\text { Verify that the "PORT DO-07-203 } \\
\text { MENU" is displayed and the screen } \\
\text { status displays "Sequence failed". }\end{array}$ & V & & \\
\hline
\end{tabular}




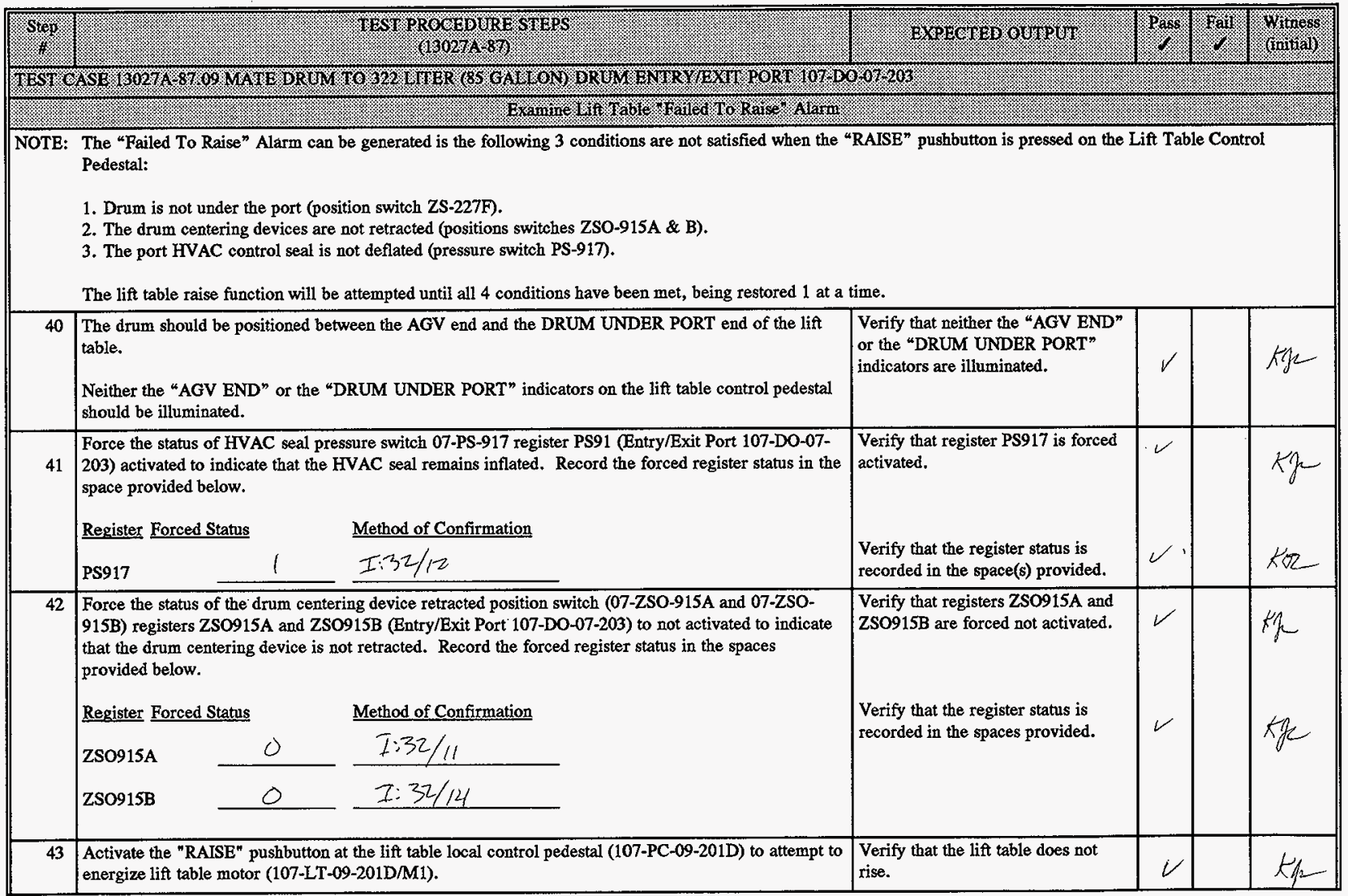


HNF-SD-W026-ATR-021 Rev. 1

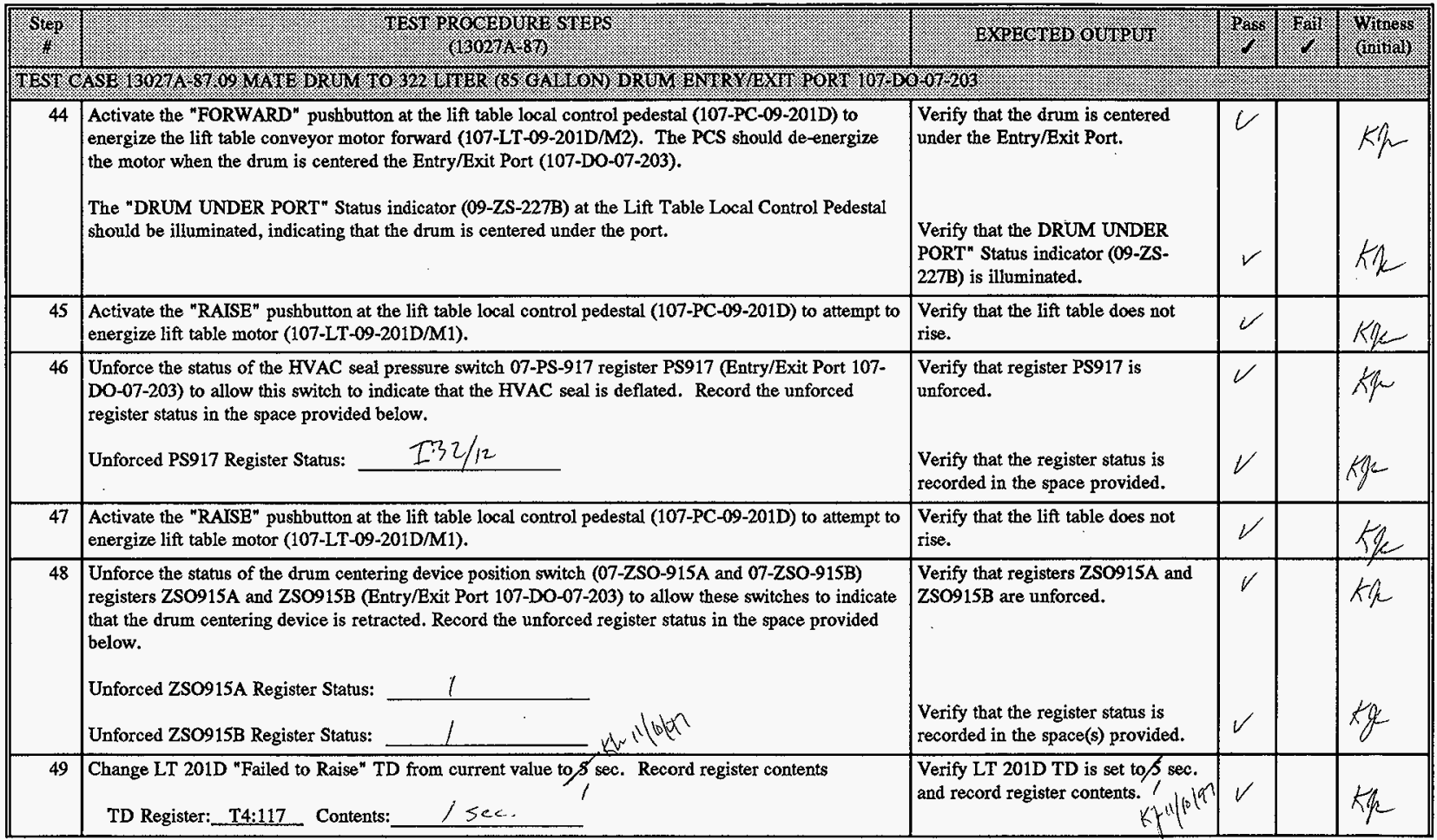




\begin{tabular}{|c|c|c|c|c|c|}
\hline step & TEST PROCEDURP STEPS & PXPECIIBP OUTPYY & 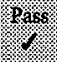 & 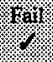 & Winitivil: \\
\hline \multicolumn{6}{|c|}{ 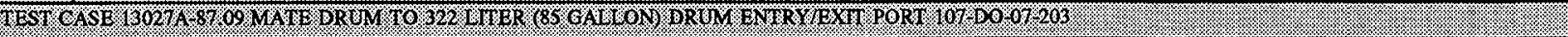 } \\
\hline 50 & $\begin{array}{l}\text { Activate the "RAISE" pushbutton at the lift table local control pedestal (107-PC-09-201D) to energize } \\
\text { the lift table conveyor motor (107-LT-09-201D/M1) to raise the lift table. } \\
\text { Because a drum is present under the Entry/Exit Port, as indicated by position switch 09-ZS-227F, the } \\
\text { "RAISE" pushbutton should be enabled by the PCS and the drum should rise to the "Drum Centering" } \\
\text { position. } \\
\text { Record the "Drum Centering" position height in the space provided below; } \\
\text { Drum Centering Height: }\end{array}$ & $\begin{array}{l}\text { Verify that the drum rises to the } \\
\text { "Drum Centering" Position. }\end{array}$ & $\sqrt{ }$ & & \\
\hline $\begin{array}{l}63 a \\
k y^{11}\end{array}$ & $\begin{array}{l}\text { Review the "PORT DO-07-203 MENU" status. A flashing "SEQUENCE FAILED" message should } \\
\text { be displayed and the "ALARMS" button should be flashing. } \\
\text { Press the "ALARMS" button. The "LOCAL ALARMS" screen should be displayed, with a flashing } \\
\text { "Lift Table (201D) Failed to Raise" alarm. } \\
\text { Press the "LOCAL ALARMS" screen to display the "LOCAL ALARMS" screen. Buttons should be } \\
\text { displayed near the bottom of the screen to allow alarms to be acknowledged. An active "Lift Table } \\
\text { (201D) Failed to Raise" alarm should be displayed on this screen. }\end{array}$ & $\begin{array}{l}\text { Verify that a flashing "SEQUENCE } \\
\text { FAIIED" message is displayed and } \\
\text { the "ALARMS" button is flashing. } \\
\text { Verify that the "LOCAL, ALARMS" } \\
\text { screen is displayed with the active } \\
\text { alarm flashing. } \\
\text { Verify that the "ACTIVE ALARMS" } \\
\text { screen with an active "Lift Table } \\
\text { (201D) Failed to Raise" alarm is } \\
\text { displayed. }\end{array}$ & $\nu$ & & $9 / 8$ \\
\hline $\begin{array}{r}52 \\
636 \\
k+11 \mid\end{array}$ & $\begin{array}{l}\text { Press the bottom area of the "LOCAL ALARMS" screen to activate the alarm selector feature. The } \\
\text { currently selected alarm should be highlighted. Press the up and down arrow buttons as needed to } \\
\text { select the appropriate alarm. } \\
\text { Press the "ACK" button to acknowledge the selected alarm. } \\
\text { Press the "DONE" button to return to the "LOCAL ALARMS" screen. }\end{array}$ & $\begin{array}{l}\text { Verify that the selected alarm is } \\
\text { acknowledged. } \\
\text { Verify that the "LOCAL ALARMS" } \\
\text { screen is displayed and that the } \\
\text { acknowledged "Lift Table (201D) } \\
\text { Failed to Raise" alarm is displayed } \\
\text { on this screen. }\end{array}$ & & & $1 / 8 / 87$ \\
\hline
\end{tabular}


HNF-SD-W026-ATR-021 Rev. 1

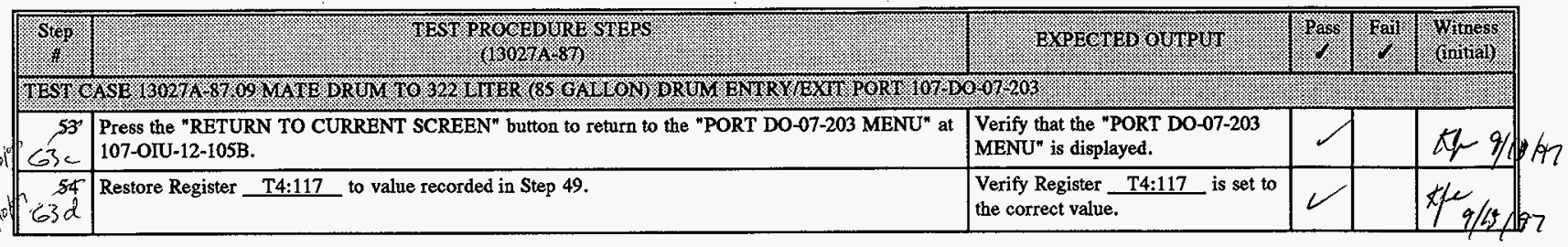


HNF-SD-W026-ATR-021 Rev. 1

\begin{tabular}{|c|c|c|c|c|c|}
\hline St:? & 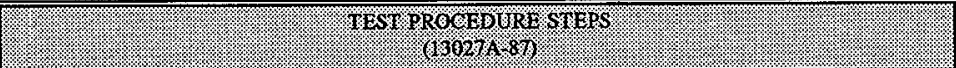 & EXPECTED OKTIY & pas & (19.7. & (rintivil) \\
\hline \multirow{2}{*}{\multicolumn{6}{|c|}{ 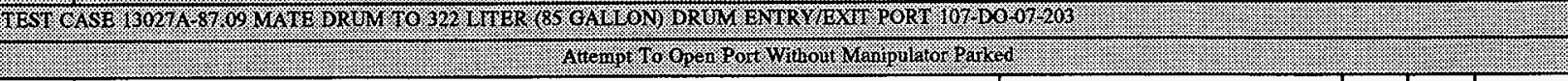 }} \\
\hline & & & & & \\
\hline 55 & $\begin{array}{l}\text { NOTE: The manipulator serves as an interlock for Entry/Exit Port operation. When the manipulator } \\
\text { is not at the park position, the Entry/Exit Port should not be able to open. The manipulator is } \\
\text { initially slightly displaced from the park position to allow this interlock to be tested. } \\
\text { Place the LLW RWM Waste Manipulator (107-EM-07-201) approximately one foot from park position } \\
\text { (Closest to Bagless Transfer Port (107-DO-07-201) with both manipulator arms fully parked. } \\
\text { Kf il lil } 19 \text { ' }\end{array}$ & $\begin{array}{l}\text { Visually verify that the waste } \\
\text { manipulator is approximately one } \\
\text { foot away park position } 1 \text { with both } \\
\text { arms parked. }\end{array}$ & $\sqrt{ }$ & & \\
\hline 56 & $\begin{array}{l}\text { Press the "OPEN PORT" button from the "PORT DO-07-203 MENU" screen at OIU-12-105B. } \\
\text { Because the manipulator is not parked, the lift table should not raise the drum and the port (107-DO- } \\
07-203 \text { ) should not open. }\end{array}$ & $\begin{array}{l}\text { Verify that the lift table does not } \\
\text { rise. } \\
\text { Verify that the port does not open. }\end{array}$ & 7 & & $K R$ \\
\hline 57 & $\begin{array}{l}\text { Place the LLW RWM Waste Manipulator (107-EM-07-201) at park position } X \text { (Closest to Bagless } \\
\text { Transfer Port (107-DO-07-201) with both manipulator arms fully parked. }\end{array}$ & $\begin{array}{l}\text { Visually verify that the waste } \\
\text { manipulator is at park position } X \text { with } \\
\text { both arms parked. }\end{array}$ & $V$ & & 4 \\
\hline
\end{tabular}


HNF-SD-W026-ATR-021 Rev. 1

\begin{tabular}{|c|c|c|c|c|c|}
\hline step & TEST PRCGEDURE STER . & 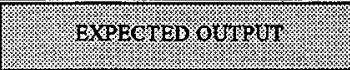 & pass. & Far. & (nitin) \\
\hline \multicolumn{6}{|c|}{ 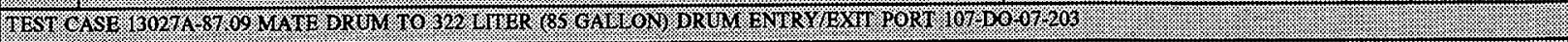 } \\
\hline \multicolumn{6}{|c|}{ 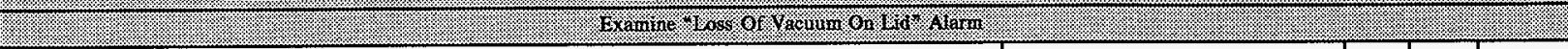 } \\
\hline 58 & 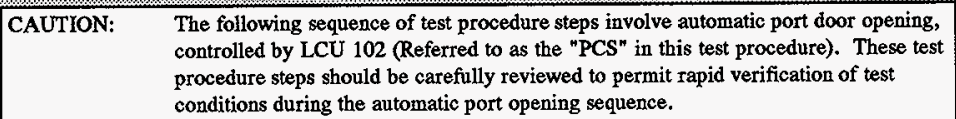 & $\begin{array}{l}\text { Verify that the remaining test } \\
\text { procedure steps in this test case are } \\
\text { carefully reviewed prior to } \\
\text { completing this test case. }\end{array}$ & $\checkmark$ & & \\
\hline 59 & $\begin{array}{l}\text { NOTE: If the "DOOR IN POSITION" switch 07-ZS-912B register is not activated during the drum } \\
\text { port opening sequence, an error message should be displayed at the OIU. Forcing this switch } \\
\text { not activated allows this error message to be tested. } \\
\text { Force register ZS912B to indicate that the "DOOR IN POSITION" switch 07-ZS-912B is not activated. } \\
\text { Record the forced status of this register in the space provided below. } \\
\text { Register Forced Status } \\
\text { ZS912B }\end{array}$ & $\begin{array}{l}\text { Verify that register ZS912B is forced } \\
\text { to indicate that switch } 07-Z S-912 B \text { is } \\
\text { not activated. } \\
\text { Verify that the register status is } \\
\text { recorded in the space(s) provided. }\end{array}$ & 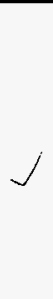 & & \\
\hline 60 & $\begin{array}{l}\text { NOTE: If the "DRUM PORT ROTATED" position switch register is not activated during the drum } \\
\text { port opening sequence, an error message should be displayed at the OrU. Forcing this switch } \\
\text { not activated allows this error message to be tested. } \\
\text { Force register ZSO911 to indicate that the "DRUM PORT ROTATED" position switch 07-ZSO-911 is } \\
\text { not activated. Record the forced status of this register in the space provided below. } \\
\text { Register Forced Status } \\
\text { ZSO911 Z: } 30 / 17\end{array}$ & $\begin{array}{l}\text { Verify that register ZSO911 is forced } \\
\text { to indicate that the "DRUM PORT } \\
\text { ROTATED" position switch 07- } \\
\text { ZSO-911 is not activated } \\
\text { Verify that the register status is } \\
\text { recorded in the space provided. }\end{array}$ & $\checkmark$ & & \\
\hline
\end{tabular}




\begin{tabular}{|c|c|c|c|c|c|}
\hline Step? & 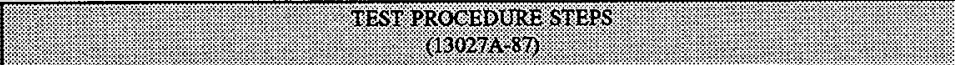 & Experereforourith & Pas: & 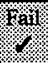 & (initia) \\
\hline \multicolumn{6}{|c|}{ 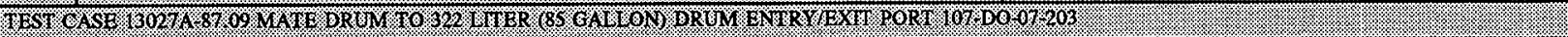 } \\
\hline 61 & $\begin{array}{l}\text { NOTE: If the "SYSTEM ESTABLISHED ADEQUATE VACUUM" pressure switch register is not } \\
\text { activated during the drum port opening sequence, an error message should be displayed at the } \\
\text { OIU. Forcing this switch not activated allows this error message to be tested. } \\
\text { Force register PS901 to indicate that the "SYSTEM ESTABLISHED ADEQUATE VACUUM" } \\
\text { pressure switch 07-PS-901 is not activated. Record the forced status of this register in the space } \\
\text { provided below. } \\
\text { Register Forced Status } \\
\text { PS901 }\end{array}$ & $\begin{array}{l}\text { Verify that register PS901 is forced } \\
\text { to indicate that the "SYSTEM } \\
\text { ESTABLISHED ADEQUATE } \\
\text { VACUUM" pressure switch 07-PS- } \\
901 \text { is not activated. } \\
\text { Verify that the register status is } \\
\text { recorded in the space provided. }\end{array}$ & $V$ & & \\
\hline 62 & $\begin{array}{l}\text { Press the "OPEN PORT" button from the "PORT DO-07-203 MENU" screen at OIU-12-105B. } \\
\text { The PCS should display a "PORT OPENING..." message at OIU-12-105B while the port is opening. } \\
\text { The PCS should automatically energize and hold solenoid 07-FEV-324B, activating the centering } \\
\text { clamps around the drum. }\end{array}$ & $\begin{array}{l}\text { Verify that a "PORT OPENING..." } \\
\text { message is displayed. } \\
\text { Verify that the drum centering } \\
\text { clamps extend, centering the drum } \\
\text { under the port. }\end{array}$ & $\sqrt{ }$ & & \\
\hline $\begin{array}{l}8 / 9163 \\
B<i\end{array}$ & $\begin{array}{l}\text { The PCS should automatically energize lift table motor (107-LT-09-201D/M1) to slowly raise the lift } \\
\text { table until the drum activates position switch } 07-2 S-913 \text {, indicating that the drum is in position to begin } \\
\text { the port opening sequence. }\end{array}$ & $\begin{array}{l}\text { Verify that the lift table rises and } \\
\text { then stops. } \\
1019 ?\end{array}$ & $\checkmark$ & & \\
\hline$\overline{64-}$ & 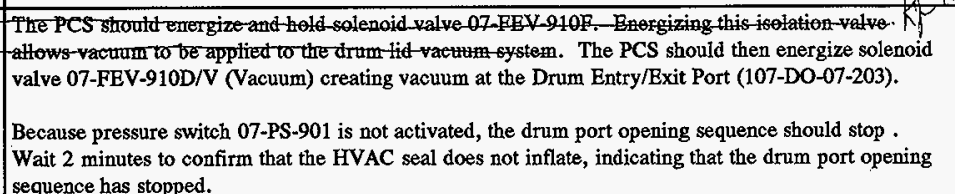 & $\begin{array}{l}\text { Verify that the HVAC seal does not } \\
\text { inflate during the } 2 \text { minute time } \\
\text { period, indicating that the drum port } \\
\text { opening sequence has stopped. }\end{array}$ & $V$ & & $k \geqslant$ \\
\hline
\end{tabular}

see TC 87.09 $g^{16,17}$ 


\begin{tabular}{|c|c|c|c|c|c|}
\hline $3 \geqslant$ & & $\Lambda$ & 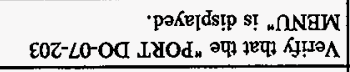 & 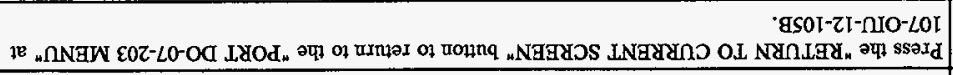 & 89 \\
\hline 7 & & $\rho$ & 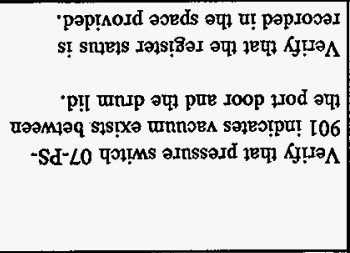 & 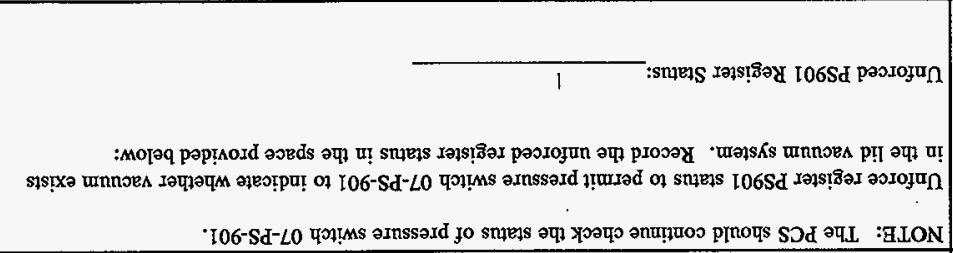 & $\angle 9$ \\
\hline 6 & & $\eta$ & 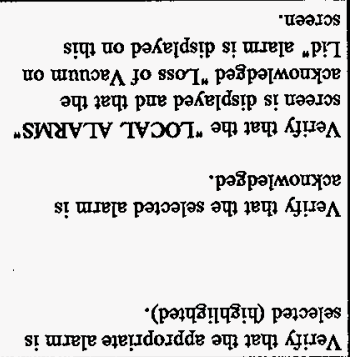 & 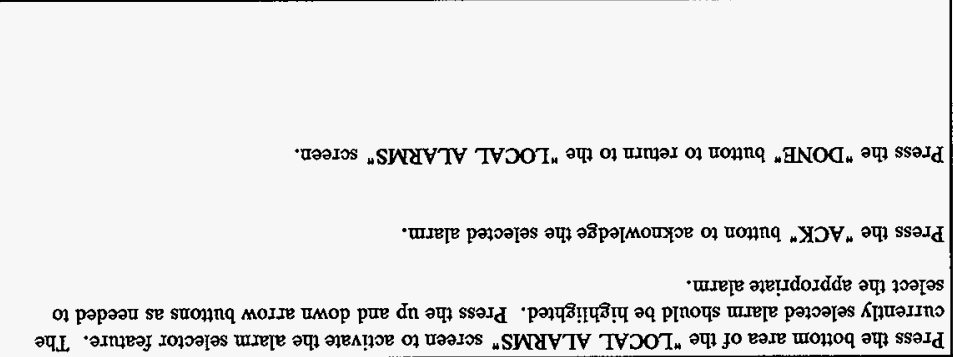 & 99 \\
\hline स्ते & & $\wedge$ & 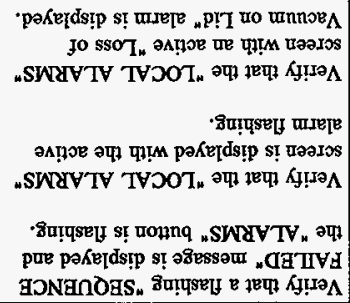 & 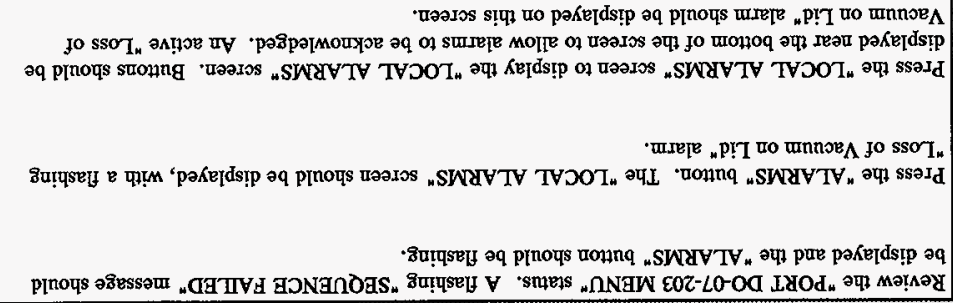 & s9 \\
\hline & & V: & 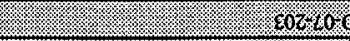 & 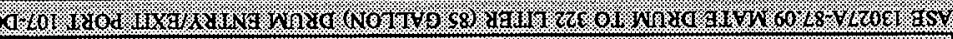 & a.tsat \\
\hline soring & (18) & Wreg & 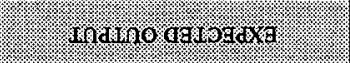 & s. & . \\
\hline
\end{tabular}

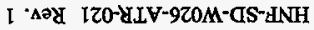




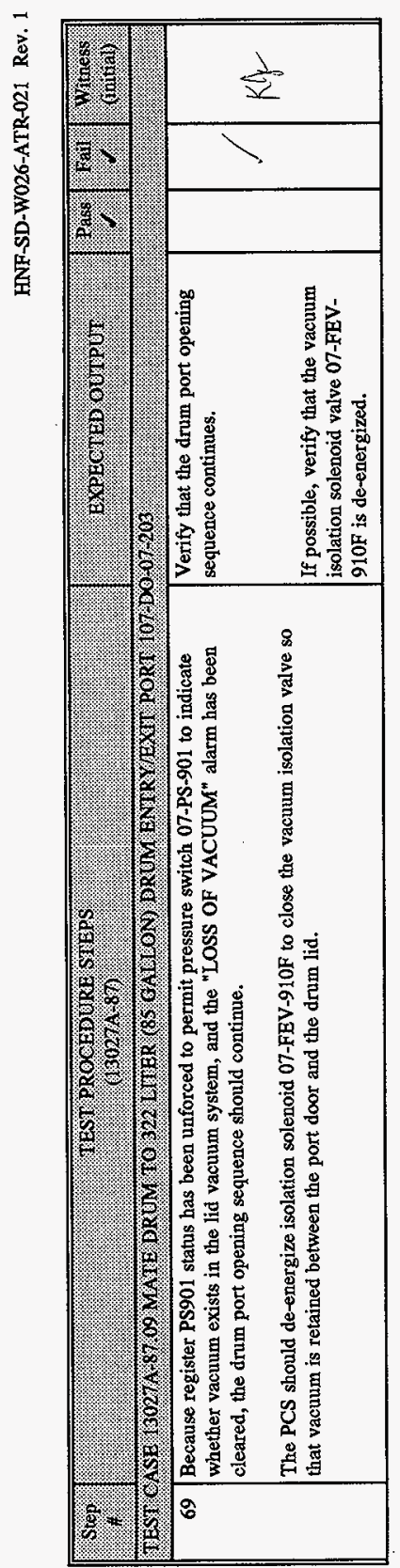

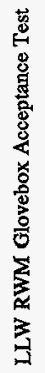

ֻิ 


\begin{tabular}{|c|c|c|c|c|c|}
\hline step. & 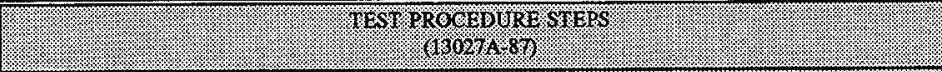 & 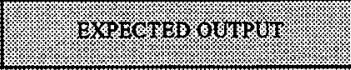 & 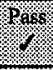 & ton & (initialy \\
\hline \multicolumn{6}{|c|}{ 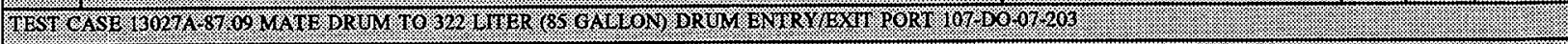 } \\
\hline \multicolumn{6}{|c|}{ 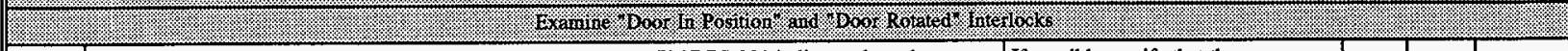 } \\
\hline 70 & $\begin{array}{l}\text { The PCS should check the status of pressure switch } 07-\mathrm{PS}-901 \text {. If } 07-\mathrm{PS}-901 \text { indicates that adequate } \\
\text { vacuum is present, the PCS should de-energize 07-FEV-910D/V. }\end{array}$ & $\begin{array}{l}\text { If possible, verify that the vacuum } \\
\text { generation solenoid valve 07-FEV- } \\
910 \mathrm{D} \text { is de-energized. }\end{array}$ & , & & \\
\hline 71 & $\begin{array}{l}\text { The PCS should energize solenoid valve 07-FEV-325B to inflate the HVAC Seal for Drum Entry/Exit } \\
\text { Port 107-D0-07-203. }\end{array}$ & $\begin{array}{l}\text { Visually verify that the HVAC Seal } \\
\text { for Drum Entry/Exit Port 107-DO- } \\
07-203 \text { is inflated. }\end{array}$ & $V$ & & \\
\hline 72 & $\begin{array}{l}\text { The PCS should briefly energize solenoid valves 07-FEV-913A and 07-FEV-913B (Vent) to release } \\
\text { pressure on the port door open/close cylinders. This allows the cylinders to move freely and should } \\
\text { release any residual pressure on the port door. }\end{array}$ & $\begin{array}{l}\text { If possible, verify that solenoid } \\
\text { valves } 07-\mathrm{FEV}-913 \mathrm{~A} \text { and } 07-\mathrm{FEV} \text { - } \\
913 \mathrm{~B} \text { are briefly energized to release } \\
\text { pressure on the port door open/close } \\
\text { cylinders. }\end{array}$ & $\checkmark$ & & ind \\
\hline 73 & $\begin{array}{l}\text { The PCS should pulse energize solenoid 07-FEV-910E/UL (Unlock) to fully retract the port door } \\
\text { locking cylinders. }\end{array}$ & $\begin{array}{l}\text { Visually verify that both port door } \\
\text { locking cylinders are fully retracted. }\end{array}$ & $v$ & & $k l$ \\
\hline 74 & $\begin{array}{l}\text { The PCS should activate the lift table servo motor (107-LT-09-201D/M1) to raise the lift table, drum, } \\
\text { and port door up until the port door is raised to the "DOOR IN POSITION" height. } \\
\text { Because position switch 07-ZS-912B (Door In Position) is forced not activated, the drum port opening } \\
\text { sequence should stop. Wait } 2 \text { minutes to confirm that the port door does not rise to the "Open" } \\
\text { position, indicating that the drum port opening sequence has stopped. }\end{array}$ & $\begin{array}{l}\text { Visually verify that the lift table rises } \\
\text { causing the drum to lift the port door } \\
\text { to the "Door in Position" height. } \\
\text { Verify that the port door does not } \\
\text { rise to the "Open" position during } \\
\text { the } 2 \text { minute time period, indicating } \\
\text { that the drum port opening sequence } \\
\text { has stopped. }\end{array}$ & $V$ & & $9 / 18497$ \\
\hline
\end{tabular}




\begin{tabular}{|c|c|c|c|c|c|}
\hline Step. & TEST PRO GEV URE STERS & 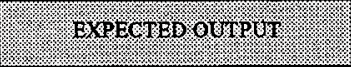 & Ras. & 涪 & (rinivin) \\
\hline \multicolumn{6}{|c|}{ 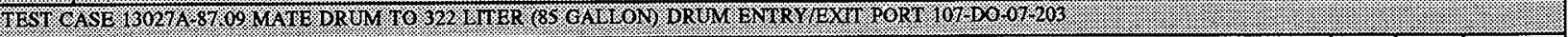 } \\
\hline 75 & 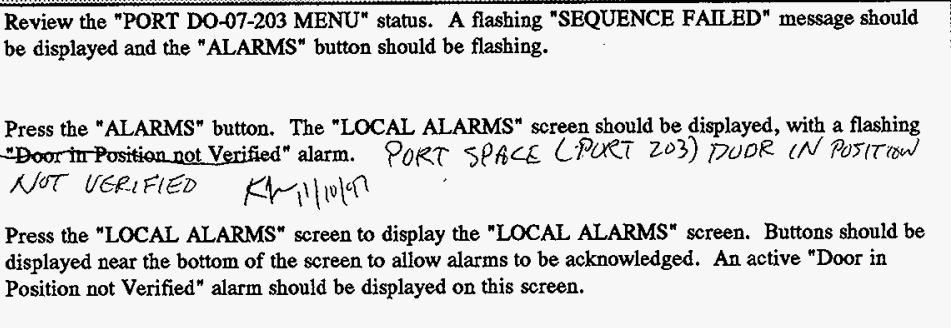 & $\begin{array}{l}\text { Verify that a flashing "SEQUENCE } \\
\text { FAILED" message is displayed and } \\
\text { the "ALARMS" button is flashing. } \\
\text { Verify that the "LOCAL ALARMS" } \\
\text { screen is displayed with the active } \\
\text { alarm flashing. } \\
\text { Verify that the "LOCAL. ALARMS" } \\
\text { screen with an active "Door in } \\
\text { Position not Verified" alarm is } \\
\text { displayed. }\end{array}$ & $V$ & & \\
\hline 76 & $\begin{array}{l}\text { Press the bottom area of the "LOCAL ALARMS" screen to activate the alarm selector feature. The } \\
\text { currently selected alarm should be highlighted. Press the up and down arrow buttons as needed to } \\
\text { select the appropriate alarm. } \\
\text { Press the "ACK" button to acknowledge the selected alarm. } \\
\text { Press the "DONE" button to return to the "LOCAL ALARMS" screen. }\end{array}$ & $\begin{array}{l}\text { Verify that the appropriate alarm is } \\
\text { selected (highlighted). } \\
\text { Verify that the selected alarm is } \\
\text { acknowledged. } \\
\text { Verify that the "LOCAL ALARMS" } \\
\text { screen is displayed and that the } \\
\text { acknowledged "Door in Position not } \\
\text { Verified" alarm is displayed on this } \\
\text { screen. }\end{array}$ & $\nu$ & & \\
\hline 77 & $\begin{array}{l}\text { Unforce register ZS912B status to permit position switch 07-ZS-912B to indicate that the port door is } \\
\text { raised to the "DOOR IN POSITION" height. Record the unforced register status in the space provided } \\
\text { below: } \\
\text { Unforced ZS912B Register Status: OFF } \\
\text { The PCS should continue check the status of position switch 07-ZS-912B. }\end{array}$ & $\begin{array}{l}\text { Verify that position switch } 07-\mathrm{ZS}- \\
912 \mathrm{~B} \text { indicates that the port door is } \\
\text { raised to the "DOOR IN POSITION" } \\
\text { height } \\
\text { Verify that the register status is } \\
\text { recorded in the space provided. }\end{array}$ & $V$ & & $k$ \\
\hline 78 & $\begin{array}{l}\text { Press the "RETURN TO CURRENT SCREEN" button to return to the "PORT DO-07-203 MENU" at } \\
\text { 107-OIU-12-105B. }\end{array}$ & $\begin{array}{l}\text { Verify that the "PORT DO-07-203 } \\
\text { MENU" is displayed. }\end{array}$ & $\checkmark$ & & \\
\hline
\end{tabular}




\begin{tabular}{|c|c|c|c|c|c|}
\hline 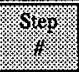 & TEST RROGEDURE STIESS & 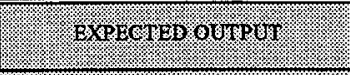 & 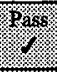 & fativ & (initivilu \\
\hline \multicolumn{6}{|c|}{ 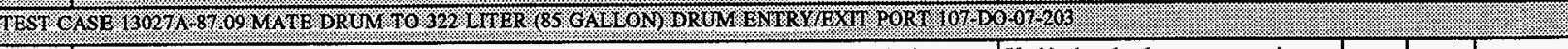 } \\
\hline 79 & $\begin{array}{l}\text { Because register ZS912B status has been unforced to permit position switch 07-ZS-912B to indicate } \\
\text { that the port door has reached the "DOOR IN POSTIION" height and the "SEQUENCE FAllED" } \\
\text { alarm has been cleared, the drum port opening sequence should continue. } \\
\text { The PCS should pulse energize solenoid valve 07-FEV-910N/O (Open) to pressurize the port door } \\
\text { open cylinders to vertically raise the door to the "open" position. }\end{array}$ & $\begin{array}{l}\text { Verify that the drum port opening } \\
\text { sequence continues. } \\
\text { Visually verify that the port door } \\
\text { rises to the "open" position. }\end{array}$ & J & & \\
\hline 80 & $\begin{array}{l}\text { Review the "PORT DO-07-203 MENU" status. A flashing "SEQUENCE FAIIED" message should } \\
\text { be displayed and the "ALARMS" button should be flashing. } \\
\text { Press the "ALARMS" button. The "LOCAL ALARMS" screen should be displayed, with a flashing } \\
\text { "DO-07-203 Failed to Open" alarm. } \\
\text { Press the "LOCAL ALARMS" screen to display the "LOCAL ALARMS" screen. Buttons should be } \\
\text { displayed near the bottom of the screen to allow alarms to be acknowledged. An active "DO-07-203 } \\
\text { Failed to Open" alarm should be displayed on this screen. }\end{array}$ & $\begin{array}{l}\text { Verify that a flashing "SEQUENCE } \\
\text { FAILED" message is displayed and } \\
\text { the "ALARMS" button is flashing. } \\
\text { Verify that the "LOCAL ALARMS" } \\
\text { screen is displayed with the active } \\
\text { alarm flashing. } \\
\text { Verify that the "LOCAL ALARMS" } \\
\text { screen with an active "DO-07-203 } \\
\text { Failed to Open" alarm is displayed. }\end{array}$ & 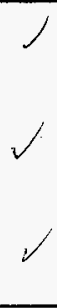 & & \\
\hline 81 & $\begin{array}{l}\text { Press the bottom area of the "LOCAL ALARMS" screen to activate the alarm selector feature. The } \\
\text { currently selected alarm should be highlighted. Press the up and down arrow buttons as needed to } \\
\text { select the appropriate alarm. } \\
\text { Press the "ACK" button to acknowledge the selected alarm. } \\
\text { Press the "DONE" button to return to the "LOCAL ALARMS" screen. }\end{array}$ & $\begin{array}{l}\text { Verify that the appropriate alarm is } \\
\text { selected (highlighted). } \\
\text { Verify that the selected alarm is } \\
\text { acknowledged. } \\
\text { Verify that the "LOCAL ALARMS" } \\
\text { screen is displayed and that the } \\
\text { acknowledged "DO-07-203 Failed to } \\
\text { Open" alarm is displayed on this } \\
\text { screen. }\end{array}$ & $\checkmark$ & & \\
\hline
\end{tabular}


HNF-SD-W026-ATR-021 Rev. 1

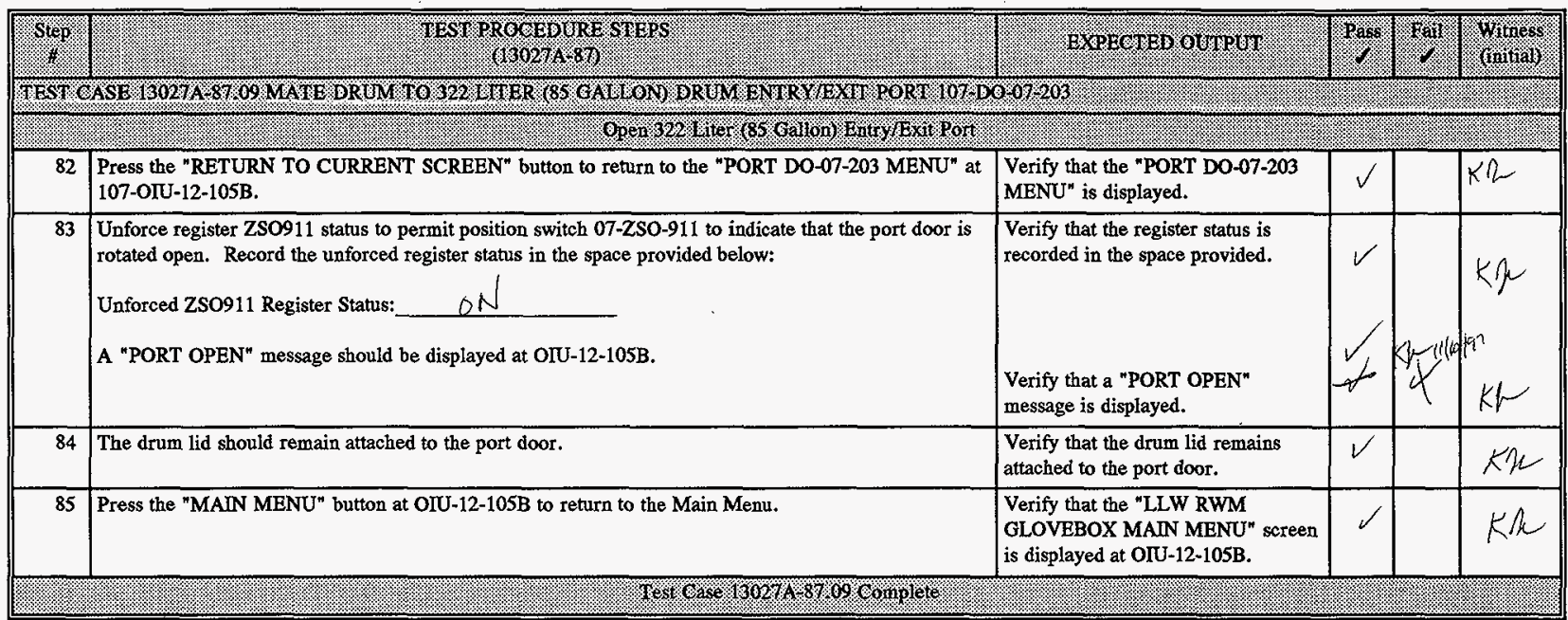




\begin{tabular}{|c|c|c|c|c|c|}
\hline Step & THST RRONED URE STIERS & 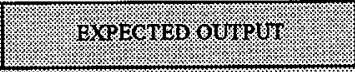 & Pas & Ifart & (rininging \\
\hline \multicolumn{6}{|c|}{ 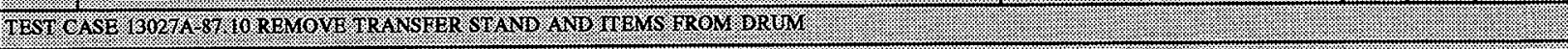 } \\
\hline & F. & & & & \\
\hline 1 & $\begin{array}{ll}\text { WARNING: } & \text { The "MATE DRUM TO BAGLESS TRANSFER PORT" test case is a prerequisite } \\
& \text { for this test case. Do not perform this test case unless the pre-requisite test case has } \\
\text { already been successfully completed. }\end{array}$ & $\begin{array}{l}\text { Verify that the "MATE DRUM TO } \\
\text { BAGLESS TRANSFER PORT" test } \\
\text { case has already been successfully } \\
\text { completed prior to running this test } \\
\text { case. }\end{array}$ & $V$ & & \\
\hline 2 & A Drath \& Schrader drum should be mated to the Bagless Transfer Port (107-D0-07-201). & $\begin{array}{l}\text { Verify that a Drath \& Schrader drum } \\
\text { is mated to the Bagless Transfer Port } \\
\text { (107-DO-07-201). }\end{array}$ & $\checkmark$ & & \\
\hline 3 & The Bagless Transfer Port door should be rotated completely open. & $\begin{array}{l}\text { Verify that the Bagless Transfer Port } \\
\text { is open. }\end{array}$ & $\sqrt{ }$ & & \\
\hline 4 & $\begin{array}{l}\text { The non-compliant item transfer stand should be contained in the Drath \& Schrader drum mated to the } \\
\text { Bagless Transfer Port (107-DO-07-201). }\end{array}$ & $\begin{array}{l}\text { Verify that the non-compliant item } \\
\text { transfer stand is inside the Drath \& } \\
\text { Schrader drum. }\end{array}$ & $V$ & & \\
\hline 5 & $\begin{array}{l}\text { NOTE: The hoist pendant 107-PC-07-009A "PENDANT SELECT" switch should have been turned to } \\
\text { the "PEND A" position during test procedure setup. This action should disable hoist pendant } \\
\text { 107-PC-07-009B. } \\
\text { Examine hoist pendant 107-PC-07-009B }\end{array}$ & $\begin{array}{l}\text { Verify that the "ENABLED" } \\
\text { indicator for hoist pendant 107-PC- } \\
\text { 07-009B is NOT illuminated. }\end{array}$ & $\checkmark$ & & \\
\hline 6 & $\begin{array}{l}\text { Activate the hoist pendant 107-PC-07-009B "LOWER" pushbutton to attempt to lower the hoist hook. } \\
\text { Because hoist pendant 107-PC-07-009B is not enabled, the hoist hook should not lower. }\end{array}$ & $\begin{array}{l}\text { Verify that the hoist hook does not } \\
\text { move when the hoist pendant 107- } \\
\text { PC-07-009B "LOWER" pushbutton } \\
\text { is activated. }\end{array}$ & $V$ & & \\
\hline 7 & $\begin{array}{l}\text { NOTE: The hoist trolley should have been centered over the Bagless Transfer Port (107-DO-07-201), } \\
\text { during test procedure setup. } \\
\text { The "LEFT" indicator on the control pendant should be illuminated, indicating that the hoist is over } \\
\text { the bagless transfer port. } \\
\text { Activate the Trolley/Hoist Pendant 107-PC-07-009A "LOWER" pushbutton to lower the grapple } \\
\text { assembly until it rests on the transfer stand. }\end{array}$ & $\begin{array}{l}\text { Verify that the "LEFT" indicator on } \\
\text { the control pendant is illuminated. } \\
\text { Verify that the grapple assembly is } \\
\text { resting on the transfer stand. }\end{array}$ & $\checkmark$ & & \\
\hline
\end{tabular}


HNF-SD-W026-ATR-021 Rev, 1

\begin{tabular}{|c|c|c|c|c|c|}
\hline Step & 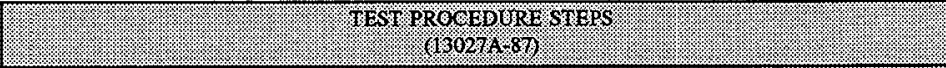 & (3. & rass. & 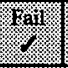 & (initivilu \\
\hline \multicolumn{6}{|c|}{ 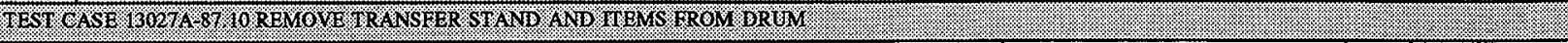 } \\
\hline 8 & $\begin{array}{l}\text { Activate the Trolley/Hoist Pendant 107-PC-07-009A "RAISE" pushbutton to raise the hoist until the } \\
\text { grapple assembly is verified to be firmly seated. }\end{array}$ & $\begin{array}{l}\text { Verify that the grapple assembly } \\
\text { hook is securely attached to the non- } \\
\text { compliant item transfer stand }\end{array}$ & $\checkmark$ & & \\
\hline 9 & $\begin{array}{l}\text { Activate the Trolley/Hoist Pendant 107-PC-07-009A "RAISE" pushbutton to raise the hoist with the } \\
\text { non-compliant item transfer stand until the transfer stand is positioned at least one foot above all items } \\
\text { in the transfer stand travel path. }\end{array}$ & $\begin{array}{l}\text { Visually verify that the hoist with the } \\
\text { non-compliant item transfer stand } \\
\text { rise out of the drum. } \\
\text { Verify that there is at least one foot } \\
\text { (approximately) of travel clearance } \\
\text { beneath the non-compliant item } \\
\text { transfer stand along the entire length } \\
\text { of the glovebox. }\end{array}$ & 灼 & & \\
\hline 10 & $\begin{array}{l}\text { NOTE: The Test Operator can control Trolley speed by way of three (3) position Left and Right } \\
\text { pushbuttons on the trolley/hoist Pendant. The operator should judge Trolley travel speed to } \\
\text { ensure safe operation. } \\
\text { Activate the Trolley/Hoist Pendant (107-PC-07-009A) Left/Right pushbuttons as needed to energize } \\
\text { trolley motor 107-CR-07-201/M1 (Trolley Traverse Drive) in reverse so that the trolley SLOWLY } \\
\text { travels the entire length of its travel path, and is positioned close to the } 322 \text { liter ( } 85 \text { gallon) Entry/Exit } \\
\text { Port. }\end{array}$ & $\begin{array}{l}\text { Verify that the trolley travels the } \\
\text { entire length of the trolley travel } \\
\text { path. }\end{array}$ & & & \\
\hline 11 & $\begin{array}{l}\text { Activate the Trolley/Hoist Pendant (107-PC-07-009A) Left/Right pushbuttons as needed to energize } \\
\text { trolley motor 107-CR-07-201/M1 (Trolley Traverse Drive) forward so that the trolley SLOWLY } \\
\text { moves to and is positioned over the } 208 \text { liter (55 gallon) Entry/Exit Port. (Port 202) }\end{array}$ & $\begin{array}{l}\text { Verify that the trolley is positioned } \\
\text { over the } 208 \text { liter ( } 55 \text { gallon) } \\
\text { Entry/Exit Port. (Port 202) }\end{array}$ & $\checkmark$ & & \\
\hline 12 & $\begin{array}{l}\text { Activate the Trolley/Hoist Pendant (107-PC-07-009A) Left/Right pushbuttons as needed to energize } \\
\text { trolley motor 107-CR-07-201/M1 (Trolley Traverse Drive) in reverse so that the trolley SLOWLY } \\
\text { moves to and is positioned adjacent to the } 322 \text { liter ( } 85 \text { gallon) Entry/Exit Port. (Port 203) }\end{array}$ & $\begin{array}{l}\text { Verify that the trolley is positioned } \\
\text { adjacent to the } 322 \text { liter (85 gallon) } \\
\text { Entry/Exit Port. (Port 203) }\end{array}$ & $V$ & & \\
\hline
\end{tabular}


HNF-SD-W026-ATR-021 Rev. 1

\begin{tabular}{|c|c|c|c|c|c|}
\hline Step? & IESIT PROCEOURT SIEPS & PXPECTEG OUT:Y & 19.8. & trat. & (nitivitil) \\
\hline \multicolumn{6}{|c|}{ 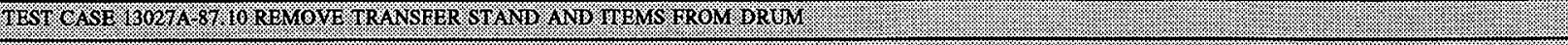 } \\
\hline \multicolumn{6}{|c|}{ 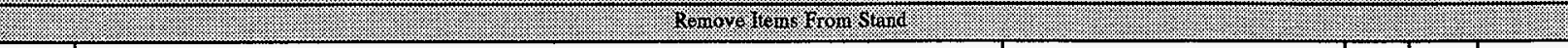 } \\
\hline 13 & $\begin{array}{l}\text { Confirm that the "LIW RWM GLOVEBOX MAIN MENU" screen is displayed at OIU-12-105B. If a } \\
\text { sub-menu is displayed, press the "MAIN MENU" button to return to the Main Menu. }\end{array}$ & $\begin{array}{l}\text { Verify that the "LLW RWM } \\
\text { GLOVEBOX MAIN MENU" screen } \\
\text { is displayed at OIU-12-105B. }\end{array}$ & $V$ & & \\
\hline 14 & $\begin{array}{l}\text { Press the "TRANSFER STAND MENU" from the "LLW RWM GLOVEBOX MAIN MENU" screen } \\
\text { at OIU-12-105B. }\end{array}$ & $\begin{array}{l}\text { Verify that the "TRANSFER } \\
\text { STAND MENU" screen is } \\
\text { displayed. }\end{array}$ & $\sqrt{ }$ & & \\
\hline 15 & $\begin{array}{l}\text { Press the "REMOVE ITEMS" button from the "TRANSFER STAND MENU" screen at OIU-12- } \\
\text { 105B. } \\
\text { A "REMOVAL OF ITEMS IN PROGRESS..." message should be displayed on the "TRANSFER } \\
\text { STAND MENU" screen at OIU-12-105B. } \\
\text { The "REMOVE ITEMS" button notifies the PCS that the bar code labels that will be read using bar } \\
\text { code scanner 107-NE-12-314 correspond to items that are being removed from the transfer stand for } \\
\text { processing. }\end{array}$ & $\begin{array}{l}\text { Verify that the "TRANSFER } \\
\text { STAND MENU" screen is } \\
\text { displayed. } \\
\text { Verify that the "REMOVAL OF } \\
\text { ITEMS IN PROGRESS..." message } \\
\text { is displayed on the "TRANSFER } \\
\text { STAND MENU" screen at OIU-12- } \\
\text { 105B. }\end{array}$ & $V$ & & \\
\hline 16 & $\begin{array}{l}\text { Press the "END REMOVE" button from the "TRANSFER STAND MENU" screen at OIU-12-105B. } \\
\text { A "REMOVAL OF ITEMS COMPLETE" message should be displayed on the "TRANSFER STAND } \\
\text { MENU" screen at OIU-12-105B. }\end{array}$ & $\begin{array}{l}\text { Verify that the "TRANSFER } \\
\text { STAND MENU" screen is } \\
\text { displayed. } \\
\text { Verify that the "REMOVAL OF } \\
\text { ITEMS COMPLETE" message is } \\
\text { displayed on the "TRANSFER } \\
\text { STAND MENU" screen at OIU-12- } \\
\text { 105B. }\end{array}$ & $\checkmark$ & & \\
\hline
\end{tabular}


HNF-SD-W026-ATR-021 Rev. 1

\begin{tabular}{|c|c|c|c|c|c|}
\hline Step: & TESI PROCEDURE STERS & 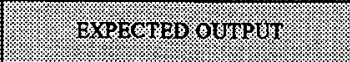 & \% & (6. & \\
\hline \multicolumn{6}{|c|}{ 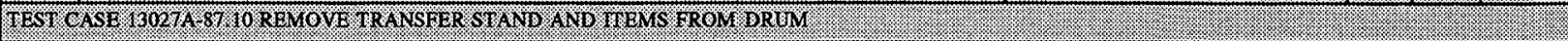 } \\
\hline \multicolumn{6}{|c|}{ il } \\
\hline 17 & $\begin{array}{l}\text { Press the "ADD ITEMS" button from the "TRANSFER STAND MENU" screen at OIU-12-105B. } \\
\text { An "ADD ITEMS IN PROGRESS..." message should be displayed on the "TRANSFER STAND } \\
\text { MENU" screen at OIU-12-105B. } \\
\text { The "ADD ITEMS" button notifies the PCS that the bar code labels that will be read using bar code } \\
\text { scanner 107-NE-12-314 correspond to items that are being added to the transfer stand for removal from } \\
\text { the glovebox. }\end{array}$ & $\begin{array}{l}\text { Verify that the "TRANSFER } \\
\text { STAND MENU" screen is } \\
\text { displayed. } \\
\text { Verify that the "ADD ITEMS IN } \\
\text { PROGRESS..." message is displayed } \\
\text { On the "TRANSFER STAND } \\
\text { MENU" screen at OIU-12-105B. }\end{array}$ & 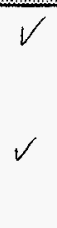 & & \\
\hline 18 & $\begin{array}{l}\text { NOTE: Because the "NON-COMPLIANT PACKET" will be used to test treated item loadout and will } \\
\text { be used in other test cases, it is not returned to the transfer stand in this test case. } \\
\text { Press the "END ADD" button from the "TRANSFER STAND MENU" screen at OIU-12-105B. } \\
\text { An "ADD ITEMS COMPLETE" message should be displayed on the "TRANSFER STAND MENU" } \\
\text { screen at OIU-12-105B. }\end{array}$ & $\begin{array}{l}\text { Verify that the "TRANSFER } \\
\text { STAND MENU" screen is } \\
\text { displayed. } \\
\text { Verify that the "ADD ITEMS } \\
\text { COMPLETE" message is displayed } \\
\text { on the "TRANSFER STAND } \\
\text { MENU" screen at OIU-12-105B. }\end{array}$ & $\checkmark$ & & \\
\hline
\end{tabular}


FANF-SD-W026-ATR-021 Rev. 1

\begin{tabular}{|c|c|c|c|c|c|}
\hline Sitep & TEST P ROCEDIR STEPS & 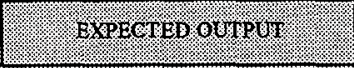 & Pass & Iar & 1) \\
\hline \multicolumn{6}{|c|}{ 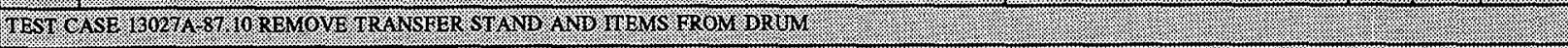 } \\
\hline \multicolumn{6}{|c|}{ (2. } \\
\hline 19 & Press the "MAIN MENU" button from the "TRANSFER STAND MENU" screen at OIU-12-105B. & $\begin{array}{l}\text { Verify that the "LLW RWM } \\
\text { GLOVEBOX MAIN MENU" screen } \\
\text { is displayed at OIU-12-105B. }\end{array}$ & $V$ & & \\
\hline 20 & $\begin{array}{l}\text { Press the "TREATED ITEM" } 6 \text { utton from the "LLW RWM GLOVEBOX MAIN MENU" screen at } \\
\text { OIU-12-10SB. }\end{array}$ & $\begin{array}{l}\text { Verify that the "TREATED ITEM } \\
\text { MENU" screen is displayed at OIU- } \\
12-105 B \text {. }\end{array}$ & & & \\
\hline 21 & $\begin{array}{l}\text { Press the "LOADOUT TREATED ITEMS" button from the "TREATED ITEM MENU" screen at } \\
\text { OIU-12-105B. } \\
\text { A "TREATED ITEM LOADOUT IN PROGRESS..." message should be displayed on the "TREATED } \\
\text { ITEM MENU" screen at OIU-12-105B. } \\
\text { The "LOADOUT TREATED ITEMS" button notifies the PCS that the bar code labels that will be read } \\
\text { using bar code scanner 107-NE-12-315 correspond to items that are being added to an Entry/Exit drum } \\
\text { for removal from the glovebox as "compliant items". }\end{array}$ & $\begin{array}{l}\text { Verify that a "TREATED ITEM } \\
\text { LOADOUT IN PROGRESS..." } \\
\text { message is displayed on the } \\
\text { "TREATED ITEM MENU" screen } \\
\text { at OIU-12-105B. }\end{array}$ & & & \\
\hline 22 & $\begin{array}{l}\text { Press the "END TREATED ITEM LOADOUT" button from the "TREATED ITEM MENU" screen at } \\
\text { OIU-12-105B. } \\
\text { A "TREATED ITEM LOADOUT COMPLETE" message should be displayed on the "TREATED } \\
\text { ITEM MENU" screen at OIU-12-105B. }\end{array}$ & $\begin{array}{l}\text { Verify that the "TREATED ITEM } \\
\text { MENU" screen is displayed. } \\
\text { Verify that the "TREATED ITEM } \\
\text { LOADOUT COMPLETE" message } \\
\text { is displayed on the "TREATED } \\
\text { ITEM MENU" screen at OIU-12- } \\
\text { 105B }\end{array}$ & & & \\
\hline & 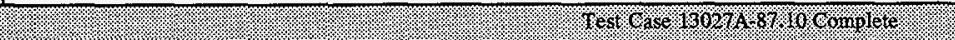 & & & & \\
\hline
\end{tabular}


HNF-SD-W026-ATR-021 Rev. 1

\begin{tabular}{|c|c|c|c|c|c|}
\hline Sis. & 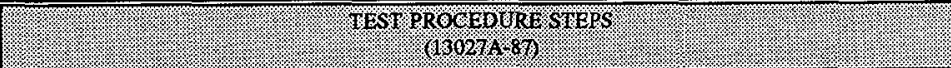 & 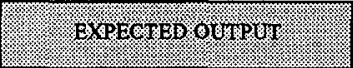 & Passons & wan & Whing \\
\hline \multicolumn{6}{|c|}{ 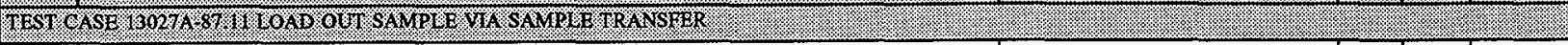 } \\
\hline 1 & $\begin{array}{l}\text { Confirm that the "LLW RWM GLOVEBOX MAIN MENU" screen is displayed at ONU-12-105B. If a } \\
\text { sub-menu is displayed, press the "MAIN MENU" button to return to the Main Menu. }\end{array}$ & $\begin{array}{l}\text { Verify that the "LLW RWM } \\
\text { GLOVEBOX MAIN MENU" screen } \\
\text { is displayed at OIU-12-10SB. }\end{array}$ & $\checkmark$ & & \\
\hline 2 & 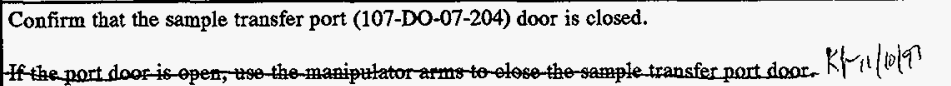 & $\begin{array}{l}\text { Verify that the sample transfer port } \\
\text { is closed. }\end{array}$ & $\checkmark$ & & \\
\hline 3 & $\begin{array}{l}\text { From outside of the glovebox, remove the port safety cover. } \\
\text { ERTUNESUS STEP }\end{array}$ & $\begin{array}{l}\text { Verify that the port safety cover is } \\
\text { removed. }\end{array}$ & X & & \\
\hline 4 & $\begin{array}{l}\text { NOTE: A sample canister, as noted during setup, should be available to support testing. } \\
\text { Align the sample canister to the sealed cell flange. } \\
\text { Orient the canister locking bayonets with the openings on the cell flange. } \\
\text { Rotate the canister clockwise } 60 \text { degrees. }\end{array}$ & $\begin{array}{l}\text { Verify that the sample canister } \\
\text { rotates smoothly. } \\
\text { Verify the sample canister locks and } \\
\text { seals to the cell flange. } \\
\text { Verify that the canister cover unlocks } \\
\text { from the canister, and locks and } \\
\text { seals to the cell port. }\end{array}$ & $\mathscr{\gamma}$ & & \\
\hline 5 & $\begin{array}{l}\text { Press the "SAMPLE MENU" from the "LLW RWM GLOVEBOX MAIN MENU" screen at OIU-12- } \\
\text { 105B. } \\
\text { Both "LOADOUT SAMPLES" and "END SAMPLE LOADOUT" buttons should be displayed. }\end{array}$ & $\begin{array}{l}\text { Verify that the "SAMPLE MENU" } \\
\text { screen is displayed at OIU-12-105B. } \\
\text { Verify that "LOADOUT SAMPLES" } \\
\text { and "END SAMPLE LOADOUT" } \\
\text { buttons are displayed. }\end{array}$ & $\checkmark$ & & Kffe \\
\hline 6 & $\begin{array}{l}\text { Press the "LOADOUT SAMPLES" button from the "SAMPLE MENU" at OIU-12-105B. } \\
\text { A "SAMPLE LOADOUT IN PROGRESS..." message should be displayed on the "SAMPLE MENU" } \\
\text { at OIU-12-105B. } \\
\text { The selection of the "LOADOUT SAMPLES" button notifies the PCS that bar coded items read at } \\
\text { fixed scanner 107-NE-12-314 are samples that are being removed from the glovebox. }\end{array}$ & $\begin{array}{l}\text { Verify that the "SAMPLE MENU" } \\
\text { screen is displayed at OIU-12-105B. } \\
\text { Verify that a "SAMPLE LOADOUT } \\
\text { IN PROGRESS..." message is } \\
\text { displayed. }\end{array}$ & $\checkmark$ & & $k \notin$ \\
\hline 7 & Open the sample transfer port (107-D0-07-204) hinged double door inside the glovebox. & $\begin{array}{l}\text { Verify that the hinged double door } \\
\text { opens fully and smoothly. }\end{array}$ & $\checkmark$ & & \\
\hline
\end{tabular}


HNF-SD-W026-ATR-021 Rev, 1

\begin{tabular}{|c|c|c|c|c|c|}
\hline step & (1. & 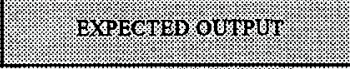 & ?. & 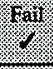 & (rinitalis \\
\hline \multicolumn{6}{|c|}{ 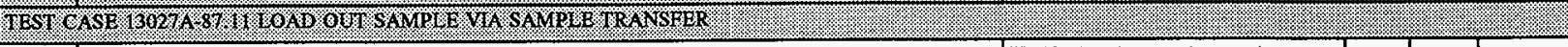 } \\
\hline 8 & $\begin{array}{l}\text { Transfer the available sample container to the sample canister through the open double door and close } \\
\text { the double door. }\end{array}$ & $\begin{array}{l}\text { Verify that the sample container was } \\
\text { transferred into the sample canister. } \\
\text { Verify that the hinged double door is } \\
\text { closed. }\end{array}$ & $\checkmark$ & & \\
\hline 9 & $\begin{array}{l}\text { Press the "END SAMPLE LOADOUT" button from the "SAMPLE MENU" at OIU-12-105B. } \\
\text { A "SAMPLE LOADOUT COMPLETE" message should be displayed on the "SAMPLE MENU" at } \\
\text { OIU-12-105B. } \\
\text { The selection of the "END SAMPLE LOADOUT" button notifies the sample loadout process is } \\
\text { complete. }\end{array}$ & $\begin{array}{l}\text { Verify that a "SAMPLE LOADOUT } \\
\text { COMPLETE" message is displayed } \\
\text { on the "SAMPLE MENU" screen at } \\
\text { OrU-12-105B. }\end{array}$ & I & & $K_{G j}$ \\
\hline 10 & From outside the glovebox, rotate the sample canister counterclockwise 60 degrees. & $\begin{array}{l}\text { Verify that the sample canister } \\
\text { rotates smoothly. } \\
\text { Verify the cover unlocks from the } \\
\text { cell port and locks and seals to the } \\
\text { canister. } \\
\text { Verify that the canister unlocks from } \\
\text { the cell flange. }\end{array}$ & $V$ & & xl) \\
\hline 11 & From outside the glovebox, disengage the sample canister from the cell flange. & $\begin{array}{l}\text { Verify that the sample canister is } \\
\text { disengaged from the cell flange. }\end{array}$ & $\checkmark$ & & $K g$ \\
\hline 12 & Reinstall the port safety cover on the cell flange GRRONEOUS STEP & $\begin{array}{l}\text { Verify the port safety cover is } \\
\text { properly installed. }\end{array}$ & & & \\
\hline & 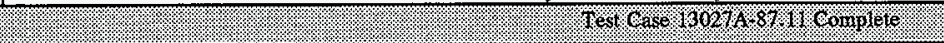 & & & & \\
\hline
\end{tabular}




\begin{tabular}{|c|c|c|c|c|c|c|}
\hline Sitep & & 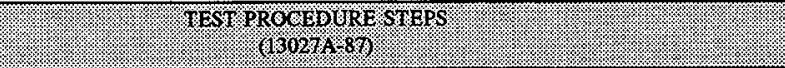 & RXPECTEQ OU⿴囗十) & pas. & raif & (nitivi) \\
\hline \multicolumn{7}{|c|}{ 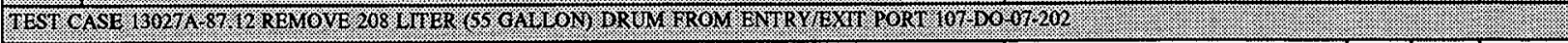 } \\
\hline 1 & WARNING: & $\begin{array}{l}\text { The "MATE DRUM TO } 208 \text { LITER (55 GALLON) ENTRY/EXIT PORT 107-DO- } \\
07-202 \text { " test case is a prerequisite for this test case. Do not perform this test case } \\
\text { unless the pre-requisite test cases have already been successfully completed. }\end{array}$ & $\begin{array}{l}\text { Verify that the "MATE DRUM TO } \\
\text { 208 LITER (55 GALLON) } \\
\text { ENTRY/EXIT PORT 107-DO-07- } \\
202 \text { " test case has already been } \\
\text { successfully completed prior to } \\
\text { running this test case. }\end{array}$ & $V$ & & \\
\hline 2 & CAUTION: & $\begin{array}{l}\text { The following sequence of test procedure steps involve automatic port door closing, } \\
\text { controlled by LCU } 102 \text { (Referred to as the "PCS" in this test procedure). These test } \\
\text { procedure steps should be carefully reviewed to permit rapid verification of test } \\
\text { conditions during the automatic port opening sequence. }\end{array}$ & $\begin{array}{l}\text { Verify that the remaining test } \\
\text { procedure steps in this test case are } \\
\text { carefully reviewed prior to } \\
\text { completing this test case. }\end{array}$ & $\sqrt{ }$ & & \\
\hline 3 & \multicolumn{2}{|c|}{$\begin{array}{l}\text { Confirm that the "LLW RWM GLOVEBOX MAIN MENU" screen is displayed at OIU-12-105B. If a } \\
\text { sub-menu is displayed, press the "MAIN MENU" button to return to the Main Menu. }\end{array}$} & $\begin{array}{l}\text { Verify that the "LLW RWM } \\
\text { GLOVEBOX MAIN MENU" screen } \\
\text { is displayed at OIU-12-105B. }\end{array}$ & $\checkmark$ & & \\
\hline 4 & \multicolumn{2}{|c|}{$\begin{array}{l}\text { Confirm that the Entry/Exit Port (107-DO-07-202) door is rotated open and that a drum is mated to the } \\
\text { port. }\end{array}$} & $\begin{array}{l}\text { Visually verify that the Entry/Exit } \\
\text { Port (107-DO-07-202) door is rotated } \\
\text { open and that a drum is mated to the } \\
\text { port. VERIFY } \angle T .201 E \text { in Normel }\end{array}$ & det & 10197 & \\
\hline 5 & \multicolumn{2}{|c|}{$\begin{array}{l}\text { Confirm that no items are present that would prevent the Entry/Exit Port (107-DO-07-202) from } \\
\text { properly closing. }\end{array}$} & $\begin{array}{l}\text { Visually verify that no items are } \\
\text { present that would prevent the } \\
\text { Entry/Exit Port (107-DO-07-202) } \\
\text { from properly closing. }\end{array}$ & $\checkmark$ & & \\
\hline$\overline{6}$ & \multicolumn{2}{|c|}{$\begin{array}{l}\text { Force the status of position switch 07-ZSC-909 register ZSC909 (Entry/Exit Port 107-DO-07-202) to } \\
\text { not activated to indicate that the port door is not rotated closed. Record the register status in the space } \\
\text { provided below. } \\
\text { Register Forced Status } \\
\text { ZSC909 Method of Confirmation } \\
\text { The door rotated closed position switch functions as an interlock for the Entry/Exit Port. The drum } \\
\text { exit sequence should not proceed until the position switch is activated. }\end{array}$} & $\begin{array}{l}\text { Verify that register ZSC909 is forced } \\
\text { not activated. }\end{array}$ & $\checkmark$ & & \\
\hline
\end{tabular}




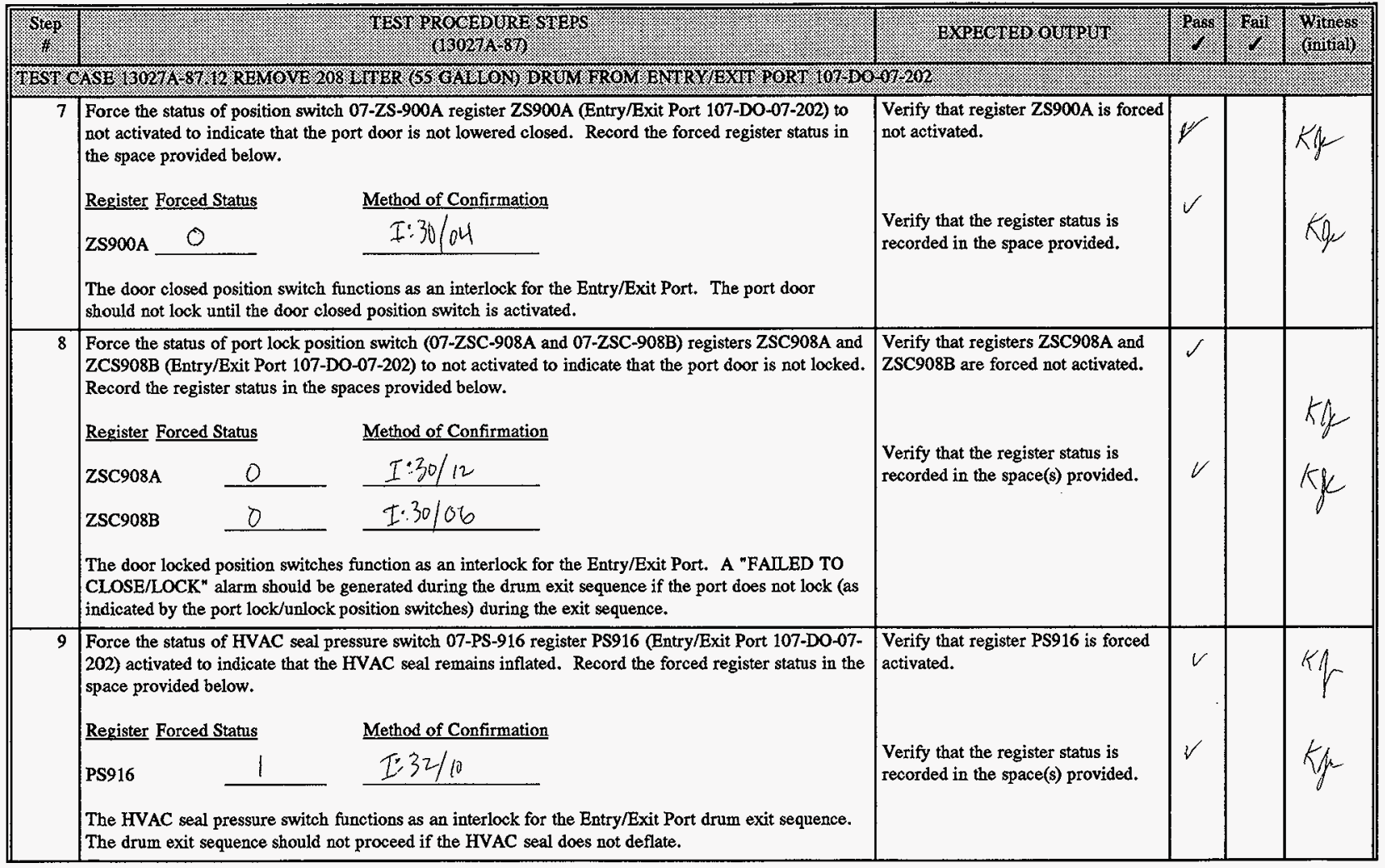


HINF-SD-W026-ATR-021 Rev. 1

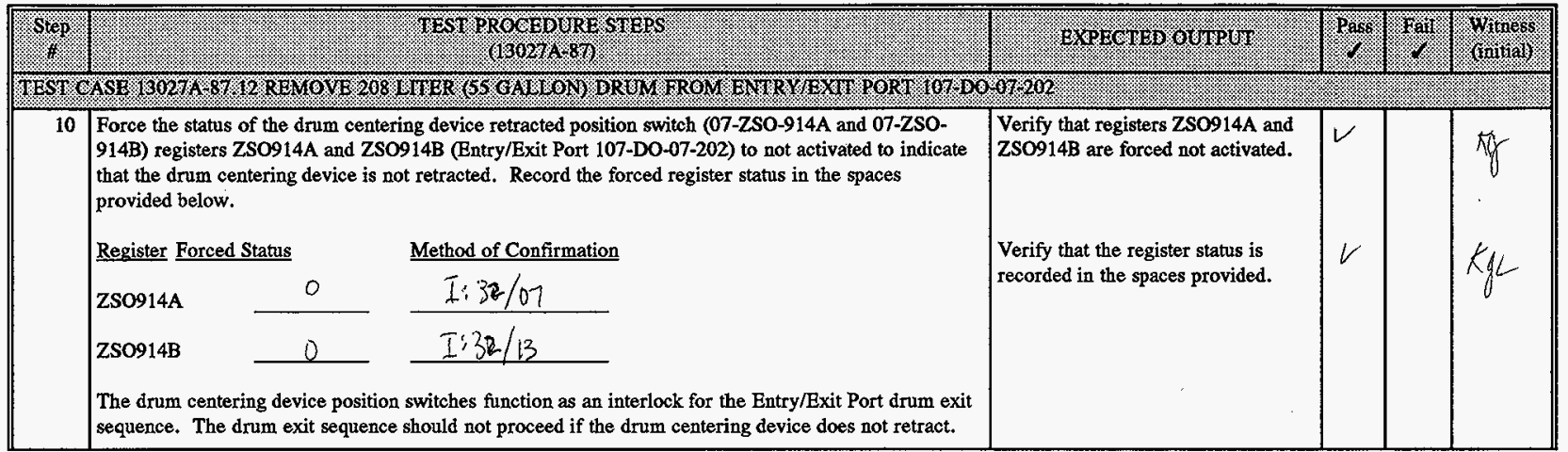


HNF-SD-W026-ATR-021 Rev, 1

\begin{tabular}{|c|c|c|c|c|c|}
\hline step & $\begin{array}{l}\text { TEST PROCLOURO STEPS } \\
.\end{array}$ & 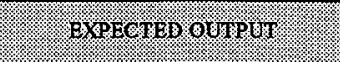 & Pass & 6. & (initial) \\
\hline \multicolumn{6}{|c|}{ 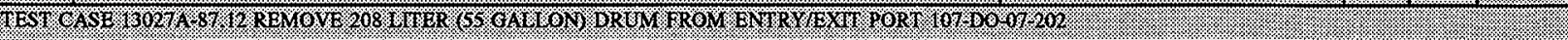 } \\
\hline \multicolumn{6}{|c|}{ 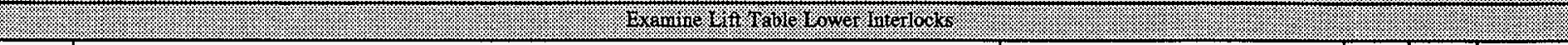 } \\
\hline 11 & $\begin{array}{l}\text { Attempt to move the } 208 \text { liter ( } 55 \text { gallon) Entry/Exit Port lift table (107-LT-09-201E) by activating the } \\
\text { lift table "LOWER" pustbutton at the lift table local control pedestal (107-PC-09-201E). } \\
\text { The Entry/Exit Port should be open with a drum mated to this port. Because the port is not closed and } \\
\text { locked, the "LOWER" pushbutton at the lift table local control pedestal should be disabled and have no } \\
\text { effect on the lift table. }\end{array}$ & $\begin{array}{l}\text { Verify that activating the "LOWER" } \\
\text { pushbutton has no effect on the lift } \\
\text { table. }\end{array}$ & $\checkmark$ & & $x / \rho$ \\
\hline 12 & $\begin{array}{l}\text { Attempt to move the Lift Table (107-LT-09-201E) roller conveyors by activating the lift table } \\
\text { "FORWARD" and "REVERSE" pushbuttons at the lift table local control pedestal (107-PC-09-201E). } \\
\text { Because the lift table is not lowered, activating the "FORWARD" and "REVERSE" pushbuttons at the } \\
\text { lift table local control pedestal (107-PC-09-201E) should be disabled and have no effect on the lift } \\
\text { table. }\end{array}$ & $\begin{array}{l}\text { Verify that activating the } \\
\text { "FORWARD" and "REVERSE" } \\
\text { pushbuttons has no effect on the lift } \\
\text { table. }\end{array}$ & $\checkmark$ & & $K()^{2}$ \\
\hline
\end{tabular}


HNF-SD-W026-ATR-021 Rev. 1

\begin{tabular}{|c|c|c|c|c|c|}
\hline Step: & TEST PROQEDURTF STEPS & EXPECTED OUTPUI & (2). & 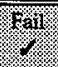 & (rinitaly \\
\hline \multicolumn{6}{|c|}{ 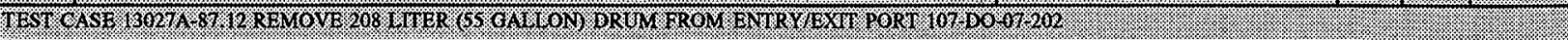 } \\
\hline \multicolumn{6}{|c|}{ 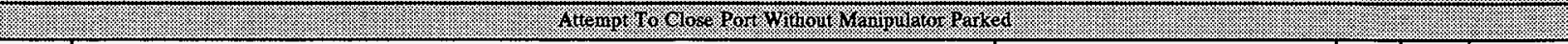 } \\
\hline 13 & $\begin{array}{l}\text { NOTE: The manipulator serves as an interlock for Entry/Exit Port operation. When the manipulator } \\
\text { is not at the park position, the Entry/Exit Port should not be able to close. The manipulator } \\
\text { is initially slightly displaced from the park position to allow this interlock to be tested. } \\
\text { Place the LLW RWM Waste Manipulator (107-EM-07-201) approximately one foot from park position } \\
2 \text { (farthest from Bagless Transfer Port (107-D0-07-201) with both manipulator arms fully parked. }\end{array}$ & $\begin{array}{l}\text { Visually verify that the waste } \\
\text { manipulator is approximately one } \\
\text { foot away park position } 2 \text { with both } \\
\text { arms parked. }\end{array}$ & $\sqrt{ }$ & & KQ \\
\hline 14 & $\begin{array}{l}\text { Press the "CLOSE PORT" button from the "PORT DO-07-202 MENU" screen at OIU-12-105B. } \\
\text { Because the manipulator is not parked, the port (107-DO-07-202) should not close. }\end{array}$ & $\begin{array}{l}\text { Verify that the port door does not } \\
\text { rotate closed. } \\
\text { Verify that a "PORT CLOSING..." } \\
\text { message is not displayed at OIU-12- } \\
105 B \text {. }\end{array}$ & $\sqrt{ }$ & & \\
\hline 15 & $\begin{array}{l}\text { Place the LLW RWM Waste Manipulator (107-EM-07-201) at park position } 2 \text { (farthest from Bagless } \\
\text { Transfer Port (107-DO-07-201) with both manipulator arms fully parked. }\end{array}$ & $\begin{array}{l}\text { Visually verify that the waste } \\
\text { manipulator is at park position } 2 \text { with } \\
\text { both arms parked. }\end{array}$ & $\checkmark$ & & Kh \\
\hline
\end{tabular}


HNF-SD-W026-ATPr021 Rev. 1

\begin{tabular}{|c|c|c|c|c|c|}
\hline siter & TEST PRG QEDURE STERS & EXPECTED OUYTIT) & Par & 6.8. & (initivess) \\
\hline \multicolumn{6}{|c|}{ 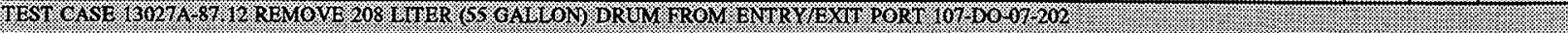 } \\
\hline \multicolumn{6}{|c|}{ 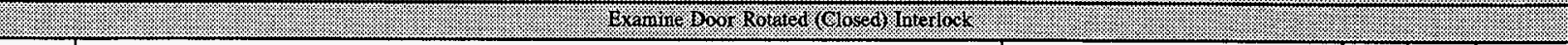 } \\
\hline 16 & $\begin{array}{l}\text { Press the "PORT DO-07-202 MENU" button from the "LLW RWM GLOVEBOX MAIN MENU" } \\
\text { screen at OIU-12-105B. }\end{array}$ & $\begin{array}{l}\text { Verify that the "PORT DO-07-202 } \\
\text { MENU" screen is displayed. }\end{array}$ & $\checkmark$ & & \\
\hline 17 & Press the "CLOSE PORT" button from the PORT DO-07-202 Menu at OIU-12-105B. & $\begin{array}{l}\text { Verify that a "PORT CLOSING..." } \\
\text { message is displayed at OIU-12- } \\
\text { 105B. }\end{array}$ & $\checkmark$ & & \\
\hline 18 & $\begin{array}{l}\text { The PCS should pulse activate solenoid valve 07-FEV-910K/C (Close) to pressurize the door rotation } \\
\text { cylinder to move the port door to the rotated closed position. } \\
\text { The "Door Closed" position switch (07-ZSC-909) register ZSC909 should be remain forced not } \\
\text { activated when the door is fully rotated. }\end{array}$ & $\begin{array}{l}\text { Verify that the port door rotates } \\
\text { closed. } \\
\text { Verify that the port door rotated } \\
\text { closed position switch } 07-Z S C-909 \\
\text { register ZSC } 909 \text { remains forced not } \\
\text { activated. }\end{array}$ & & & \\
\hline 19 & $\begin{array}{l}\text { The door rotated closed position switch functions as an interlock for the Entry/Exit Port. The drum } \\
\text { exit sequence should not proceed to lower the port door closed until the "Door Closed" position switch } \\
\text { is activated. } \\
\text { Wait } 2 \text { minutes. }\end{array}$ & $\begin{array}{l}\text { Verify that the port door does not } \\
\text { lower closed during the } 2 \text { minute } \\
\text { waiting period. }\end{array}$ & $V$ & & \\
\hline 20 & $\begin{array}{l}\text { Unforce register ZSC909 (Entry/Exit Port 107-DO-07-202) to allow position switch 07-ZSC-909 to } \\
\text { indicate that the port door is rotated closed. Record the unforced register status in the space provided } \\
\text { below. } \\
\text { Unforced ZSC909 Register Status: }\end{array}$ & $\begin{array}{l}\text { Verify that register ZSC909 is } \\
\text { unforced. } \\
\text { Verify that the register status is } \\
\text { recorded in the space provided. }\end{array}$ & $W$ & & KR \\
\hline
\end{tabular}


HNF-SD-W026-ATR-021 Rev. 1

\begin{tabular}{|c|c|c|c|c|c|}
\hline stis. & YEST PROQEDURF STERS & 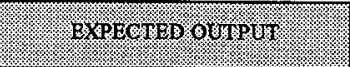 & Pas. & ratil: & Wininess \\
\hline \multicolumn{6}{|c|}{ 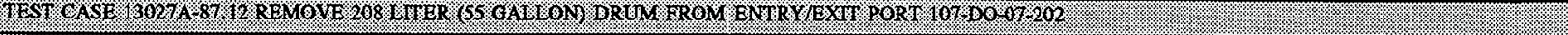 } \\
\hline \multicolumn{6}{|c|}{ 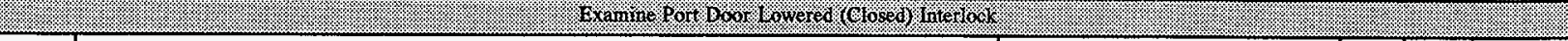 } \\
\hline 21 & $\begin{array}{l}\text { Because the port door is rotated closed, position switch } 07-Z \text { SC-909 should be activated, indicating that } \\
\text { the door is rotated closed and the sequence should continue. } \\
\text { After position switch } 07-\text { ZSC-909 indicates that the port door is rotated closed, the PCS should pulse } \\
\text { energize solenoid valve 07-FEV-9100/C (Close) to lower the port door closed. }\end{array}$ & $\begin{array}{l}\text { Verify that the port (107-DO-07-202) } \\
\text { door lowers closed. }\end{array}$ & $\checkmark$ & & \\
\hline 22 & 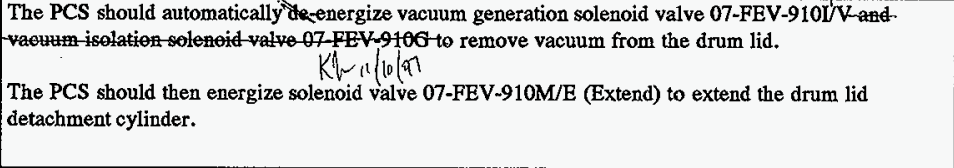 & 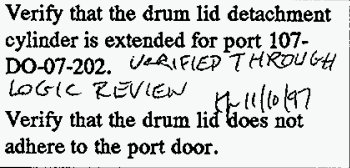 & $V$ & & \\
\hline 23 & $\begin{array}{l}\text { The PCS should automatically energize the lift table motor 107-LT-09-201E/M1 to lower the lift table } \\
\text { to "Drum Centering" height. }\end{array}$ & $\begin{array}{l}\text { Verify that the lift table lowers to } \\
\text { "Drum Centering" height. } \\
\text { Verify that the port door lowers to } \\
\text { the "closed" position. }\end{array}$ & $\mathscr{U}$ & & \\
\hline 24 & $\begin{array}{l}\text { The door lowered closed position switch functions as an interlock for the Entry/Exit Port. The port } \\
\text { door should not lock until the door lowered closed position switch } 07-Z S-900 \mathrm{~A} \text { is activated. } \\
\text { Wait } 2 \text { minutes. }\end{array}$ & $\begin{array}{l}\text { Verify that the port door locking } \\
\text { cylinders do not extend during the } \\
\text { two (2) minute waiting period. }\end{array}$ & $V$ & & \\
\hline 25 & $\begin{array}{l}\text { Unforce the status of position switch 07-ZS-900A (Entry/Exit Port 107-DO-07-202) to allow this } \\
\text { switch to indicate that the port door is lowered closed. Record the unforced register status in the space } \\
\text { provided below. } \\
\text { Unforced ZS900A Register Status: }\end{array}$ & $\begin{array}{l}\text { Verify that register ZS900A is } \\
\text { unforced. } \\
\text { Verify that the register status is } \\
\text { recorded in the space provided. }\end{array}$ & $\checkmark$ & & $k / h$ \\
\hline
\end{tabular}


HNF-SD-W026-ATR-021 Rev. 1

\begin{tabular}{|c|c|c|c|c|c|}
\hline Siep & 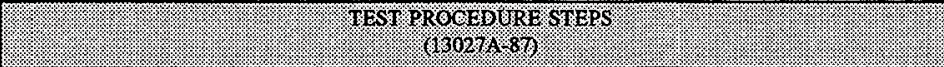 & 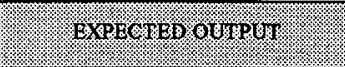 & Yass: & I. & (rowitial) \\
\hline \multicolumn{6}{|c|}{ 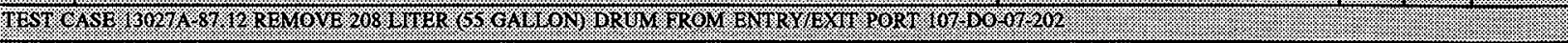 } \\
\hline & 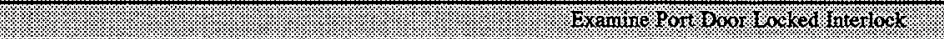 & & & & \\
\hline 26 & $\begin{array}{l}\text { When position switch 07-ZS-900A status is unforced, this switch should correctly indicate the position } \\
\text { of the port door. } \\
\text { Because the PCS has lowered the lift table to "Drum Centering" height, the port door should be } \\
\text { completely lowered and position switch } 07-Z S-900 \mathrm{~A} \text { should be activated, indicating that the port door } \\
\text { is lowered closed. } \\
\text { After position switch 07-ZS-900A is activated, the PCS should energize solenoid valve 07-FEV-910J/L } \\
\text { (Lock) to extend the port door locking cylinders. }\end{array}$ & $\begin{array}{l}\text { Verify that the port door locking } \\
\text { cylinders fully extend to lock the } \\
\text { port door. }\end{array}$ & $\sqrt{ }$ & & Kh \\
\hline 27 & $\begin{array}{l}\text { The door locked position switches 07-ZSC-908A and 07-ZSC-908A function as an interlock for the } \\
\text { Entry/Exit Port. The drum exit sequence should stop if the door locked position switches are not } \\
\text { activated. } \\
\text { Wait } 2 \text { minutes. }\end{array}$ & $\begin{array}{l}\text { Verify that the drum lid detachment } \\
\text { cylinder does not retract during the } \\
\text { two (2) minute waiting period. }\end{array}$ & $V$ & & L \\
\hline 28 & $\begin{array}{l}\text { Review the "PORT DO-07-202 MENU" status. A flashing "SEQUENCE FAILED" message should } \\
\text { be displayed and the "ALARMS" button should be flashing. } \\
\text { Press the "ALARMS" button. The "LOCAL ALARMS" screen should be displayed, with a flashing } \\
\text { "DO-07-202 Failed to Close and Lock" alarm. } \\
\text { Press the "LOCAL ALARMS" screen to display the "LOCAL ALARMS" screen. Buttons should be } \\
\text { displayed near the bottom of the screen to allow alarms to be acknowledged. An active "DO-07-202 } \\
\text { Failed to Close and Lock" alarm should be displayed on this screen. }\end{array}$ & $\begin{array}{l}\text { Verify that a flashing "SEQUENCE } \\
\text { FAILED" message is displayed and } \\
\text { the "ALARMS" button is flashing. } \\
\text { Verify that the "LOCAL ALARMS" } \\
\text { screen is displayed with the active } \\
\text { alarm flashing. } \\
\text { Verify that the "LOCAL ALARMS" } \\
\text { screen with an active "DO-07-202 } \\
\text { Failed to Close and Lock" alarm is } \\
\text { displayed. }\end{array}$ & $\checkmark$ & & $k 2 m$ \\
\hline
\end{tabular}


HNF-SD-W026-ATR-021 Rev. 1

\begin{tabular}{|c|c|c|c|c|c|}
\hline Step. & 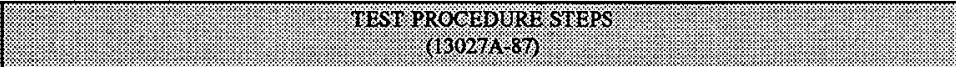 & BXPECTESYOUTPET & (1960) & (Fin. & (rinitivil) \\
\hline \multicolumn{6}{|c|}{ 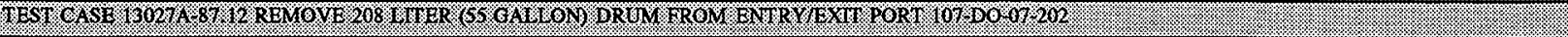 } \\
\hline 29 & $\begin{array}{l}\text { Press the bottom area of the "LOCAL ALARMS" screen to activate the alarm selector feature. The } \\
\text { currently selected alarm should be highlighted. Press the up and down arrow buttons as needed to } \\
\text { select the appropriate alarm. } \\
\text { Press the "ACK" button to acknowledge the selected alarm. } \\
\text { Press the "DONE" button to return to the "LOCAL ALARMS" screen. }\end{array}$ & $\begin{array}{l}\text { Verify that the appropriate alarm is } \\
\text { selected (hightighted). } \\
\text { Verify that the selected alarm is } \\
\text { acknowledged. } \\
\text { Verify that the "LOCAL ALARMS" } \\
\text { screen is displayed and that the } \\
\text { acknowledged "DO-07-202 Failed to } \\
\text { Close and Lock" alarm is displayed } \\
\text { on this screen. }\end{array}$ & $\checkmark$ & & $k 2$ \\
\hline 30 & $\begin{array}{l}\text { Unforce the status of door locked position switch (07-ZS-908A and 07-ZS-908B) registers ZSC908A } \\
\text { and ZSC908B (Entry/Exit Port 107-DO-07-202) to allow these switches to indicate that the port door is } \\
\text { locked. Record the unforced register status in the space provided below. } \\
\text { Unforced ZSC908A Register Status: } \\
\text { Unforced ZSC908B Register Status: }\end{array}$ & $\begin{array}{l}\text { Verify that registers ZSC908A and } \\
\text { ZSC908B are unforced. } \\
\text { Verify that the register status is } \\
\text { recorded in the space(s) provided. }\end{array}$ & $V$ & & K/2: \\
\hline 31 & $\begin{array}{l}\text { Press the "RETURN TO CURRENT SCREEN" button to return to the "PORT DO-07-202 MENU" at } \\
\text { 107-OIU-12-105B. }\end{array}$ & $\begin{array}{l}\text { Verify that the "PORT DO-07-202 } \\
\text { MENU" is displayed. }\end{array}$ & $V$ & & Th \\
\hline 32 & $\begin{array}{l}\text { The PCS should automatically de-energize the port close (lower) solenoid valve 07-FEV-9100/C } \\
\text { (Close) } \\
\text { The PCS should then pulse energize solenoid valve 07-FEV-910M/R (Retract) to retract the drum lid } \\
\text { detachment cylinder. }\end{array}$ & $\begin{array}{l}\text { Verify that the drum lid detachment } \\
\text { cylinder is retracted. }\end{array}$ & $V$ & & Kh. \\
\hline
\end{tabular}


HNF-SD-W026-ATR-021 Rev. 1

\begin{tabular}{|c|c|c|c|c|c|}
\hline Sitep & TEST PRQCEDUREV SWEPS & 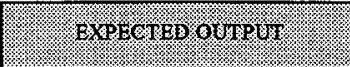 & (1) & f & \\
\hline \multicolumn{6}{|c|}{ 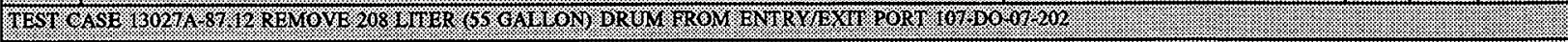 } \\
\hline & 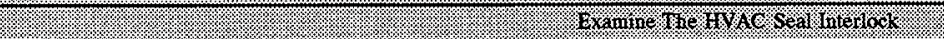 & & & & \\
\hline 33 & $\begin{array}{l}\text { The PCS should automatically de-energize solenoid valve 07-FEV-325A (Deflate) to deflate the HVAC } \\
\text { seal for Drum Entry/Exit Port 107-DO-07-202. The HVAC seal should deflate. }\end{array}$ & Verify that the HVAC seal deflates. & $\gamma$ & & \\
\hline 34 & $\begin{array}{l}\text { The PCS should automatically de-energize solenoid valve 07-FEV-324A (Retract) to retract the drum } \\
\text { centering device for Drum Entry/Exit Port 107-DO-07-202. The drum centering device should retract. } \\
\text { Position switches 07-ZSO-914A and 07-ZSO-914B, because of their forced status, should continue to } \\
\text { indicate that the drum Centering Device is extended. }\end{array}$ & $\begin{array}{l}\text { Verify that the drum centering device } \\
\text { retracts. }\end{array}$ & & & \\
\hline 35 & $\begin{array}{l}\text { The HVAC seal pressure switch 07-PS-916 and the Drum Centering Device position switches 07-ZSO- } \\
\text { 914A and 07-ZSO-914B function as interlocks for the Entry/Exit Port drum exit sequence. The drum } \\
\text { exit sequence should not proceed if the HVAC seal pressure switch is activated, indicating that the } \\
\text { HVAC seal is inflated. Similarly, the drum exit sequence should not proceed if the Drum Centering } \\
\text { Device position switches are not activated, indicating that the Drum Centering Device is extended. } \\
\text { Wait } 2 \text { minutes. }\end{array}$ & $\begin{array}{l}\text { Verify that the "PORT CLOSED } \\
\text { AND LOCKED" status message is } \\
\text { not displayed during the } 2 \text { minute } \\
\text { waiting period. }\end{array}$ & & & \\
\hline 36 & $\begin{array}{l}\text { Review the "PORT DO-07-202 MENU" status. A flashing "SEQUENCE FAILED" message should } \\
\text { be displayed and the "ALARMS" button should be flashing. } \\
\text { Press the "ALARMS" button. The "LOCAL ALARMS" screen should be displayed, with a flashing } \\
\text { "DO-07-202 Failed to Close and Lock" alarm. } \\
\text { Press the "LOCAL ALARMS" screen to display the "LOCAL ALARMS" screen. Buttons should be } \\
\text { displayed near the bottom of the screen to allow alarms to be acknowledged. An active "Port } 202 \\
\text { Centering Device Abnormal Position" alarm should be displayed on this screen. }\end{array}$ & $\begin{array}{l}\text { Verify that a flashing "SEQUENCE } \\
\text { FAILED" message is displayed and } \\
\text { the "ALARMS" button is flashing. } \\
\text { Verify that the "LOCAL ALARMS" } \\
\text { screen is displayed with the active } \\
\text { alarm flashing. } \\
\text { Verify that the "LOCAL ALARMS" } \\
\text { screen with an active "Port } 202 \\
\text { Centering Device Abnormal } \\
\text { Position" alarm is displayed. }\end{array}$ & $V$ & & (⿸丆口 \\
\hline
\end{tabular}


HNF-SD-W026-ATR-021 Rev. 1

\begin{tabular}{|c|c|c|c|c|c|}
\hline Siep & TEST PROQEDURE STEPS & EXPECTED OY Y Y OY & 2. & E.t. & 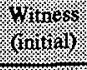 \\
\hline \multicolumn{6}{|c|}{ 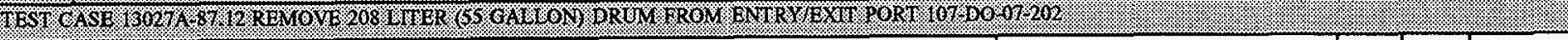 } \\
\hline 37 & $\begin{array}{l}\text { Press the bottom area of the "LOCAL ALARMS" screen to activate the alarm selector feature. The } \\
\text { currently selected alarm should be highlighted. Press the up and down arrow buttons as needed to } \\
\text { select the appropriate alarm. } \\
\text { Press the "ACK" button to acknowledge the selected alarm. } \\
\text { Press the "DONE" button to return to the "LOCAL ALARMS" screen. }\end{array}$ & $\begin{array}{l}\text { Verify that the appropriate alarm is } \\
\text { selected (highlighted). } \\
\text { Verify that the selected alarm is } \\
\text { acknowledged. } \\
\text { Verify that the "LOCAL ALARMS" } \\
\text { screen is displayed and that the } \\
\text { acknowledged "Port } 202 \text { Centering } \\
\text { Device Abnormal Position" alarm is } \\
\text { displayed on this screen. }\end{array}$ & $V$ & & $k n$ \\
\hline 38 & $\begin{array}{l}\text { Unforce the status of the drum centering device position switch (07-ZSO-914A and 07-ZSO-914B) } \\
\text { registers ZSO914A and ZSO914B (Entry/Exit Port 107-DO-07-202) to allow these switches to indicate } \\
\text { that the drum centering device is retracted. Record the unforced register status in the space provided } \\
\text { below. } \\
\text { Unforced ZSO914A Register Status: } \\
\text { Unforced ZSO914B Register Status: }\end{array}$ & $\begin{array}{l}\text { Verify that the register status is } \\
\text { recorded in the space(s) provided. }\end{array}$ & $\checkmark$ & & $K / 2$ \\
\hline 39 & $\begin{array}{l}\text { Press the "RETURN TO CURRENT SCREEN" button to return to the "PORT DO-07-202 MENU" at } \\
\text { 107-OIU-12-105B. }\end{array}$ & $\begin{array}{l}\text { Verify that the "PORT CLOSED } \\
\text { AND LOCKED" message is not } \\
\text { displayed. }\end{array}$ & $\gamma$ & & \\
\hline
\end{tabular}


HNF-SD-W026-ATR-021 Rev. 1

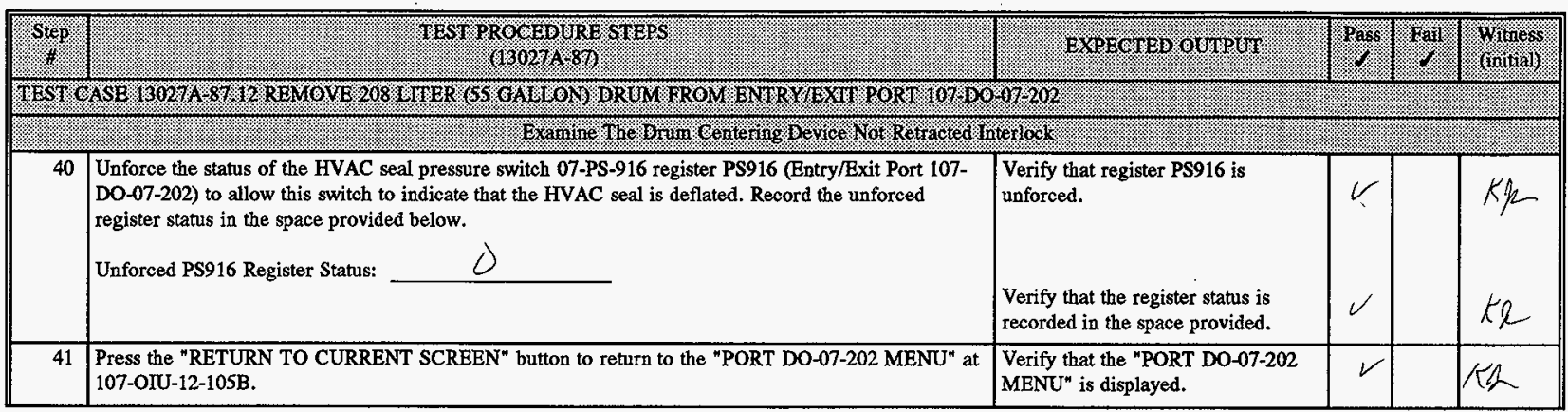


HNF-SD-W026-ATR-021 Rev. 1

\begin{tabular}{|c|c|c|c|c|c|}
\hline Ster. & 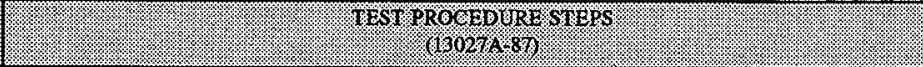 & 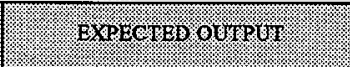 & / & gingitis & (rintial) \\
\hline \multicolumn{6}{|c|}{ 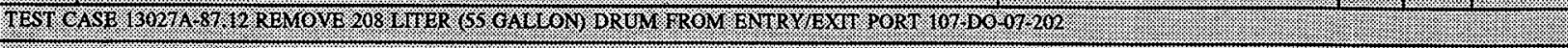 } \\
\hline \multicolumn{6}{|c|}{ (1) ( } \\
\hline 43 & 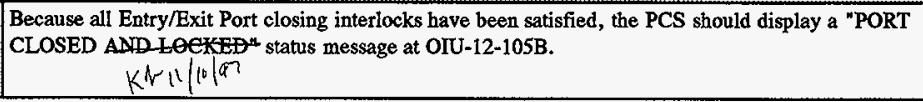 & $\begin{array}{l}\text { Verify that a "PORT CLOSED } \\
\text { toeKDE" status message is } k \text { h } \\
\text { displayed at OIU-12-105B. } 1 !(10 / 97\end{array}$ & $\checkmark$ & & $k 2$ \\
\hline
\end{tabular}


HNN-SD-W026-ATR-021 Rev. 1

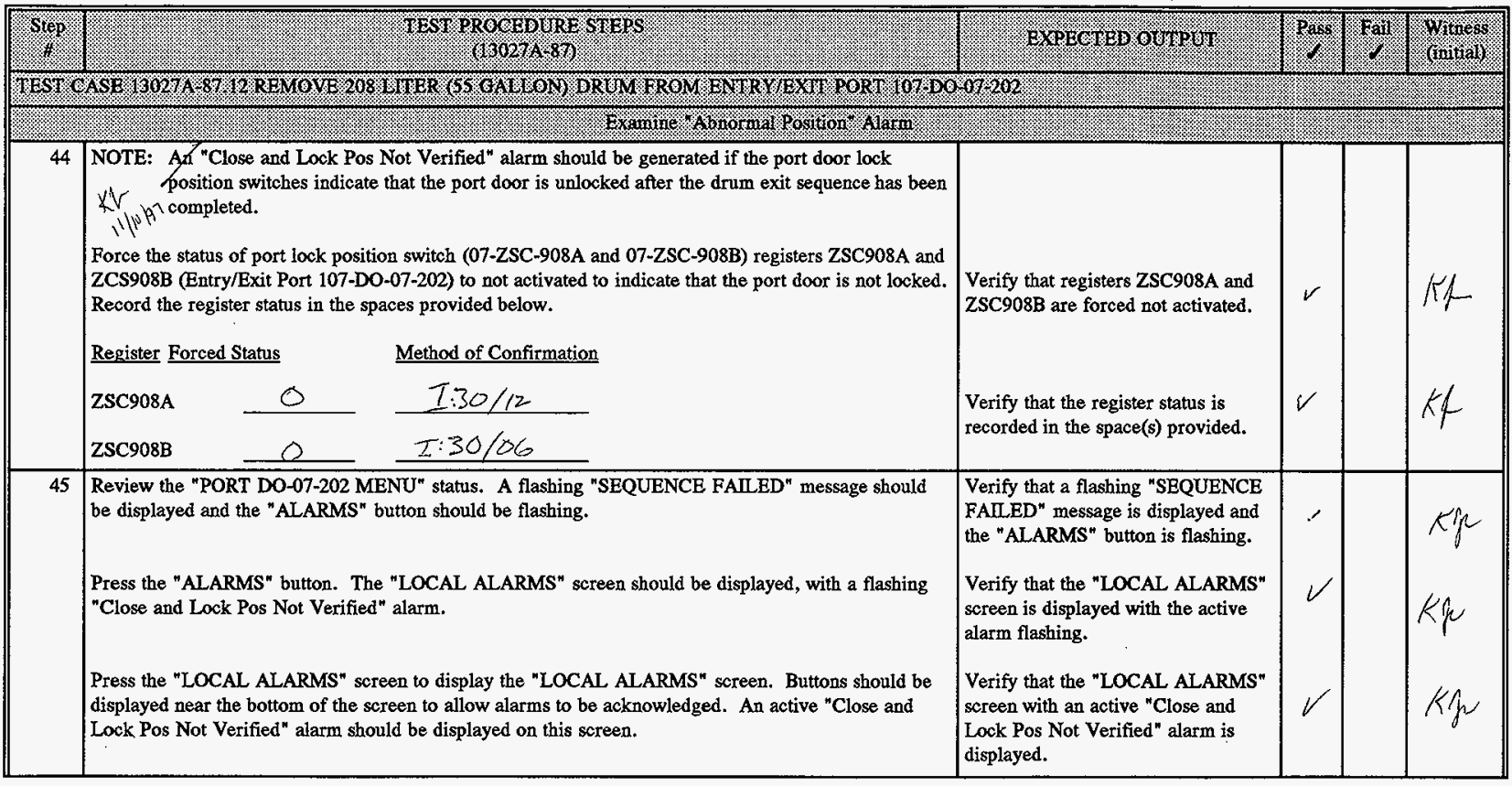


HNF-SD-W026-ATPRO21 Rev. 1

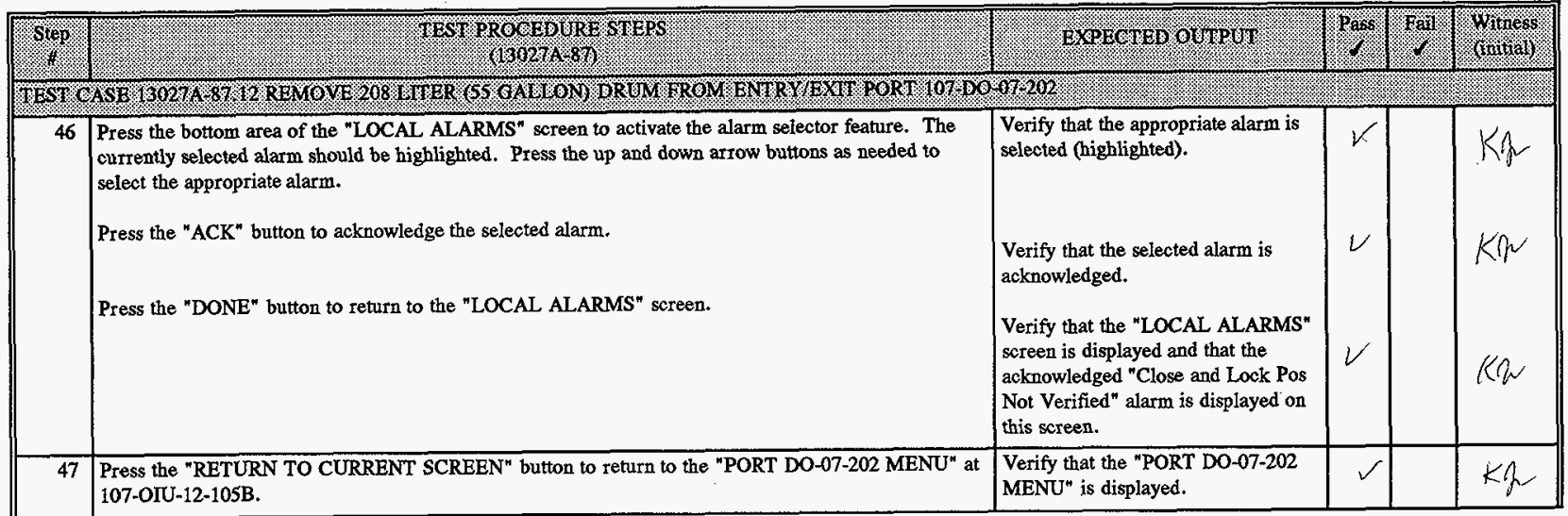


HNF-SD-W026-ATR-021 Rev. 1

\begin{tabular}{|c|c|c|c|c|c|}
\hline sitis & PEST PRGCEDGRT STIEPS & 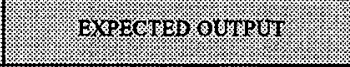 & Pas. & (jarts & (a) \\
\hline \multicolumn{6}{|c|}{ 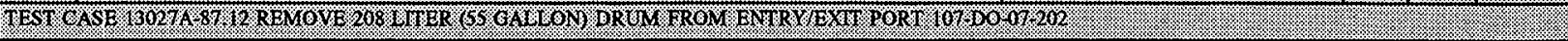 } \\
\hline & 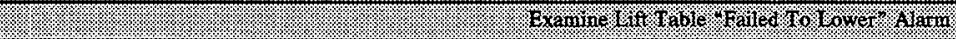 & & & & \\
\hline 48 & $\begin{array}{l}\text { Attempt to move the } 208 \text { liter ( } 55 \text { gallon) Entry/Exit Port lift table (107-LT-09-201E) by activating the } \\
\text { lift table "LOWER" pushbutton at the lift table local control pedestal (107-PC-09-201E). } \\
\text { Because the port is closed but not locked (simulated), the "LOWER" pushbutton at the lift table local } \\
\text { control pedestal should be disabled and have no effect on the lift table. }\end{array}$ & $\begin{array}{l}\text { Verify that activating the "LOWER" } \\
\text { pushbutton has no effect on the lift } \\
\text { table. }\end{array}$ & $\checkmark$ & & 2 \\
\hline 49 & $\begin{array}{l}\text { Force the status of position switch 07-ZS-900A register ZS900A (Entry/Exit Port 107-DO-07-202) to } \\
\text { not activated to indicate that the port door is not lowered closed. Record the forced register status in } \\
\text { the space provided below. } \\
\text { Register Forced Status } \\
\text { ZS900A DFF } \\
\text { The door closed position switch functions as an interiock for the drum to lower. The drum should not } \\
\text { lower until the door closed position switch is activated. }\end{array}$ & $\begin{array}{l}\text { Verify that register ZS900A is forced } \\
\text { not activated. } \\
\text { Verify that the register status is } \\
\text { recorded in the space provided. }\end{array}$ & 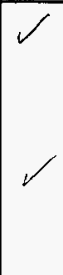 & & $\$ q$ \\
\hline 50 & $\begin{array}{l}\text { Unforce the status of door locked position switch (07-ZS-908A and 07-ZS-908B) registers ZSC908A } \\
\text { and ZSC908B (Entry/Exit Port 107-DO-07-202) to allow these switches to indicate that the port door is } \\
\text { locked. Record the unforced register status in the space provided below. } \\
\text { Unforced ZSC908A Register Status: } \\
\text { Unforced ZSC908B Register Status: }\end{array}$ & $\begin{array}{l}\text { Verify that registers ZSC908A and } \\
\text { ZSC908B are unforced. } \\
\text { Verify that the register status is } \\
\text { recorded in the space(s) provided. }\end{array}$ & $v$ & & $k g$ \\
\hline 51 & $\begin{array}{l}\text { Attempt to move the } 208 \text { liter (55 gallon) Entry/Exit Port lift table (107-LT-09-201E) by activating the } \\
\text { lift table "LOWER" pushbutton at the lift table local control pedestal (107-PC-09-201E). } \\
\text { Because the port is closed but not locked (simulated), the "LOWER" pushbutton at the lift table local } \\
\text { control pedestal should be disabled and have no effect on the lift table. }\end{array}$ & $\begin{array}{l}\text { Verify that activating the "LOWER" } \\
\text { pushbutton has no effect on the lift } \\
\text { table. }\end{array}$ & $\gamma$ & & \\
\hline 52 & $\begin{array}{l}\text { Unforce the status of position switch 07-ZS-900A (Entry/Exit Port 107-DO-07-202) to allow this } \\
\text { switch to indicate that the port door is lowered closed. Record the unforced register status in the space } \\
\text { provided below. } \\
\text { Unforced ZS900A Register Status: }\end{array}$ & $\begin{array}{l}\text { Verify that register ZS900A is } \\
\text { unforced. } \\
\text { Verify that the register status is } \\
\text { recorded in the space provided. }\end{array}$ & $V$ & & \\
\hline
\end{tabular}


HNF-SD-W026-ATR-021 Rev. 1

\begin{tabular}{|c|c|c|c|c|c|}
\hline Stitip: & TEST PROCEDURE SREPST & 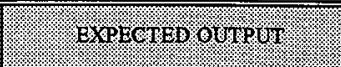 & rass: & (batis & Winiess) \\
\hline \multicolumn{6}{|c|}{ 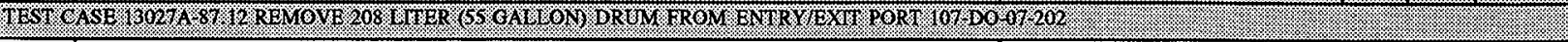 } \\
\hline 53 & $\begin{array}{l}\text { Change LT 201E "Failed to Lower" TD from current value to } 5 \text { sec. Record Register contents. } \\
\text { TD Register: T4:112 Contents: } \quad \mid \mathrm{sew}\end{array}$ & $\begin{array}{l}\text { Verify LT } 201 \mathrm{E} \text { TD is set to } 5 \mathrm{sec} \\
\text { and record Register content. } 4 \mathrm{sec}\end{array}$ & $\checkmark$ & & $K R$ \\
\hline 54 & $\begin{array}{l}\text { Activate the lift table "LOWER" pushbutton at the lift table local control pedestal (107-PC-09-201E) to } \\
\text { lower the Bagless Transfer Port lift table to AGV height. } \\
\text { The "AGV HEIGHT" status indicator 09-ZL-229G at the Lift Table Local Control Pedestal (107-PC- } \\
\text { 09-201E) should be illuminated. }\end{array}$ & $\begin{array}{l}\text { Visually confirm that the lift table is } \\
\text { lowered. } \\
\text { Verify that the "AGV HEIGHT" } \\
\text { status indicator is illuminated. }\end{array}$ & $\checkmark$ & & $\begin{array}{l}\text { Kh } \\
k \Omega\end{array}$ \\
\hline
\end{tabular}


HNF-SD-W026-ATR-021 Rev. 1

\begin{tabular}{|c|c|c|c|c|c|}
\hline Siep & TEST PROCEDURE STEPS & 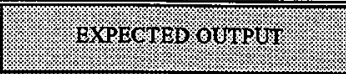 & Pass. & thing & Witiess: \\
\hline \multicolumn{6}{|c|}{ 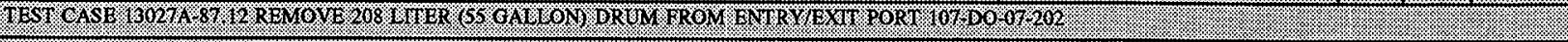 } \\
\hline \multicolumn{6}{|c|}{ 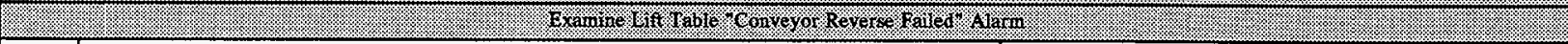 } \\
\hline 55 & $\begin{array}{l}\text { Review the "PORT DO-07-202 MENU" status. A flashing "SEQUENCE FAILED" message should } \\
\text { be displayed and the "ALARMS" button should be flashing. } \\
\text { Press the "ALARMS" button. The "LOCAL ALARMS" screen should be displayed, with a flashing } \\
\text { "Lift Table (201F) Failed to Lower" alarm. } \\
\text { Press the "LOCAL ALARMS" screen to display the "LOCAL ALARMS" screen. Buttons should be } \\
\text { displayed near the bottom of the screen to allow alarms to be acknowledged. An active "Lift Table } \\
\text { (201F) Failed to Lower" alarm should be displayed on this screen. }\end{array}$ & $\begin{array}{l}\text { Verify that a flashing "SEQUENCE } \\
\text { FAILED" message is displayed and } \\
\text { the "ALARMS" button is flashing. } \\
\text { Verify that the "LOCAL ALARMS" } \\
\text { screen is displayed with the active } \\
\text { alarm flashing. } \\
\text { Verify that the "LOCAL ALARMS" } \\
\text { screen with an active "Lith Table } \\
\text { (201F) Failed to Lower" alarm is } \\
\text { displayed. }\end{array}$ & $\checkmark$ & & $k / 2$ \\
\hline 56 & $\begin{array}{l}\text { Press the bottom area of the "LOCAL ALARMS" screen to activate the alarm selector feature. The } \\
\text { currently selected alarm should be highlighted. Press the up and down arrow buttons as needed to } \\
\text { select the appropriate alarm. } \\
\text { Press the "ACK" button to acknowledge the selected alarm. } \\
\text { Press the "DONE" button to return to the "LOCAL ALARMS" screen. }\end{array}$ & $\begin{array}{l}\text { Verify that the appropriate alarm is } \\
\text { selected (highlighted). } \\
\text { Verify that the selected alarm is } \\
\text { acknowledged. } \\
\text { Verify that the "LOCAL ALARMS" } \\
\text { screen is displayed and that the } \\
\text { acknowledged "Lift Table (201F) } \\
\text { Failed to Lower" alarm is displayed } \\
\text { on this screen. }\end{array}$ & $\checkmark$ & & 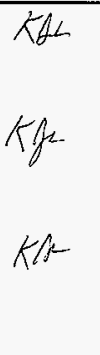 \\
\hline 57 & $\begin{array}{l}\text { Press the "RETURN TO CURRENT SCREEN" button to return to the "PORT DO-07-202 MENU" at } \\
\text { 107-OIU-12-105B. }\end{array}$ & $\begin{array}{l}\text { Verify that the "PORT DO-07-202 } \\
\text { MENU" is displayed. }\end{array}$ & 2 & & 12 \\
\hline 58 & Restore Register T4:112 to value recorded in Step 53. Choged Regrthe be Co sec & $\begin{array}{l}\text { Verify Register } \mathrm{T} 4: 112 \text { is set to } \\
\text { the correct value. }\end{array}$ & $U$ & & $k 2$ \\
\hline
\end{tabular}




\begin{tabular}{|c|c|c|c|c|c|}
\hline Ster. & TEST RROGEPURE STERS & 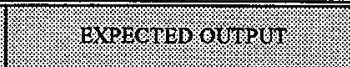 & rasog. & (3) & \\
\hline \multicolumn{6}{|c|}{ 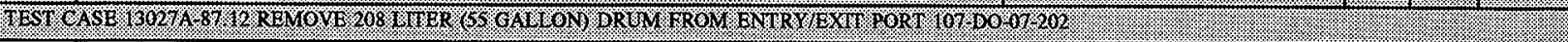 } \\
\hline 59 & $\begin{array}{l}\text { NOTE: This step will be used to simulate a power failure at the lift table. The } 480 \text { volt lift table } \\
\text { local disconnect will be opened during drum transfer under the glovebox port. } \\
\text { Activate the "REVERSE" pushbutton at the Lift Table Local Control Pedestal (107-PC-09-201E) to } \\
\text { energize the lift table conveyor motor in reverse (107-LT-09-201E/M2). After drum has moved } \\
\text { approximately one foot, open the } 480 \text { volt lift table local disconnect to remove power from the lift } \\
\text { table. } \\
\text { The "AGV END" status indicator (09-ZL-229A) at the Lift Table Local Control Pedestal (107-PC-07- } \\
201 E \text { ) should not be illuminated, indicating that the drum is not at the AGV end of the Lift Table. } \\
\text { The roller conveyor should stop. After approximately } 10 \text { seconds, close the } 480 \text { volt lift table local } \\
\text { disconnect to restore power to the lift table. The roller conveyor should not start up again after power } \\
\text { is restored. }\end{array}$ & $\begin{array}{l}\text { Verify that the drum is not } \\
\text { positioned at the AGV end of the } \\
\text { Lift Table. } \\
\text { Verify that the "AGV END" status } \\
\text { indicator is not illuminated, } \\
\text { Verify that the lift table roller } \\
\text { conveyors have stopped and remain } \\
\text { stopped. }\end{array}$ & $\checkmark$ & & $k$ \\
\hline 60 & 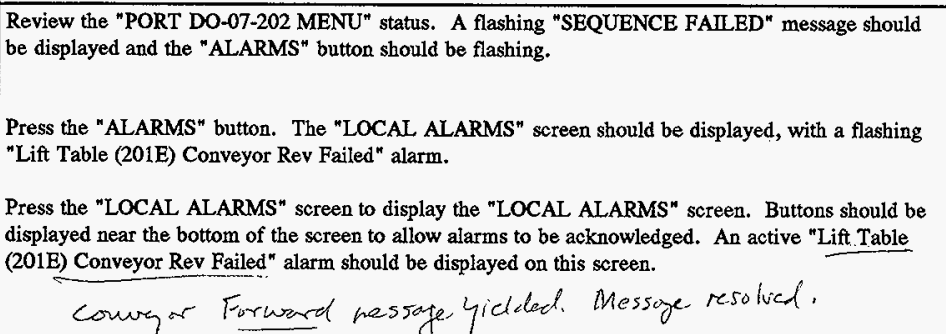 & $\begin{array}{l}\text { Verify that a flashing "SEQUENCE } \\
\text { FAllED" message is displayed and } \\
\text { the "ALARMS" button is flashing. } \\
\text { Verify that the "LOCAL ALARMS" } \\
\text { screen is displayed with the active } \\
\text { alarm flashing. } \\
\text { Verify that the "LOCAL ALARMS" } \\
\text { screen with an active "Lift Table } \\
\text { (201D) Conveyor Rev Failed" alarm } \\
\text { is displayed. }\end{array}$ & $\checkmark$ & & or \\
\hline
\end{tabular}


HNF-SD-W026-ATR-021 Rev. 1

\begin{tabular}{|c|c|c|c|c|c|}
\hline Stept:- & 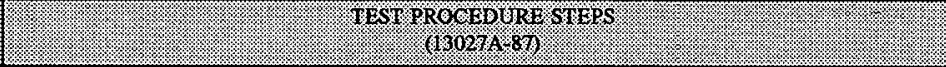 & 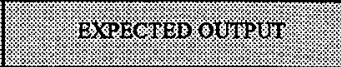 & Pens & 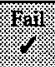 & (Wintings: \\
\hline \multicolumn{6}{|c|}{ 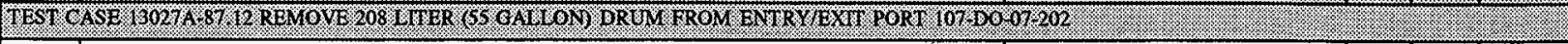 } \\
\hline 61 & $\begin{array}{l}\text { Press the bottom area of the "LOCAL ALARMS" screen to activate the alarm selector feature. The } \\
\text { currently selected alarm should be highlighted. Press the up and down arrow buttons as needed to } \\
\text { select the appropriate alarm. } \\
\text { Press the "ACK" button to acknowledge the selected alarm. } \\
\text { Press the "DONE" button to return to the "LOCAL ALARMS" screen. }\end{array}$ & $\begin{array}{l}\text { Verify that the appropriate alarm is } \\
\text { selected (hightighted). } \\
\text { Verify that the selected alarm is } \\
\text { acknowledged. } \\
\text { Verify that the "LOCAL, ALARMS" } \\
\text { screen is displayed and that the } \\
\text { acknowledged "Lift Table (201E) } \\
\text { Conveyor Rev Failed" alarm is } \\
\text { displayed on this screen. }\end{array}$ & $\checkmark$ & & $k \gamma$ \\
\hline 62 & $\begin{array}{l}\text { Press the "RETURN TO CURRENT SCREEN" button to return to the "PORT DO-07-202 MENU" at } \\
\text { 107-OIU-12-105B. }\end{array}$ & $\begin{array}{l}\text { Verify that the "PORT DO-07-202 } \\
\text { MENU" is displayed and the screen } \\
\text { status displays "Sequence failed". }\end{array}$ & $V$ & & $k n$ \\
\hline 63 & $\begin{array}{l}\text { Activate the "REVERSE" pushbutton at the Lift Table Local Control Pedestal (107-PC-09-201E) to } \\
\text { energize the lift table conveyor motor in reverse (107-LT-09-201E/M2) until the drum is at the AGV } \\
\text { end of the Lift Table. } \\
\text { The "AGV END" status indicator (09-ZL-231A) at the Lift Table Local Control Pedestal (107-PC-07- } \\
\text { 201E) should be illuminated, indicating that the drum is at the AGV end of the Lift Table. }\end{array}$ & $\begin{array}{l}\text { Verify that the drum is at the AGV } \\
\text { end of the Lift Table. } \\
\text { Verify that the "AGV END" status } \\
\text { indicator is illuminated. }\end{array}$ & $\checkmark$ & & $k \mathfrak{R}$ \\
\hline
\end{tabular}


HNF-SD-W026-ATR-021 Rev. 1

\begin{tabular}{|c|c|c|c|c|c|}
\hline Step: & TEST PROCEDURE STEPS. & 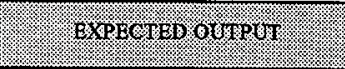 & (1) & f. & (initinges \\
\hline \multicolumn{6}{|c|}{ 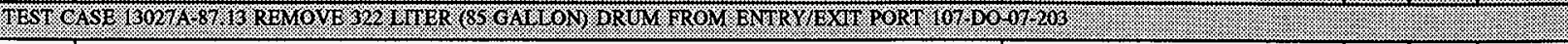 } \\
\hline 1 & $\begin{array}{ll}\text { WARNING: } & \text { The "MATE DRUM TO } 322 \text { LITER ( } 85 \text { GALLON) ENTRY/EXIT PORT 107-DO- } \\
& 07-203^{2} \text { test case is a prerequisite for this test case. Do not perform this test case } \\
\text { unless the pre-requisite test cases have already been successfully completed. }\end{array}$ & $\begin{array}{l}\text { Verify that the "MATE DRUM TO } \\
322 \text { LITER ( } 85 \text { GALLON) } \\
\text { ENTRY/EXIT PORT 107-DO-07- } \\
203 \text { " test case has already been } \\
\text { successfully completed prior to } \\
\text { running this test case. }\end{array}$ & & & \\
\hline 2 & $\begin{array}{l}\text { The following sequence of test procedure steps involve automatic port door closing, } \\
\text { controlled by LCU } 102 \text { (Referred to as the "PCS" in this test procedure). These test } \\
\text { procedure steps should be carefully reviewed to permit rapid verification of test } \\
\text { conditions during the automatic port opening sequence. }\end{array}$ & $\begin{array}{l}\text { Verify that the remaining test } \\
\text { procedure steps in this test case are } \\
\text { carefully reviewed prior to } \\
\text { completing this test case. }\end{array}$ & & & \\
\hline 3 & $\begin{array}{l}\text { Confirm that the "LLW RWM GLOVEBOX MAIN MENU" screen is displayed at OIU-12-105B. If a } \\
\text { sub-menu is displayed, press the "MAIN MENU" button to return to the Main Menu. }\end{array}$ & $\begin{array}{l}\text { Verify that the "LLW RWM } \\
\text { GLOVEBOX MAIN MBNU" screen } \\
\text { is displayed at OIU-12-105B. }\end{array}$ & $\mathscr{S}$ & & Kh \\
\hline 4 & $\begin{array}{l}\text { Confirm that the Entry/Exit Port (107-DO-07-203) door is rotated open and that a drum is mated to the } \\
\text { port. }\end{array}$ & $\begin{array}{l}\text { Visually verify that the Entry/Exit } \\
\text { Port (107-DO-07-203) door is rotated } \\
\text { open and that a drum is mated to the } \\
\text { port. }\end{array}$ & 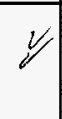 & & \\
\hline 5 & $\begin{array}{l}\text { Confirm that no items are present that would prevent the Entry/Exit Port (107-D0-07-203) from } \\
\text { properly closing. }\end{array}$ & $\begin{array}{l}\text { Visually verify that no items are } \\
\text { present that would prevent the } \\
\text { Entry/Exit Port (107-DO-07-203) } \\
\text { from properly closing. }\end{array}$ & $\sqrt{ }$ & & \\
\hline 6 & $\begin{array}{l}\text { Force the status of position switch 07-ZSC-911 register ZSC911 (Entry/Exit Port 107-DO-07-203) to } \\
\text { not activated to indicate that the port door is not rotated closed. Record the register status in the space } \\
\text { provided below. } \\
\text { Register Forced Status } \\
\text { ZSC911 } \\
\text { The door rotated closed position switch functions as an interlock for the Entry/Exit Port. The drum } \\
\text { exit sequence should not proceed until the position switch is activated. }\end{array}$ & $\begin{array}{l}\text { Verify that register ZSC } 911 \text { is forced } \\
\text { not activated. } \\
\text { Verify that the register status is } \\
\text { recorded in the space provided. }\end{array}$ & & & \\
\hline
\end{tabular}


HNF-SD-W026-ATR-021 Rev. 1

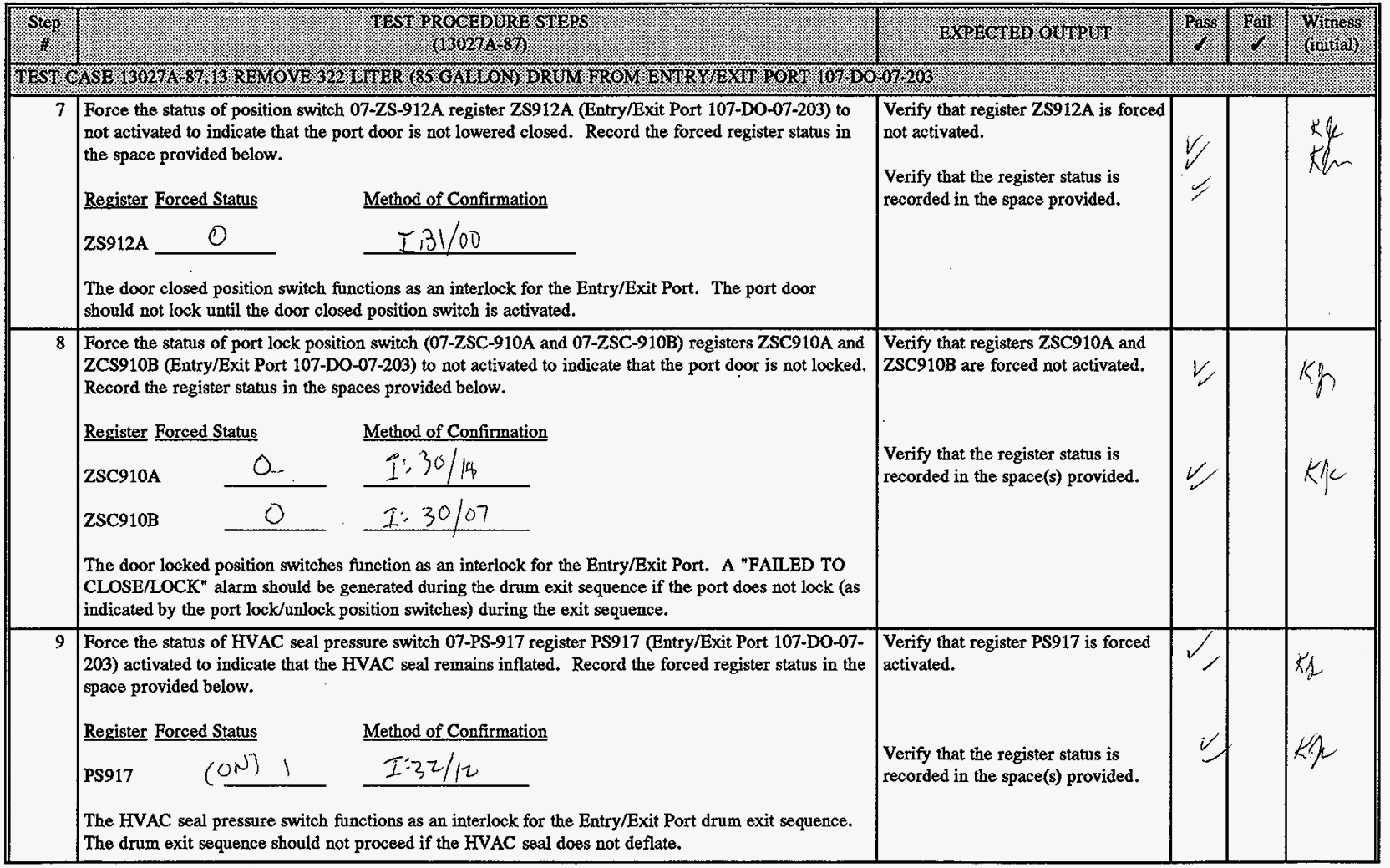


HNF-SD-W026-ATR-021 Rev. 1

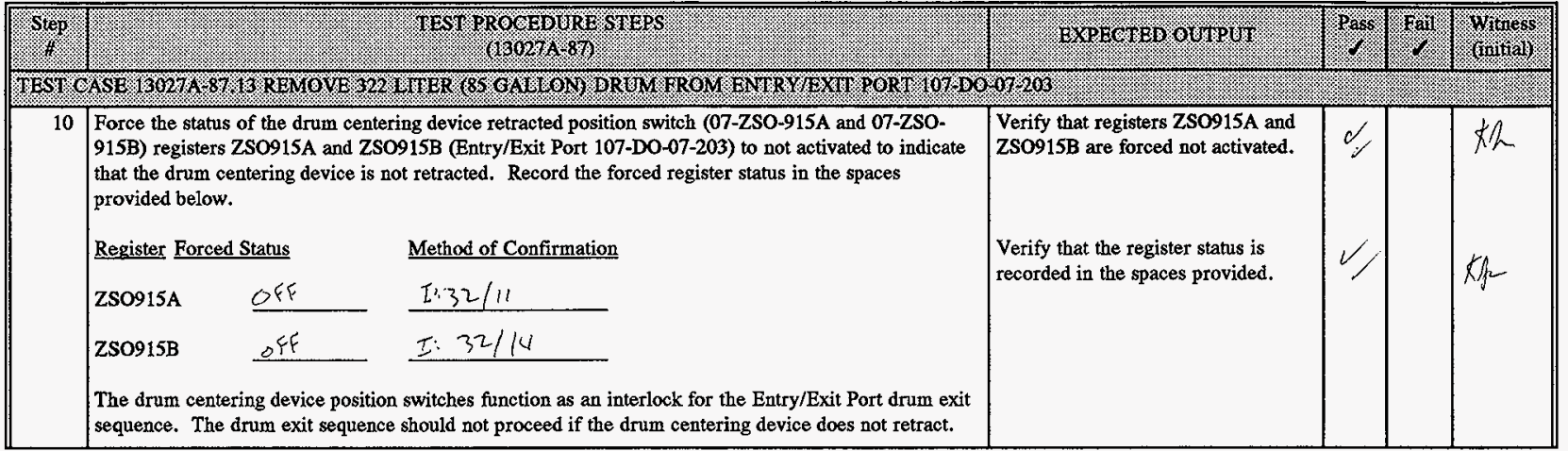


HNF-SD-W026-ATR 021 Rev. 1

\begin{tabular}{|c|c|c|c|c|c|}
\hline Stop & TEST PRG CEDURR S VIEPS & EXPERTEOOUKSU & pars. & rail & Winines) \\
\hline \multicolumn{6}{|c|}{ 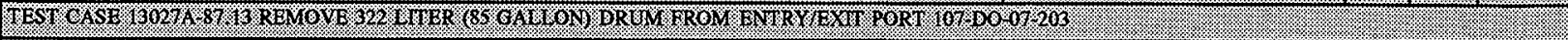 } \\
\hline \multicolumn{6}{|c|}{ 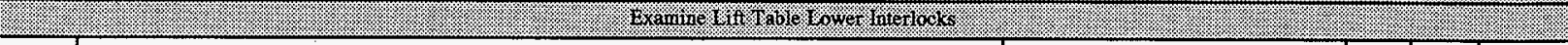 } \\
\hline 11 & $\begin{array}{l}\text { Attempt to move the } 322 \text { liter (85 gallon) Entry/Exit Port lift table (107-LT-09-201D) by activating the } \\
\text { lift table "LOWER" pushbutton at the lift table local control pedestal (107-PC-09-201D). } \\
\text { The Entry/Exit Port should be open with a drum mated to this port. Because the port is not closed and } \\
\text { locked, the "LOWER" pushbutton at the lift table local control pedestal should be disabled and have no } \\
\text { effect on the lift table. }\end{array}$ & $\begin{array}{l}\text { Verify that activating the "LOWER" } \\
\text { pushbutton has no effect on the lift } \\
\text { table. }\end{array}$ & U/ & & \\
\hline 12 & $\begin{array}{l}\text { Attempt to move the Entry/Exit Port lift table (107-LT-09-201D) roller conveyors by activating the lift } \\
\text { table "FORWARD" and "REVERSE" pushbuttons at the lift table local control pedestal (107-PC-09- } \\
\text { 201D). } \\
\text { Because the lift table is not lowered, activating the "FORWARD" and "REVERSE" pushbuttons at the } \\
\text { lift table local control pedestal (107-PC-09-201D) should be disabled and have no effect on the lift } \\
\text { table. }\end{array}$ & $\begin{array}{l}\text { Verify that activating the } \\
\text { "FORWARD" and "REVERSE" } \\
\text { pushbuttons has no effect on the lift } \\
\text { table. }\end{array}$ & & & $k M$ \\
\hline
\end{tabular}


HNP-SD-W026-ATR_021 Rev. 1

\begin{tabular}{|c|c|c|c|c|c|}
\hline Siep: & TEST PROGEDURE STIES : & PXPESTED OWTPU: & Pass: & rait. & (initian) \\
\hline \multicolumn{6}{|c|}{ 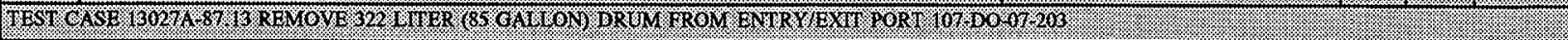 } \\
\hline \multicolumn{6}{|c|}{ U. } \\
\hline 13 & $\begin{array}{l}\text { NOTE: The manipulator serves as an interlock for Entry/Exit Port operation. When the manipulator } \\
\text { is not at the park position, the Entry/Exit Port should not be able to close. The manipulator } \\
\text { is initially slightly displaced from the park position to allow this interlock to be tested. } \\
\text { Place the LLW RWM Waste Manipulator (107-EM-07-201) approximately one foot from park position } \\
1 \text { (Closest to Bagless Transfer Port (107-DO-07-201) with both manipulator arms fully parked. }\end{array}$ & $\begin{array}{l}\text { Visually verify that the waste } \\
\text { manipulator is approximately one } \\
\text { foot away park position } 1 \text { with both } \\
\text { arms parked. }\end{array}$ & & & $k\left(\mu^{2}\right.$ \\
\hline 14 & $\begin{array}{l}\text { Press the "CLOSE PORT" button from the "PORT DO-07-203 MENU" screen at OIU-12-105B. } \\
\text { Because the manipulator is not parked, the port (107-DO-07-203) should not close. }\end{array}$ & $\begin{array}{l}\text { Verify that the port door does not } \\
\text { rotate closed. } \\
\text { Verify that a "PORT CLOSING..." } \\
\text { message is not displayed at OIU-12- } \\
\text { 105B. }\end{array}$ & & & $k \eta$ \\
\hline 15 & $\begin{array}{l}\text { Place the LIW RWM Waste Manipulator (107-EM-07-201) at park position } 1 \text { (Closest to Bagless } \\
\text { Transfer Port (107-DO-07-201) with both manipulator arms fully parked. }\end{array}$ & $\begin{array}{l}\text { Visually verify that the waste } \\
\text { manipulator is at park position } 1 \text { with } \\
\text { both arms parked. }\end{array}$ & & & $\Varangle g$ \\
\hline
\end{tabular}


HNF-SD-W026-ATRO21 Rev. 1

\begin{tabular}{|c|c|c|c|c|c|}
\hline Step & TIST PROOEDURE STEPS. & 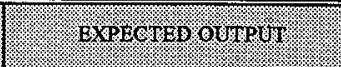 & Pas. & T.1. & (ritial) \\
\hline \multicolumn{6}{|c|}{ 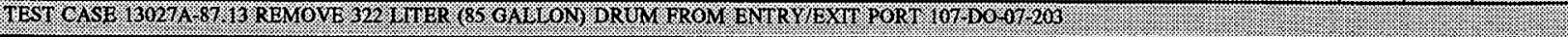 } \\
\hline \multicolumn{6}{|c|}{ 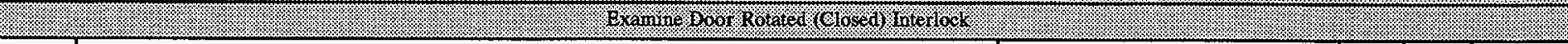 } \\
\hline 16 & $\begin{array}{l}\text { Press the "PORT DO-07-203 MENU" button from the "LLW RWM GLOVEBOX MAIN MENU" } \\
\text { screen at OIU-12-105B. }\end{array}$ & $\begin{array}{l}\text { Verify that the "PORT DO-07-203 } \\
\text { MENU" screen is displayed. }\end{array}$ & $y$ & & $k \eta$ \\
\hline 17 & Press the "CLOSE PORT" button from the PORT DO-07-203 Menu at OIU-12-105B. & $\begin{array}{l}\text { Verify that a "PORT CLOSING..." } \\
\text { message is displayed at OIU-12- } \\
105 B .\end{array}$ & & & $k k$ \\
\hline 18 & $\begin{array}{l}\text { The PCS should puise activate solenoid valve 07-FEV-910H/C (Close) to pressurize the door rotation } \\
\text { cylinder to move the port door to the rotated closed position. } \\
\text { The "Door Closed" position switch (07-ZSC-911) register ZSC911 should be remain forced not } \\
\text { activated when the door is fully rotated. }\end{array}$ & $\begin{array}{l}\text { Verify that the port door rotates } \\
\text { closed. } \\
\text { Verify that the port door rotated } \\
\text { closed position switch } 07-Z S C-911 \\
\text { register ZSC911 remains forced not } \\
\text { activated. }\end{array}$ & 4 & & $\begin{array}{l}k / 2 \\
k h\end{array}$ \\
\hline 19 & $\begin{array}{l}\text { The door rotated closed position switch functions as an interlock for the Entry/Exit Port. The drum } \\
\text { exit sequence should not proceed to lower the port door closed until the "Door Closed" position switeh } \\
\text { is activated. } \\
\text { Wait } 2 \text { minutes. }\end{array}$ & $\begin{array}{l}\text { Verify that the port door does not } \\
\text { lower closed during the } 2 \text { minute } \\
\text { waiting period. }\end{array}$ & & & Ka \\
\hline 20 & $\begin{array}{l}\text { Unforce register ZSC911 (Entry/Exit Port 107-DO-07-203) to allow position switch 07-ZSC-911 to } \\
\text { indicate that the port door is rotated closed. Record the unforced register status in the space provided } \\
\text { below. } \\
\text { Unforced ZSC911 Register Status: }\end{array}$ & $\begin{array}{l}\text { Verify that register ZSC911 is } \\
\text { unforced. } \\
\text { Verify that the register status is } \\
\text { recorded in the space provided. }\end{array}$ & & & KR \\
\hline
\end{tabular}


HNF-SD-W026-ATR-021 Rev. 1

\begin{tabular}{|c|c|c|c|c|c|}
\hline Stror & TEST PROCEDYRD SYEPS & 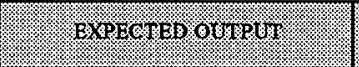 & Pas. & 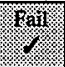 & (Winitians \\
\hline \multicolumn{6}{|c|}{ 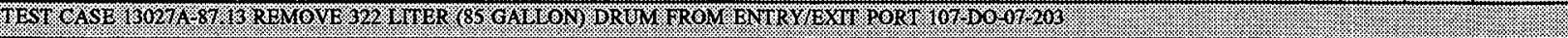 } \\
\hline & 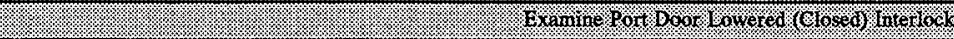 & . & & & \\
\hline 21 & $\begin{array}{l}\text { Because the port door is rotated closed, position switch } 07-Z \text { SC-911 should be activated, indicating that } \\
\text { the door is rotated closed and the sequence should continue. } \\
\text { After position switch 07-ZSC-911 indicates that the port door is rotated closed, the PCS should pulse } \\
\text { energize solenoid valve 07-FEV-910N/C (Close) to lower the port door closed. }\end{array}$ & $\begin{array}{l}\text { Verify that the port (107-DO-07-203) } \\
\text { door lowers closed. }\end{array}$ & $\checkmark$ & & 1 \\
\hline 22 & $\begin{array}{l}\text { The PCS should automatically de-energize vacuum gereration solenoid valve 07-FEV-910D/V and } \\
\text { vacuum isolation solenoid valve 07-FEV-910F to remove vacuum from the drum lid. } \\
\text { The PCS should then energize solenoid valve 07-FEV-910L/E (Extend) to extend the drum lid } \\
\text { detachment cylinder. }\end{array}$ & $\begin{array}{l}\text { Verify that the drum lid detachment } \\
\text { cylinder is extended for port } 107- \\
\text { DO-07-203. } \\
\text { Verify that the-drum-lid-does not- } \\
\text { adhere to the portdoer. }\end{array}$ & $\alpha$ & & \\
\hline 23 & $\begin{array}{l}\text { The PCS should automatically energize the lift table motor 107-LT-09-201D/M1 to lower the lift table } \\
\text { to "Drum Centering" height. } \\
\qquad 351 / 8-353 / 16\end{array}$ & $\begin{array}{l}\text { Verify that the lift table lowers to } \\
\text { "Drum Centering" height. } \\
\text { Verify that the port door lowers to } \\
\text { the "closed" position. }\end{array}$ & & & t \\
\hline 24 & $\begin{array}{l}\text { The door lowered closed position switch functions as an interlock for the Entry/Exit Port. The port } \\
\text { door should not lock until the door lowered closed position switch 07-ZS-912A is activated. } \\
\text { Wait } 2 \text { minutes. }\end{array}$ & $\begin{array}{l}\text { Verify that the port door locking } \\
\text { cylinders do not extend during the } \\
\text { two (2) minute waiting period. }\end{array}$ & $V_{t \rightarrow d}$ & vaing & $k^{2}$ \\
\hline 25 & $\begin{array}{l}\text { Unforce the status of position switch } 07-Z S-912 \mathrm{~A} \text { (Entry/Exit Port 107-DO-07-203) to allow this } \\
\text { switch to indicate that the port door is lowered closed. Record the unforced register status in the space } \\
\text { provided below. } \\
\text { Unforced ZS912A Register Status: }\end{array}$ & $\begin{array}{l}\text { Verify that register ZS912A is } \\
\text { unforced. } \\
\text { Verify that the register status is } \\
\text { recorded in the space(s) provided. }\end{array}$ & & & $1-1$ \\
\hline
\end{tabular}




\begin{tabular}{|c|c|c|c|c|c|}
\hline sing & 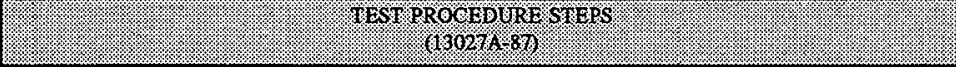 & RXPECIEDOOYMYUT & Paks & Fin: & (initive) \\
\hline \multicolumn{6}{|c|}{ 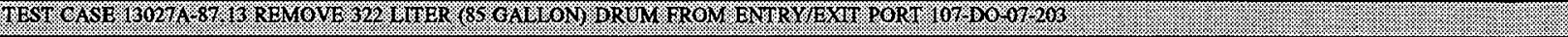 } \\
\hline & 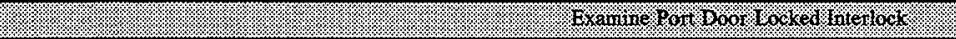 & & & & \\
\hline 26 & $\begin{array}{l}\text { When position switch 07-ZS-912A status is unforced, this switch should correctly indicate the position } \\
\text { of the port door. } \\
\text { Because the PCS has lowered the lift table to "Drum Centering" height, the port door should be } \\
\text { completely lowered and position switch 07-ZS-912A should be activated, indicating that the port door } \\
\text { is lowered closed. } \\
\text { After position switch 07-ZS-912A is activated, the PCS should energize solenoid valve 07-FEV-910E/L } \\
\text { (Lock) to extend the port door locking cylinders. }\end{array}$ & $\begin{array}{l}\text { Verify that the port door locking } \\
\text { cylinders fully extend to lock the } \\
\text { port door. }\end{array}$ & & & \\
\hline 27 & $\begin{array}{l}\text { The door locked position switches 07-ZSC-910A and 07-ZSC-910B function as an interlock for the } \\
\text { Entry/Exit Port. The drum exit sequence should stop if the door locked position switches are not } \\
\text { activated. } \\
\text { Wait } 2 \text { minutes. }\end{array}$ & $\begin{array}{l}\text { Verify that the drum lid detachment } \\
\text { cylinder does not retract during the } \\
\text { two (2) minute waiting period. }\end{array}$ & & & \\
\hline 28 & $\begin{array}{l}\text { Review the "PORT DO-07-203 MENU" status. A flashing "SEQUENCE FAILED" message should } \\
\text { be displayed and the "ALARMS" button should be flashing. } \\
\text { Press the "ALARMS" button. The "LOCAL ALARMS" screen should be displayed, with a flashing } \\
\text { "DO-07-203 Failed to Close and Lock" alarm. } \\
\text { Press the "LOCAL ALARMS" screen to display the "LOCAL ALARMS" screen. Buttons should be } \\
\text { displayed near the bottom of the screen to allow alarms to be acknowledged. An active "DO-07-203 } \\
\text { Failed to Close and Lock" alarm should be displayed on this screen. }\end{array}$ & $\begin{array}{l}\text { Verify that a flashing "SEQUENCE } \\
\text { FAILED" message is displayed and } \\
\text { the "ALARMS" button is flashing. } \\
\text { Verify that the "LOCAL ALARMS" } \\
\text { screen is displayed with the active } \\
\text { alarm flashing. } \\
\text { Verify that the "LOCAL ALARMS" } \\
\text { screen with an active "DO-07-203 } \\
\text { Failed to Close and Lock" alarm is } \\
\text { displayed. }\end{array}$ & & & $x \neq$ \\
\hline
\end{tabular}


HNF-SD-W026-ATR-021 Rev. 1

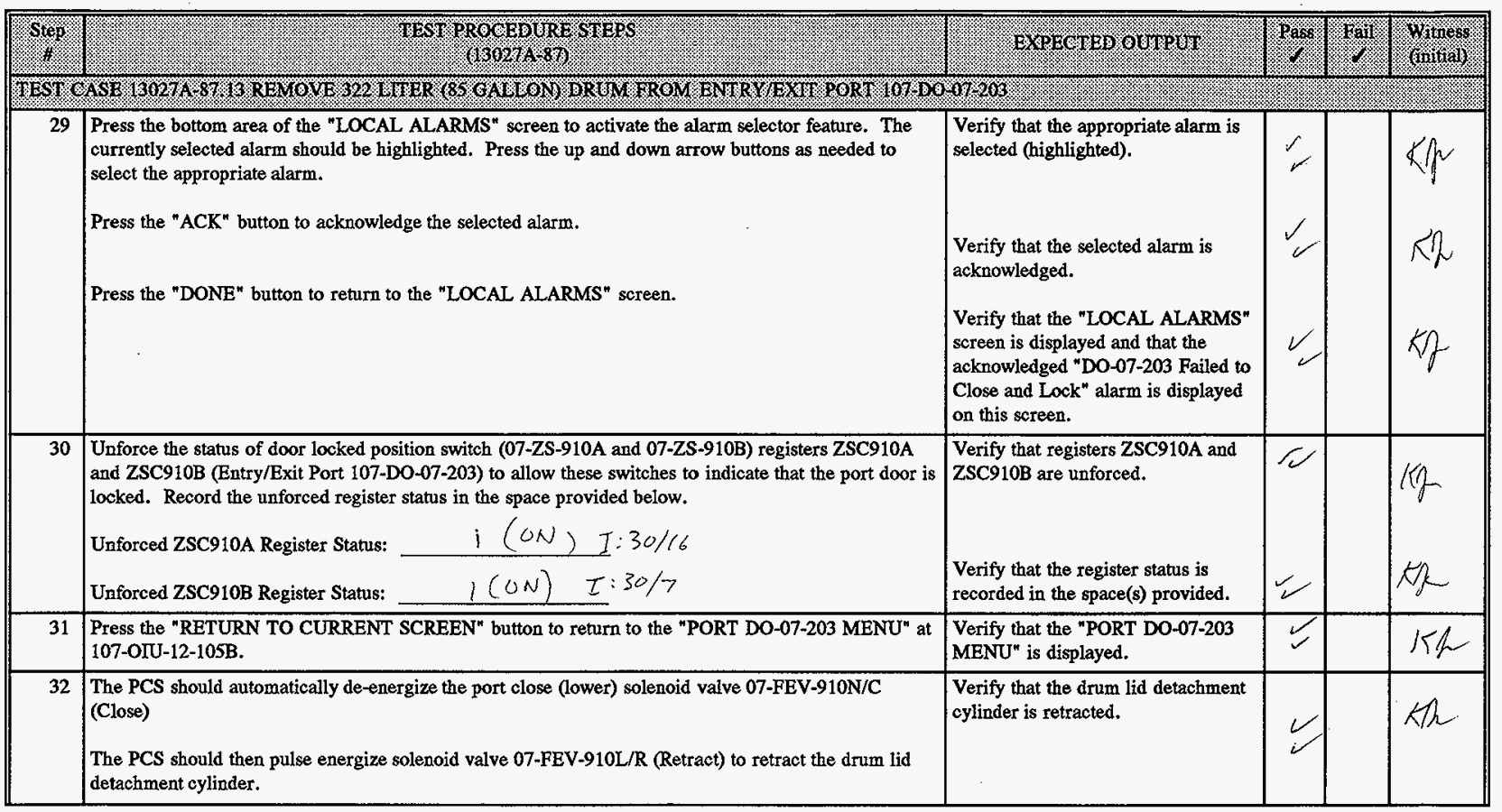


HNF-SD-W026-ATR-021 Rev. 1

\begin{tabular}{|c|c|c|c|c|c|}
\hline Siop. & 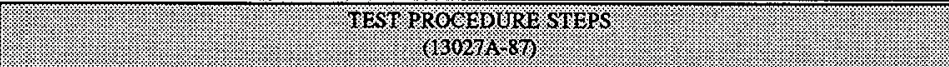 & 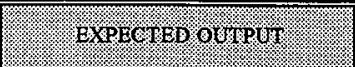 & STass. & ratio & Winessos \\
\hline \multicolumn{6}{|c|}{ 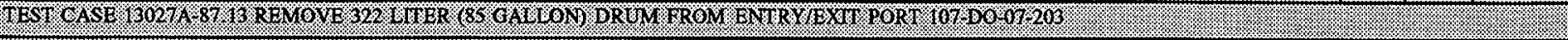 } \\
\hline 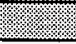 & 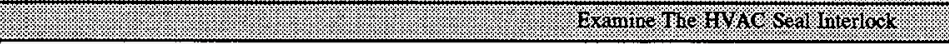 & & & & \\
\hline 33 & $\begin{array}{l}\text { The PCS should automatically de-energize solenoid valve 07-FEV-3285A (Deflate) to deflate the } \\
\text { HVAC seal for Drum Entry/Exit Port 107-DO-07-203. The HVAC seal should deflate. }\end{array}$ & Verify that the HVAC seal deflates. & 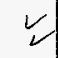 & & $k / h$ \\
\hline 34 & $\begin{array}{l}\text { The PCS should automatically de-energize solenoid valve 07-FEV-324B (Retract) to retract the drum } \\
\text { centering device for Drum Entry/Exit Port 107-DO-07-203. The drum centering device should retract. } \\
\text { Position switches 07-ZSO-915A and 07-ZSO-915B, because of their forced status, should continue to } \\
\text { indicate that the drum Centering Device is extended. }\end{array}$ & $\begin{array}{l}\text { Verify that the drum centering device } \\
\text { retracts. }\end{array}$ & $a$ & & Q \\
\hline 35 & $\begin{array}{l}\text { The HVAC seal pressure switch 07-PS-917 and the Drum Centering Device position switches 07-ZSO- } \\
\text { 915A and 07-ZSO-915B function as interlocks for the Entry/Exit Port drum exit sequence. The drum } \\
\text { exit sequence should not proceed if the HVAC seal pressure switch is activated, indicating that the } \\
\text { HVAC seal is inflated. Similarly, the drum exit sequence should not proceed if the Drum Centering } \\
\text { Device position switches are not activated, indicating that the Drum Centering Device is extended. } \\
\text { Wait } 2 \text { minutes. }\end{array}$ & $\begin{array}{l}\text { Verify that a "PORT CLOSED AND } \\
\text { LOCKED" status message is not } \\
\text { displayed at OIU-12-105B during the } \\
2 \text { minute waiting period. }\end{array}$ & $\checkmark$ & & h \\
\hline 36 & $\begin{array}{l}\text { Review the "PORT DO-07-203 MENU" status. A flashing "SEQUENCE FAILED" message should } \\
\text { be displayed and the "ALARMS" button should be flashing. } \\
\text { Press the "ALARMS" button. The "LOCAL ALARMS" screen should be displayed, with a flashing } \\
\text { "DO-07-203 Failed to Close and Lock" alarm. } \\
\text { Press the "LOCAL ALARMS" screen to display the "LOCAL ALARMS" screen. Buttons should be } \\
\text { displayed near the bottom of the screen to allow alarms to be acknowledged. An active "Port } 203 \\
\text { Centering Device Abnormal Position" alarm should be displayed on this screen. }\end{array}$ & $\begin{array}{l}\text { Verify that a flashing "SEQUENCE } \\
\text { FAILD" message is displayed and } \\
\text { the "ALARMS" button is flashing. } \\
\text { Verify that the "LOCAL ALARMS" } \\
\text { screen is displayed with the active } \\
\text { alarm flashing. } \\
\text { Verify that the "LOCAL ALARMS" } \\
\text { screen with an active "Port } 203 \\
\text { Centering Device Abnormal } \\
\text { Position" alarm is displayed. }\end{array}$ & 2 & & $k p$ \\
\hline
\end{tabular}


HNF-SD-W026-ATR-021 Rev. 1

\begin{tabular}{|c|c|c|c|c|c|}
\hline Step & 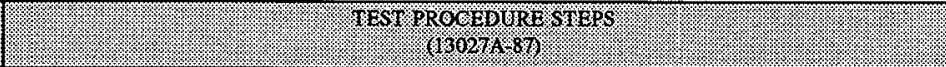 & W & ris & Faris & (winina) \\
\hline \multicolumn{6}{|c|}{ 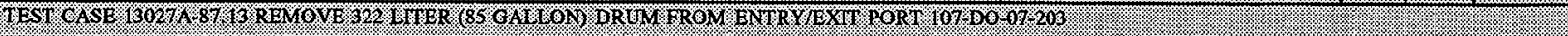 } \\
\hline 37 & $\begin{array}{l}\text { Press the bottom area of the "LOCAL ALARMS" screen to activate the alarm selector feature. The } \\
\text { currently selected alarm should be highlighted. Press the up and down arrow buttons as needed to } \\
\text { select the appropriate alarm. } \\
\text { Press the "ACK" button to acknowledge the selected alarm. } \\
\text { Press the "DONE" button to return to the "LOCAL ALARMS" screen. }\end{array}$ & $\begin{array}{l}\text { Verify that the appropriate alarm is } \\
\text { selected (highlighted). } \\
\text { Verify that the selected alarm is } \\
\text { acknowledged. } \\
\text { Verify that the "LOCAL ALARMS" } \\
\text { screen is displayed and that the } \\
\text { acknowledged "PORT CLOSED } \\
\text { AND LOCKED" status message is } \\
\text { not displayed on this screen. }\end{array}$ & $\checkmark$ & & Kh \\
\hline 38 & $\begin{array}{l}\text { Unforce the status of the drum centering device position switch (07-ZSO-915A and 07-ZSO-915B) } \\
\text { registers ZSO915A and ZSO915B (Entry/Exit Port 107-DO-07-203) to allow these switches to indicate } \\
\text { that the drum centering device is retracted. Record the unforced register status in the space provided } \\
\text { below. } \\
\text { Unforced ZSO915A Register Status: } \\
\text { Unforced ZSO915B Register Status: }\end{array}$ & $\begin{array}{l}\text { Verify that the register status is } \\
\text { recorded in the space(s) provided. }\end{array}$ & $V$ & & KMg \\
\hline 39 & $\begin{array}{l}\text { Press the "RETURN TO CURRENT SCREEN" button to return to the "PORT DO-07-203 MENU" at } \\
\text { 107-OIU-12-105B. }\end{array}$ & $\begin{array}{l}\text { Verify that the "PORT CLOSED } \\
\text { AND LOCKED" message is not } \\
\text { displayed. }\end{array}$ & $\nu$ & & \\
\hline
\end{tabular}


HNF-SD-W026-ATR-021 Rev, I

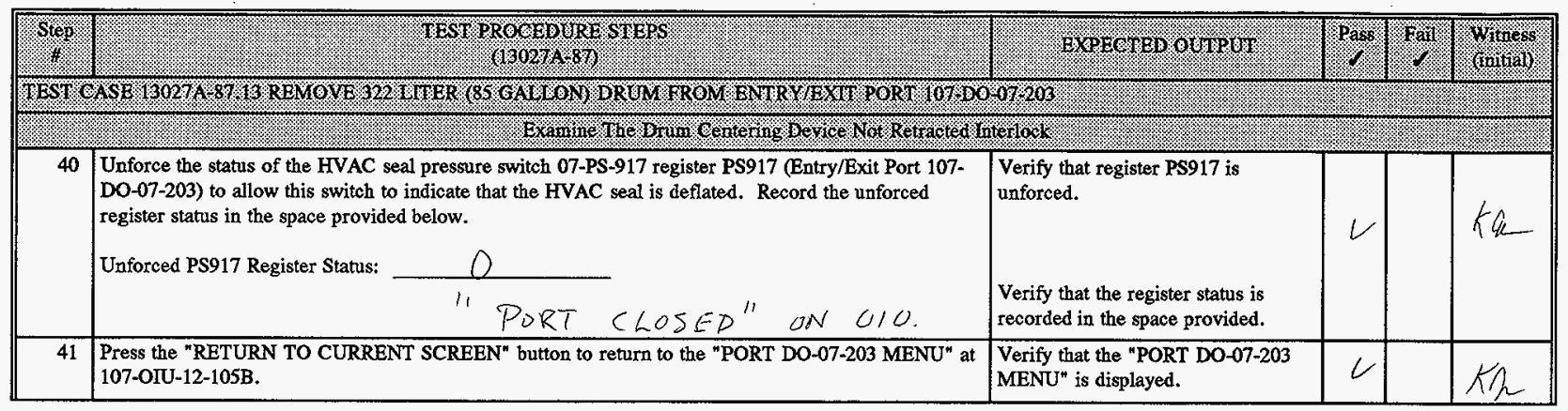


Lb) 01) 11

\begin{tabular}{|c|c|c|c|c|c|}
\hline vy & & A & 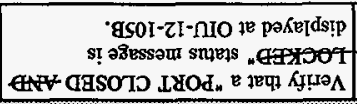 & 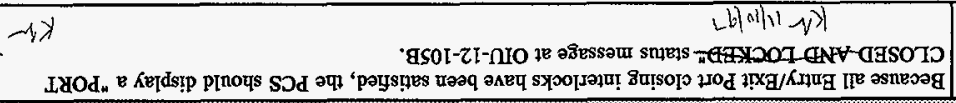 & Zt \\
\hline & & & (2) & 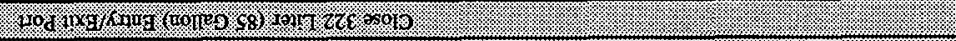 & \\
\hline & 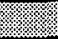 & & 800 & 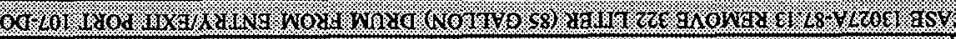 & 6.58 \\
\hline sisaning & $\frac{1}{4}$ & Sysig & 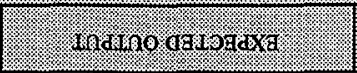 & 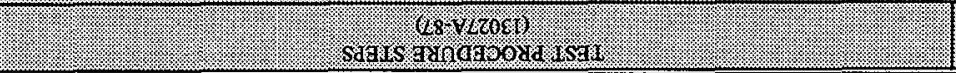 & 6sis \\
\hline
\end{tabular}

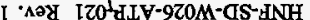


HNF-SD-W026-ATR-021 Rev. 1

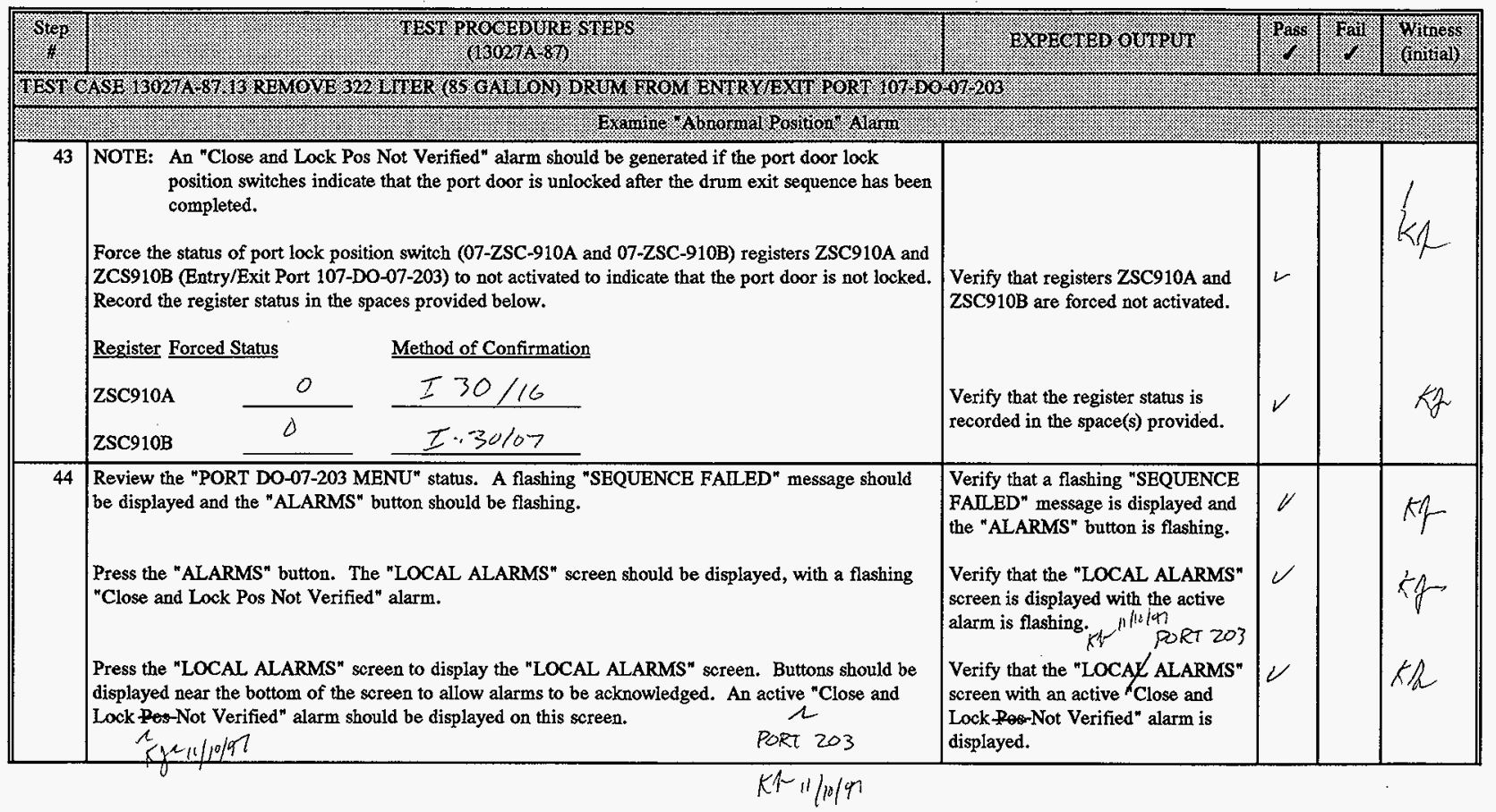


HINF-SD-W026-ATP+021 Rev. 1

\begin{tabular}{|c|c|c|c|c|c|}
\hline Sigen & 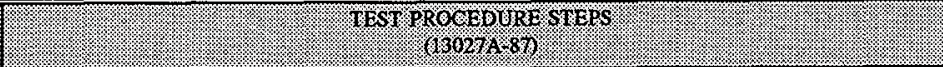 & 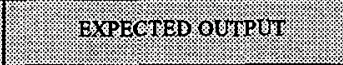 & Paso & firit. & (inining) \\
\hline \multicolumn{6}{|c|}{ 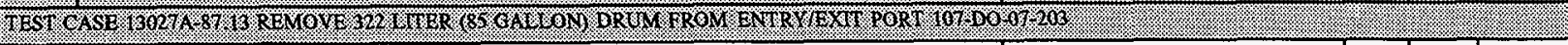 } \\
\hline 45 & $\begin{array}{l}\text { Press the bottom area of the "LOCAL ALARMS" screen to activate the alarm selector feature. The } \\
\text { currently selected alarm should be highlighted. Press the up and down arrow buttons as needed to } \\
\text { select the appropriate alarm. } \\
\text { Press the "ACK" button to acknowledge the selected alarm. } \\
\text { Press the "DONE" button to return to the "LOCAL ALARMS" screen. }\end{array}$ & $\begin{array}{l}\text { Verify that the appropriate alarm is } \\
\text { selected (highlighted). } \\
\text { Verify that the selected alarm is } \\
\text { acknowledged. } \\
\text { Verify that the "LOCAL ALARMS" } \\
\text { screen is displayed and that the } \\
\text { acknowledged Close and Lock Pos } \\
\text { Not Verified" alarm is displayed on } \\
\text { this screen. }\end{array}$ & $r$ & & \\
\hline 46 & $\begin{array}{l}\text { Press the "RETURN TO CURRENT SCREEN" button to return to the "PORT DO-07-203 MENU" at } \\
\text { 107-ONU-12-105B. }\end{array}$ & $\begin{array}{l}\text { Verify that the "PORT DO-07-203 } \\
\text { MENU" is displayed. }\end{array}$ & $V$ & & $\pi g$ \\
\hline
\end{tabular}


HNF-SD-W026-ATR-021 Rev. 1

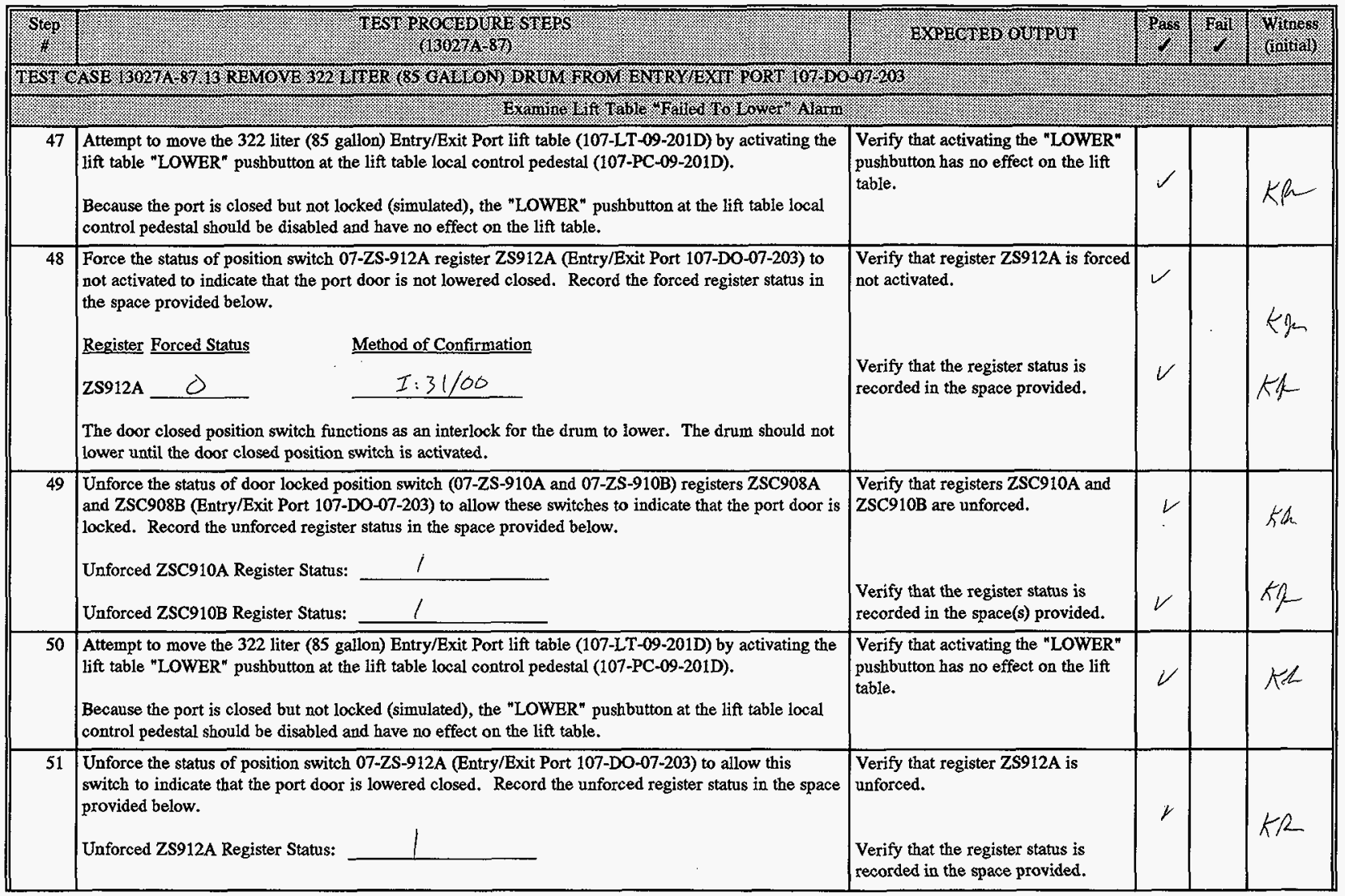


HNP-SD-W026-ATR-021 Rev. 1

\begin{tabular}{|c|c|c|c|c|c|}
\hline sien & TEST PROCEDURAR STERS : & EXPEOTEY OUMPUI & Ifas: & 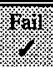 & (initivil) \\
\hline \multicolumn{6}{|c|}{ 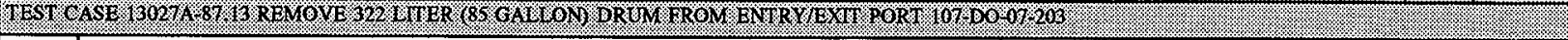 } \\
\hline 52 & $\begin{array}{l}\text { Change LT 201D "Failed to Lower" TD from current value to } \not \rho \text { sec. Record Register Contents. } \\
\text { TD Register: } \text { T4:116 Contents: } \quad 120\end{array}$ & $\begin{array}{l}\text { Verify LT } 2010 \text { TD value is set to } \$ \\
\text { sec. and record register contents. } 1 \\
K / 1 / 6 / 6\end{array}$ & & & $K M$ \\
\hline 53 & $\begin{array}{l}\text { Activate the lift table "LOWER" pushbutton at the lift table local control pedestal (107-PC-09-201D) to } \\
\text { lower the Bagless Transfer Port lift table to its lowered position below AGV height. } \\
\text { The "DOWN OVERTRAVEL" status indicator 09-ZL-227C at the Lift Table Local Control Pedestal } \\
\text { (107-PC-09-201D) should not be illuminated when the lift table is lowered. }\end{array}$ & $\begin{array}{l}\text { Visually confirm that the lift table is } \\
\text { lowered. } \\
\text { Verify that the "DOWN } \\
\text { OVERTRAVEL" status indicator 07- } \\
\text { ZL-227C is not illuminated. }\end{array}$ & $\checkmark$ & & $k \Omega$ \\
\hline
\end{tabular}


HNF-SD-W026-ATR-021 Rev. 1

\begin{tabular}{|c|c|c|c|c|c|}
\hline step & 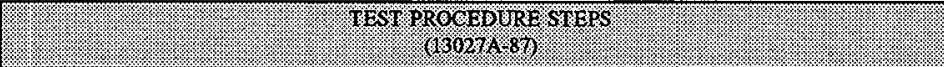 & 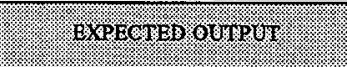 & 1asos. & 1. & 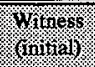 \\
\hline \multicolumn{6}{|c|}{ 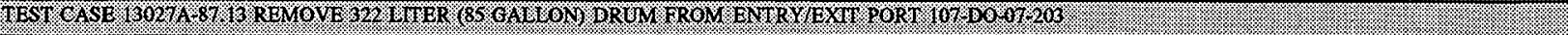 } \\
\hline \multicolumn{6}{|c|}{ 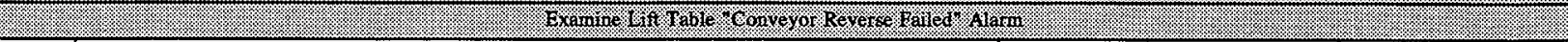 } \\
\hline 54 & $\begin{array}{l}\text { Review the "PORT DO-07-203 MENU" status. A flashing "SEQUENCE FAIIED" message should } \\
\text { be displayed and the "ALARMS" button should be flashing. } \\
\text { Press the "ALARMS" button. The "LOCAL ALARMS" screen should be displayed, with a flashing } \\
\text { "Lift Table (201D) Failed to Lower" alarm. } \\
\text { Press the "LOCAL ALARMS" screen to display the "LOCAL ALARMS" screen. Buttons should be } \\
\text { displayed near the bottom of the screen to allow alarms to be acknowledged. An active "Lift Table } \\
\text { (201D) Failed to Lower" alarm should be displayed on this screen. }\end{array}$ & $\begin{array}{l}\text { Verify that a flashing "SEQUENCE } \\
\text { FAILED" message is displayed and } \\
\text { the "ALARMS" button is flashing. } \\
\text { Verify that the "LOCAL ALARMS" } \\
\text { screen is displayed with the active } \\
\text { alarm flashing. } \\
\text { Verify that the "LOCAL ALARMS" } \\
\text { screen with an active "Lift Table } \\
\text { (201D) Failed to Lower" alarm is } \\
\text { displayed. }\end{array}$ & $\checkmark$ & & 2 \\
\hline 55 & $\begin{array}{l}\text { Press the bottom area of the "LOCAL ALARMS" screen to activate the alarm selector feature. The } \\
\text { currently selected alarm should be highlighted. Press the up and down arrow buttons as needed to } \\
\text { select the appropriate alarm. } \\
\text { Press the "ACK" button to acknowledge the selected alarm. } \\
\text { Press the "DONE" button to return to the "LOCAL ALARMS" screen. }\end{array}$ & $\begin{array}{l}\text { Verify that the appropriate alarm is } \\
\text { selected (highlighted). } \\
\text { Verify that the selected alarm is } \\
\text { acknowledged. } \\
\text { Verify that the "LOCAL ALARMS" } \\
\text { screen is displayed and that the } \\
\text { acknowledged "Lift Table (201F) } \\
\text { Failed to Lower" alarm is displayed } \\
\text { on this screen. }\end{array}$ & $\checkmark$ & & \\
\hline 56 & $\begin{array}{l}\text { Press the "RETURN TO CURRENT SCREEN" button to return to the "PORT DO-07-203 MENU" at } \\
107-010-12-105 \mathrm{~B} \text {. }\end{array}$ & $\begin{array}{l}\text { Verify that the "PORT DO-07-203 } \\
\text { MENU" is displayed. }\end{array}$ & $\nu$ & & KA \\
\hline 57 & Restore Register $\mathrm{T} 4: 116$ to value recorded in Step 52 Thestront to 60 sec. & $\begin{array}{l}\text { Verify Register T4:116 is set to } \\
\text { the correct value. }\end{array}$ & $v$ & & Kqu \\
\hline
\end{tabular}




\begin{tabular}{|c|c|c|c|c|c|}
\hline Step: & TEST PROCEDUIR STEPS & EXPETSEG OUTPY & Pass: & 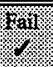 & Wintress \\
\hline \multicolumn{6}{|c|}{ 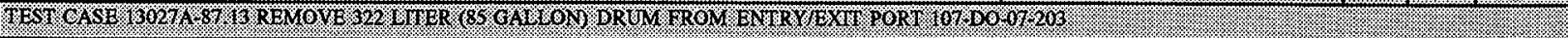 } \\
\hline 58 & $\begin{array}{l}\text { NOTE: This step will be used to simulate a power failure at the lift table. The } 480 \text { volt lift table } \\
\text { local disconnect will be opened during drum transfer under the glovebox port. } \\
\text { Activate the "REVERSE" pushbutton at the Lift Table Local Control Pedestal (107-PC-09-201D) to } \\
\text { energize the lift table conveyor motor in reverse (107-LT-09-201D/M2). After drum has moved } \\
\text { approximately one foot, open the } 480 \text { volt lift table local disconnect to remove power from the lift } \\
\text { table. } \\
\text { The "AGV END" status indicator (09-ZL-227A) at the Lift Table Local Control Pedestal (107-PC-07- } \\
\text { 201D) should not be illuminated, indicating that the drum is not at the AGV end of the Lift Table. } \\
\text { The roller conveyor should stop. After approximately } 10 \text { seconds, close the } 480 \text { volt lift table local } \\
\text { disconnect to restore power to the lift table. The roller conveyor should not start up again after power } \\
\text { is restored. }\end{array}$ & $\begin{array}{l}\text { Verify that the drum is not } \\
\text { positioned at the AGV end of the } \\
\text { Lift Table. } \\
\text { Verify that the "AGV END" status } \\
\text { indicator is not illuminated, } \\
\text { Verify that the lift table roller } \\
\text { conveyors have stopped and remain } \\
\text { stopped. }\end{array}$ & $\checkmark$ & & $\begin{array}{l}\text { kh } \\
k \mu \\
k n\end{array}$ \\
\hline 59 & $\begin{array}{l}\text { Review the "PORT DO-07-201 MENU" status. A flashing "SEQUENCE FAIIED" message should } \\
\text { be displayed and the "ALARMS" button should be flashing. } \\
\text { Press the "ALARMS" button. The "LOCAL ALARMS" screen should be displayed, with a flashing } \\
\text { "Lift Table (201D) Conveyor Revailed" alarm. } \\
\text { REVERE Kr-11/10 Mn } \\
\text { Press the "LOCAL ALARMS" screen to display the "LOCAL ALARMS" screen. Buttons should be } \\
\text { displayed near the bottom of the sereen to allow alarms to be acknowledged. An active "Lift Table } \\
\text { (201D) Conveyor Rev Failed" alarm should be displayed on this screen. }\end{array}$ & $\begin{array}{l}\text { Verify that a flashing "SEQUENCE } \\
\text { FAILED" message is displayed and } \\
\text { the "ALARMS" button is flashing. } \\
\text { Verify that the "LOCAL ALARMS" } \\
\text { screen is displayed with the active } \\
\text { alarm flashing. } \\
\text { Verify that the "LOCAL ALARMS" } \\
\text { screen with an active "Lift Table } \\
\text { (201D) Conveyor Pour Failed" alarm } \\
\text { is displayed. Reverse. }\end{array}$ & $\checkmark$ & & $k$ \\
\hline
\end{tabular}


HNF-SD-W026-ATR-021 Rev. 1

\begin{tabular}{|c|c|c|c|c|c|}
\hline step: & (1) & 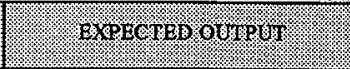 & 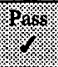 & ralis & (ivitivilus \\
\hline \multicolumn{6}{|c|}{ 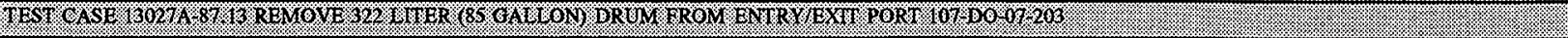 } \\
\hline 60 & $\begin{array}{l}\text { Press the bottom area of the "LOCAL ALARMS" screen to activate the alarm selector feature. The } \\
\text { currently selected alarm should be highlighted. Press the up and down arrow buttons as needed to } \\
\text { select the appropriate alarm. } \\
\text { Press the "ACK" button to acknowledge the selected alarm. } \\
\text { Press the "DONE" button to return to the "LOCAL ALARMS" screen. }\end{array}$ & $\begin{array}{l}\text { Verify that the appropriate alarm is } \\
\text { selected (highlighted). } \\
\text { Verify that the selected alarm is } \\
\text { acknowledged. } \\
\text { Verify that the "LOCAL ALARMS" } \\
\text { screen is displayed and that the } \\
\text { acknowledged "Lift Table (201F) } \\
\text { Conveyor Rev Failed" alarm is } \\
\text { displayed on this screen. }\end{array}$ & $\checkmark$ & & Ko \\
\hline 61 & $\begin{array}{l}\text { Press the "RETURN TO CURRENT SCREEN" button to return to the "PORT DO-07-201 MENU" at } \\
\text { 107-OIU-12-105B. }\end{array}$ & $\begin{array}{l}\text { Verify that the "PORT DO-07-201 } \\
\text { MENU" is displayed and the screen } \\
\text { status displays "Sequence failed". }\end{array}$ & $\checkmark$ & & Ka \\
\hline 62 & $\begin{array}{l}\text { Activate the "REVERSE" pushbutton at the Lift Table Local Control Pedestal (107-PC-09-201F) to } \\
\text { energize the lift table conveyor motor in reverse (107-LT-09-201F/M2) until the drum is at the AGV } \\
\text { end of the Lift Table. } \\
\text { The "AGV END" status indicator (09-ZL-231A) at the Lift Table Local Control Pedestal (107-PC-07- } \\
\text { 201F) should be illuminated, indicating that the drum is at the AGV end of the Lift Table. }\end{array}$ & $\begin{array}{l}\text { Verify that the drum is at the AGV } \\
\text { end of the Lift Table. } \\
\text { Verify that the "AGV END" status } \\
\text { indicator (09-ZL-231A) is } \\
\text { illuminated. }\end{array}$ & $V$ & & Kh \\
\hline 63 & $\begin{array}{l}\text { Activate the lift table "RAISE" pushbutton at the lift table local control pedestal (107-PC-09-201F) to } \\
\text { raise the lift table to AGV Height. } \\
\text { The "AGV HEIGHT" status indicator at the Lift Table Local Control Pedestal (107-PC-07-201F) } \\
\text { should be illuminated, indicating that the drum is at the AGV Height. }\end{array}$ & $\begin{array}{l}\text { Visually Verify that the Lift Table } \\
\text { (107-LT-09-201F) is at AGV height. } \\
\text { Verify that the "AGV HEIGHT" } \\
\text { status indicator is illuminated. }\end{array}$ & 2 & & $k \bumpeq$ \\
\hline & (3) & & & & \\
\hline
\end{tabular}




\begin{tabular}{|c|c|c|c|c|c|}
\hline Sten & 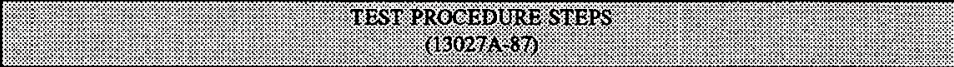 & BXPECIEDSOUTPUIT & Pars & (I) & (rining) \\
\hline \multicolumn{6}{|c|}{ 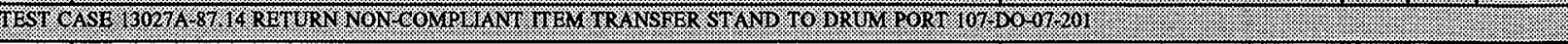 } \\
\hline 1 & 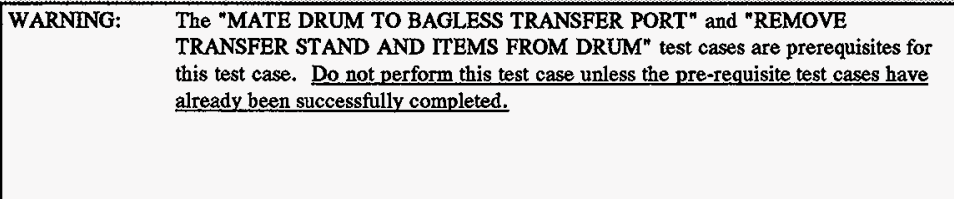 & $\begin{array}{l}\text { Verify that the "MATE DRUM TO } \\
\text { BAGLESS TRANSFER PORT" and } \\
\text { "REMOVE TRANSFER STAND } \\
\text { AND ITEMS FROM DRUM" test } \\
\text { cases have already been successfully } \\
\text { completed prior to running this test } \\
\text { case. }\end{array}$ & $\checkmark$ & & \\
\hline 2 & A Drath \& Schrader drum should be mated to the Bagless Transfer Port (107-DO-07-201). & $\begin{array}{l}\text { Verify that a Drath \& Schrader drum } \\
\text { is mated to the Bagless Transfer Port } \\
\text { (107-D0-07-201). }\end{array}$ & 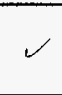 & & Klo \\
\hline 3 & $\begin{array}{l}\text { The Bagless Transfer Port door should be rotated completely open to allow the non-compliant item } \\
\text { transfer stand to be placed in the Drath \& Schrader drum. }\end{array}$ & $\begin{array}{l}\text { Verify that the Bagless Transfer Port } \\
\text { is open. }\end{array}$ & $\checkmark$ & & Kh. \\
\hline 4 & $\begin{array}{l}\text { The manipulator should be located at park position number } 2 \text { near the } 208 \text { liter ( } 85 \text { gallon) Entry/Exit } \\
\text { Port (107-DO-07-203). The manipulator arms should be parked. } \\
\text { If the manipulator is not in this position, use the manipulator controls to move the manipulator to park } \\
\text { position number } 2 \text { and park the manipulator arms. }\end{array}$ & $\begin{array}{l}\text { Visually verify that the waste } \\
\text { manipulator is at park position } \\
\text { number } 2 \text { with both arms parked. }\end{array}$ & & & \\
\hline 5 & $\begin{array}{l}\text { During test case 13027A-87.04 "REMOVE TRANSFER STAND AND ITEMS FROM DRUM", the } \\
\text { non-compliant item transfer stand should have been attached to the glovebox monorail hoist and } \\
\text { positioned near the } 322 \text { liter ( } 85 \text { gallon) entry exit port (107-D0-07-203). }\end{array}$ & $\begin{array}{l}\text { Verify that the non-compliant item } \\
\text { transfer stand is attached to the } \\
\text { glovebox hoist. } \\
\text { Verify that the non-compliant item } \\
\text { transfer stand is positioned near the } \\
322 \text { liter ( } 85 \text { gallon) entry exit port. }\end{array}$ & 1 & & \\
\hline 6 & $\begin{array}{l}\text { NOTE: The hoist pendant 107-PC-07-009A "PENDANT SELECT" switch should have been turned to } \\
\text { the "PEND A" position during test procedure setup. This action should disable hoist pendant } \\
\text { 107-PC-07-009B. } \\
\text { Examine hoist pendant 107-PC-07-009B }\end{array}$ & $\begin{array}{l}\text { Verify that the "ENABLED" } \\
\text { indicator for hoist pendant 107-PC- } \\
\text { 07-009B is NOT illuminated. }\end{array}$ & 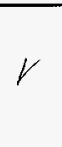 & & \\
\hline 7 & $\begin{array}{l}\text { Activate the hoist pendant 107-PC-07-009B "LOWER" pushbutton to attempt to lower the hoist hook. } \\
\text { Because hoist pendant 107-PC-07-009B is not enabled, the hoist hook should not lower. }\end{array}$ & $\begin{array}{l}\text { Verify that the hoist hook does not } \\
\text { move when the hoist pendant 107- } \\
\text { PC-07-009B "LOWER" pushbutton } \\
\text { is activated. }\end{array}$ & $\checkmark$ & & \\
\hline
\end{tabular}


HNF-SD-W026-ATR-021 Rev. 1

\begin{tabular}{|c|c|c|c|c|c|}
\hline Step & 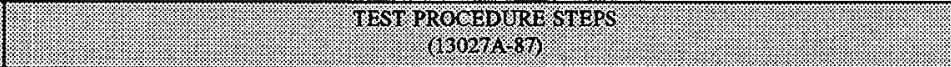 & 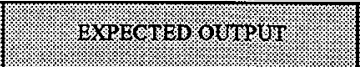 & Tas: & 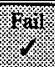 & Vinitinat) \\
\hline \multicolumn{6}{|c|}{ 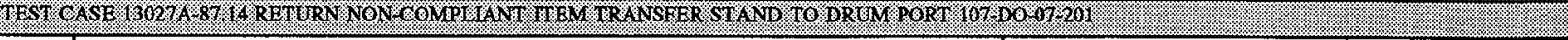 } \\
\hline 8 & $\begin{array}{l}\text { Activate the Trolley/Hoist Pendant 107-PC-07-009A "RAISE" pushbutton as needed to raise the hoist } \\
\text { with the non-compliant item transfer stand until the transfer stand is positioned at least one foot above } \\
\text { alt items in the transfer stand travel path. }\end{array}$ & $\begin{array}{l}\text { Verify that there is at least one foot } \\
\text { (approximately) of travel clearance } \\
\text { beneath the non-compliant item } \\
\text { transfer stand along the entire length } \\
\text { of the glovebox. }\end{array}$ & & & \\
\hline 9 & $\begin{array}{l}\text { Activate the Trolley/Hoist Pendant (107-PC-07-009A) "Left" and "Right" pushbuttons as needed to } \\
\text { energize trolley motor 107-CR-07-201/M1 (Trolley Traverse Drive) forward so that the trolley } \\
\text { SLOWLY travels the entire length of its travel path, and is positioned over the } 208 \text { liter ( } 55 \text { gallon) } \\
\text { Bagless Transfer Port. } \\
\text { The "LEFT" indicator should be illuminated, indicating that the hoist is positioned at the Bagless } \\
\text { Transfer Port. }\end{array}$ & $\begin{array}{l}\text { Visually verify that the hoist trolley } \\
\text { with non-compliant item transfer } \\
\text { stand is positioned over the Bagless } \\
\text { Transfer Port. } \\
\text { Verify that the "LEFT" indicator is } \\
\text { illuminated. }\end{array}$ & & & \\
\hline 10 & $\begin{array}{l}\text { Activate the Trolley/Hoist Pendant 107-PC-07-009A "LOWER" pushbutton to lower the hoist with the } \\
\text { non-compliant item transfer stand until the bottom of the transfer stand is positioned within one foot of } \\
\text { the Drath and Schrader drum mated to the Bagless Transfer Port. } \\
\text { Inspect the position of the transfer stand relative to the drum. }\end{array}$ & $\begin{array}{l}\text { Verify that the transfer stand is } \\
\text { properly centered to allow the } \\
\text { transfer stand to be lowered into the } \\
\text { drum. }\end{array}$ & & & \\
\hline 11 & $\begin{array}{l}\text { Activate the Trolley/Hoist Pendant 107-PC-07-009A "LOWER" pushbutton to slowly lower the non- } \\
\text { compliant item transfer stand into the Drath and Schrader drum. } \\
\text { Continue to lower hoist hook until slack is noted in the hoist chain. }\end{array}$ & $\begin{array}{l}\text { Verify that the non-compliant item } \\
\text { transfer stand is fully seated in the } \\
\text { Drath and Schrader drum. } \\
\text { Verify that slack is noted in the hoist } \\
\text { chain. }\end{array}$ & & & \\
\hline 12 & $\begin{array}{l}\text { Remove the hoist hook from the non-compliant item transfer stand by lowering the hoist until slack is } \\
\text { noted, then raising the hoist. }\end{array}$ & $\begin{array}{l}\text { Verify that the hoist hook is removed } \\
\text { from the non-compliant item transfer } \\
\text { stand }\end{array}$ & $\zeta$ & & \\
\hline 13 & $\begin{array}{l}\text { Activate the Trolley/Hoist Pendant (107-PC-07-009A) "RAISE" pushbutton to slowly raise the hoist } \\
\text { until the hoist is fully raised. } \\
\text { The Trolley/Hoist Pendant (107-PC-07-009A) "Raised Limit" indicator should be illuminated, } \\
\text { indicating that the hoist is fully raised. }\end{array}$ & $\begin{array}{l}\text { Visually verify that the hoist is fully } \\
\text { raised. } \\
\text { Verify that the Trolley/Hoist Pendant } \\
\text { (107-PC-07-009A) "Raised Limit" } \\
\text { indicator is illuminated. }\end{array}$ & 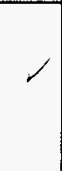 & & kt \\
\hline
\end{tabular}




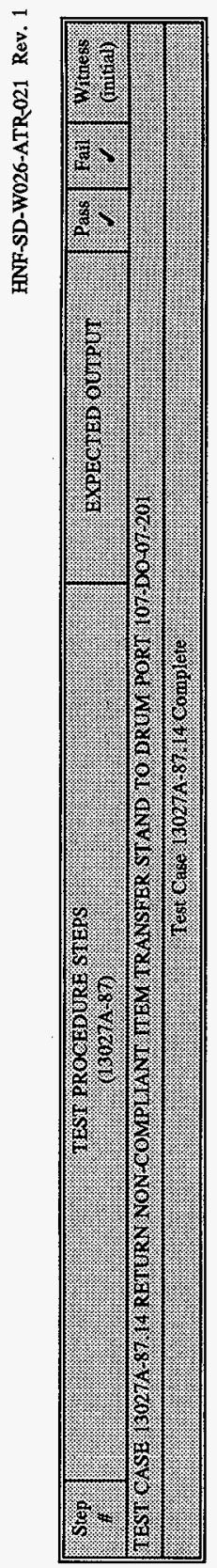

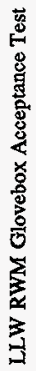

$\frac{j}{v}$

官 
HNF-SD-W026-ATR-021 Rev. 1

\begin{tabular}{|c|c|c|c|c|c|}
\hline Ster & 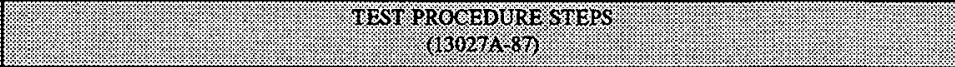 & EXPERTED OYY & Pas & (1). & (rinitia) \\
\hline \multicolumn{6}{|c|}{ 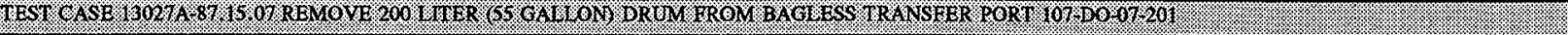 } \\
\hline 1 & $\begin{array}{ll}\text { WARNING: } & \text { The "DRUM TO BAGLESS TRANSFER PORT", "REMOVE TRANSFER STAND } \\
& \text { AND ITEMS FROM DRUM" and "RETURN NON-COMPLIANT ITEM } \\
& \text { TRANSFER STAND TO DRUM" test cases are prerequisites for this test case. Do } \\
& \text { not perform this test case unless the pre-requisite test cases have already been } \\
\text { successfully completed. }\end{array}$ & $\begin{array}{l}\text { Verify that the "MATE DRUM TO } \\
\text { BAGLESS TRANSFER PORT", } \\
\text { "REMOVE TRANSFER STAND } \\
\text { AND ITEMS FROM DRUM", and } \\
\text { "RETURN NON-COMPLIANT } \\
\text { ITEM TRANSFER STAND TO } \\
\text { DRUM" test cases have already been } \\
\text { successfully completed prior to } \\
\text { running this test case. }\end{array}$ & & & \\
\hline 2 & A Drath \& Schrader drum should be mated to the Bagless Transfer Port (107-DO-07-201). & $\begin{array}{l}\text { Verify that a Drath \& Schrader drum } \\
\text { is mated to the Bagless Transfer } \\
\text { Port. }\end{array}$ & $\checkmark$ & & \\
\hline 3 & The Bagless Transfer Port door should be rotated completely open. & $\begin{array}{l}\text { Verify that the Bagless Transfer Port } \\
\text { is open. }\end{array}$ & & & $K q_{2}$ \\
\hline 4 & $\begin{array}{l}\text { The non-compliant item transfer stand should be completely lowered into the Drath \& Schrader drum } \\
\text { mated to the Bagless Transfer Port (107-D0-07-201). }\end{array}$ & $\begin{array}{l}\text { Verify that the non-compliant item } \\
\text { transfer stand is inside the Drath \& } \\
\text { Schrader drum. }\end{array}$ & & & \\
\hline 5 & $\begin{array}{l}\text { The maniputator should be located at park position number } 2 \text { near the } 208 \text { liter ( } 85 \text { gallon) Entry/Exit } \\
\text { Port (107-DO-07-203). The manipulator arms should be parked. } \\
\text { If the manipulator is not in this position, use the manipulator controls to move the manipulator to park } \\
\text { position number } 2 \text { and park the manipulator arms. }\end{array}$ & $\begin{array}{l}\text { Visually verify that the waste } \\
\text { manipulator is at park position } \\
\text { number } 2 \text { with both arms parked. }\end{array}$ & & & \\
\hline 6 & $\begin{array}{l}\text { Confirm that the "LLW RWM GLOVEBOX MAIN MENU" screen is displayed at OIU-12-105B. If a } \\
\text { sub-menu is displayed, press the "MAIN MENU" button to return to the Main Menu. }\end{array}$ & $\begin{array}{l}\text { Verify that the "LLW RWM } \\
\text { GLOVBBOX MAIN MENU" screen } \\
\text { is displayed at OIU-12-105B. }\end{array}$ & & & $k / 2$ \\
\hline 7 & $\begin{array}{l}\text { Press the "PORT DO-07-201 MENU" button from the "LLW RWM GLOVEBOX MAIN MENU" } \\
\text { screen at OIU-12-105B. }\end{array}$ & $\begin{array}{l}\text { Verify that the "PORT DO-07-201 } \\
\text { MENU" screen is displayed. }\end{array}$ & $\checkmark$ & & +1 \\
\hline
\end{tabular}


HNF-SD-W026-ATR-021 Rev. 1

\begin{tabular}{|c|c|c|c|c|c|}
\hline Step & (3) & 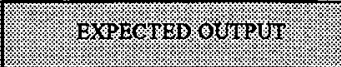 & Pras: & garia & 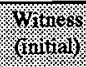 \\
\hline \multicolumn{6}{|c|}{ 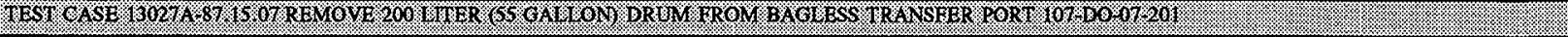 } \\
\hline \multicolumn{6}{|c|}{ 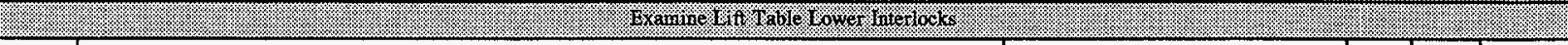 } \\
\hline 8 & $\begin{array}{l}\text { Attempt to move the } 208 \text { liter ( } 55 \text { gallon) Bagless Transfer Port lift table (107-LT-09-201F) by } \\
\text { activating the lift table "LOWER" pushbutton at the lift table local control pedestal (107-PC-09-201F). } \\
\text { The Bagless Transfer Port should be open with a drum mated to this port. Because the port is not } \\
\text { closed and locked, the "LOWER" pushbutton at the lift table local control pedestal should be disabled } \\
\text { and have no effect on the lift table. }\end{array}$ & $\begin{array}{l}\text { Verify that activating the "LOWER" } \\
\text { pushbutton has no effect on the lift } \\
\text { table. }\end{array}$ & & & KV \\
\hline 9 & $\begin{array}{l}\text { Attempt to move the } 200 \text { liter (55 gallon) Bagless Transfer Port lift table (107-LT-09-201F) roller } \\
\text { conveyors by activating the lift table "FORWARD" and "REVERSE" pushbuttons at the lift table local } \\
\text { control pedestal (107-PC-09-201F). } \\
\text { Because the port is not closed and locked, the "FORWARD" and "REVERSE" pushbuttons at the lift } \\
\text { table local control pedestal should be disabled and have no effect on the lift table. }\end{array}$ & $\begin{array}{l}\text { Verify that activating the } \\
\text { "FORWARD" and "REVERSE" } \\
\text { pushbutton has no effect on the lift } \\
\text { table. }\end{array}$ & & & $k n$ \\
\hline
\end{tabular}


HNF-SD-W026-ATR-021 Rev. 1

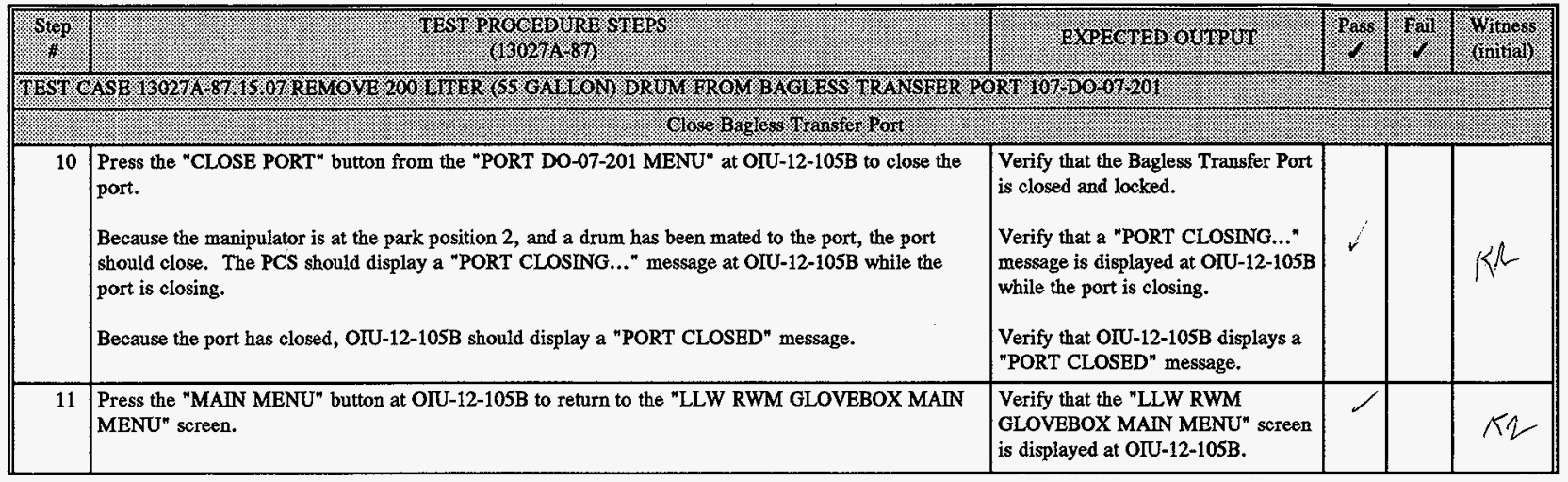




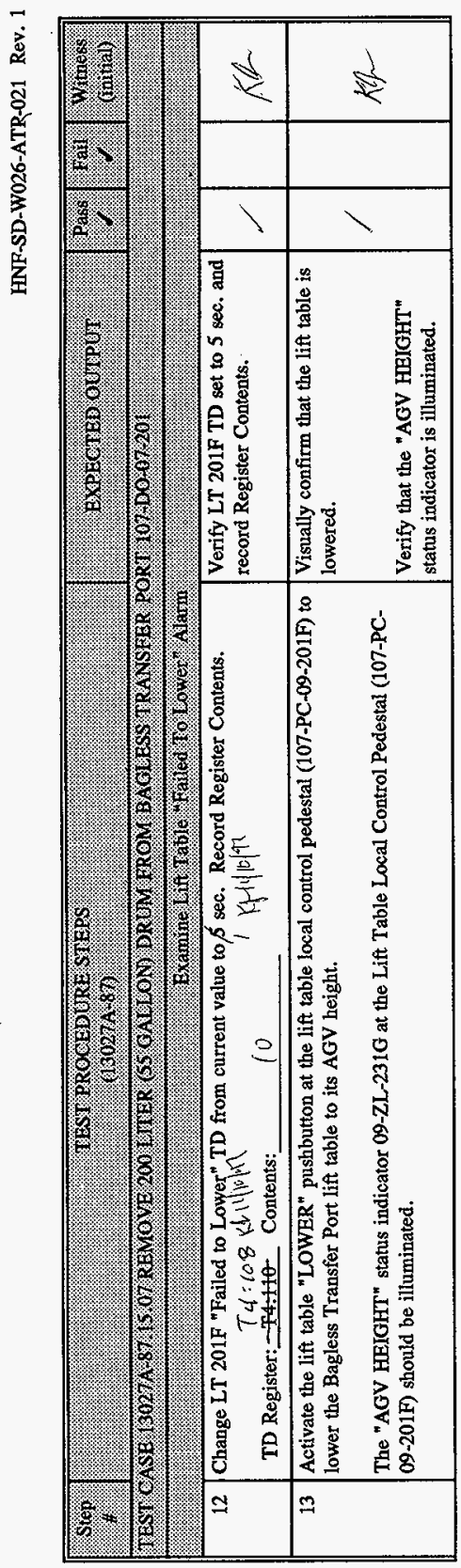




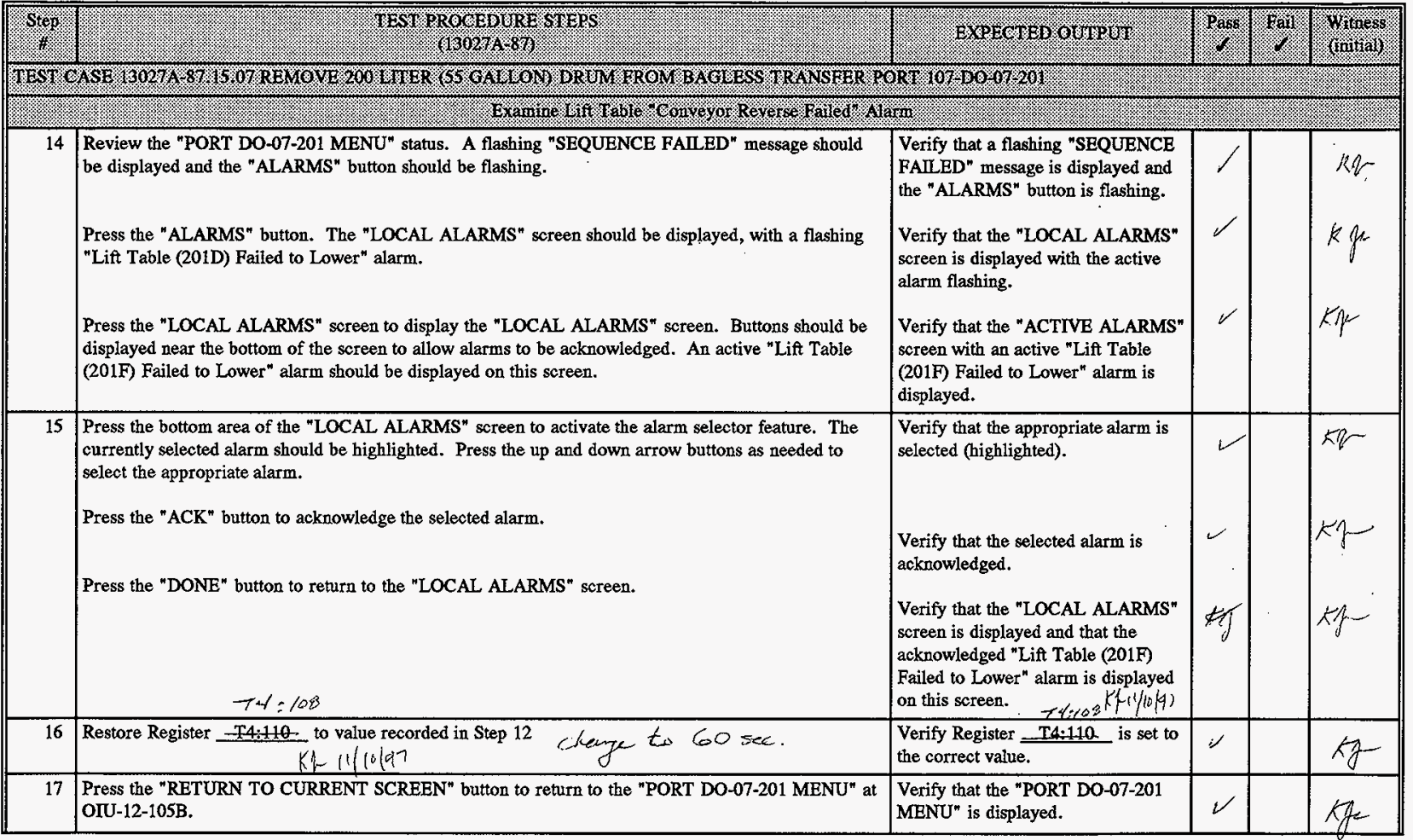




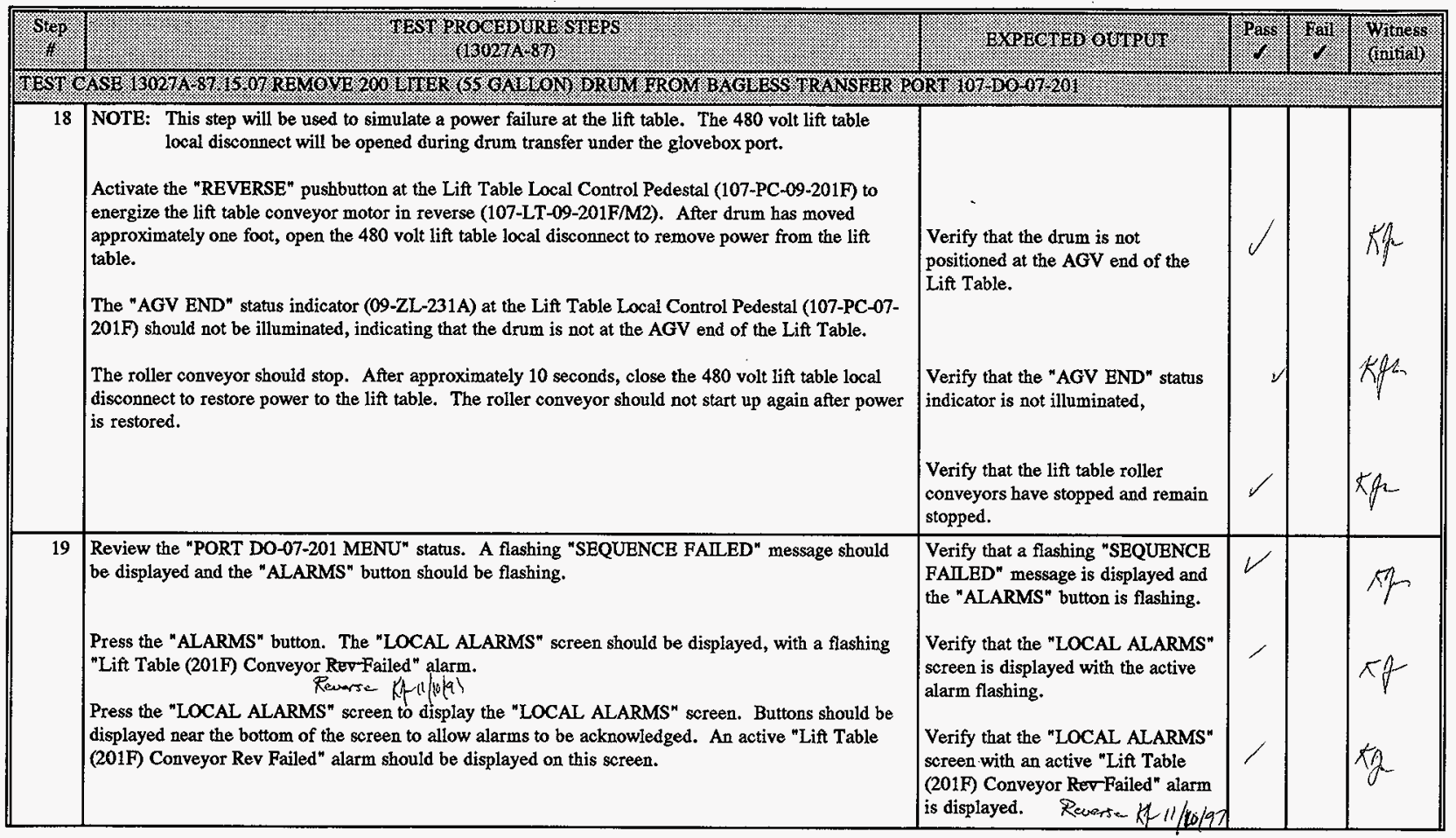


HNF-SD-W026-ATR-021 Rev. 1

\begin{tabular}{|c|c|c|c|c|c|}
\hline Stition: & UEST RROCEDURE SIERS & EXPECTEDOUTPUT & Pass & Fail & Winivess \\
\hline \multicolumn{6}{|c|}{ 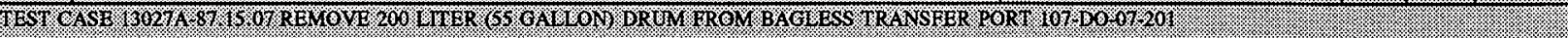 } \\
\hline 20 & $\begin{array}{l}\text { Press the bottom area of the "LOCAL ALARMS" screen to activate the alarm selector feature. The } \\
\text { currently selected alarm should be highlighted. Press the up and down arrow buttons as needed to } \\
\text { select the appropriate alarm. } \\
\text { Press the "ACK" button to acknowledge the selected alarm. } \\
\text { Press the "DONE" button to return to the "LOCAL ALARMS" screen. }\end{array}$ & $\begin{array}{l}\text { Verify that the appropriate alarm is } \\
\text { selected (highlighted). } \\
\text { Verify that the selected alarm is } \\
\text { acknowledged. } \\
\text { Verify that the "LOCAL ALARMS" } \\
\text { screen is displayed and that the } \\
\text { acknowledged "Lift Table (201F) } \\
\text { Conveyor Rev Failed" alarm is } \\
\text { displayed on this screen. }\end{array}$ & $\mathscr{L}$ & & $\sigma$ \\
\hline 21 & $\begin{array}{l}\text { Press the "RETURN TO CURRENT SCREEN" button to return to the "PORT DO-07-201 MENU" at } \\
\text { 107-OIU-12-105B. }\end{array}$ & $\begin{array}{l}\text { Verify that the "PORT DO-07-201 } \\
\text { MENU" is displayed and the screen } \\
\text { status displays "Sequence failed". }\end{array}$ & $\mathcal{J}$ & & \\
\hline 22 & $\begin{array}{l}\text { Activate the "REVERSE" pushbutton at the Lift Table Local Control Pedestal (107-PC-09-201F) to } \\
\text { energize the lift table conveyor motor in reverse (107-LT-09-201F/M2) until the drum is at the AGV } \\
\text { end of the Lift Table. } \\
\text { The "AGV END" status indicator (09-ZL-231A) at the Lift Table Local Control Pedestal (107-PC-07- } \\
\text { 201F) should be illuminated, indicating that the drum is at the AGV end of the Lift Table. }\end{array}$ & $\begin{array}{l}\text { Verify that the drum is at the AGV } \\
\text { end of the Lift Table. } \\
\text { Verify that the "AGV END" status } \\
\text { indicator (09-ZL-231A) is } \\
\text { illuminated. }\end{array}$ & $\mathscr{V}$ & & $K A$ \\
\hline & 1. & & & & \\
\hline
\end{tabular}




\begin{tabular}{|c|c|c|c|c|c|}
\hline 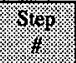 & 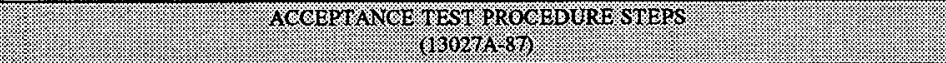 & 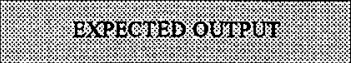 & rass & \%al & Wintives: \\
\hline \multicolumn{6}{|c|}{ 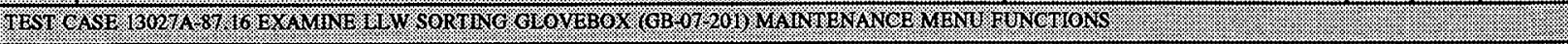 } \\
\hline \multicolumn{6}{|c|}{ 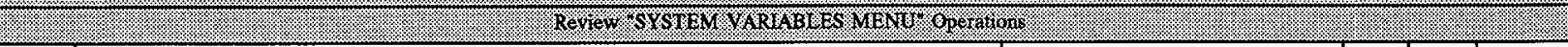 } \\
\hline 1 & $\begin{array}{l}\text { Press the "SYSTEM VARIABLES" button from the "SORTING GLOVEBOX MAINTENANCE } \\
\text { MAIN MENU" at OIU-12-105B. }\end{array}$ & $\begin{array}{l}\text { Verify that the "SYSTEM } \\
\text { VARIABLES" button has been } \\
\text { pressed. }\end{array}$ & $\checkmark$ & & \\
\hline 2 & The "SYSTEM VARIABLES MENU" should be displayed at OIU-12-105B. & $\begin{array}{l}\text { Verify that the "SYSTEM } \\
\text { VARIABLES MENU" is displayed. }\end{array}$ & $\checkmark$ & & \\
\hline 3 & $\begin{array}{l}\text { Press the "SET SCREEN CONTRAST" button from the "SYSTEM VARIABLES MENU" at OIU-12- } \\
\text { 105B. }\end{array}$ & $\begin{array}{l}\text { Verify that the "SET SCREEN } \\
\text { CONTRAST" button has been } \\
\text { pressed. }\end{array}$ & $\checkmark$ & & KhL \\
\hline 4 & The "SET SCREEN CONTRAST" screen should be displayed at OIU-12-105B. & $\begin{array}{l}\text { Verify that the "SET SCREEN } \\
\text { CONTRAST" screen is displayed. }\end{array}$ & $V$ & & $K o$ \\
\hline 5 & A numeric keypad with "ENTER" key should be displayed to allow system values to be modified. & $\begin{array}{l}\text { Verify that a numeric keypad with } \\
\text { "ENTER" key is displayed. }\end{array}$ & $V$ & & $\mathrm{~kg}$ \\
\hline 6 & $\begin{array}{l}\text { Using the keypad, set the System Screen Contrast to "3" and press the "ENTER" key. } \\
\text { Then Press "DONEA KU Ulok? }\end{array}$ & $\begin{array}{l}\text { Verify that the System Screen } \\
\text { Contrast has been set to "3" }\end{array}$ & $\checkmark$ & & \\
\hline 7 & The "SYSTEM VARIABLES MENU" should be displayed at OIU-12-105B. & $\begin{array}{l}\text { Verify that the "SYSTEM } \\
\text { VARIABLES MENU" is displayed. }\end{array}$ & $V$ & & $K$ \\
\hline 8 & The value displayed on the "SET SCREEN CONTRAST" button should be "3" & $\begin{array}{l}\text { Verify that the "SET SCREEN } \\
\text { CONTRAST" value is "3" }\end{array}$ & $\checkmark$ & & $\times 2$ \\
\hline 9 & Press the "SET DAY" button from the "SYSTEM VARIABLES MENU" at OIU-12-105B. & $\begin{array}{l}\text { Verify that the "SET DAY" button } \\
\text { has been pressed. }\end{array}$ & $\checkmark$ & & KL \\
\hline 10 & The "SET DAY" screen should be displayed at OIU-12-105B. & $\begin{array}{l}\text { Verify that the "SET DAY" screen is } \\
\text { displayed. }\end{array}$ & $\checkmark$ & & $K \notin$ \\
\hline 11 & A numeric keypad with "ENTER" key should be displayed to allow system values to be modified. & $\begin{array}{l}\text { Verify that a numeric keypad with } \\
\text { "ENTER" key is displayed. }\end{array}$ & $\checkmark$ & & $K \mathbb{L}$ \\
\hline 12 & Using the keypad, set the System Day to "3" and press the "ENTER" key. & $\begin{array}{l}\text { Verify that the System Day has been } \\
\text { set to "3" }\end{array}$ & $V$ & & $K /$ \\
\hline 13 & Press the "DONE" key. & $\begin{array}{l}\text { Verify that the "DONE" key has } \\
\text { been pressed. }\end{array}$ & $V$ & & $k q$ \\
\hline
\end{tabular}


HNF-SD-W026-ATR-021 Rev. 1

\begin{tabular}{|c|c|c|c|c|c|}
\hline 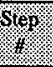 & f & R. & Sass: & Fall: & Winess: \\
\hline 14 & The "SYSTEM VARIABLES MENU" should be displayed at OIU-12-105B. & $\begin{array}{l}\text { Verify that the "SYSTEM } \\
\text { VARIABLES MENU" is displayed. }\end{array}$ & $\checkmark$ & & $K R$ \\
\hline 15 & The value displayed on the "SET DAY" button should be "3" & $\begin{array}{l}\text { Verify that the "SET DAY" value is } \\
\text { "3" }\end{array}$ & 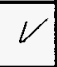 & & $K$ \\
\hline 16 & Press the "SET MONTH" button from the "SYSTEM VARIABLES MENU" at OIU-12-105B. & $\begin{array}{l}\text { Verify that the "SET MONTH" } \\
\text { button has been pressed. }\end{array}$ & $\nu$ & & \\
\hline 17 & The "SET MONTH" screen should be displayed at OIU-12-105B. & $\begin{array}{l}\text { Verify that the "SET MONTH" } \\
\text { screen is displayed. }\end{array}$ & $\checkmark$ & & e \\
\hline 18 & A numeric keypad with "ENTER" key should be displayed to allow system values to be modified. & $\begin{array}{l}\text { Verify that a numeric keypad with } \\
\text { "ENTER" key is displayed. }\end{array}$ & $\checkmark$ & & \\
\hline 19 & Using the keypad, set the System Month to "3" and press the "ENTER" key. & $\begin{array}{l}\text { Verify that the System Month has } \\
\text { been set to "3" }\end{array}$ & V & & 2 \\
\hline 20 & Press the "DONE" key. & $\begin{array}{l}\text { Verify that the "DONE" key has } \\
\text { been pressed. }\end{array}$ & $\checkmark$ & & \\
\hline 21 & The "SYSTEM VARIABLES MENU" should be displayed at OIU-12-105B. & $\begin{array}{l}\text { Verify that the "SYSTEM } \\
\text { VARIABLES MENU" is displayed. }\end{array}$ & $\checkmark$ & & $k \eta$ \\
\hline 22 & The value displayed on the "SET MONTH" button should be "3" & $\begin{array}{l}\text { Verify that the "SET MONTH" } \\
\text { value is " } 3 \text { " }\end{array}$ & $\nu$ & & $K A$ \\
\hline 23 & Press the "SET YEAR" button from the "SYSTEM VARIABLES MENU" at OIU-12-105B. & $\begin{array}{l}\text { Verify that the "SET YEAR" button } \\
\text { has been pressed. }\end{array}$ & $\checkmark$ & & $k \gamma$ \\
\hline 24 & The "SET YEAR" screen should be displayed at OIU-12-105B. & $\begin{array}{l}\text { Verify that the "SET YEAR" screen } \\
\text { is displayed. }\end{array}$ & $V$ & & \\
\hline 25 & A numeric keypad with "ENTER" key should be displayed to allow system values to be modified. & $\begin{array}{l}\text { Verify that a numeric keypad with } \\
\text { "ENTER" key is displayed. }\end{array}$ & $V$ & & $K \ell$ \\
\hline 26 & Using the keypad, set the System Year to "3" and press the "ENTER" key. & $\begin{array}{l}\text { Verify that the System Year has been } \\
\text { set to "3" }\end{array}$ & $\checkmark$ & & $1<2$ \\
\hline 27 & Press the "DONE" key. & $\begin{array}{l}\text { Verify that the "DONE" key has } \\
\text { been pressed. }\end{array}$ & $\checkmark$ & & $k q$ \\
\hline 28 & The "SYSTEM VARIABLES MENU" should be displayed at OIU-12-105B. & $\begin{array}{l}\text { Verify that the "SYSTEM } \\
\text { VARIABLES MENU" is displayed. }\end{array}$ & $V$ & & 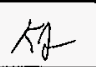 \\
\hline
\end{tabular}


HNF-SD-W026-ATR-021 Rev. 1

\begin{tabular}{|c|c|c|c|c|c|}
\hline Sis: & 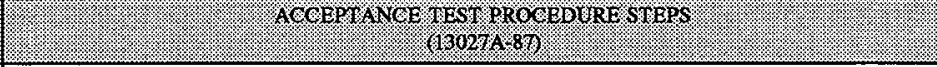 & EXPECTED OOYPSP & Prs: & fint: & Winitines) \\
\hline 29 & The value displayed on the "SET YEAR" button should be "3" & $\begin{array}{l}\text { Verify that the "SET YEAR" value } \\
\text { is "3" }\end{array}$ & $\checkmark$ & & $K \mu$ \\
\hline 30 & Press the "SET HOURS" button from the "SYSTEM VARIABLES MENU" at OIU-12-105B. & $\begin{array}{l}\text { Verify that the "SET HOURS" } \\
\text { button has been pressed. }\end{array}$ & $\checkmark$ & & 52 \\
\hline 31 & The "SET HOURS" screen should be displayed at OIU-12-105B. & $\begin{array}{l}\text { Verify that the "SET HOURS" } \\
\text { screen is displayed. }\end{array}$ & $\checkmark$ & & \\
\hline 32 & A numeric keypad with "ENTER" key should be displayed to allow system values to be modified. & $\begin{array}{l}\text { Verify that a numeric keypad with } \\
\text { "ENTER" key is displayed. }\end{array}$ & $\checkmark$ & & \\
\hline 33 & Using the keypad, set the System Hours to "15" and press the "ENTER" key. & $\begin{array}{l}\text { Verify that the System Hours have } \\
\text { been set to " } 15^{n}\end{array}$ & $\checkmark$ & & \\
\hline 34 & Press the "DONE" key. & $\begin{array}{l}\text { Verify that the "DONE" key has } \\
\text { been pressed. }\end{array}$ & 5 & & $\kappa 2$ \\
\hline 35 & The "SYSTEM VARIABLES MENU" should be displayed at OIU-12-105B. & $\begin{array}{l}\text { Verify that the "SYSTEM } \\
\text { VARIABLES MENU" is displayed. }\end{array}$ & $\checkmark$ & & $\kappa 2$ \\
\hline 36 & $\begin{array}{l}\text { The value displayed on the "SET HOURS" button should be "15" } \\
\text { NOTE: This value should represent } 3 \text { p.m. in the afternoon. If the value does not represent } 3 \text { p.m., } \\
\text { then this step fails. }\end{array}$ & $\begin{array}{l}\text { Verify that the "SET HOURS" value } \\
\text { is "15" }\end{array}$ & $\gamma$ & & Ky \\
\hline 37 & Press the "SET MINUTES" button from the "SYSTEM VARIABLES MENU" at OrU-12-105B. & $\begin{array}{l}\text { Verify that the "SET MINUTES" } \\
\text { button has been pressed. }\end{array}$ & $\checkmark$ & & \\
\hline 38 & The "SET MINUTES" screen should be displayed at OIU-12-105B. & $\begin{array}{l}\text { Verify that the "SET MINUTES" } \\
\text { screen is displayed. }\end{array}$ & $V$ & & $x \geqslant$ \\
\hline 39 & A numeric keypad with "ENTER" key should be displayed to ailow system values to be modified. & $\begin{array}{l}\text { Verify that a numeric keypad with } \\
\text { "ENTER" key is displayed. }\end{array}$ & $\checkmark$ & & to \\
\hline 40 & Using the keypad, set the System Minutes to "3" and press the "ENTER" key. & $\begin{array}{l}\text { Verify that the System Minutes have } \\
\text { been set to " } 3^{\prime \prime}\end{array}$ & $\checkmark$ & & $5 g$ \\
\hline 41 & Press the "DONE" key. & $\begin{array}{l}\text { Verify that the "DONE" key has } \\
\text { been pressed. }\end{array}$ & $\checkmark$ & & $K 2$ \\
\hline 42 & The "SYSTEM VARIABLES MENU" should be displayed at OIU-12-105B. & $\begin{array}{l}\text { Verify that the "SYSTEM } \\
\text { VARIABLES MENU" is displayed. }\end{array}$ & $\checkmark$ & & K.1. \\
\hline 43 & $\begin{array}{l}\text { The value displayed on the "SET MINUTES" button should start at "3" and then advance. (e.g., } \\
\text { System Minutes will change each minute.) }\end{array}$ & $\begin{array}{l}\text { Verify that the initial "SET } \\
\text { MINUTES" value is "3" }\end{array}$ & $L$ & & tz \\
\hline
\end{tabular}


HNF-SD-W026-ATR-021 Rev. 1

\begin{tabular}{|c|c|c|c|c|c|}
\hline sies. & 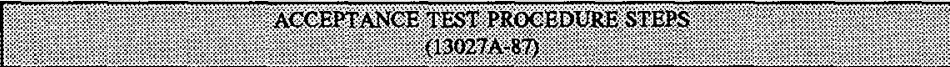 & 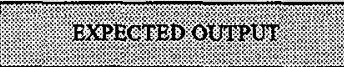 & Pass: & s. & Witinitis: \\
\hline 44 & Press the "SET SECONDS" button from the "SYSTEM VARIABLES MENU" at OIU-12-105B. & $\begin{array}{l}\text { Verify that the "SET SECONDS" } \\
\text { button has been pressed. }\end{array}$ & $\checkmark$ & & \\
\hline 45 & The "SET SBCONDS" screen should be displayed at OIU-12-105B. & $\begin{array}{l}\text { Verify that the "SET SECONDS" } \\
\text { sereen is displayed. }\end{array}$ & $V$ & & $\mathrm{KO}$ \\
\hline 46 & A numeric keypad with "ENTER" key should be displayed to allow system values to be modified. & $\begin{array}{l}\text { Verify that a numeric keypad with } \\
\text { "ENTER" key is displayed. }\end{array}$ & $\checkmark$ & & $k$ \\
\hline 47 & Using the keypad, set the System Seconds to "3" and press the "ENTER" key. & $\begin{array}{l}\text { Verify that the System Seconds have } \\
\text { been set to "3" }\end{array}$ & 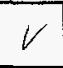 & & Kq \\
\hline 48 & Press the "DONE" key. & $\begin{array}{l}\text { Verify that the "DONE" key has } \\
\text { been pressed. }\end{array}$ & $\checkmark$ & & $\mathrm{kg}$ \\
\hline 49 & The "SYSTEM VARIABLES MENU" should be displayed at OIU-12-105B. & $\begin{array}{l}\text { Verify that the "SYSTEM } \\
\text { VARIABLES MENU" is displayed. }\end{array}$ & $\checkmark$ & & $k \mathbb{R}$ \\
\hline 50 & $\begin{array}{l}\text { The value displayed on the "SET SECONDS" button should start at "3"and then rapidly advance (e.g., } \\
\text { System Seconds will change each second.) }\end{array}$ & $\begin{array}{l}\text { Verify that the "SET SECONDS" } \\
\text { initial value is " } 3 \text { " }\end{array}$ & $\alpha$ & & $k \mathbb{L}$ \\
\hline
\end{tabular}


它

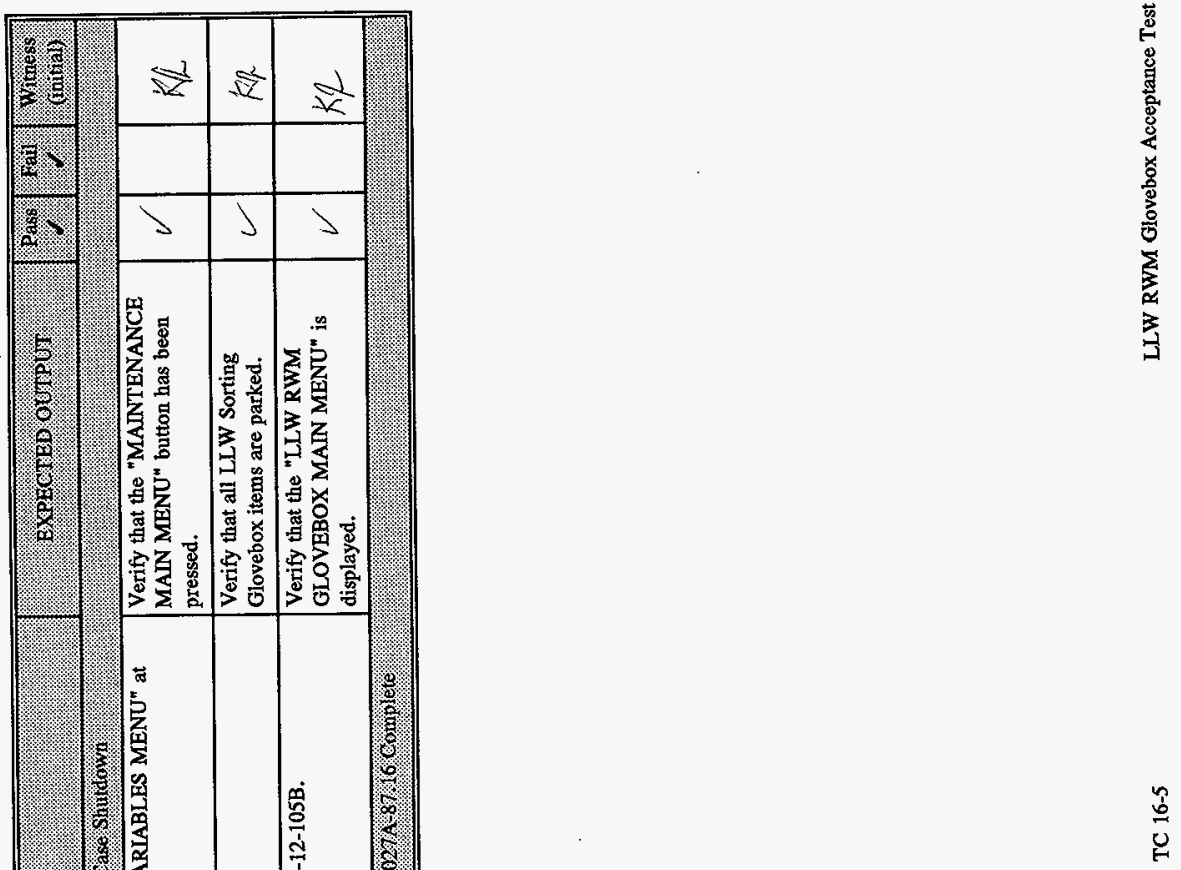


HNF-SD-W026-ATR-021 Rev. 1

\begin{tabular}{|c|c|c|c|c|c|}
\hline step & 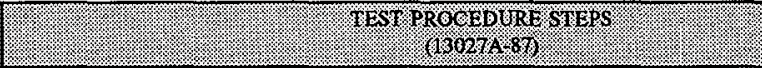 & 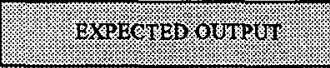 & Parso & Fari: & Witries \\
\hline \multicolumn{6}{|c|}{ 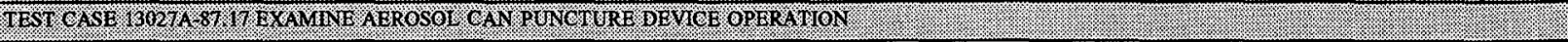 } \\
\hline \multicolumn{6}{|c|}{ NOTE: This test case will verify that the Aerosol Can Puncture device functions as per design requirements. } \\
\hline 1 & Install aerosol can puncture device filter and collection bottle. & $\begin{array}{l}\text { Verify aerosol can puncture device } \\
\text { filter and collection bottle are } \\
\text { installed. }\end{array}$ & $V$ & & 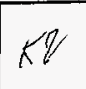 \\
\hline 2 & Insert an Aerosol Can (pressurized) into the holder. up side Clown & $\begin{array}{l}\text { Verify a pressurized aerosol can is } \\
\text { installed in the holder. }\end{array}$ & $\mathscr{V}$ & & $K_{f}$ \\
\hline 3 & Clamp the lid in place. & Verify the lid is in place. & $\check{\nu}$ & & $\sqrt{4}+2$ \\
\hline 4 & Puncture the side of the can. & Verify the can is punctured. & $V$ & & (Sth \\
\hline 5 & Verify the puncture by the collection of the can contents in the collection chamber. & $\begin{array}{l}\text { Verify the collection chamber } \\
\text { collects the contents of the aerosol } \\
\text { can. }\end{array}$ & 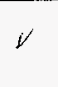 & & $\kappa / 2$ \\
\hline 6 & Remove the can. & & 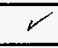 & & $k 2$ \\
\hline 7 & Remove aerosol can puncture device filter and collection bottle. & & $V$ & & $x$ \\
\hline & 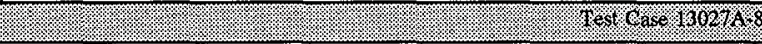 & & & & \\
\hline
\end{tabular}




\begin{tabular}{|c|c|c|c|c|c|}
\hline sies? & WEST PROGEOURE STEPS & 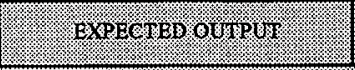 & (e) & (6) & (rinitinil) \\
\hline \multicolumn{6}{|c|}{ 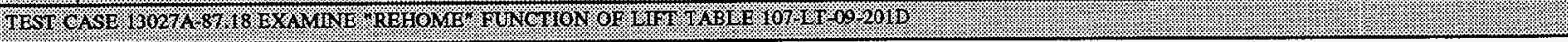 } \\
\hline \multicolumn{6}{|c|}{ NOTE: This test case will verify that the rehome function associated with Lift Table 107-LT-09-201D SERVO control is implemented and functions from OIU-105B. } \\
\hline 1 & Remove/verify removed drum from Lift Table 107-LT-09-201D. & $\begin{array}{l}\text { Verify no drum is present on 107- } \\
\text { LT-09-201D. }\end{array}$ & $\checkmark$ & & $K 0$ \\
\hline 2 & 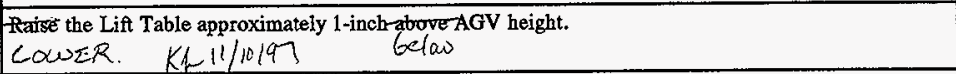 & $\begin{array}{l}\text { Verify Lift Table 107-LT-09-201D is } \\
\text { one inch above AGV Height. }\end{array}$ & I & & Kf \\
\hline 3 & Rehome Lift Table using OIU "REHOME LIFT TABLE LT-09-201D" function. & & $\checkmark$ & & $k 2$ \\
\hline 4 & Verify Lift Table is rehomed. & $\begin{array}{l}\text { Verify that Lift Table moves to AGV } \\
\text { height. } \\
\text { Verify Lift Table rollers are } \\
27 \pm 1 / 8 \text { " above floor. } Z 7^{\prime \prime} \\
\text { Verify "AGV HEIGHT" indicator on } \\
107-P C-09-201 D \text { is illuminated. }\end{array}$ & , & & $\begin{array}{l}K / 2 \\
K 2\end{array}$ \\
\hline & 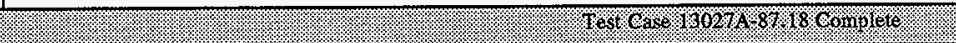 & & & & \\
\hline
\end{tabular}


HNF-SD-W026-ATR-021 Rev. 1

\begin{tabular}{|c|c|c|c|c|c|}
\hline Step & 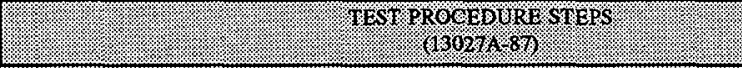 & EXPECTED OWWP & ras. & 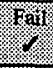 & (nitivaly \\
\hline \multicolumn{6}{|c|}{ 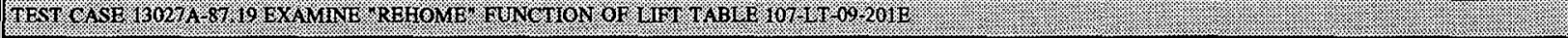 } \\
\hline \multicolumn{6}{|c|}{ NOTE: This test case will verify that the rehome function associated with Lift Table 107-LT-09-201E SERVO control is implemented and functions from OIU-105B. } \\
\hline 1 & Remove/verify removed drum from Lift Table 107-LT-09-201E. & $\begin{array}{l}\text { Verify no drum is present on 107- } \\
\text { LT-09-201E. }\end{array}$ & $\checkmark$ & & \\
\hline 2 & Raise the Lift Table approximately 1-inch above AGV height. & $\begin{array}{l}\text { Verify Lift Table 107-LT-09-201E is } \\
\text { one inch above AGV Height. }\end{array}$ & $\checkmark$ & & \\
\hline 3 & Rehome Lift Table using OIU "REHOME LIFT TABLE LT-09-201E" function. & & $\bar{V}$ & & \\
\hline 4 & Verify Lift Table is rehomed. & $\begin{array}{l}\text { Verify that Lift Table moves to AGV } \\
\text { height. } \\
\text { Verify Lift Table rollers are } \\
27 \pm 1 / 8 \text { " above floor. } 26 \% " \\
\text { Verify "AGV HEIGHT" indicator on } \\
107-P C=09-201 \mathrm{E} \text { is illuminated. }\end{array}$ & $\alpha$ & & $\begin{array}{l}K \gamma \\
k j\end{array}$ \\
\hline & 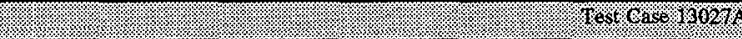 & & & & \\
\hline
\end{tabular}


HNF-SD-W026-ATR-021 Rev. 1

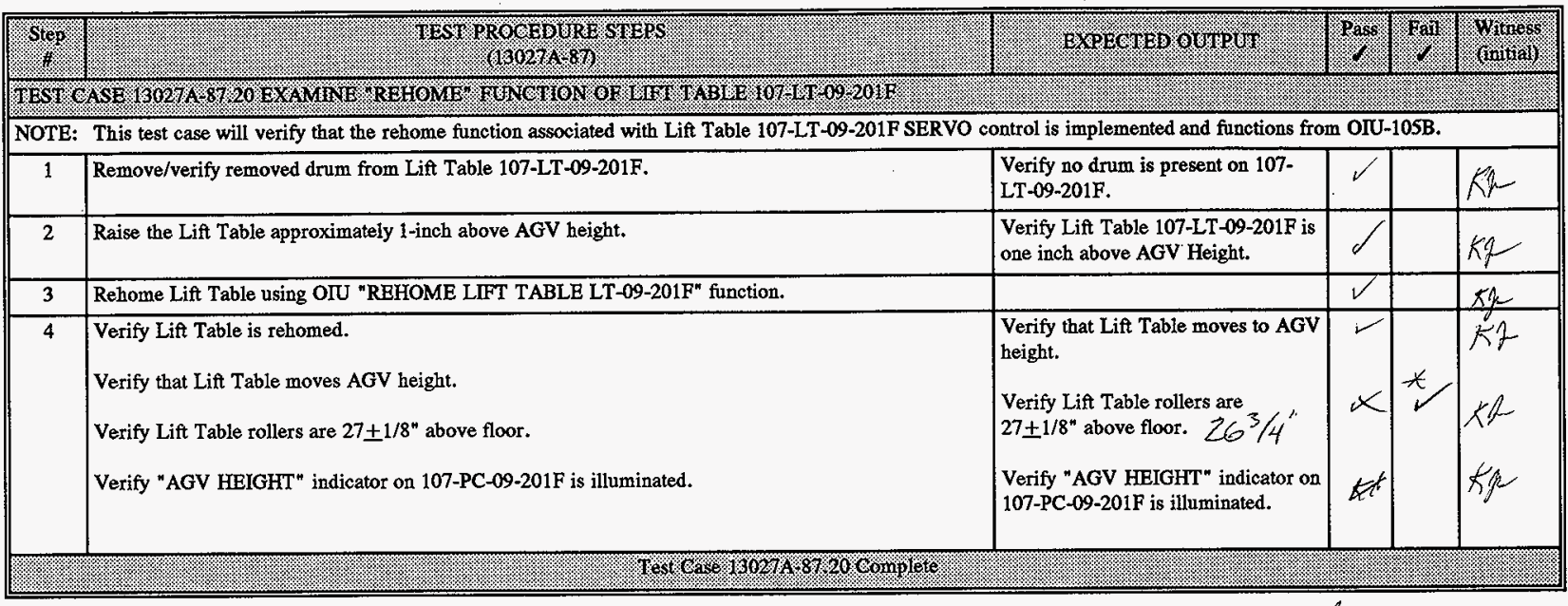

$$
\text { * Rebert ok kf }
$$


HNF-SD-W026-ATR-021 Rev. 1

\begin{tabular}{|c|c|c|c|c|c|}
\hline 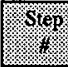 & 1. & 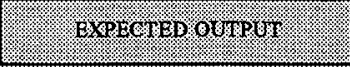 & passos & Jitis & (chitial) \\
\hline \multicolumn{6}{|c|}{ 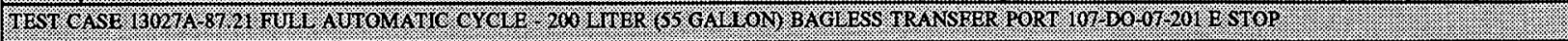 } \\
\hline 1 & $\begin{array}{l}\text { The "LLW RWM GLOVEBOX MAIN MENU" should be displayed on the OIU screen. If it is not, } \\
\text { switch from the presently displayed menu to the "LLW RWM GLOVEBOX MAIN MENU". }\end{array}$ & $\begin{array}{l}\text { Verify that the "LLW RWM } \\
\text { GLOVEBOX MAIN MENU" is } \\
\text { displayed. }\end{array}$ & & & $\mathrm{Kit}$ \\
\hline 2 & $\begin{array}{l}\text { Press "PORT DO-07-201 MENU" on the "LLW RWM GLOVEBOX MAIN MENU". } \\
\text { The "PORT DO-07-201 MENU" should be displayed. }\end{array}$ & $\begin{array}{l}\text { Verify that the "PORT DO-07-201 } \\
\text { MENU" is displayed. }\end{array}$ & $\sqrt{ }$ & & \\
\hline 3 & $\begin{array}{l}\text { The Bagless Transfer port control console is still in manual mode. Press " } \mathrm{K} 2 \text { " to select Automatic } \\
\text { Mode. }\end{array}$ & $\begin{array}{l}\text { Verify that the Bagless Transfer port } \\
\text { control console is in the Full } \\
\text { Automatic Mode. }\end{array}$ & $\checkmark$ & & \\
\hline 4 & $\begin{array}{l}\text { Visually inspect the Glovebox area. Confirm that the bagless transfer port that will be tested and all } \\
\text { items associated with this glovebox are ready for operation and that no debris or other foreign matter is } \\
\text { present that would disrupt testing. }\end{array}$ & $\begin{array}{l}\text { Verify that the bagless transfer port } \\
\text { has been prepared for operation and } \\
\text { testing. }\end{array}$ & $\checkmark$ & & \\
\hline$\overline{5}$ & $\begin{array}{l}\text { Prepare one empty } 208 \text { liter ( } 55 \text { gallon) Drath and Schrader drum with Cross Lid. This type of drum } \\
\text { is designed to function with the Bagless Transfer Port. }\end{array}$ & $\begin{array}{l}\text { Verify that a Drath and Schrader } \\
\text { drum with lid is available for testing. }\end{array}$ & $V$ & & \\
\hline$\overline{6}$ & At control pedestal PC-07-201F place "M/O/N" switch to "NORMAL". & $\begin{array}{l}\text { Verify that "M/O/N" switch is set to } \\
\text { "NORMAL". }\end{array}$ & $\mathscr{L}$ & & \\
\hline$\overline{7}$ & 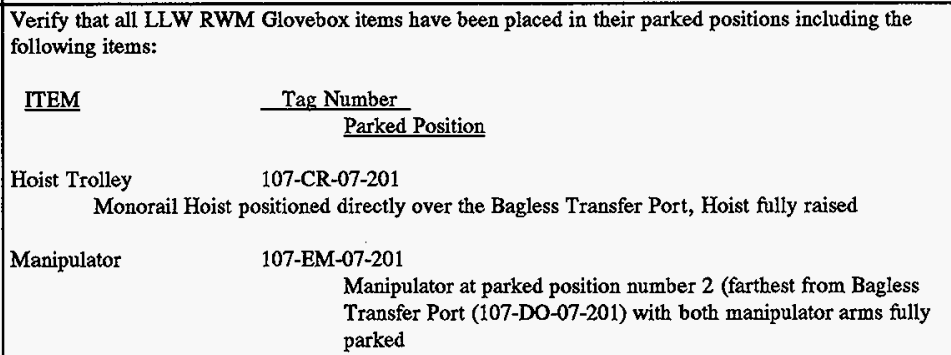 & $\begin{array}{l}\text { Verify that all glovebox items } \\
\text { present have been placed in their } \\
\text { parked positions. }\end{array}$ & 2 & & $\operatorname{tg}$ \\
\hline
\end{tabular}




\begin{tabular}{|c|c|c|c|c|c|}
\hline Siep & TEST PROQEDGRT STEPS & 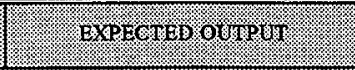 & pasis. & (1) & atrinss \\
\hline \multicolumn{6}{|c|}{ 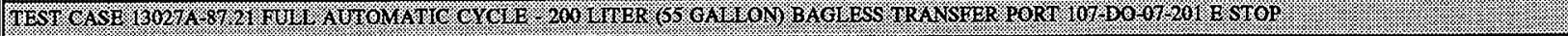 } \\
\hline 8 & $\begin{array}{l}\text { Place a } 208 \text { liter (55 gallon) Drath \& Schrader drum with inner drum lid, transfer stand, } \\
\text { at the AGV end of lift table 107-LT-09-201F such that the drum interrupts the light beam of } \\
\text { photosensor ZS-231F. } \\
\text { The "AGV END" light on the Control Pedestal should be illuminated. } \\
\text { Message "NO DRUM AT LIFT TABLE" should be displayed on the OIU screen. } \\
\text { TRENEOUS STEP }\end{array}$ & $\begin{array}{l}\text { Verify that the drum is interrupting } \\
\text { the light beam of the photosensor. } \\
\text { Verify that the "AGV END" light is } \\
\text { illuminated. } \\
\text { Verify that the "NO DRUM AT } \\
\text { LIFT TABLE" message is displayed. }\end{array}$ & V & & \\
\hline 9 & $\begin{array}{l}\text { Move the drum toward the port far enough so the photosensor light beam has been reestablished. } \\
\text { Message "DRUM AT LIFT TABLE" should be displayed on the OIU screen. } \\
\text { CRRONEUUS STEP }\end{array}$ & $\begin{array}{l}\text { Verify that the drum is no longer } \\
\text { interrupting the light beam of the } \\
\text { photosensor. } \\
\text { Verify that the "DRUM AT LIFT } \\
\text { TABLE" message is displayed. }\end{array}$ & 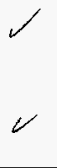 & & \\
\hline 10 & $\begin{array}{l}\text { The "AGV/PANEL" switch on lift table Local Control Pedestal PC-07-201F should be in the } \\
\text { "PANEL" position. If it is in the "AGV" position, place the switeh in the "PANEL" position. }\end{array}$ & $\begin{array}{l}\text { Verify that the switch is in the } \\
\text { "PANEL" position. }\end{array}$ & $\checkmark$ & & \\
\hline 11 & $\begin{array}{l}\text { Press "FORWARD" on Control Pedestal PC-07-201F. } \\
\text { Drum should move forward until centered under the port, motor should automatically de-energize. } \\
\text { The "DRUM UNDER PORT" light on the Control Pedestal should be illuminated. }\end{array}$ & $\begin{array}{l}\text { Verify that the conveyor motor de- } \\
\text { energizes when the drum is centered } \\
\text { under the port. } \\
\text { Verify that the "DRUM UNDER } \\
\text { PORT" light is illuminated. }\end{array}$ & $V$ & & $\begin{array}{l}k f \\
k \gamma\end{array}$ \\
\hline 12 & $\begin{array}{l}\text { Press "RAISE" on Control Pedestal PC-07-201E. } \\
\text { The drum should raise to until the predetermined weight setpoint has been reached and then stop. } \\
\text { The "DRUM IN POSITION" light on the Control Pedestal should be illuminated, indicating that the } \\
\text { predetermined weight setpoint has been reached. } \\
\text { Setpoint te-gt. } 744 \mathrm{ks} \text { actual 740 }\end{array}$ & $\begin{array}{l}\text { Verify that the drum raises and then } \\
\text { stops at the weight setpoint. } \\
\text { Verify that the "DRUM IN } \\
\text { POSITION" light is illuminated. }\end{array}$ & 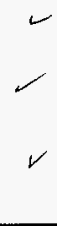 & & th \\
\hline
\end{tabular}




\begin{tabular}{|c|c|c|c|c|c|}
\hline Sters & 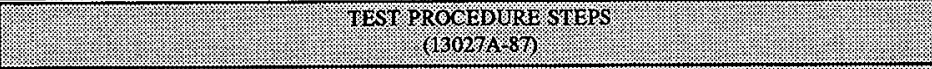 & . & ras. & rat. & Miness \\
\hline \multicolumn{6}{|c|}{ 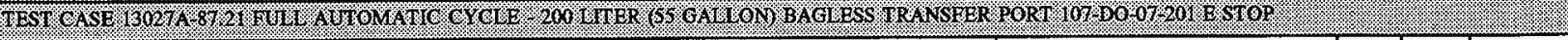 } \\
\hline 13 & $\begin{array}{l}\text { NOTE: When this step is initiated, a series of steps will be performed automatically. } \\
\text { Press "OPEN PORT" on the "PORT DO-07-201 MENU". } \\
\text { Message "PORT OPENING..." should be displayed on the OIU screen. }\end{array}$ & $\begin{array}{l}\text { Verify that the "PORT } \\
\text { OPENING..." message is displayed. }\end{array}$ & $\checkmark$ & & $K A$ \\
\hline 14 & $\begin{array}{l}\text { After the port starts rotating open, place "EMERGENCY STOP" switch 107-HS-201A in the "TRIP" } \\
\text { position. }\end{array}$ & $\begin{array}{l}\text { Verify that the "EMERGENCY } \\
\text { STOP" switch is in the "TRIP" } \\
\text { position. }\end{array}$ & & & \\
\hline$p$ iv & $\begin{array}{l}\text { Verify that the port door stops rotating, holds in place, and the lid remains attached to the door } \\
\text { hilf }\end{array}$ & $\begin{array}{l}\text { Verify that the port door stops } \\
\text { rotating, holds in place, and the lid } \\
\text { remains attached to the door. }\end{array}$ & r & & \\
\hline 116 & 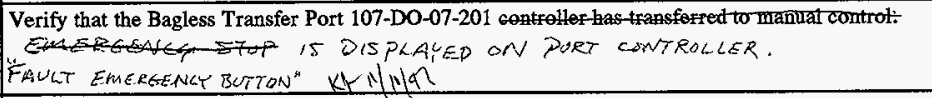 & $\begin{array}{l}\text { Verify that the Bagless Transfer Port } \\
\text { 107-DO-07-201 controller has } \\
\text { transferred to manual control. }\end{array}$ & & & \\
\hline 17 & Reset "EMERGENCY STOP" switch 107-HS-201A. & $\begin{array}{l}\text { Verify "EMERGENCY STOP" } \\
\text { switch is reset. }\end{array}$ & $\nu$ & & $<R$ \\
\hline 18 & 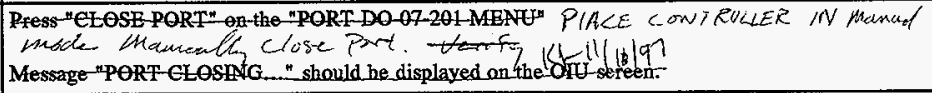 & $\begin{array}{l}\text { Verify that the "NoRT CLOSHG..." } \\
\text { message is displayed. }\end{array}$ & & & \\
\hline 19 & 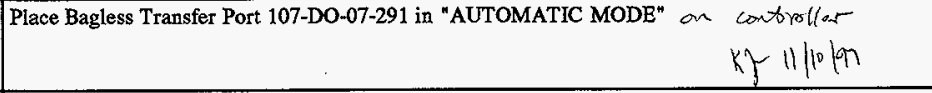 & $\begin{array}{l}\text { Verify that the Bagless Transfer Port } \\
\text { 107-DO-07-201 is in "AUTOMATIC } \\
\text { MODE". }\end{array}$ & & & \\
\hline 20 & $\begin{array}{l}\text { Press "OPEN PORT" on the "PORT DO-07-201 MENU". } \\
\text { Message "PORT OPENING..." should be displayed on the OIU screen. }\end{array}$ & $\begin{array}{l}\text { Verify that the "PORT } \\
\text { OPENING..." message is displayed. }\end{array}$ & $r$ & & \\
\hline
\end{tabular}

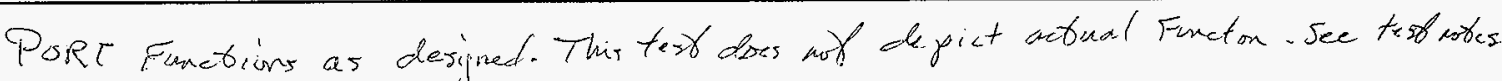

$$
\begin{aligned}
& \text { Miliolon }
\end{aligned}
$$




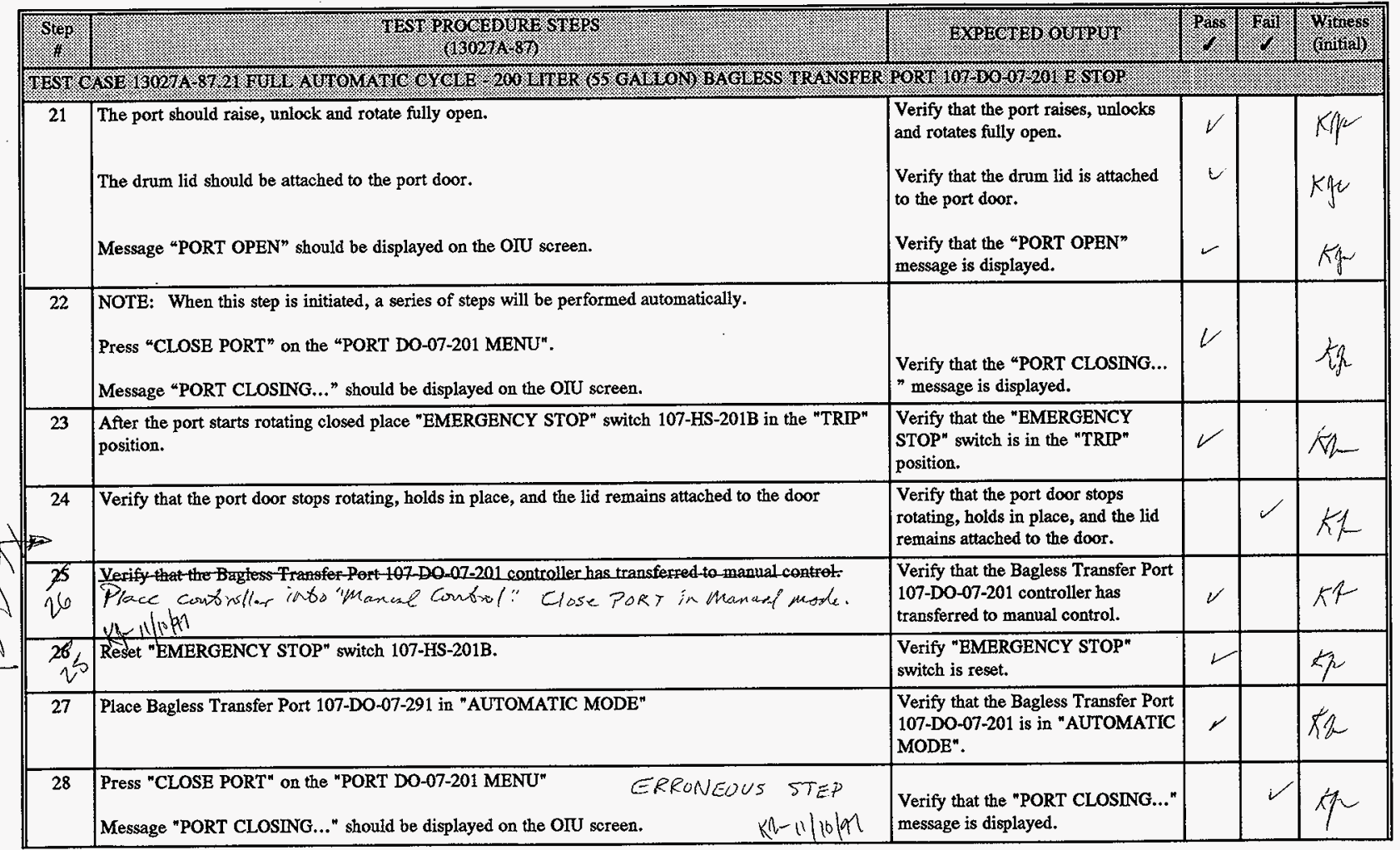




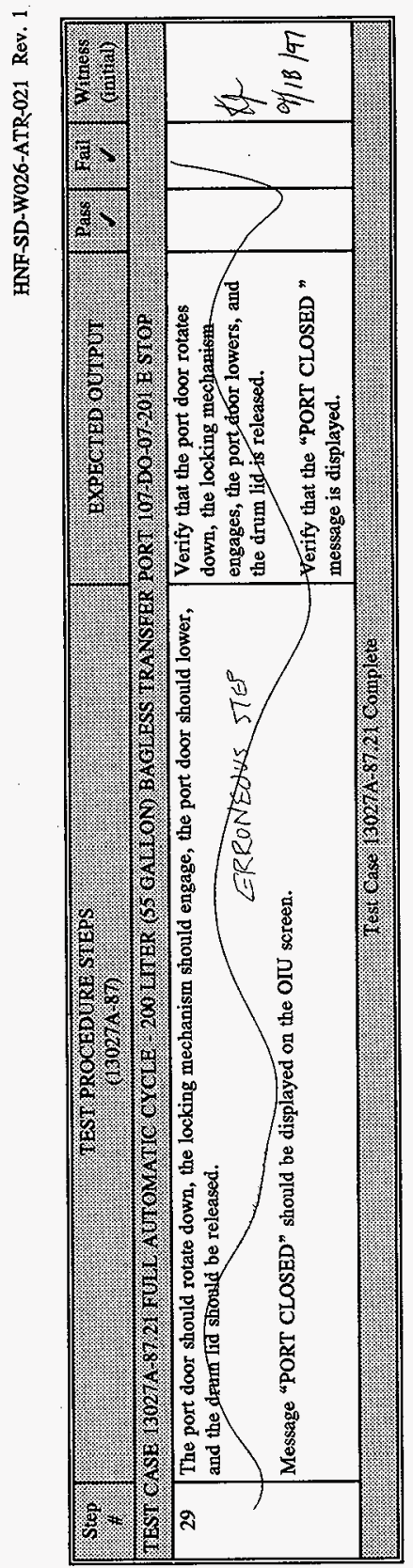

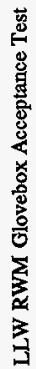


HNF-SD-W026-ATR-021 Rev. 1

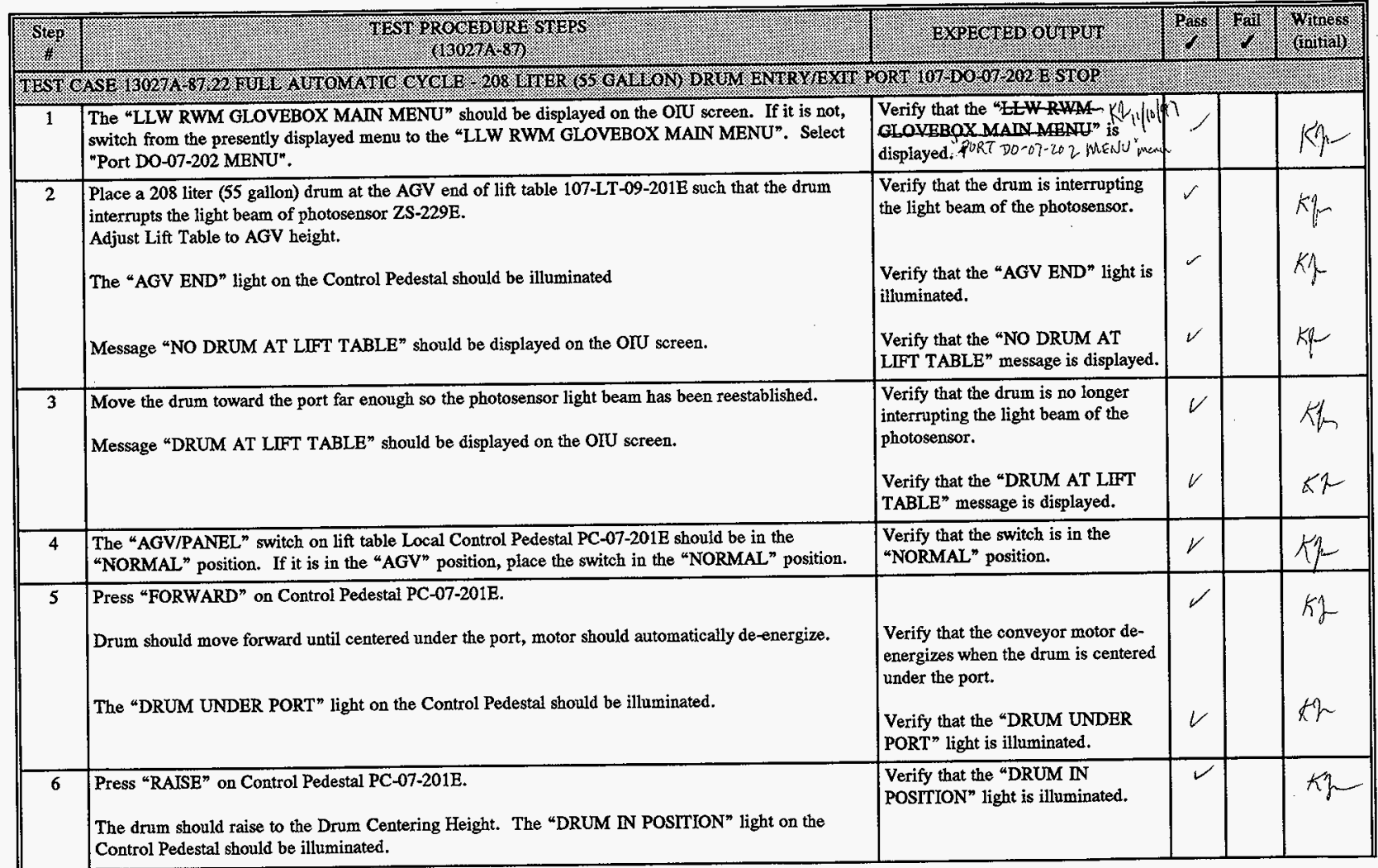


HNF-SD-W026-ATR-021 Rev. 1

\begin{tabular}{|c|c|c|c|c|c|}
\hline Stro & TEST RROGEDURF STGPS: & 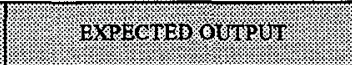 & Yasos & Fin. & (initivil \\
\hline \multicolumn{6}{|c|}{ 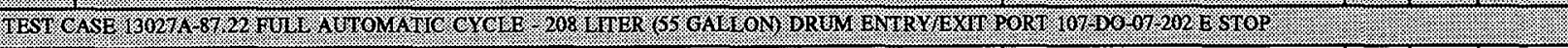 } \\
\hline 7 & $\begin{array}{l}\text { NOTE: When this step is initiated, a series of steps will be performed automatically. } \\
\text { Press "OPEN PORT" on the "PORT DO-07-202 MENU". } \\
\text { Message "PORT OPENING..." should be displayed on the OIU screen. }\end{array}$ & $\begin{array}{l}\text { Verify that the "PORT } \\
\text { OPENING..." message is displayed. }\end{array}$ & $\checkmark$ & & 绎 \\
\hline 8 & The drum centering clamps should extend to center the drum. & $\begin{array}{l}\text { Verify that the drum centering } \\
\text { clamps extend to center the drum. }\end{array}$ & / & & 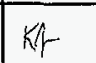 \\
\hline 9 & The vacuum system should be activated by the PCS. & $\begin{array}{l}\text { Verify that the vacuum system is } \\
\text { activated. }\end{array}$ & $\sqrt{1}$ & & $k+$ \\
\hline 10 & The HVAC seal should inflate. & $\begin{array}{l}\text { Verify that the HVAC seal is } \\
\text { inflated. }\end{array}$ & $y$ & & $k_{r}$ \\
\hline 11 & $\begin{array}{l}\text { The PCS should energize vent valves FEV-913C\&D, thereby releasing pressure on the door open/close } \\
\text { cylinders. }\end{array}$ & $\begin{array}{l}\text { Verify that vent valves FEV- } \\
\text { 913C\&D are energized. }\end{array}$ & $\checkmark$ & & $k q$ \\
\hline 12 & The port door locking bolts should both retract. & Verify that both locking boits retract. & $\checkmark$ & & $\overline{k g}$ \\
\hline 13 & The lift table servo motor should raise the drum to the Door in Position height and then stop. & $\begin{array}{l}\text { Verify that the door is raised to the } \\
\text { Door in Position height and then } \\
\text { stops. }\end{array}$ & $\checkmark$ & & kt \\
\hline 14 & $\begin{array}{l}\text { The port door open cylinders should raise the port door to the open position. } \\
\text { The drum lid should remain attached to the port door. }\end{array}$ & $\begin{array}{l}\text { Verify that the port door raises to the } \\
\text { open position. } \\
\text { Verify that the drum lid remains } \\
\text { attached to the port door. }\end{array}$ & $y$ & & \\
\hline 15 & $\begin{array}{l}\text { After the port starts rotating open, place "EMERGENCY STOP" switch 107-HS-201A in the "TRIP" } \\
\text { position. }\end{array}$ & $\begin{array}{l}\text { Verify that the "EMERGENCY } \\
\text { STOP" switch is in the "TRIP" } \\
\text { position. }\end{array}$ & $\checkmark$ & & $k$ \\
\hline 16 & Verify that the port door stops rotating, holds in place, and the lid remains attached to the door & $\begin{array}{l}\text { Verify that the port door stops } \\
\text { rotating, holds in place, and the lid } \\
\text { remains attached to the door. }\end{array}$ & $x$ & $\mathscr{L}$ & 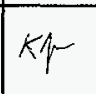 \\
\hline 17 & Reset "EMERGENCY STOP" switch 107-HS-201A. & $\begin{array}{l}\text { Verify "EMERGENCY STOP" } \\
\text { switch is reset. }\end{array}$ & $\psi$ & & \\
\hline
\end{tabular}


HENF-SD-W026-ATR-021 Rev. 1

\begin{tabular}{|c|c|c|c|c|c|}
\hline Step & 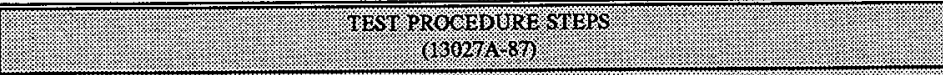 & 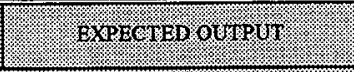 & Pas & 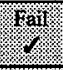 & (initivition \\
\hline \multicolumn{6}{|c|}{ 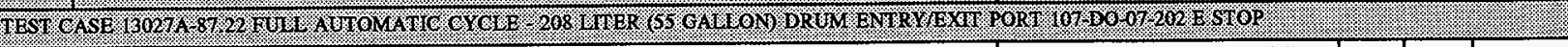 } \\
\hline 18 & $\begin{array}{l}\text { The port door should rotate fully open. } \\
\text { Message "PORT OPEN" should be displayed on the OIU screen. }\end{array}$ & $\begin{array}{l}\text { Verify that the port is rotated fully } \\
\text { open. } \\
\text { Verify that the "PORT OPEN" } \\
\text { message is displayed. }\end{array}$ & $\checkmark$ & & \\
\hline 19 & $\begin{array}{l}\text { NOTE: When this step is initiated, a series of steps will be performed automatically. } \\
\text { Press "CLOSE PORT" on the "PORT DO-07-202 MENU". } \\
\text { Message "PORT CLOSING..." should be displayed on the OrU screen. }\end{array}$ & $\begin{array}{l}\text { Verify that the "PORT } \\
\text { CLOSING..." message is displayed. }\end{array}$ & $v$ & & Ky \\
\hline 20 & $\begin{array}{l}\text { After the port starts rotating closed, place "EMERGENCY STOP" switch 107-HS-201B in the "TRIP" } \\
\text { position. }\end{array}$ & $\begin{array}{l}\text { Verify that the "EMERGENCY } \\
\text { STOP" switch is in the "TRIP" } \\
\text { position. }\end{array}$ & $\mathscr{V}$ & & \\
\hline 21 & Verify that the port door stops rotating, holds in place, and the lid remains attached to the door & $\begin{array}{l}\text { Verify that the port door stops } \\
\text { rotating, holds in place, and the lid } \\
\text { remains attached to the door. }\end{array}$ & $S\left(y^{q+1}\right.$ & $\checkmark$ & \\
\hline 22 & Reset "EMERGENCY STOP" switch 107-HS-201B. & $\begin{array}{l}\text { Verify "EMERGENCY STOP" } \\
\text { switch is reset. }\end{array}$ & 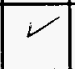 & & $k q$ \\
\hline 23 & The port door should rotate fully closed. & $\begin{array}{l}\text { Verify that the port is rotated fully } \\
\text { closed. }\end{array}$ & 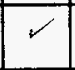 & & $k j$ \\
\hline 24 & The port door open cylinders should lower the port door to the Door in Position height. & $\begin{array}{l}\text { Verify that the port door lowers to } \\
\text { the Door in Position height. }\end{array}$ & $5 / 1 / 97$ & $\checkmark$ & 52 \\
\hline 25 & Vacuum on the drum lid should be released by the PCS. & $\begin{array}{l}\text { Verify that the vacuum is released } \\
\text { from the drum lid. }\end{array}$ & $\checkmark$ & & Kq \\
\hline 26 & The drum lid detachment cylinder should be extended by the PCS. & $\begin{array}{l}\text { Verify that the drum lid detachment } \\
\text { cylinder is extenced. }\end{array}$ & $\checkmark$ & & $k$ \\
\hline 27 & $\begin{array}{l}\text { The lift table should lower to the Drum Centering height by the PCS. } \\
\text { The port door should be fully lowered to the closed position. }\end{array}$ & $\begin{array}{l}\text { Verify that the lift table is lowered to } \\
\text { the Drum Centering height. } \\
\text { Verify that the port door is fully } \\
\text { closed. }\end{array}$ & $\begin{array}{l}\checkmark \\
\checkmark\end{array}$ & & $k i$ \\
\hline
\end{tabular}


HNF-SD-W026-ATR-021 Rev. 1

\begin{tabular}{|c|c|c|c|c|c|}
\hline$\sqrt{5(2)}$ & 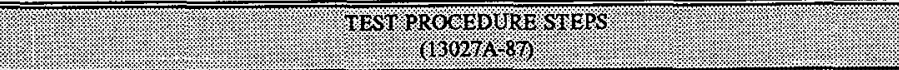 & (1. & (1) & . & Wintins: \\
\hline \multicolumn{6}{|c|}{ 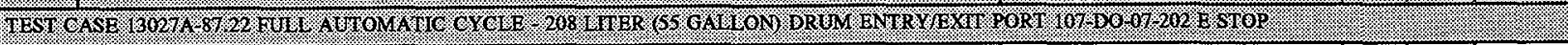 } \\
\hline 28 & The port door locking cylinders should fully extend to lock the port. & $\begin{array}{l}\text { Verify that the port door locking } \\
\text { cylinders are fully extended. }\end{array}$ & $\checkmark$ & & $k q$ \\
\hline 29 & The drum lid detachment cylinder should be retracted by the PCS. & $\begin{array}{l}\text { Verify that the drum lid detachment } \\
\text { cylinder is retracted. }\end{array}$ & $\checkmark$ & & $q$ \\
\hline 30 & $\begin{array}{l}\text { The drum centering clamps should fully retract. } \\
\text { The HVAC seal should fully deflate. } \\
\text { Message "PORT CLOSED" should be displayed on the OIU screen. }\end{array}$ & $\begin{array}{l}\text { Verify that the drum centering } \\
\text { clamps fully retract. } \\
\text { Verify that the HVAC seal is fully } \\
\text { deflated. } \\
\text { Verify that the "PORT CLOSED" } \\
\text { message is displayed. }\end{array}$ & $V$ & & $k f$ \\
\hline 31 & $\begin{array}{l}\text { Press "LOWER" on Control Pedestal PC-07-201E. } \\
\text { The drum should lower to the AGV Height. } \\
\text { The "AGV HEIGHT" light on the Control Pedestal should be illuminated. }\end{array}$ & $\begin{array}{l}\text { Verify that the "AGV HEIGHT" } \\
\text { light is illuminated. }\end{array}$ & 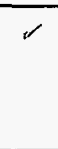 & & \\
\hline 32 & $\begin{array}{l}\text { Press "REVERSE" on Control Pedestal PC-07-201E. } \\
\text { The conveyor should move the drum to the AGV end position. } \\
\text { The "AGV END" light on the Control Pedestal should be illuminated. }\end{array}$ & $\begin{array}{l}\text { Verify that the "AGV END" light is } \\
\text { illuminated. }\end{array}$ & $v$ & & $\begin{array}{l}K \gamma^{\prime} \\
K g\end{array}$ \\
\hline 33 & $\begin{array}{l}\text { Place the "AGV/PANEL" switch on lift table Local Control Pedestal PC-07-201E in the "AGV" } \\
\text { position. }\end{array}$ & $\begin{array}{l}\text { Verify that the switch is in the } \\
\text { "AGV" position. }\end{array}$ & $\checkmark$ & & $\kappa \Re$ \\
\hline & 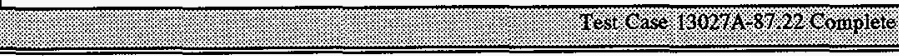 & & & & \\
\hline$i_{33} 110$ & $\begin{array}{l}\text { PAE "DRUM REAPY FOR PICEUP } \\
\text { ORUM PICK WP IN PROGRESS DISPLAYEO ON SCREEN } \\
\text { WOH? }\end{array}$ & & 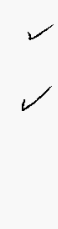 & & $k x$ \\
\hline
\end{tabular}




\begin{tabular}{|c|c|c|c|c|c|}
\hline Sien. & TEST PROCEDURE SUEPS & 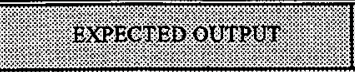 & pras. & trat. & (rinitial) \\
\hline \multicolumn{6}{|c|}{ 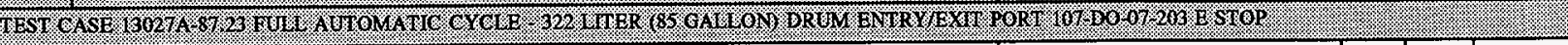 } \\
\hline 1 & $\begin{array}{l}\text { The "LLW RWM GLOVEBOX MAIN MENU" should be displayed on the OIU screen. If it is not, } \\
\text { switch from the presently displayed menu to the "LLW RWM GLOVEBOX MAIN MENU". Select } \\
\text { "Port DO-07-203 MENU". }\end{array}$ & $\begin{array}{l}\text { Verify that the "LLW RWM } \\
\text { GLOVEBOX MAIN MENU" is } \\
\text { displayed. }\end{array}$ & $\checkmark$ & & \\
\hline 2 & $\begin{array}{l}\text { Place a } 322 \text { liter ( } 85 \text { gallon) drum at the AGV end of lift table 107-LT-09-201D such that the drum } \\
\text { interrupts the light beam of photosensor ZS-229E. } \\
\text { The "AGV END" light on the Control Pedestal should be illuminated } \\
\text { Message "NO DRUM AT LIFT TABLE" should be displayed on the OrU screen. }\end{array}$ & $\begin{array}{l}\text { Verify that the drum is interrupting } \\
\text { the light beam of the photosensor. } \\
\text { Verify that the "AGV END" light is } \\
\text { illuminated. } \\
\text { Verify that the "NO DRUM AT } \\
\text { LIFT TABLE" message is displayed. }\end{array}$ & $\checkmark$ & & Kin \\
\hline 3 & $\begin{array}{l}\text { Move the drum toward the port far enough so the photosensor light beam has been reestablished. } \\
\text { Message "DRUM AT LIFT TABLE" should be displayed on the OIU screen. }\end{array}$ & $\begin{array}{l}\text { Verify that the drum is no longer } \\
\text { interrupting the light beam of the } \\
\text { photosensor. } \\
\text { Verify that the "DRUM AT LIFT } \\
\text { TABLE" message is displayed. }\end{array}$ & $\checkmark$ & & $k$ \\
\hline 4 & $\begin{array}{l}\text { The "AGV/PANEL" switch on lift table Local Control Pedestal PC-07-201D should be in the } \\
\text { "NORMAL" position. If it is in the "AGV" position, place the switch in the "NORMAL" position. }\end{array}$ & $\begin{array}{l}\text { Verify that the switch is in the } \\
\text { "NORMAL" position. }\end{array}$ & $\checkmark$ & & $K g^{2}$ \\
\hline 5 & $\begin{array}{l}\text { Press "LOWER" on Control Pedestal PC-07-201D. } \\
\text { The lift table should lower to a preprogrammed position of } 18^{\prime \prime} \pm 1 / 8^{n} \text { above the floor. }\end{array}$ & $\begin{array}{l}\text { Verify that the lift table lowers to the } \\
\text { preprogrammed position. }\end{array}$ & $\nearrow$ & & $k r$ \\
\hline 6 & $\begin{array}{l}\text { Press "FORWARD" on Control Pedestal PC-07-201D. } \\
\text { Drum should move forward until centered under the port, motor should automatically de-energize. } \\
\text { The "DRUM UNDER PORT" light on the Control Pedestal should be illuminated. }\end{array}$ & $\begin{array}{l}\text { Verify that the conveyor motor de- } \\
\text { energizes when the drum is centered } \\
\text { under the port. } \\
\text { Verify that the "DRUM UNDER } \\
\text { PORT" light is illuminated. }\end{array}$ & 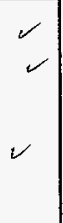 & & $k+$ \\
\hline
\end{tabular}


HNF-SD-W026-ATR-021 Rev. 1

\begin{tabular}{|c|c|c|c|c|c|}
\hline Step & TEST PROCEOURT ST EPS & 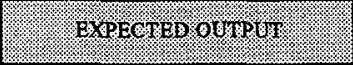 & Pas & Iari: & Winess \\
\hline \multicolumn{6}{|c|}{ 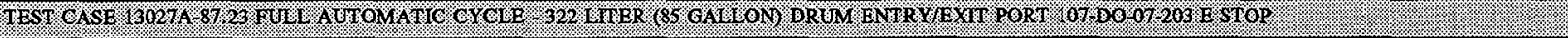 } \\
\hline 7 & $\begin{array}{l}\text { Press "RAISE" on Control Pedestal PC-07-201D. } \\
\text { The drum should raise to the Drum Centering Height. The "DRUM IN POSITION" light on the } \\
\text { Control Pedestal should be illuminated. }\end{array}$ & $\begin{array}{l}\text { Verify that the "DRUM NN } \\
\text { PosITION" light is illuminated. }\end{array}$ & $\mathscr{V}$ & & \\
\hline 8 & $\begin{array}{l}\text { Press "PORT DO-07-203 MENU" on the "LLW RWM GLOVEBOX MANN MENU". } \\
\text { The "PORT DO-07-203 MENU" should be displayed. }\end{array}$ & $\begin{array}{l}\text { Verify that the "PORT D0-07-203 } \\
\text { MENU" is displayed. }\end{array}$ & $\checkmark$ & & \\
\hline 9 & $\begin{array}{l}\text { NOTE: When this step is initiated, a series of steps will be performed automatically. } \\
\text { Press "OPEN PORT" on the "PORT DO-07-203 MENU". } \\
\text { Message "PORT OPENING..." should be displayed on the OIU screen. "Z }\end{array}$ & $\begin{array}{l}\text { Verify that the "PORT } \\
\text { OPENING..." message is displayed. }\end{array}$ & X & 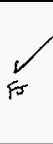 & \\
\hline 10 & The drum centering clamps should extend to center the drum. & $\begin{array}{l}\text { Verify that the drum centering } \\
\text { clamps extend to center the drum. }\end{array}$ & & & $\not$ \\
\hline 11 & The vacuum system should be activated by the PCS. & $\begin{array}{l}\text { Verify that the vacuum system is } \\
\text { activated. }\end{array}$ & v & & \\
\hline 12 & The HVAC seal should inflate. & $\begin{array}{l}\text { Verify that the HVAC seal is } \\
\text { inflated. }\end{array}$ & $\checkmark$ & & $k$ \\
\hline 13 & $\begin{array}{l}\text { The PCS should energize vent valves FEV-913A\&B, thereby releasing pressure on the door open/close } \\
\text { cylinders. }\end{array}$ & $\begin{array}{l}\text { Verify that vent valves FEV- } \\
913 \mathrm{~A} \& \mathrm{~B} \text { are energized. }\end{array}$ & 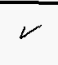 & & \\
\hline 14 & The port door locking bolts should both retract. & Verify that both locking bolts retract. & 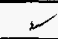 & & 52 \\
\hline 15 & The lift table servo motor should raise the drum to the Door in Position height and then stop. & $\begin{array}{l}\text { Verify that the door is raised to the } \\
\text { Door in Position height and then } \\
\text { stops. }\end{array}$ & L & & \\
\hline 16 & $\begin{array}{l}\text { The port door open cylinders should raise the port door to the open position. } \\
\text { The drum lid should remain attached to the port door. }\end{array}$ & $\begin{array}{l}\text { Verify that the port door raises to the } \\
\text { open position. } \\
\text { Verify that the drum lid remains } \\
\text { attached to the port door. }\end{array}$ & $V$ & & \\
\hline 17 & $\begin{array}{l}\text { After the port starts rotating open, place "EMERGENCY STOP" switch 107-HS-201A in the "TRIP" } \\
\text { position. }\end{array}$ & $\begin{array}{l}\text { Verify that the "EMERGENCY } \\
\text { STOP" switch is in the "TRIP" } \\
\text { position. }\end{array}$ & $\checkmark$ & & $k 2$ \\
\hline
\end{tabular}


HNF-SD-W026-ATR-021 Rev. 1

\begin{tabular}{|c|c|c|c|c|c|}
\hline Sten & 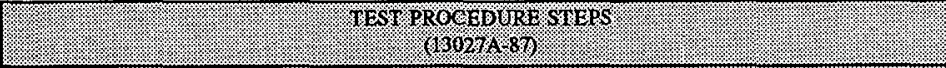 & 3. & Pas. & (8) & (rivitivil. \\
\hline \multicolumn{6}{|c|}{ 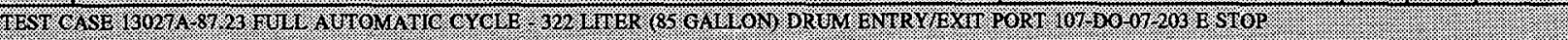 } \\
\hline 18 & Verify that the port door stops rotating, holds in place, and the lid remains attached to the door & $\begin{array}{l}\text { Verify that the port door stops } \\
\text { rotating, holds in place, and the lid } \\
\text { remains attached to the door. }\end{array}$ & l & & gr \\
\hline 19 & Reset "EMERGENCY STOP" switch 107-HS-201A. & $\begin{array}{l}\text { Verify "EMERGENCY STOP" } \\
\text { switch is reset. }\end{array}$ & V & & $k$ \\
\hline 20 & $\begin{array}{l}\text { The port door should rotate fully open. } \\
\text { Message "PORT OPEN" should be displayed on the OIU screen. }\end{array}$ & $\begin{array}{l}\text { Verify that the port is rotated fully } \\
\text { open. } \\
\text { Verify that the "PORT OPEN" } \\
\text { message is displayed. }\end{array}$ & $\checkmark$ & & $K k$ \\
\hline 21 & $\begin{array}{l}\text { NOTE: When this step is initiated, a series of steps will be performed automatically. } \\
\text { Press "CLOSE PORT" on the "PORT DO-07-203 MENU". } \\
\text { Message "PORT CLOSING..." should be displayed on the OIU screen. }\end{array}$ & $\begin{array}{l}\text { Verify that the "PORT } \\
\text { CLOSING..." message is displayed. }\end{array}$ & $V$ & & +2 \\
\hline 22 & $\begin{array}{l}\text { After the port starts rotating closed, place "EMERGENCY STOP" switch 107-HS-201B in the "TRIP" } \\
\text { position. }\end{array}$ & $\begin{array}{l}\text { Verify that the "EMERGENCY } \\
\text { STOP" switch is in the "TRIP" } \\
\text { position. }\end{array}$ & $\mathcal{L}$ & & 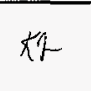 \\
\hline 23 & Verify that the port door stops rotating, holds in place, and the lid remains attached to the door & $\begin{array}{l}\text { Verify that the port door stops } \\
\text { rotating, holds in place, and the lid } \\
\text { remains attached to the door. }\end{array}$ & $\checkmark$ & & $x^{3}$ \\
\hline 24 & Reset "EMERGENCY STOP" switch 107-HS-201B. & $\begin{array}{l}\text { Verify "EMERGENCY STOP" } \\
\text { switch is reset. }\end{array}$ & $\checkmark$ & & $k$ \\
\hline 25 & The port door should rotate fully closed. & $\begin{array}{l}\text { Verify that the port is rotated fully } \\
\text { closed. }\end{array}$ & $u$ & & $\pi \nu$ \\
\hline 26 & The port door open cylinders should lower the port door to the Door in Position height. & $\begin{array}{l}\text { Verify that the port door lowers to } \\
\text { the Door in Position height. }\end{array}$ & L & & $\mathrm{Kl}$ \\
\hline 27 & Vacuum on the drum lid should be released by the PCS. & $\begin{array}{l}\text { Verify that the vacuum is released } \\
\text { from the drum lid. }\end{array}$ & $V$ & & Ky \\
\hline 28 & The drum lid detachment cylinder should be extended by the PCS. & $\begin{array}{l}\text { Verify that the drum lid detachment } \\
\text { cylinder is extended. }\end{array}$ & $\checkmark$ & & $\pi j$ \\
\hline
\end{tabular}


HNF-SD-W026-ATR-021 Rev. 1

\begin{tabular}{|c|c|c|c|c|c|}
\hline Step & 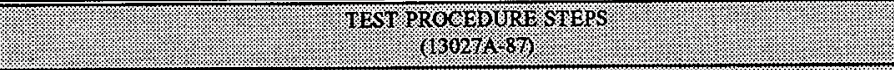 & EXPECTEP OUTPUT & (2) & (8) & (rivitivi) \\
\hline \multicolumn{6}{|c|}{ 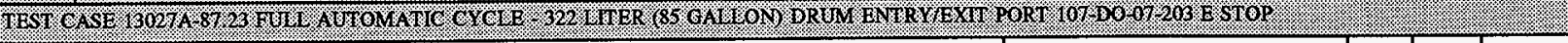 } \\
\hline 29 & $\begin{array}{l}\text { The lift table should lower to the Drum Centering height by the PCS. } \\
\text { The port door should be fully lowered to the closed position. }\end{array}$ & $\begin{array}{l}\text { Verify that the lift table is lowered to } \\
\text { the Drum Centering height. } \\
\text { Verify that the port door is fully } \\
\text { closed. }\end{array}$ & $V$ & & $\$$ \\
\hline 30 & The port door locking cylinders should fully extend to lock the port. & $\begin{array}{l}\text { Verify that the port door locking } \\
\text { cylinders are fully extended. }\end{array}$ & $\checkmark$ & & $k+2$ \\
\hline 31 & The drum lid detachment cylinder should be retracted by the PCS. & $\begin{array}{l}\text { Verify that the drum lid detachment } \\
\text { cylinder is retracted. }\end{array}$ & $V$ & & $k \gamma$ \\
\hline 32 & $\begin{array}{l}\text { The drum centering clamps should fully retract. } \\
\text { The HVAC seal should fully deflate. } \\
\text { Message "PORT CLOSED" should be displayed on the OIU screen. }\end{array}$ & $\begin{array}{l}\text { Verify that the drum centering } \\
\text { clamps fully retract. } \\
\text { Verify that the HVAC seal is fully } \\
\text { deflated. } \\
\text { Verify that the "PORT CLOSED" } \\
\text { message is displayed. }\end{array}$ & $v$ & & $\begin{array}{l}k \gamma \\
k r- \\
k z\end{array}$ \\
\hline 33 & $\begin{array}{l}\text { Press "LOWER" on Control Pedestal PC-07-201D. } \\
\text { The drum should lower to the preprogrammed position. }\end{array}$ & $\begin{array}{l}\text { Verify that the lift table lowers to the } \\
\text { preprogrammed position. }\end{array}$ & $\checkmark$ & & $\pi 2$ \\
\hline 34 & $\begin{array}{l}\text { Press "REVERSE" on Control Pedestal PC-07-201D. } \\
\text { The conveyor should move the drum to the AGV end position. } \\
\text { The "AGV END" light on the Control Pedestal should be illuminated. }\end{array}$ & $\begin{array}{l}\text { Verify that the "AGV END" light is } \\
\text { illuminated. }\end{array}$ & $V$ & & $x y$ \\
\hline 35 & $\begin{array}{l}\text { Press "RAISE" on Control Pedestal PC-07-201D. } \\
\text { The lift table should raise to the AGV height. } \\
\text { The "AGV HEIGHT" light on the Control Pedestal should be illuminated. }\end{array}$ & $\begin{array}{l}\text { Verify that the "AGV HEIGHT" } \\
\text { light is illuminated. }\end{array}$ & $r$ & & $k^{2}$ \\
\hline 36 & $\begin{array}{l}\text { Place the "AGV/PANEL" switch on lift table Local Control Pedestal PC-07-201D in the "AGV" } \\
\text { position. }\end{array}$ & $\begin{array}{l}\text { Verify that the switch is in the } \\
\text { "AGV" position. }\end{array}$ & $\checkmark$ & & $k g$ \\
\hline & 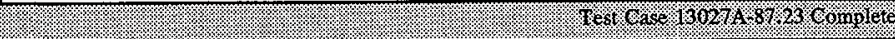 & & & & \\
\hline
\end{tabular}


HNF-SD-W026-ATR-021 Rev. 1

\begin{tabular}{|c|c|c|c|c|c|}
\hline Step & TEST PROCEDURP STINPS: & 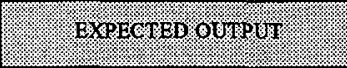 & I.: & (6) & (rintivilu \\
\hline \multicolumn{6}{|c|}{ 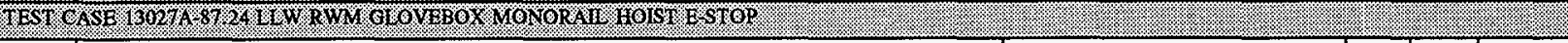 } \\
\hline 1 & $\begin{array}{l}\text { Place the Glovebox Monorail Hoist pendant 107-PC-07-009A "Pendant Select" switch to the "PEND } \\
\text { A" position. } \\
\text { The enabled indicator on "PEND A" should be illuminated. }\end{array}$ & $\begin{array}{l}\text { Verify that the 107-PC-07-009A } \\
\text { hoist pendant "Pendant Select" } \\
\text { switch is placed in the "PEND A" } \\
\text { position. } \\
\text { Verify that the "ENABLED" } \\
\text { indicator is illuminated. }\end{array}$ & $f$ & & \\
\hline 2 & $\begin{array}{l}\text { Confirm that the LLW RWM Glovebox Monorail Hoist (107-CR-07-201) is unloaded (no transfer } \\
\text { stand attached) and fully raised. If necessary, unload the hoist and use the hoist/trolley pendant (107- } \\
\text { PC-07-009A) to fully raise the hoist. } \\
\text { The hoist "RAISED LIMIT" indicator should be illuminated, indicating that the hoist is fully raised. }\end{array}$ & $\begin{array}{l}\text { Visually verify that the hoist is } \\
\text { unloaded (no transfer stand attached) } \\
\text { and fully raised. } \\
\text { Verify that hoist "RAISED LIMIT" } \\
\text { indicator is illuminated. }\end{array}$ & $\checkmark$ & & \\
\hline 3 & $\begin{array}{l}\text { Activate the Trolley/Hoist Pendant (105-PC-07-009A) Right pushbutton to energize trolley motor 107- } \\
\text { CR-07-201/M1 so that the troiley moves towards Port } 202 \text {. }\end{array}$ & $\begin{array}{l}\text { Verify that Trolley/Hoist Pendant } \\
\text { Right pushbutton is energized. }\end{array}$ & $\checkmark$ & & \\
\hline 4 & $\begin{array}{l}\text { After the trolley starts moving, place "EMERGENCY STOP" switch 107-HS-201A IN THE "TRIP" } \\
\text { position. }\end{array}$ & $\begin{array}{l}\text { Verify that the "EMERGENCY } \\
\text { STOP" switch is in the "TRIP" } \\
\text { position }\end{array}$ & $\omega$ & & \\
\hline 5 & Verify that the Trolley $107-$ CR-07-201 stops moving. & $\begin{array}{l}\text { Trolley 107-CR-07-201 stops } \\
\text { moving. }\end{array}$ & 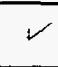 & & \\
\hline$\overline{6}$ & $\begin{array}{l}\text { Attempt to move Trolley 107-CR-07-201 Left/Right by depressing the "LEFT/RIGHT" pushbuttons on } \\
\text { 107-PC-07-009AC. }\end{array}$ & $\begin{array}{l}\text { Verify that Trolley 107-CR-07-201 } \\
\text { does not move. }\end{array}$ & $\sim$ & & \\
\hline 7 & Attempt to Lower/Raise Hoist 107-CR-07-201 by depressing "LOWER/RAISE" on 107-PC-07-009A. & $\begin{array}{l}\text { Verify that Hoist 107-CR-07-201 } \\
\text { does not lower or raise. }\end{array}$ & $v$ & & \\
\hline 8 & Reset "EMERGENCY STOP" switch 107-HS-201A. & $\begin{array}{l}\text { Verify that "EMERGENCY STOP" } \\
\text { switch 107-HS-201A is reset. }\end{array}$ & $\checkmark$ & & \\
\hline 9 & $\begin{array}{l}\text { Place Glovebox Monorail Hoist Pendant 107-PC-07-009A "PENDANT SELECT" select switch to the } \\
\text { "PEND B" position. }\end{array}$ & $\begin{array}{l}\text { Verify that the Glovebox Monorail } \\
\text { Hoist Pendant 107-PC-07-009A } \\
\text { "PENDANT SELECT" switch is set } \\
\text { to "PEND B" position. }\end{array}$ & $\smile$ & & \\
\hline
\end{tabular}


HNF-SD-W026-ATP-021 Rev. 1

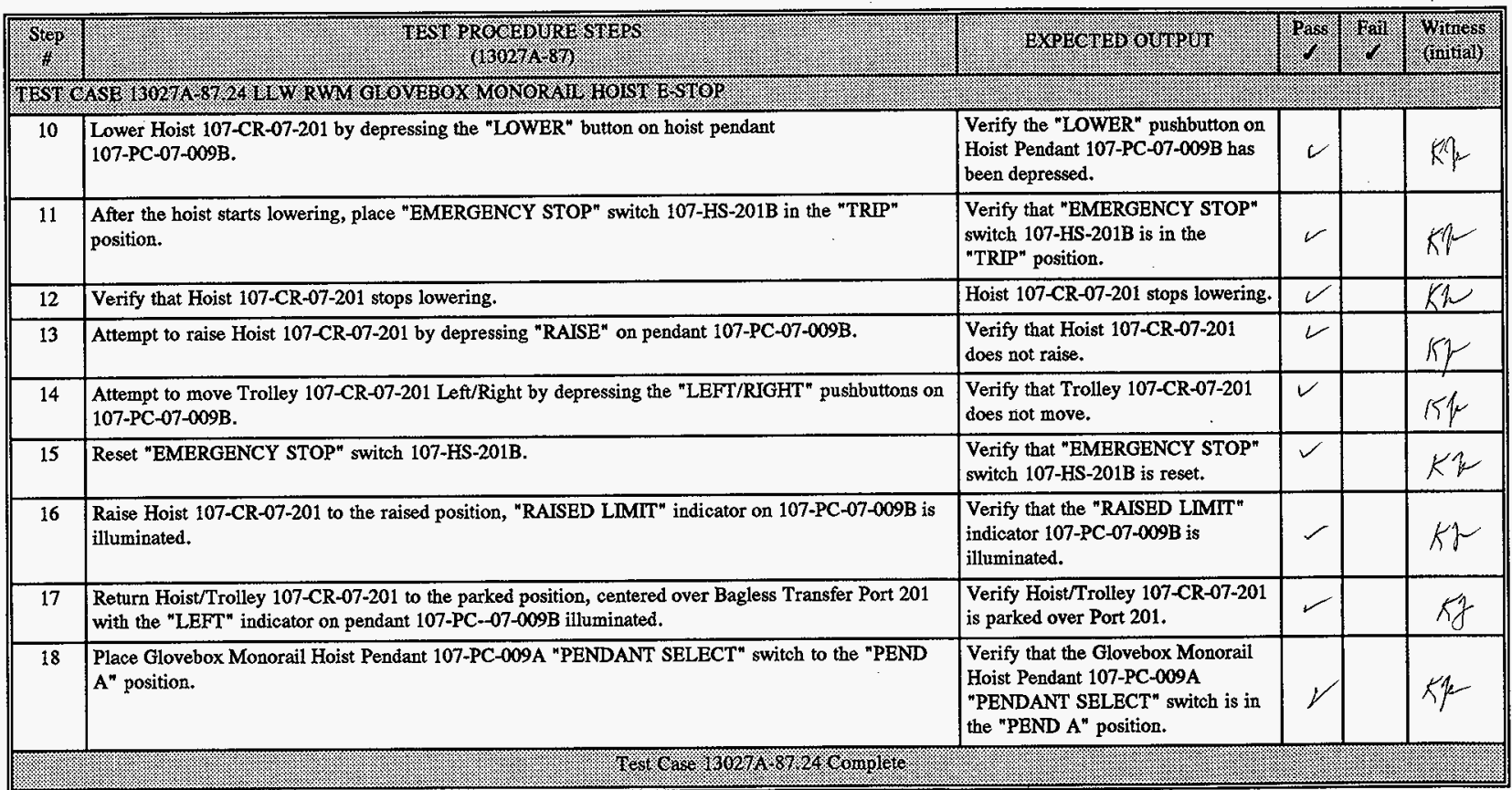


HNF-SD-W026-ATR-021 Rev. 1

\begin{tabular}{|c|c|c|c|c|c|}
\hline 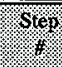 & TEST PRGOEDURE STEPS & 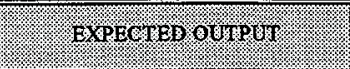 & Paso: & 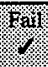 & ronitialy \\
\hline \multicolumn{6}{|c|}{ 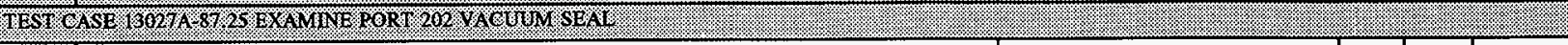 } \\
\hline 1 & Install 0-30" Hg Vacuum Gauge on PORT 202 Vacuum sensing line. & $\begin{array}{l}\text { Verify that } 0-30^{+} \text {Vacuum Gauge is } \\
\text { installed. }\end{array}$ & $\checkmark$ & & Kl \\
\hline 2 & $\begin{array}{l}\text { Place a } 208 \text { liter (55 gallon) drum with weighted lid at the AGV end of Lift Table } \\
\text { 107-LT-09-201E. }\end{array}$ & $\begin{array}{l}\text { Verify that the drum is positioned on } \\
\text { the lift table at the AGV end. }\end{array}$ & $V$ & & \\
\hline 3 & Mate the 55 gallon drum with weighted lid to Port 202 . & Verify that the drum is at Port 202. & 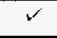 & & 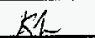 \\
\hline 4 & $\begin{array}{l}\text { Press "PORT DO-07-202 MAINTENANCE MENU" on the "MAINTENANCE MAIN MENU". } \\
\text { The "PORT DO-07-202 MAINTENANCE MENU" should be displayed. }\end{array}$ & $\begin{array}{l}\text { Verify that "PORT DO-07-202 } \\
\text { MAINTENANCE MENU" is } \\
\text { selected. } \\
\text { Verify that the "PORT DO-07-202 } \\
\text { MAINTENANCE MENU" is } \\
\text { displayed. }\end{array}$ & 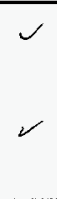 & & KI \\
\hline 5 & $\begin{array}{l}\text { Press "OPEN TSOLATIONVALVE" on the "PORT DO-07-202 MAINTENANCE MENU" } \\
\text { Vacuum OFF. K/ } 11 / 10 / 9 \text { ? }\end{array}$ & $\begin{array}{l}\text { Verify that the vacuum supply valve } \\
\text { is open. }\end{array}$ & $\checkmark$ & & Kl \\
\hline 6 & 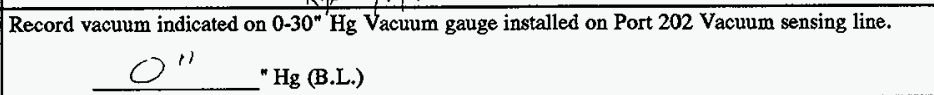 & $\begin{array}{l}\text { Verify that indicated vacuum is } \\
\text { recorded. }\end{array}$ & $r$ & & $\pi f$ \\
\hline 7 & Verify Port 202 Vacuum System is not on. & $\begin{array}{l}\text { Verify vacuum not present on Port } \\
202 .\end{array}$ & $\nu$ & & $k \mathcal{k}$ \\
\hline 8 & Press "TURN ON VACUUM" on the "PORT DO-07-202 MAINTENANCE MENU". & $\begin{array}{l}\text { Verify that the vacuum supply } \\
\text { system is on. }\end{array}$ & $V$ & & $r ?$ \\
\hline 9 & $\begin{array}{l}\text { Record vacuum indicated on } 0-30^{\prime \prime} \mathrm{Hg} \text { Vacuum gauge installed on Port } 202 \text { Vacuum sensing line and } \\
\text { verify the value is greater that } 14^{\prime \prime} \mathrm{Hg} \text {. } \\
\qquad 18.2\end{array}$ & $\begin{array}{l}\text { Verify that the indicated vacuum is } \\
\text { greater than } 14^{\prime \prime} \mathrm{Hg} \text { and is recorded. }\end{array}$ & $\checkmark$ & & \\
\hline 10 & Press "UNLOCK PORT" on the "PORT D0-07-202 MAINTENANCE MENU". & $\begin{array}{l}\text { Verify that both shot bolts are fully } \\
\text { retracted. }\end{array}$ & r & & $K F$ \\
\hline 11 & Press "RAISE DOOR" on the "PORT DO-07-202 MAINTENANCE MENU". & Verify that the Port Door is open. & 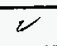 & & $k \eta$ \\
\hline 12 & Verify that the Port 202 port door is open and that the weighted lid is attached to the port door. & $\begin{array}{l}\text { Verify that the weighted lid is } \\
\text { attached to the port door. }\end{array}$ & $\nu$ & & $k \%$ \\
\hline
\end{tabular}


HNF-SD-W026-ATR-021 Rev. 1

\begin{tabular}{|c|c|c|c|c|c|}
\hline Step & 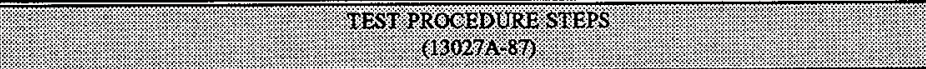 & 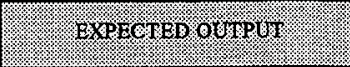 & 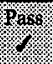 & thats. & (Wining) \\
\hline \multicolumn{6}{|c|}{ 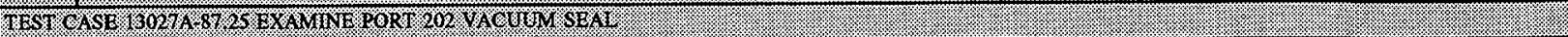 } \\
\hline 13 & $\begin{array}{l}\text { Record vacuum indicated on } 0-30^{\prime \prime} \mathrm{Hg} \text { Vacuum gauge installed on Port } 202 \text { Vacuum sensing line and } \\
\text { verify the value is greater that } 14^{\prime \prime} \mathrm{Hg} \text {. } \\
13.2\end{array}$ & $\begin{array}{l}\text { Verify that the indicated vacuum is } \\
\text { greater than } 14^{\prime \prime} \mathrm{Hg} \text { and is recorded. }\end{array}$ & $\checkmark$ & & K? \\
\hline 14 & Press "LOWER DOOR" on the "PORT DO-07-202 MAINTENANCE MENU". & Verify that the Port Door is closed. & $\checkmark$ & & $K \lambda$ \\
\hline 15 & Press "TURN OFF VACUUM" on the "PORT DO-07-202 MAINTENANCE MENU". & $\begin{array}{l}\text { Verify that the vacuum supply } \\
\text { system is off. }\end{array}$ & I & & 2 \\
\hline 16 & $\begin{array}{l}\text { Press "OREN-ISOLATION-VALVE" on the "PORT DO-07-202 MAINTENANCE MENU" } \\
\text { E-RRONEOUS STEP K/ } 11 / 10 / 97\end{array}$ & $\begin{array}{l}\text { Verify that the vacuum supply valve } \\
\text { is open. }\end{array}$ & $V$ & & \\
\hline 17 & $\begin{array}{l}\text { Record vacuum indicated on } 0-30^{\prime \prime} \mathrm{Hg} \text { Vacuum gauge installed on Port } 202 \text { Vacuum sensing line and } \\
\text { verify the value is greater that } 14^{\prime \prime} \mathrm{Hg} \text {. }\end{array}$ & $\begin{array}{l}\text { Verify that the indicated vacuum is } \\
\text { less than } 2^{n} \mathrm{Hg} \text { and is recorded. }\end{array}$ & $V$ & & \\
\hline 18 & Press "EXTEND LID DETACH" on the "PORT DO-07-202 MAINTENANCE MENU" & $\begin{array}{l}\text { Verify that the lid detach cylinder } \\
\text { fully extends. }\end{array}$ & $\checkmark$ & & $k 2$ \\
\hline 19 & Verify the lid is detached from Port 202 port door. & $\begin{array}{l}\text { Lid is detached from Port } 202 \text { port } \\
\text { door. }\end{array}$ & $\checkmark$ & & $k 2$ \\
\hline 20 & Press "RETRACT LID DETACH" on the "PORT DO-07-202 MAINTENANCE MENU" & $\begin{array}{l}\text { Verify that the lid detach cylinder } \\
\text { fully retracts. }\end{array}$ & 1 & & 52 \\
\hline 21 & Press "LOCK PORT" on the "PORT DO-07-202 MAINTENANCE MENU". & $\begin{array}{l}\text { Verify that both shot boits are fully } \\
\text { extended. }\end{array}$ & $V$ & & $r$ \\
\hline 22 & Remove the 55 gallon drum from Port 202. & & 2 & & $k 2$ \\
\hline 23 & Remove the 0-30" Hg Vacuum Gauge installed on the Port 202 Vacuum sensing line. & $\begin{array}{l}\text { Verify that 0-30" } \mathrm{Hg} \text { Vacuum Gauge } \\
\text { is removed. }\end{array}$ & 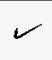 & & $k 2$ \\
\hline
\end{tabular}


HNF-SD-W026-ATR-021 Rev. 1

\begin{tabular}{|c|c|c|c|c|c|}
\hline Ster. & 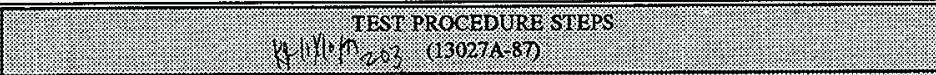 & 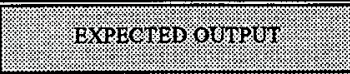 & Pass. & (8) & Witinoss: \\
\hline \multicolumn{6}{|c|}{ 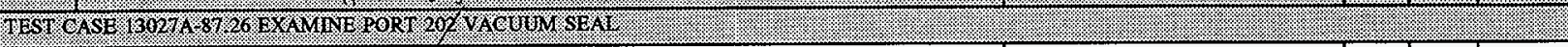 } \\
\hline 1 & Install 0-30" Hg Vacuum Gauge on PORT 203 Vacuum sensing line. & $\begin{array}{l}\text { Verify that 0-30" Vacuum Gauge is } \\
\text { installed. }\end{array}$ & $\checkmark$ & & kn \\
\hline 2 & $\begin{array}{l}\text { Place a } 322 \text { liter ( } 85 \text { galion) drum with weighted lid at the AGV end of Lift Table } \\
\text { 107-LT-09-201E. }\end{array}$ & $\begin{array}{l}\text { Verify that the drum is positioned on } \\
\text { the lift table at the } A G V \text { end. }\end{array}$ & $v$ & & \\
\hline 3 & Mate the 85 gallon drum with weighted lid to Port 203. & Verify that the drum is at Port 203. & L & & Kq \\
\hline 4 & $\begin{array}{l}\text { Press "PORT DO-07-203 MAINTENANCE MENU" on the "MAINTENANCE MAIN MENU". } \\
\text { The "PORT DO-07-203 MAINTENANCE MENU" should be displayed. }\end{array}$ & $\begin{array}{l}\text { Verify that "PORT DO-07-203 } \\
\text { MAINTENANCE MENU" is } \\
\text { selected. } \\
\text { Verify that the "PORT DO-07-203 } \\
\text { MAINTENANCE MENU" is } \\
\text { displayed. }\end{array}$ & $V$ & & $k r$ \\
\hline 5 & 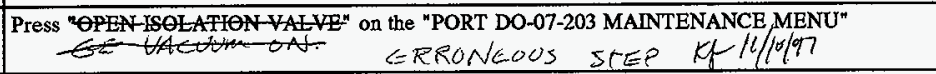 & $\begin{array}{l}\text { Verify that the vacuum suppiy valve } \\
\text { is open. }\end{array}$ & $\bar{\nu}$ & & $k 2$ \\
\hline 6 & 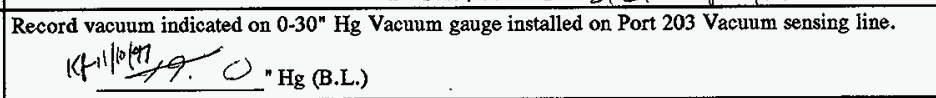 & $\begin{array}{l}\text { Verify that indicated vacuum is } \\
\text { recorded. }\end{array}$ & $\checkmark$ & & \\
\hline 7 & Verify Port 203 Vacuum System is not on. & $\begin{array}{l}\text { Verify vacuum not present on Port } \\
203\end{array}$ & $V$ & & +2 \\
\hline 8 & Press "TURN ON VACUUM" on the "PORT DO-07-203 MAINTENANCE MENU". & $\begin{array}{l}\text { Verify that the vacuum supply } \\
\text { system is on. }\end{array}$ & $\checkmark$ & & $K F$ \\
\hline 9 & $\begin{array}{l}\text { Record vacuum indicated on } 0-30^{\prime \prime} \mathrm{Hg} \text { Vacuum gauge installed on Port } 203 \text { Vacuum sensing line and } \\
\text { verify the value is greater that } 14^{n} \mathrm{Hg} \text {. } \\
\end{array}$ & $\begin{array}{l}\text { Verify that the indicated vacuum is } \\
\text { greater than } 14^{\prime \prime} \mathrm{Hg} \text { and is recorded. }\end{array}$ & $\nearrow$ & & \\
\hline 10 & Press "UNLOCK PORT" on the "PORT D0-07-203 MAINTENANCE MENU". & $\begin{array}{l}\text { Verify that both shot bolts are fully } \\
\text { retracted. }\end{array}$ & $\nu$ & & 72 \\
\hline 11 & Press "RAISE DOOR" on the "PORT DO-07-203 MAINTENANCE MENU". & Verify that the Port Door is open. & 2 & & $K 2$ \\
\hline 12 & Verify that the Port 203 port door is open and that the weighted lid is attached to the port door. & $\begin{array}{l}\text { Verify that the weighted lid is } \\
\text { attached to the port door. }\end{array}$ & 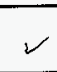 & & $K K$ \\
\hline
\end{tabular}


HNF-SD-W026-ATR-021 Rev. 1

\begin{tabular}{|c|c|c|c|c|c|}
\hline Step. & 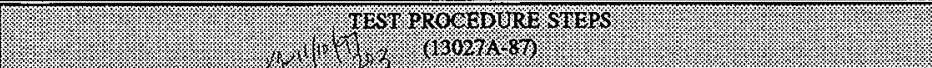 & 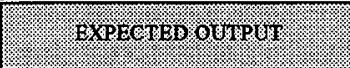 & 19as, & f. & 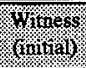 \\
\hline \multicolumn{6}{|c|}{ 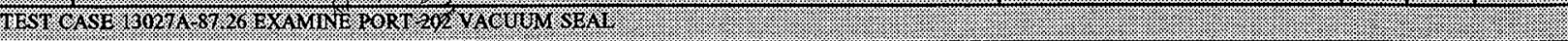 } \\
\hline \multirow[t]{2}{*}{13} & $\begin{array}{l}\text { Record vacuum indicated on } 0-30^{\prime \prime} \mathrm{Hg} \text { Vacuum gauge installed on Port } 203 \text { Vacuum sensing line and } \\
\text { verify the value is greater that } 14^{\prime \prime} \mathrm{Hg} \text {. }\end{array}$ & \multirow[t]{2}{*}{$\begin{array}{l}\text { Verify that the indicated vacuum is } \\
\text { greater than } 14^{*} \mathrm{Hg} \text { and is recorded. }\end{array}$} & \multirow{2}{*}{$\checkmark$} & & \multirow{2}{*}{$k t$} \\
\hline & $19.2 . " \mathrm{Hg}\left(>14^{\prime \prime} \mathrm{Hg}\right)$ & & & & \\
\hline 14 & Press "LOWER DOOR" on the "PORT DO-07-203 MAINTENANCE MENU". & Verify that the Port Door is closed. & 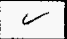 & & $k 2$ \\
\hline 15 & Press "TURN OFF VACUUM" on the "PORT DO-07-203 MAINTENANCE MENU". & $\begin{array}{l}\text { Verify that the vacuum supply } \\
\text { system is off. }\end{array}$ & $r$ & & \\
\hline 16 & 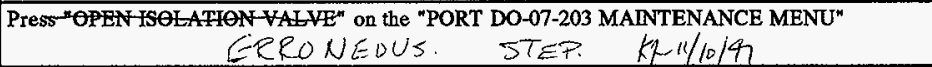 & $\begin{array}{l}\text { Verify that the vacuum supply valve } \\
\text { is open. }\end{array}$ & 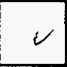 & & $K 2$ \\
\hline 17 & 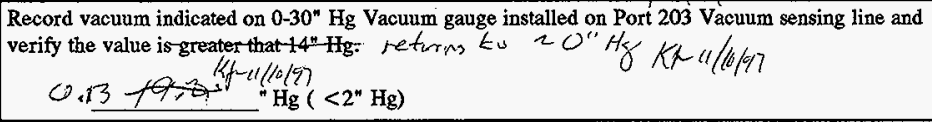 & $\begin{array}{l}\text { Verify that the indicated vacuum is } \\
\text { less than } 2^{\prime \prime} \mathrm{Hg} \text { and is recorded. }\end{array}$ & $\$ 1197$ & & \\
\hline 18 & Press "EXTEND LDD DETACH" on the "PORT DO-07-203 MAINTENANCE MENU" & $\begin{array}{l}\text { Verify that the lid detach cylinder } \\
\text { fully extends. }\end{array}$ & $\checkmark$ & & Kt \\
\hline 19 & Verify the lid is detached from Port 203 port door. & $\begin{array}{l}\text { Lid is detached from Port } 203 \text { port } \\
\text { door. }\end{array}$ & (1) & & $k /$ \\
\hline 20 & Press "RETRACT LID DETACH" on the "PORT DO-07-203 MAINTENANCE MENU" & $\begin{array}{l}\text { Verify that the lid detach cylinder } \\
\text { fully retracts. }\end{array}$ & $\checkmark$ & & Ky \\
\hline 21 & Press "LOCK PORT" on the "PORT DO-07-203 MAINTENANCE MENU". & $\begin{array}{l}\text { Verify that both shot boits are fully } \\
\text { extended. }\end{array}$ & $\checkmark$ & & $k \pi$ \\
\hline 22 & Remove the 85 gallon drum from Port 203. & & $r$ & & $k / 2$ \\
\hline 23 & Remove the $0-30^{*} \mathrm{Hg}$ Vacuum Gauge installed on the Port 203 Vacuum sensing line. & $\begin{array}{l}\text { Verify that } 0-30^{*} \mathrm{Hg} \text { Vacuum Gauge } \\
\text { is removed. }\end{array}$ & 1 & & $k$ \\
\hline
\end{tabular}


HNF-SD-W026-ATR-021 Rev. 1

\begin{tabular}{|c|c|c|c|c|c|}
\hline Step & 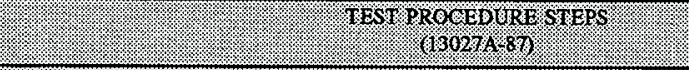 & 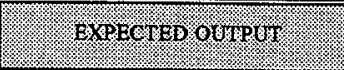 & (196\% & (1) & (nitialy \\
\hline \multicolumn{6}{|c|}{ 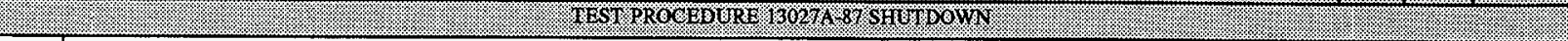 } \\
\hline 1 & Unforce all LCU 102 registers. & $\begin{array}{l}\text { Verify that all LCU registers are } \\
\text { unforced. }\end{array}$ & $\checkmark$ & & \\
\hline 2 & Return all glovebox and testing equipment items to a safe, secure position. & $\begin{array}{l}\text { Verify that all items used during } \\
\text { testing are returned to a safe, secure } \\
\text { position. }\end{array}$ & $\gamma$ & & \\
\hline \multicolumn{6}{|c|}{ 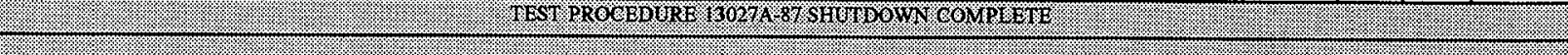 } \\
\hline & 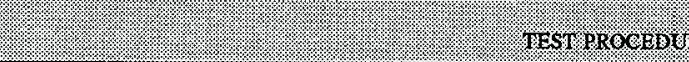 & & & & \\
\hline
\end{tabular}




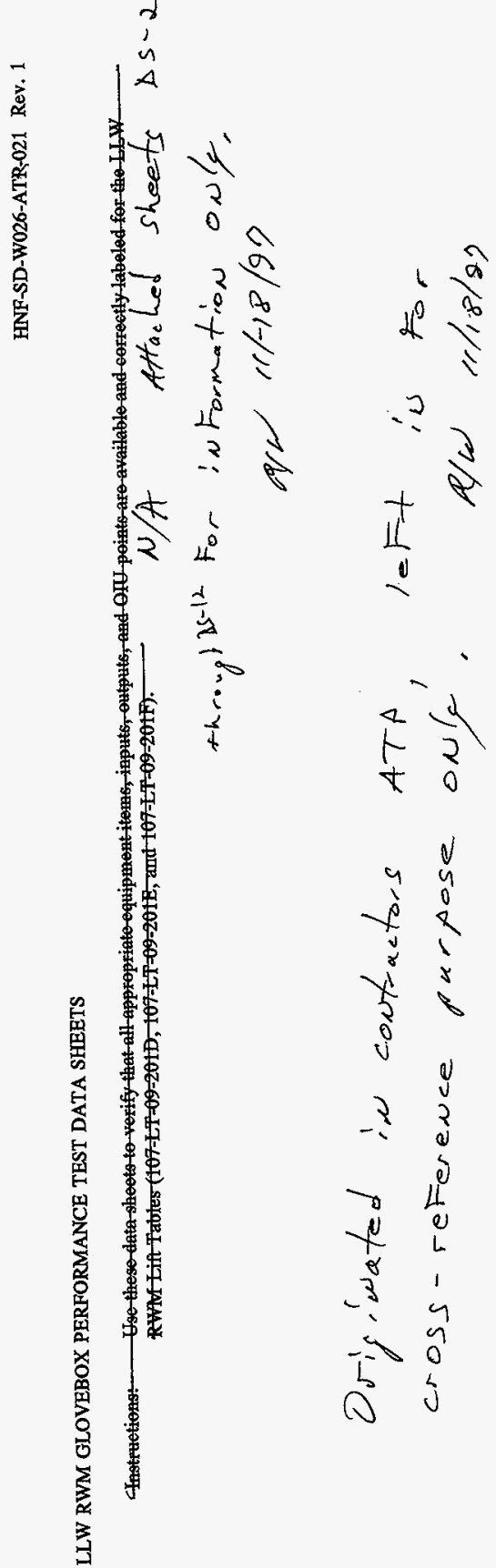




\section{LLW RWM LIFT TABLE CHECKOUT DATA SHEET \#1}

107-LT-09-201D (Port DO-07-203) LLW RWM DRUM LIFT TABLE

PROCEDURE: 13027A-87 TITLE: LLW RWM GLOVEBOX ACCEPTANCE TEST

\begin{tabular}{|c|c|c|c|c|c|}
\hline TAG ID & DESCRIPTION & Pes: & Fort: & Witines & \\
\hline \multicolumn{6}{|c|}{ 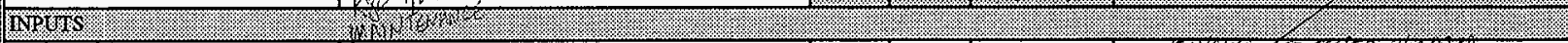 } \\
\hline 09-HS-227A & LOCALSOFF-NORMAL (L-O-R) SWITCH & & & & \multirow{14}{*}{ 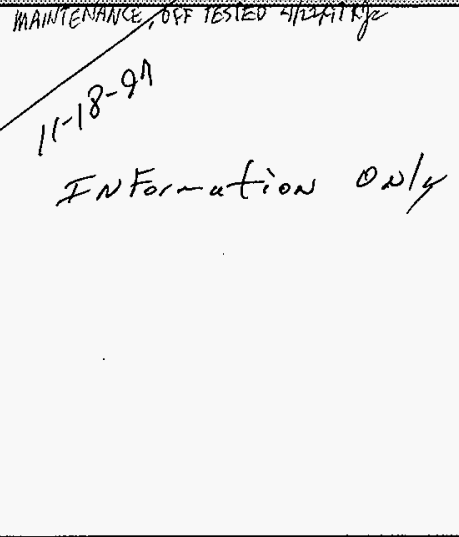 } \\
\hline 09-HS-227B/U & RAISE LIFT TABLE PUSHBUTTON & 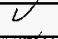 & & & \\
\hline 09-HS-227B/D & LOWER LIFT TABLE PUSHBUTTON & $\nu$ & & & \\
\hline 09-HS-227C/F & $\begin{array}{l}\text { ROLLER CONVEYOR FORWARD } \\
\text { PUSHBUTTON }\end{array}$ & & & & \\
\hline 09-HS-227C/R & $\begin{array}{l}\text { ROLLER CONVEYOR REVERSE } \\
\text { PUSHBUTTON }\end{array}$ & & & & \\
\hline 09-HS-227D & $\begin{array}{l}\text { AGV/PANEL SWITCH-LIFT TABLE LOCAL } \\
\text { CONTROL }\end{array}$ & & & & \\
\hline $09-Z S-227 \mathrm{~A}$ & AGV HANDSHAKE SIGNAL S1 & & & & \\
\hline $09-\mathrm{ZS}-227 \mathrm{~B}$ & AGV HANDSHAKE SIGNAL S2 (NOT USED) & & & & \\
\hline 09-ZS-227C & LIFT TABLE DOWN OVERTRAVEL & & & & \\
\hline 09-ZS-227D & LIFT TABLE UP OVERTRAVEL & & & & \\
\hline 09-ZS-227E & DRUM AT END OF CONVEYOR & & & & \\
\hline 09-ZS-227F & DRUM UNDER GLOVEBOX PORT/ & & & & \\
\hline $09-\mathrm{ZS}-227 \mathrm{G}$ & AGV MATING HEIGHT & & & & \\
\hline 09-XS-227A/B & ROPE SWTTCH A/B & & & & \\
\hline \multicolumn{6}{|c|}{ OHTWYS } \\
\hline $09-2 Y-227 \mathrm{~A}$ & AGV HANDSHAKE SIGNAL S1 & & & & \\
\hline $09-Z Y-227 B$ & AGV HANDSKAKKE SIGNAL S2 (NOT USED) & & & & \\
\hline 107-LT-09-201D/F & ROLLEB CONVEYOR FORWARD & & & & \\
\hline 107-LT-09-201D/R & ROJXER CONVEYOR REVERSE & & & & \\
\hline 107-LT-09-201D/RS & $\begin{array}{l}\text { ZTFT TABLE SERVO MOTOR CONTROLLER } \\
\text { COMMUNICATIONS INTERFACE (RS232C) }\end{array}$ & & & & \\
\hline 09-ZL-227D & DRUM IN POSITION & & & & \\
\hline \multicolumn{6}{|c|}{ 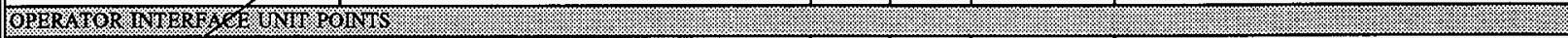 } \\
\hline STATUS & L-O-R SWITCH POSITION ( 1 = REMOTE) & & & & \\
\hline STATU ÚS & AGVLOCAL SWTTCH IN AGV & & & & \\
\hline STATUS & LIFT TABLE REQUIRES DRUM PICKUP & & & & \\
\hline STATUS & LIFT TABLE REQUIRES DRUM DROPOFF & & & & \\
\hline STATUS & $\begin{array}{l}\text { TRANSFER FROM LIFT TABLE TO AGV } \\
\text { COMPLETE }\end{array}$ & & & & \\
\hline
\end{tabular}


HNF-SD-W026-AF \& Rev. 1

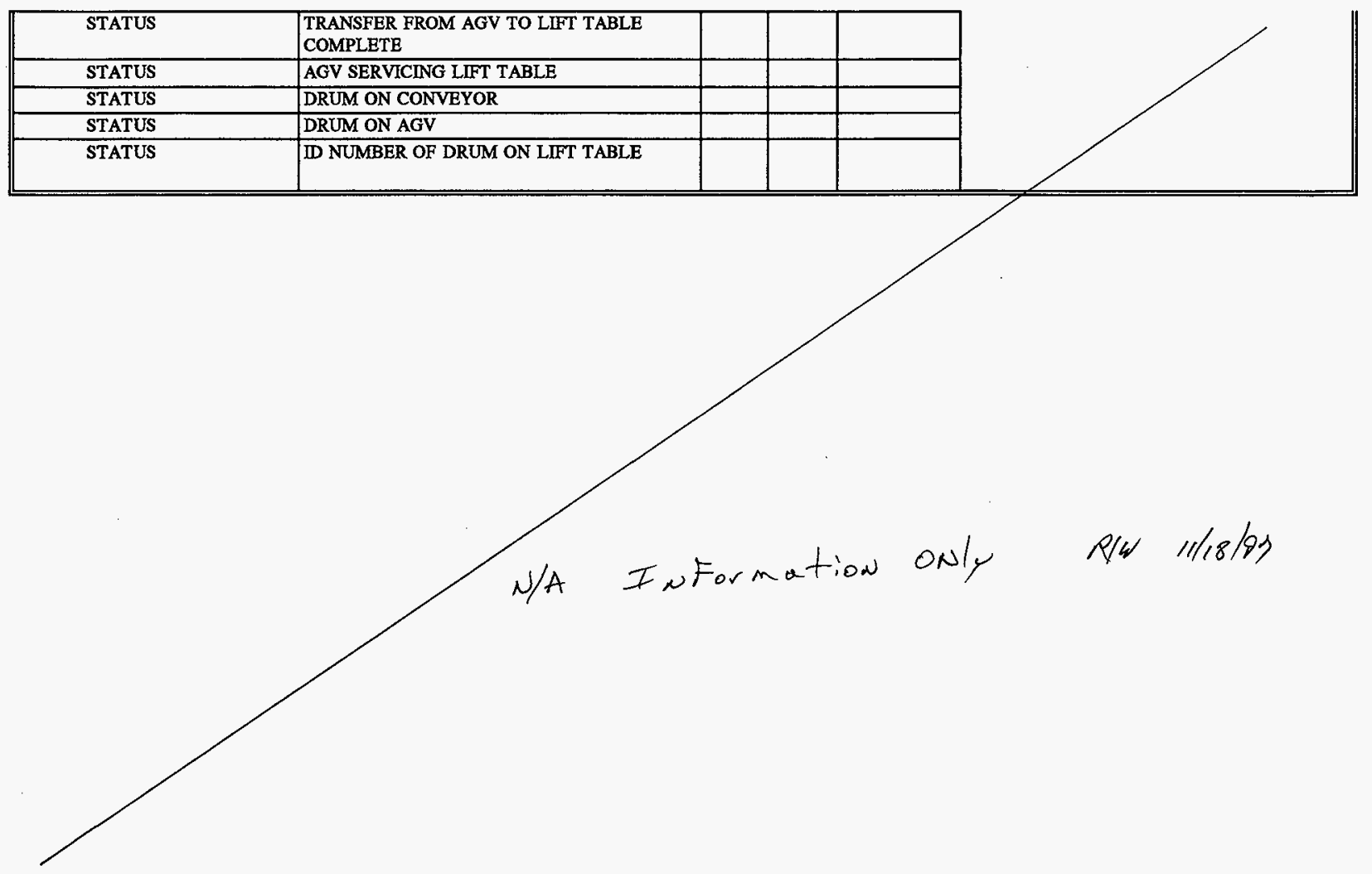

TEST PROCEDURE 13027A-87 SHUTDOWN

DS-3

LIW RWM Glovebox Acceptance Test 


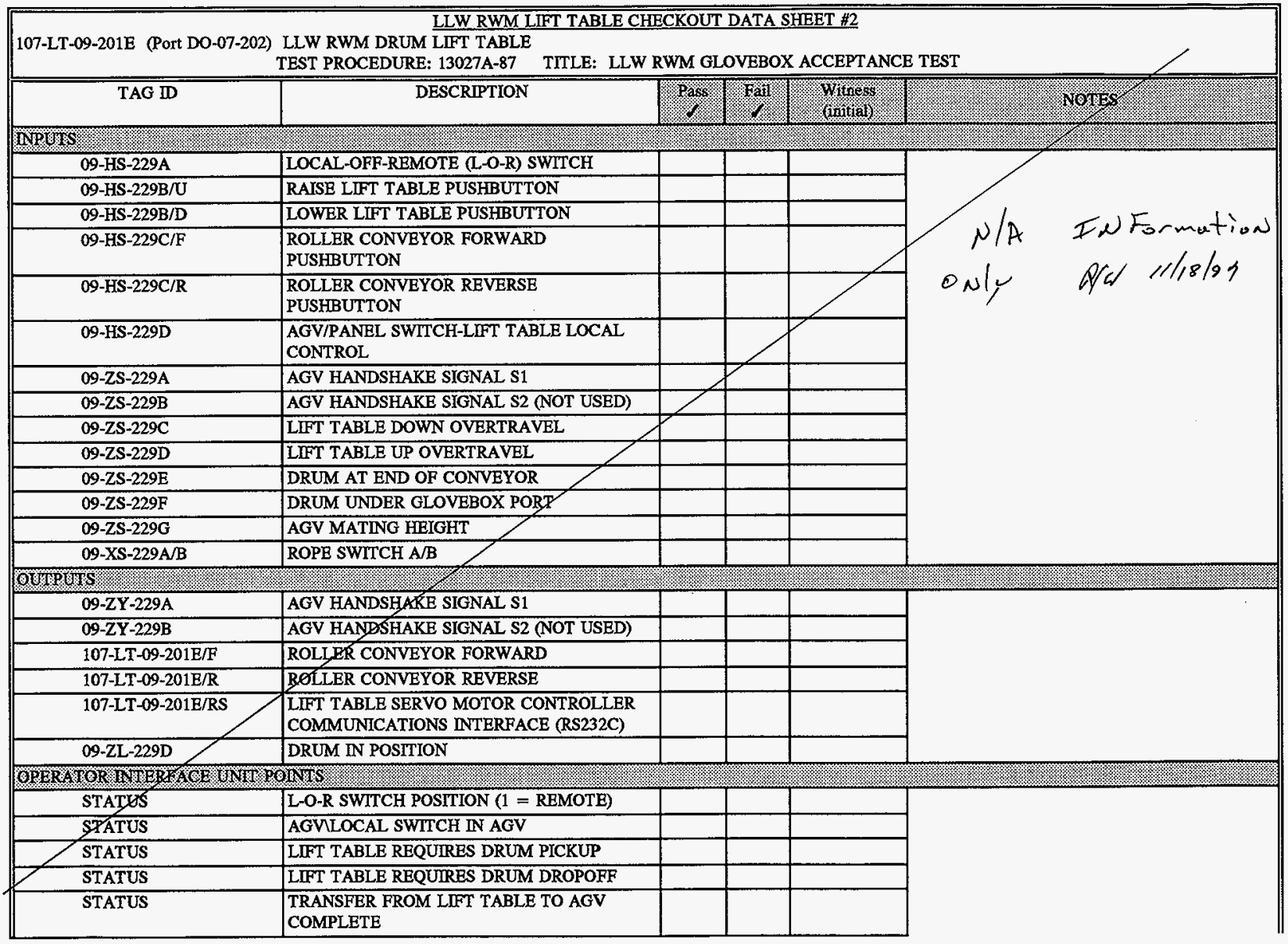


HNF-SD-W026-AR Rev. 1

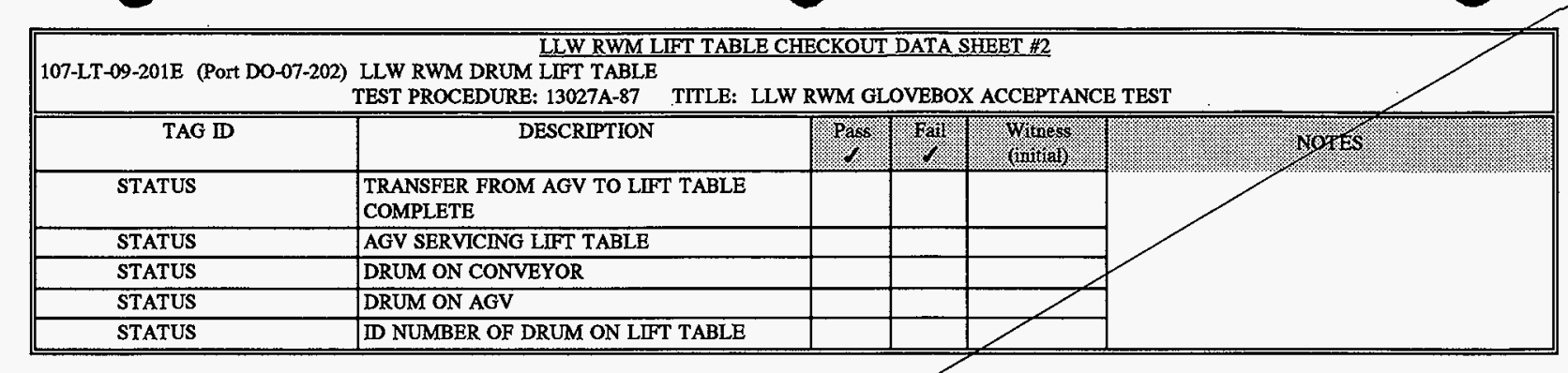




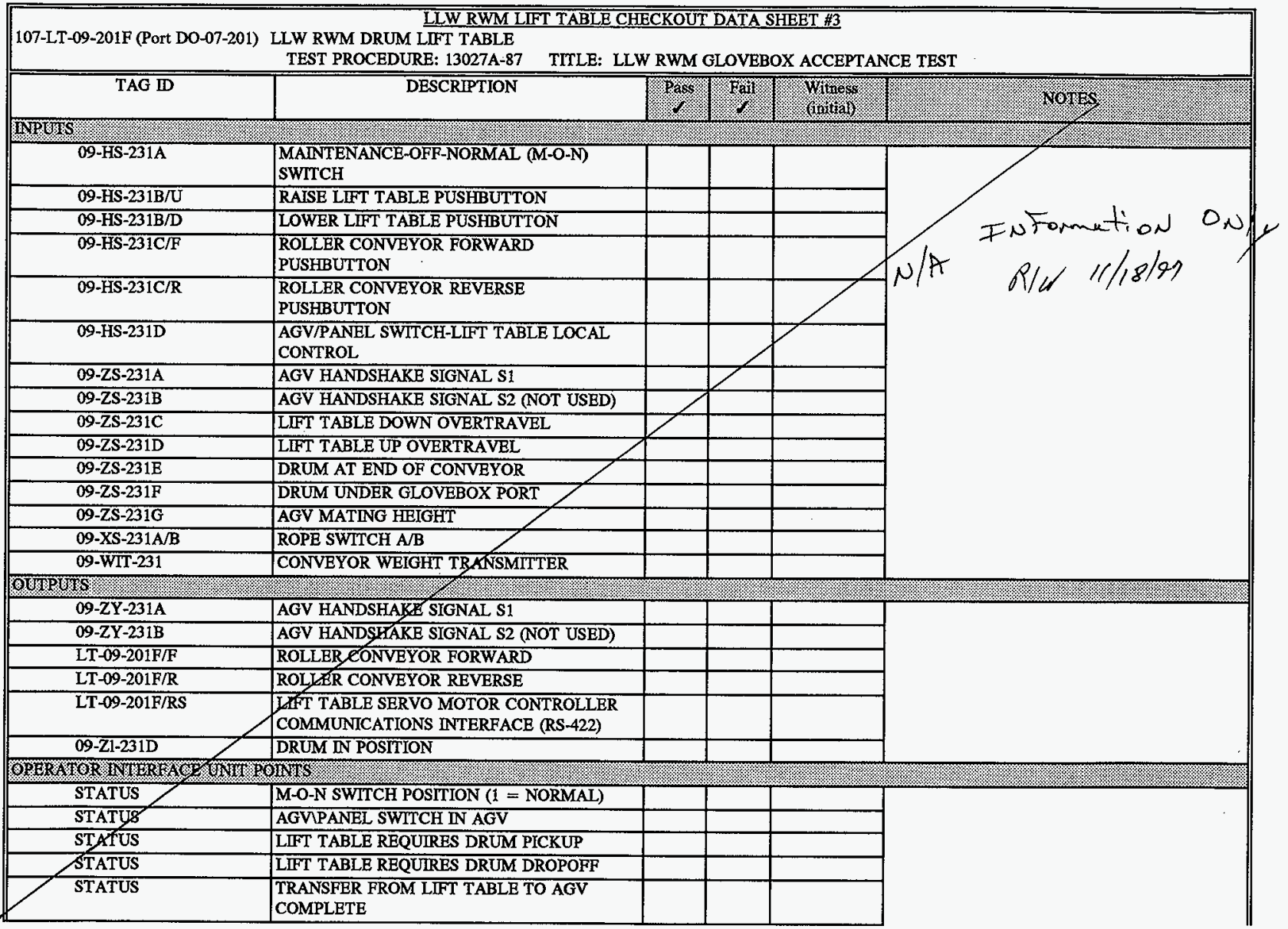




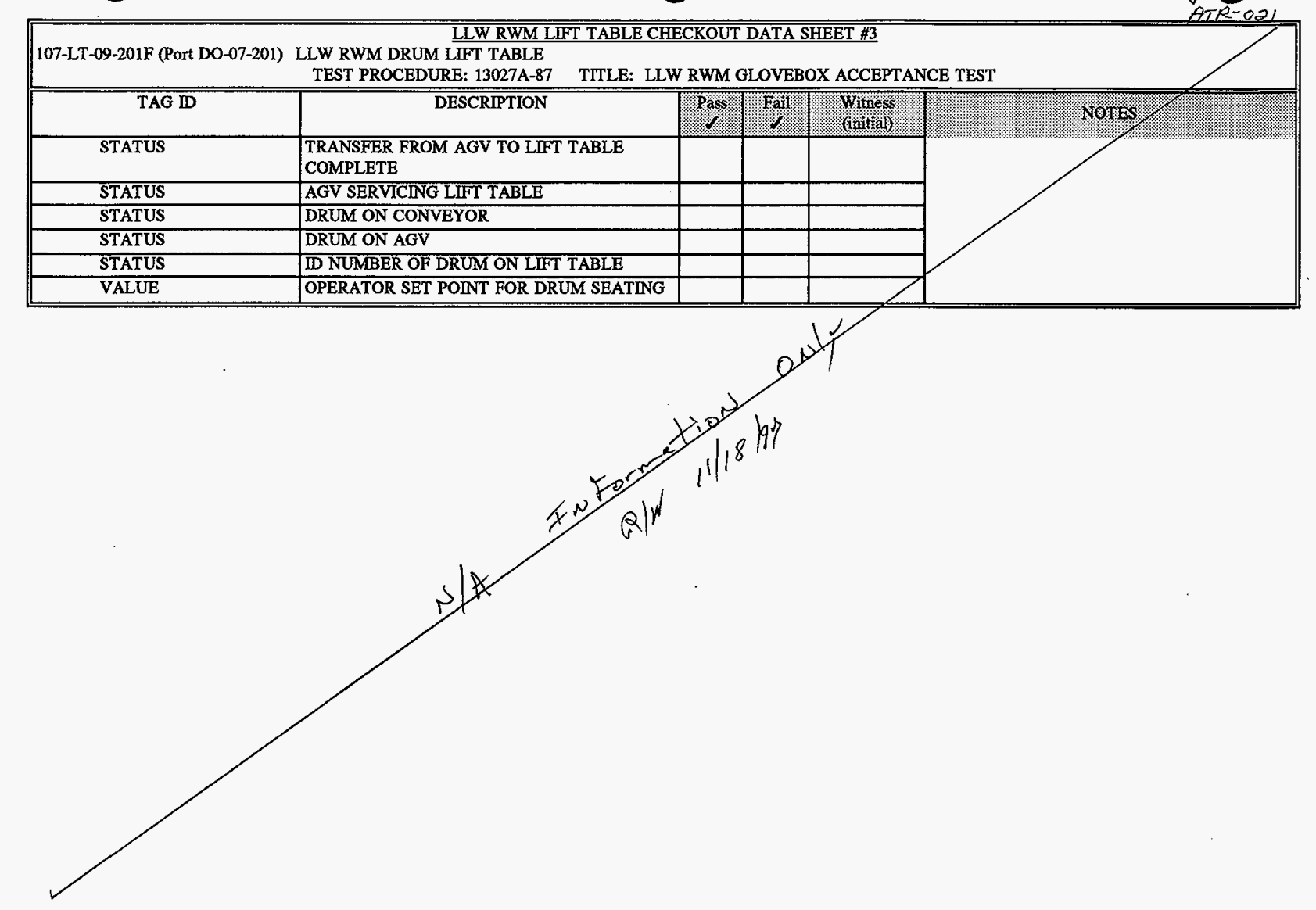




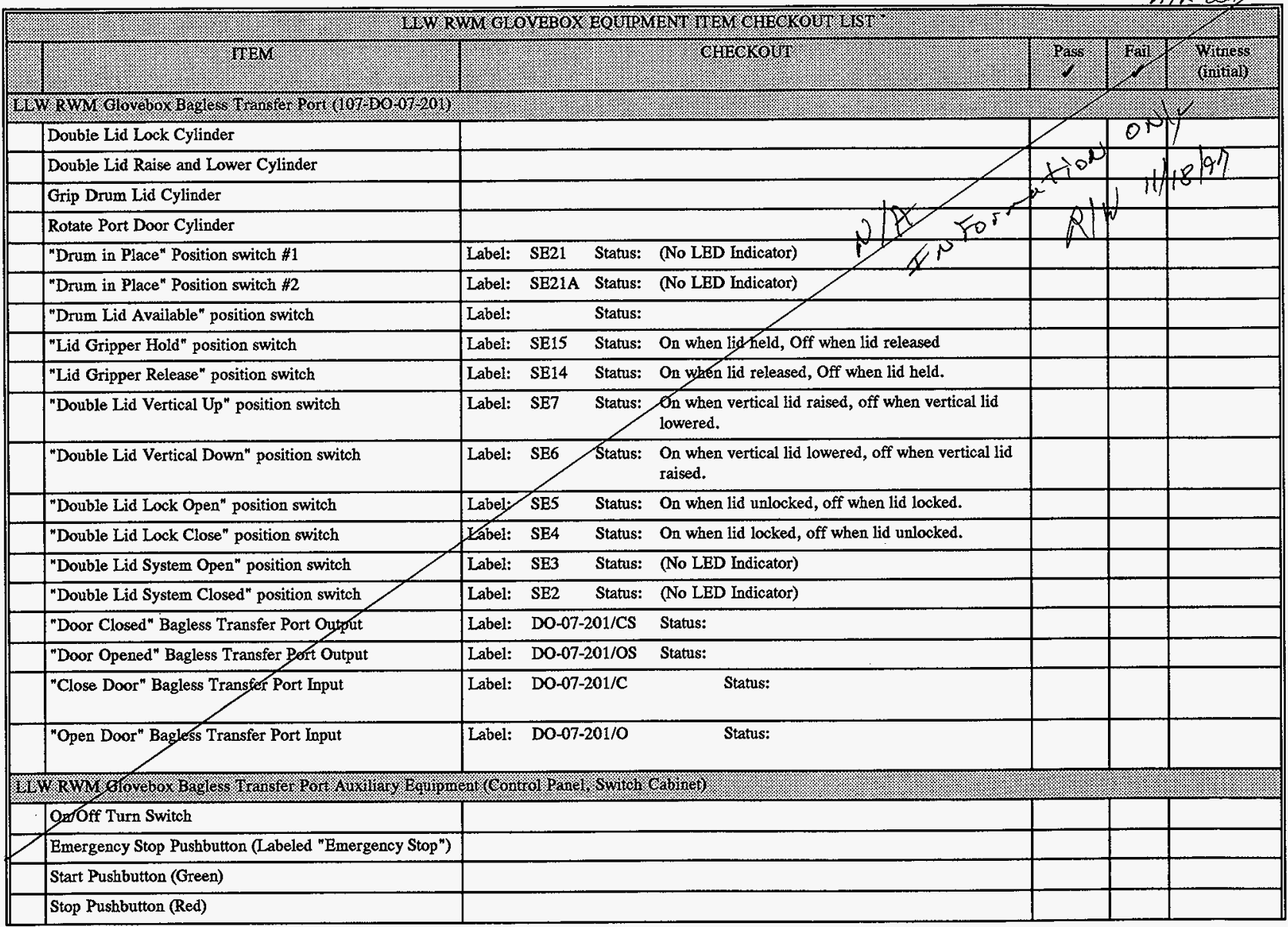




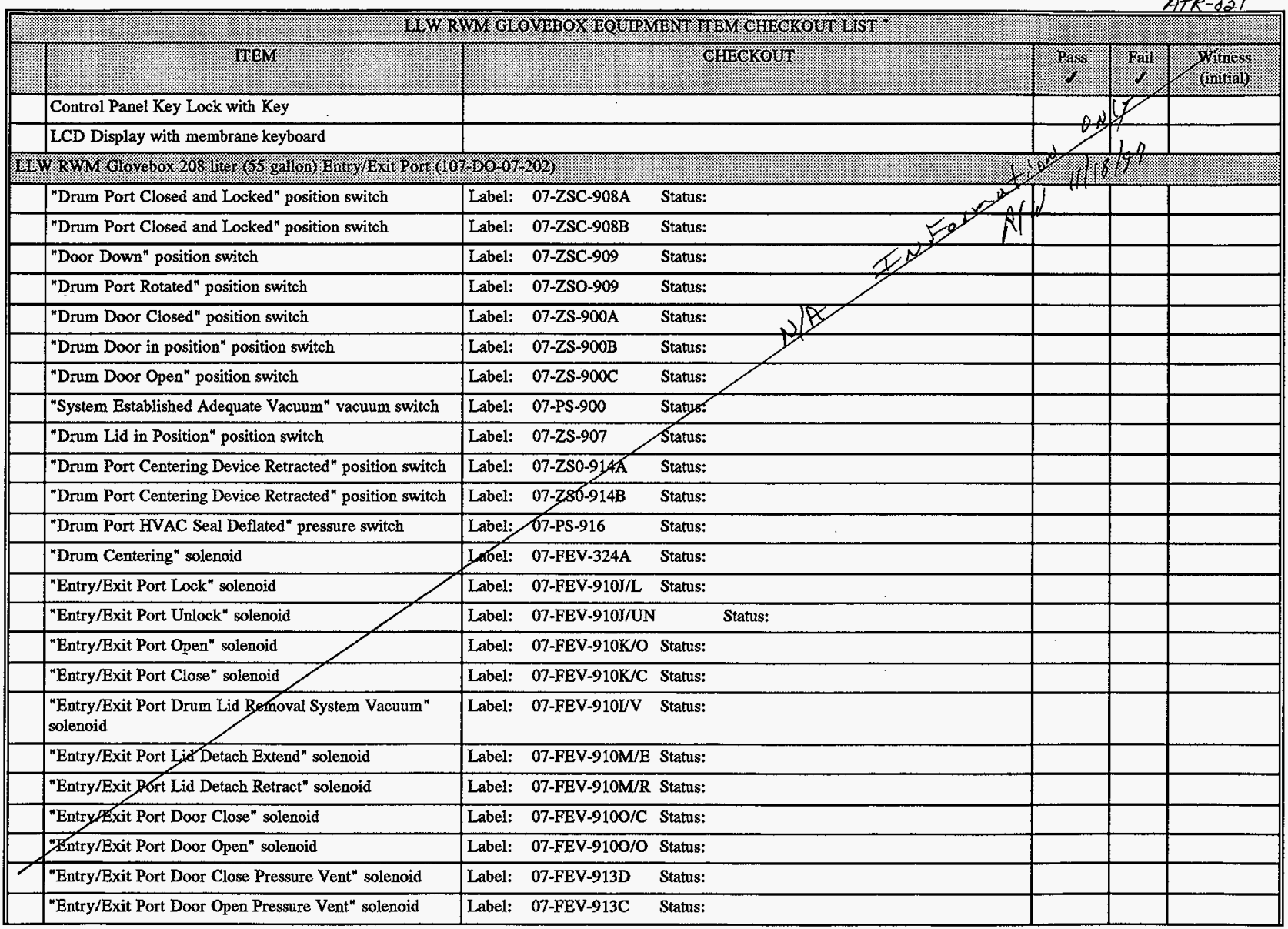




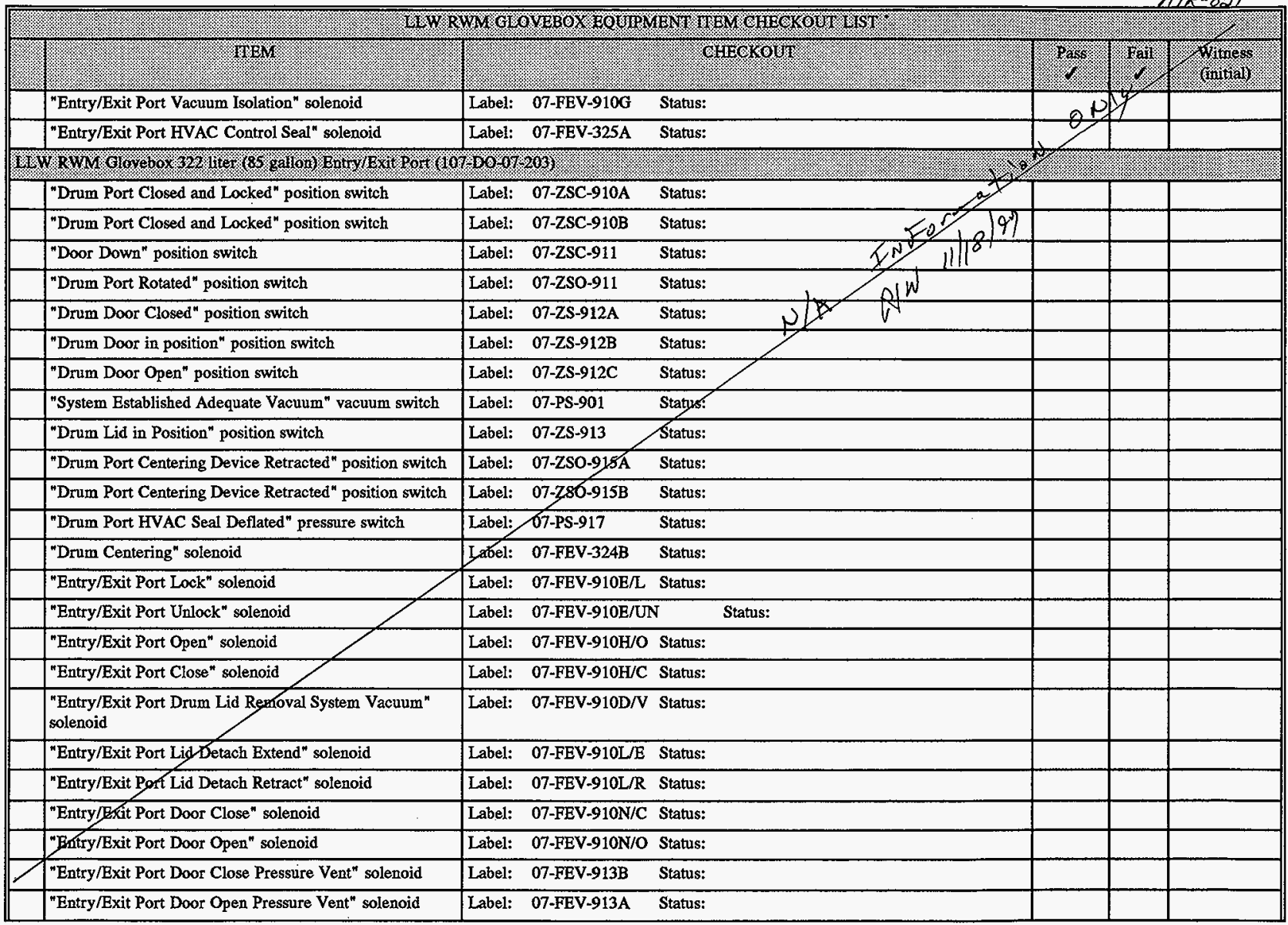




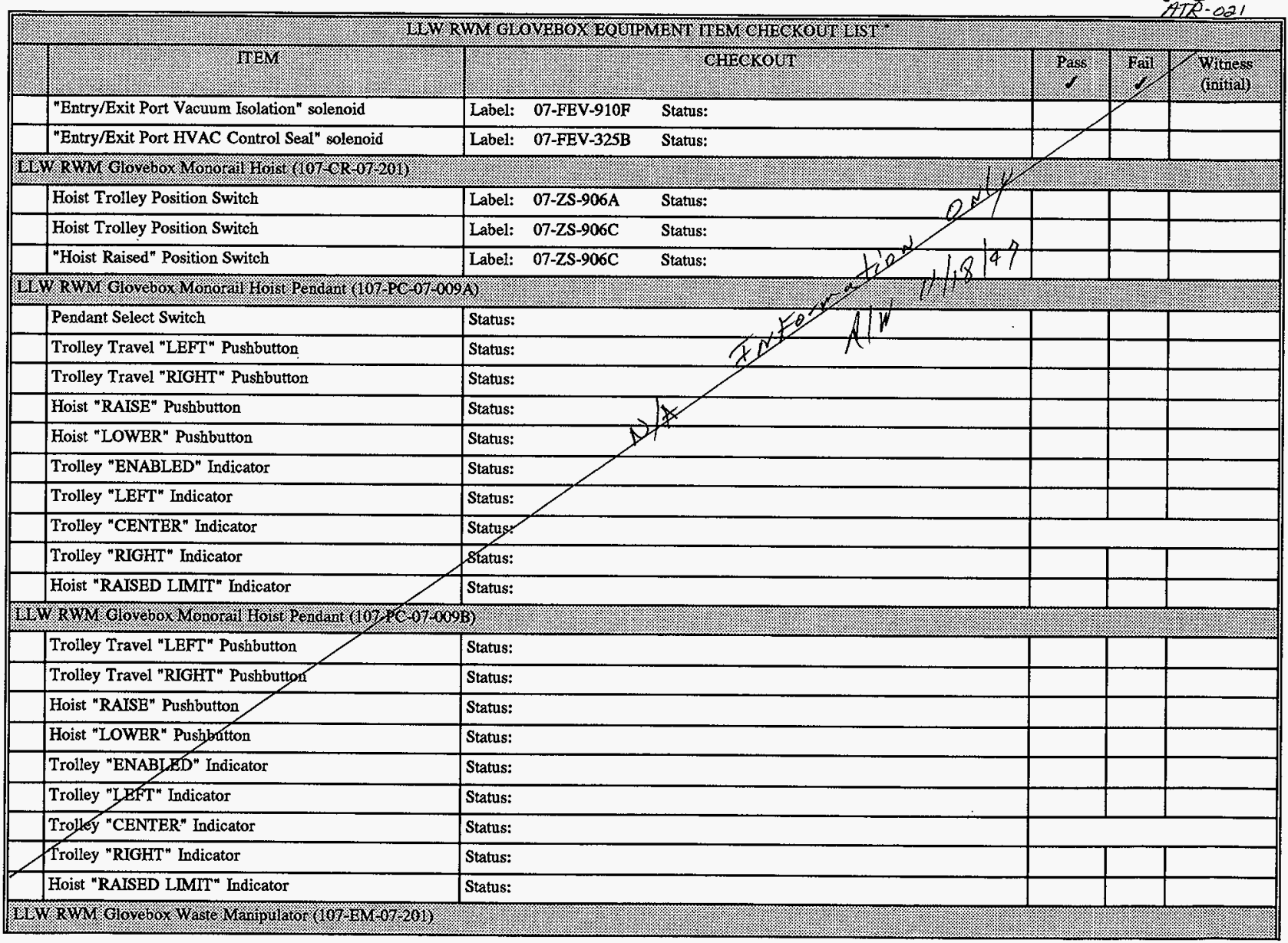




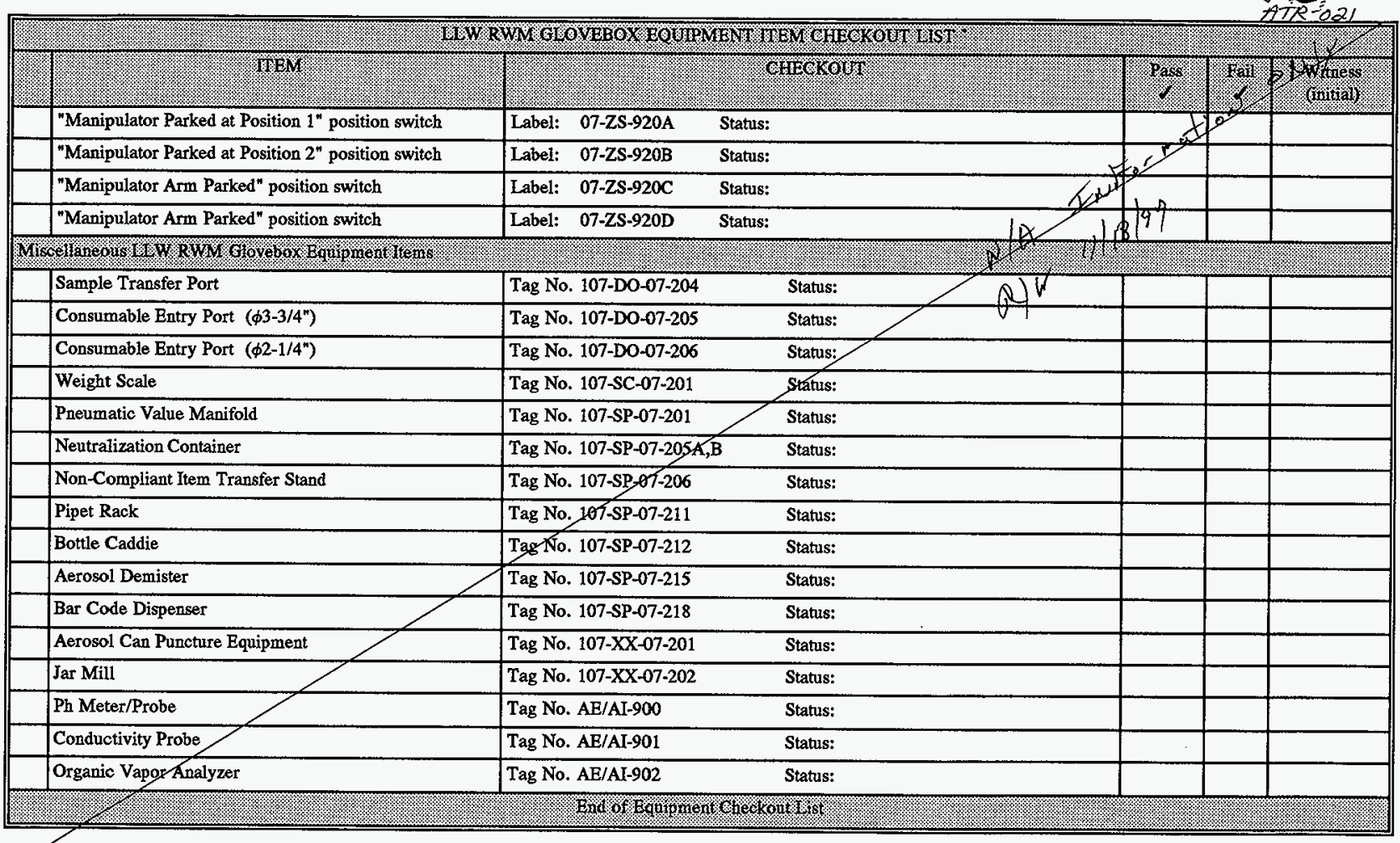




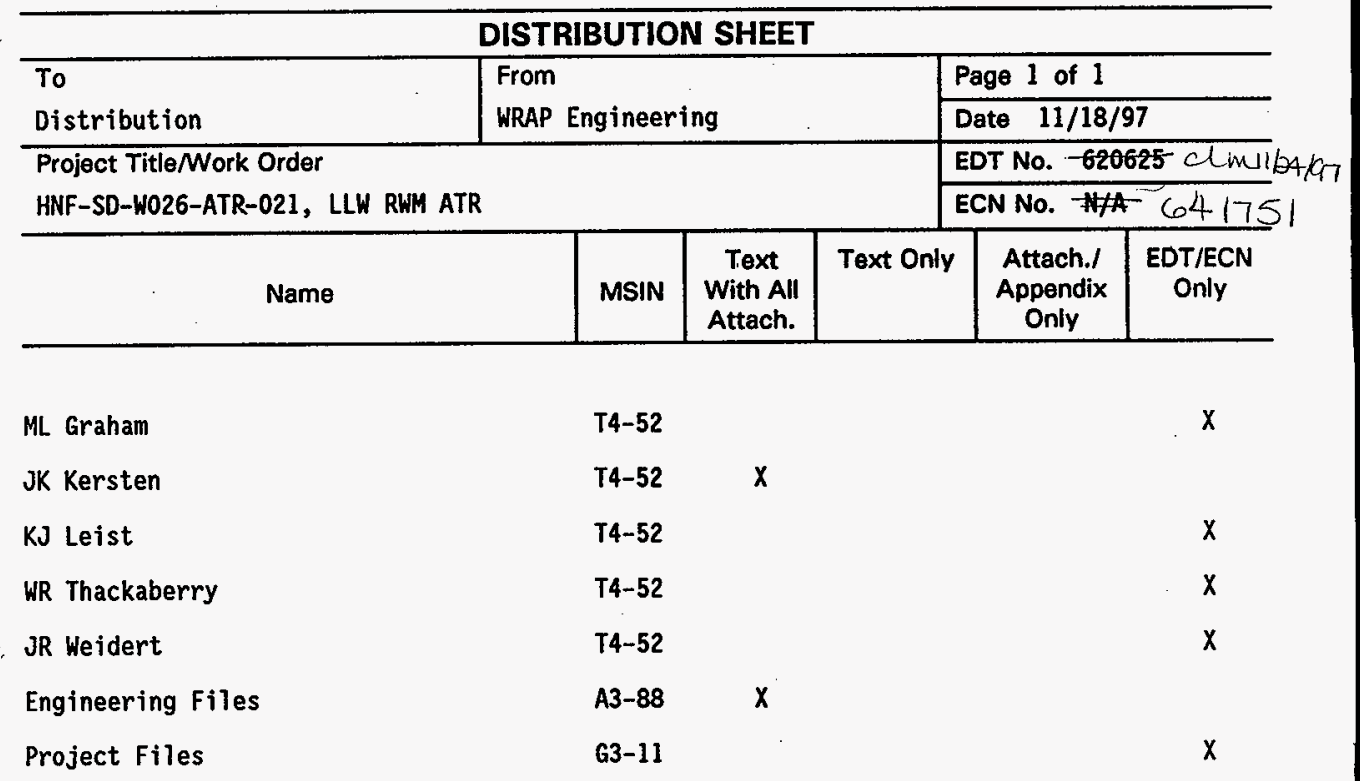

